Wilton Luiz Duque Lyra

\title{
INTERCOMUNICAÇÃO ENTRE MATEMÁTICA-CIÊNCIA-ARTE: UM ESTUDO SOBRE AS IMPLICAÇÕES DAS GEOMETRIAS NA PRODUÇÃO ARTÍSTICA DESDE O GÓTICO ATÉ O SURREALISMO
}

USP - São Paulo 


\section{Wilton Luiz Duque Lyra}

\section{INTERCOMUNICAÇÃO ENTRE MATEMÁTICA-CIÊNCIA-ARTE: UM ESTUDO SOBRE AS IMPLICAÇÕES DAS GEOMETRIAS NA PRODUÇÃO ARTÍSTICA DESDE O GÓTICO ATÉ O SURREALISMO}

Tese apresentada ao Programa de PósGraduação em Ciências da Comunicação; área de concentração: Interfaces Sociais da Comunicação da Escola de Comunicação e Artes da Universidade de São Paulo - USP, como exigência parcial para a obtenção do título de Doutor em Comunicação, sob a orientação do Prof. Dr. Artur Matuck.

USP - São Paulo 


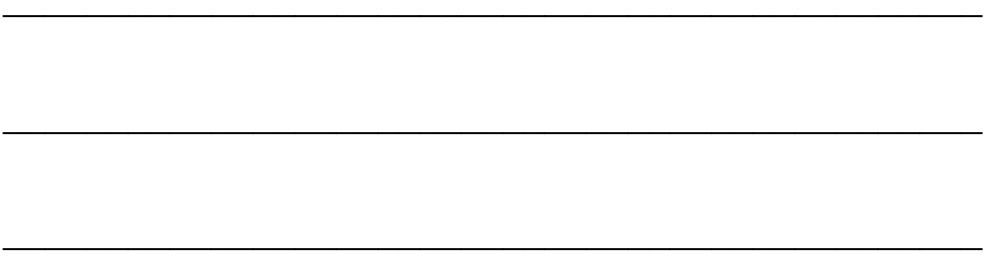


Dedico este trabalho às minhas filhas:

Bianca e Camila. 


\section{AGRADECIMENTOS}

Agradeço primeiramente ao Prof. Artur Matuck por ter me acolhido e orientado com tanto entusiasmo e dedicação.

Agradeço à Profa. Regina Machado, pois foi por intermédio dela que pude chegar aonde cheguei, à Pós-Graduação da Universidade de São Paulo.

Agradeço à minha esposa, Helenjane, por ter me dado apoio em todos os momentos difíceis. Sem sua ajuda, tomando conta de nossas duas filhas, Bianca de quatro anos e Camila de dois anos e sete meses, eu não poderia passar as madrugadas estudando e escrevendo.

Agradeço também à minha mãe, que sempre me incentivou a estudar, desde a época do ensino básico. 


\section{RESUMO}

Podemos dizer que as Catedrais Góticas, verdadeiras bíblias de pedra, são signos medievais que podem ser lidos já como o resultado da intercomunicação entre matemática-ciência-arte, uma vez que tais edificações surgiram de projeções arquitetônicas, da utilização de uma dada geometria assim como da execução de determinados conjuntos escultóricos.

Podemos ainda ressaltar que essa intercomunicação se intensifica durante todo o Renascimento, exemplo máximo da união entre esses três campos do conhecimento. No Renascimento, a geometria dominante é a Euclidiana; os artistas enfrentavam as questões espaciais a partir de um ponto de vista fixo. A história se transforma quando alguns matemáticos - por volta de 1800 - começam a pensar na possibilidade de outra geometria que não a de Euclides. Surge, então, um tipo de geometria que ficaria conhecida como geometria não-Euclidiana, uma geometria para ser utilizada em espaços curvos.

As implicações dessa nova Geometria foram tão abrangentes que influiu na elaboração da Teoria da Relatividade, de Einstein. Um novo tipo de intercomunicação entre matemática-ciência-arte, que ajudou a resolver questões ligadas a quadrimensionalidade. Enfim, trata-se de uma intercomunicação que influenciou na produção de artistas como Picasso, Duchamp e Dali.

Palavras-chave: Geometria Euclidiana, Geometria não-Euclidiana, Geometria Fractal, Terceira Dimensão, Quarta dimensão. 
We can say that the Gothic Cathedral, veritable Bibles of stone, are medieval sign that can be read as a result of the intercommunication among mathematicsscience-art, since that one buildings appear from an architectonic projection, from the utilization of a given geometry just as from the execution of a group of sculpture.

We can salient that this intercommunication intensifies during Renaissance, example maximum of the union among those three fields of knowledge. Into the Renaissance, the geometry dominant is the Euclidean, the artists faced the special questions from one fixed viewpoint. The story becomes different when some mathematicians - around 1800 - begin thinking on the possibility of another geometry that doesn't that of Euclid's. Appears, then, a kind of geometry that would be known as non-Euclidean Geometry: a geometry to be used in curved space.

The implications of that new Geometry was so in-depth that influenced the elaboration of Einstein's Relativity Theory. Therefore a new kind of intercommunication among mathematics-science-art, which it helped to resolve questions linked together to the fourth dimension. An intercommunication that influenced the production of artists like Picasso, Duchamp and Dali.

key words: Euclidean Geometry, non-Euclidean Geometry, Fractal Geometry, ThirdDimension, Fourth-Dimension. 



\section{INTRODUÇÃO}

Os chamados povos primitivos transformavam elementos naturais em pigmentos para representar animais nas cavernas, pois acreditavam que tal representação traria benefícios no momento da caça. Se por um lado o misticismo permeou todas as manifestações artísticas na pré-história, há um outro elemento que poderíamos ressaltar: a transformação de elementos naturais para produzir tinta. Evidentemente que tal atividade não é um exemplo de produção científica, entretanto, pode ser, no mínimo, um exemplo de intercomunicação entre determinadas manifestações artísticas e a transformação de matérias. Com o passar dos tempos essa intercomunicação foi se desenvolvendo de modo mais complexo.

A utilização da Geometria na antiguidade estava restrita a medir a terra. Ela surgiu de experimentações, observações e analogias, e especialmente de uma série de descobertas empíricas cujas respostas aproximadas eram suficientes para propósitos práticos. O primeiro esforço de sistematização se iniciou pelas mãos de Tales de Mileto e foi continuado por Pitágoras. Euclides, no entanto, foi quem sistematizou definitivamente, por volta de 300 a.C., todos os elementos da geometria. A chamada Geometria Euclidiana foi durante muito tempo a mais importante e a única geometria aceitável por todos. Porém, rigorosamente falando, a importância de Euclides deve ser reconhecida porque foi ele quem reuniu as principais idéias acerca da geometria em um livro-texto chamado Os elementos.

O postulado que acabou intrigando muitos estudiosos foi o postulado das retas paralelas: retas que estando no mesmo plano, e prolongadas em ambas as direções, não se encontram em ponto algum. O problema de tal postulado é que não há como verificar se duas retas paralelas, de fato, não se encontrariam, pois por mais que as prolonguemos cada vez mais longe, não poderíamos fazê-lo infinitamente. Em meados do século XIX, dois matemáticos, que buscavam soluções alternativas ao problema das retas paralelas, acabaram por desenvolver uma nova formulação geométrica, surgiria então a Geometria não-Euclidiana.

A descoberta da geometria não-Euclidiana se iniciou quase simultaneamente pelas mãos de dois jovens e eminentes matemáticos: János Bolyai e Nicolai Lobachevsky. Uma das implicações dessas descobertas é que um novo conceito deveria se incorporado ao estudo da geometria: reta geodésica de um espaço 
modelo. Trata-se de um espaço em que apenas a geometria não-Euclidiana funciona.

Gauss, uma outra personagem importante nesse cenário, afirmava que a mera possibilidade da soma dos ângulos internos de um triângulo ser menor do que $180^{\circ}$ já conduziria a uma geometria curiosa, bem diferente da que ainda estamos acostumados no dia-a-dia. A geometria não-Euclidiana desmonta uma das proposições de Kant, ou seja, a de que o espaço euclidiano é inerente à estrutura de nossa mente (Greenberg: 1994, p. 182).

A Geometria não-Euclidiana gerou muitos desdobramentos, porém a maioria das pessoas não se deu conta de seu impacto e da revolução que esta gerou. Para termos uma idéia, observe-se que, segundo Marcelo Gleiser, foi só após Einstein dominar as sutilezas da geometria não-euclidiana que ele obteve as equações da relatividade geral em sua forma definitiva. Enfim, se alguém quiser entender minimamente o significado da equação que mudou o mundo deveria estudar, primeiro, a geometria não-euclidiana.

A teoria da relatividade é melhor compreendida a partir da geometria nãoeuclidiana tomando como dado a curvatura do espaço causada pela força gravitacional. Na concepção eisteiniana a força da gravidade desaparece e é substituída pela geometria do próprio espaço: a matéria curva o espaço, e o que chamamos de gravitação é apenas a aceleração dos objetos ao deslizarem pelo "tobogã" descrito pelas suas trajetórias no tempo, através das ondulações do espaço. Ora, se a partir de um postulado, que teoricamente não poderia ser comprovado, surgiu uma nova geometria que teve implicações até na Teoria da Relatividade, como foi esse impacto em algumas manifestações artísticas? Como essa nova formulação exerceu influência sobre a produção estética? Como a geometria euclidiana foi gradualmente afetando outros campos do conhecimento? Podemos dizer que nas artes plásticas houve uma divisão entre produções Euclidianas e não-Euclidianas?

O objetivo inicial deste estudo de doutorado foi compreender os postulados básicos da geometria de Euclides para em seguida entender a complexidade de uma geometria que confrontava estes mesmo postulados; e em segundo lugar, o propósito foi analisar um exemplo de migração interdisciplinar avaliando implicações destes dois paradigmas em uma série de obras artísticas. 
Para tanto, começamos traçando um panorama histórico desde Pitágoras, Tales de Mileto, Euclides e seus postulados até por volta de 1800, quando surgem as primeiras investigações sobre a Geometria não-Euclidiana.

Nas Catedrais Góticas, por exemplo, investigamos como a Geometria de Euclides foi utilizada, ou seja, qual foi sua contribuição nessas construções. É observando as janelas das catedrais que percebemos com clareza a utilização da geometria Euclidiana: janelas fortemente marcadas pela simetria, que ajudam a reforçar a concepção metafísica da Idade Média.

Nas catedrais Góticas estudamos também a geometria utilizada na construção das Rosáceas, elemento arquitetonico ornamental muito usado no século XIV. Com cores fortes, acentuando o realismo da representação, elas potencializam o contato com a espiritualidade e a ascensão do sagrado. A decoração é feita no sentido radial, estilizando a representação das pétalas de uma rosa; está ligada à história bíblica de uma figura que surge no centro da composição. Os temas mais retratados são Virgem com o Menino, cenas da vida de Cristo e dos apóstolos e as mais variadas histórias bíblicas.

Se na Idade Média a Geometria Euclidiana foi utilizada basicamente nas Catedrais, no Renascimento sua utilização se deu com muito mais intensidade no campo da pintura, num período em que a visão física aos poucos substituiu a visão espiritual, ou seja, em um período em que o olho interior da alma foi substituído como o órgão básico da visão artística. No Renascimento a Geometria Euclidiana foi utilizada para criar o efeito de profundidade através da perspectiva. $E$ os artistas estudados foram Piero della Francesca e Leonardo Da Vinci porque os dois escreveram tratados voltados à geometria.

Até meados de 1912 a geometria Euclidiana e a tridimensionalidade eram suficientes, segundo as observações de Henderson, para aplacar o anseio dos artistas no que diz respeito ao infinito. Com o surgimento da geometria nãoEuclidiana novas preocupações espaciais foram introduzidas, mas que não mais poderiam ser resolvidas a partir da relação entre altura, largura e comprimento de um dado objeto. Passou a ser necessário uma dimensão adicional, uma quarta dimensão que representasse o espaço eternalizado em todas as direções em um dado momento. E para analisarmos esse período, escolhemos três representantes da arte moderna que sofreram influência direta das descobertas da 
quadrimensionalidade. São eles: Picasso, Duchamp e Dali. Verificamos como cada um deles enfrentou as questões da quarta dimensão.

A Geometria não-Euclidiana contestou os princípios da Geometria Euclidiana basicamente devido a um de seus postulados, o postulado das retas paralelas. Com a Geometria Fractal não houve de fato um embate! Para estudarmos a constituição do nosso mundo, dos oceanos, das montanhas e rios, rochas, plantas e animais etc., a Geometria Euclidiana mostrou-se insuficiente; e a geometria não-Euclidiana não apresentou elementos teóricos adequados a tal análise porque formas irregulares demandam uma outra modalidade de Geometria.

Um aspecto que vale a pena ressaltar é a importância do computador no desenvolvimento da geometria fractal. A importância está no fato de que os cientistas e matemáticos descobriram que poderiam gerar formas fractais em seus próprios computadores a partir de softerwares específicos. Os computadores, com sua rapidez para fazer cálculos, permite a criação de imagens a partir de algoritmos.

Apresentamos um estudo sobre as possíveis relações matemáticas utilizadas por Piero della Francesca nos afresco Exaltação da Cruz - Heráclio que leva a verdadeira cruz a Jerusalém. Tratas-se de um exercício que pressupõe três fases de desenvolvimento: um momento antes da leitura, um momento durante da leitura e um momento depois da leitura. Esse exercício é chamado de Seqüência Didática e faz parte do Referencial de expectativas para o desenvolvimento da competência leitora e escritora no ciclo II do ensino fundamental. 


\section{SUMÁRIO}

GEOMETRIA EUCLIDIANA E_NÃO-EUCLIDIANA ................................................. 14

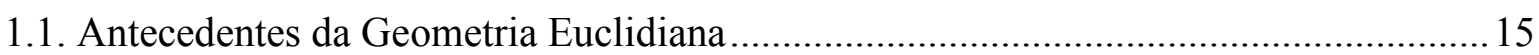

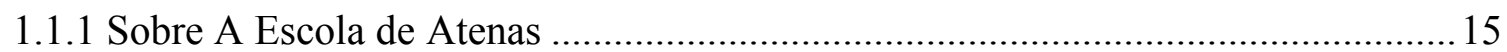

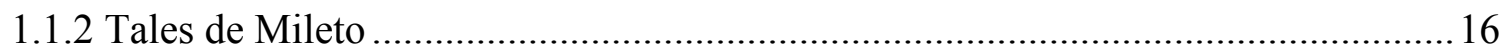

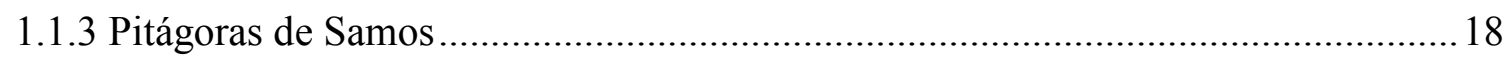

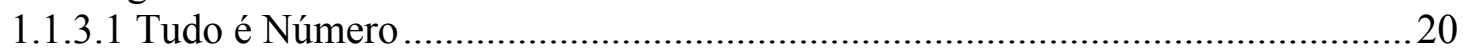

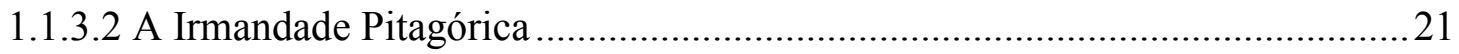

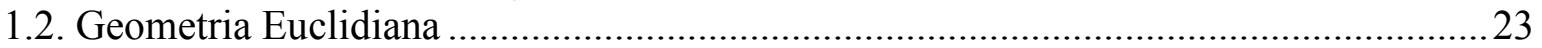

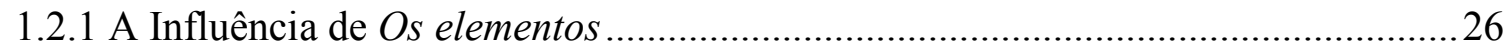

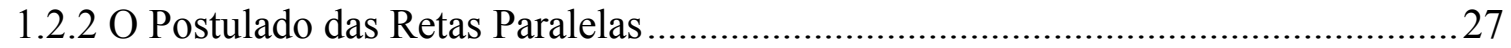

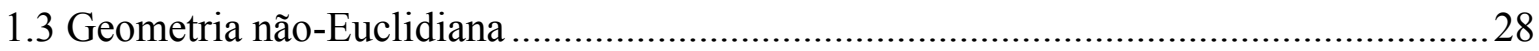

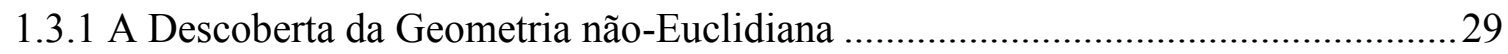

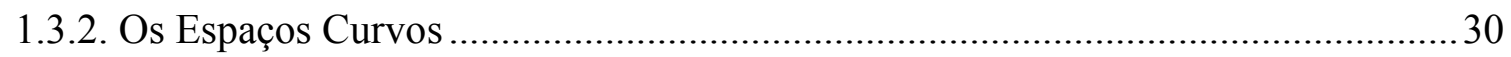

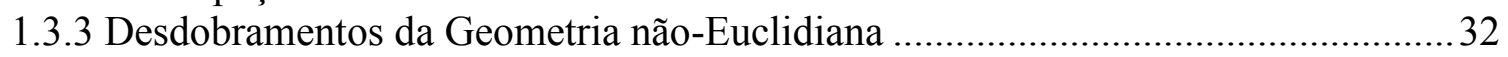

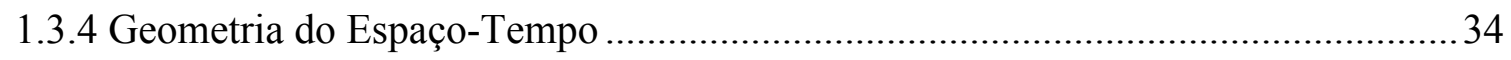

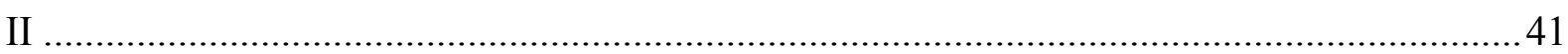

A GEOMETRIA EUCLIDIANA NAS CATEDRAIS GÓTICAS_E NA PINTURA DO

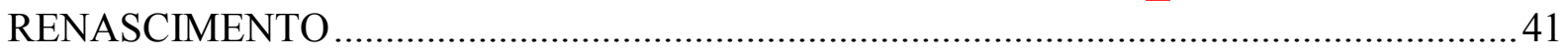

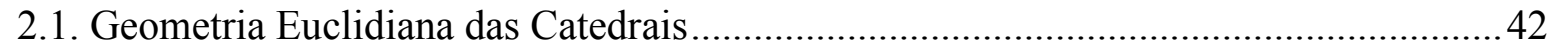

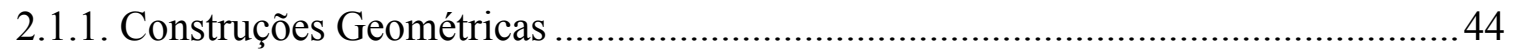

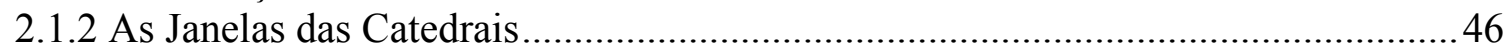

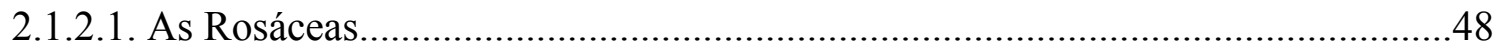

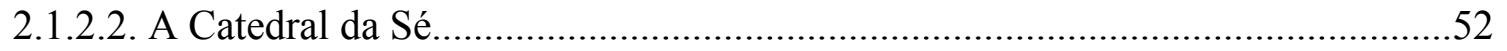

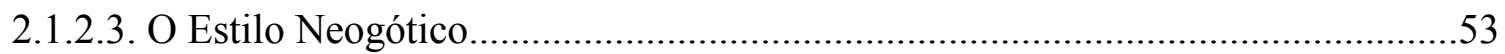

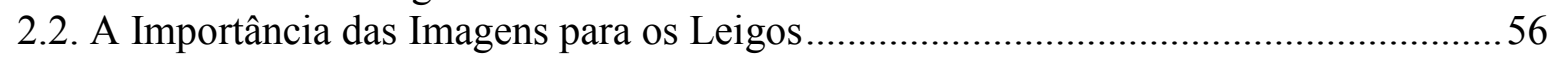

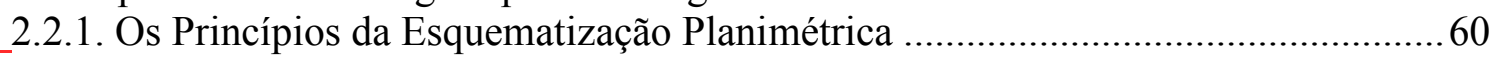

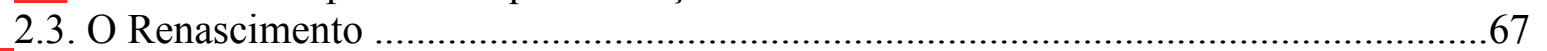

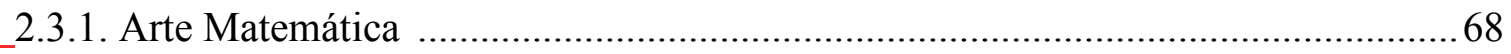

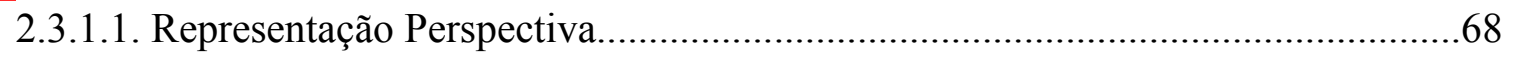

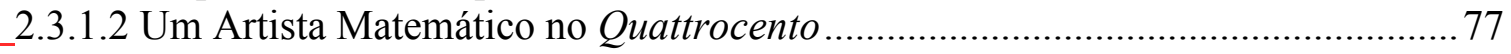

2.3.1.2.1. Piero della Francesca e Geometria Euclidiana...............................................79

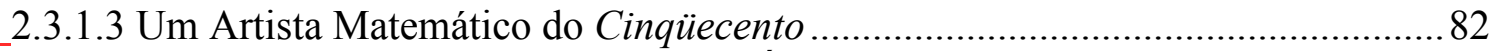

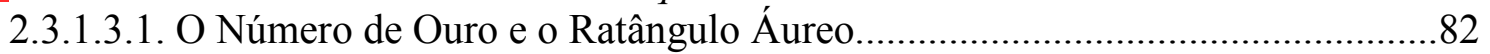

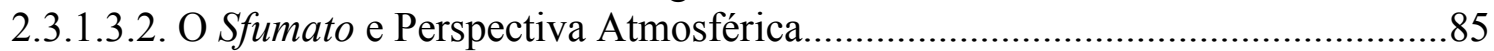

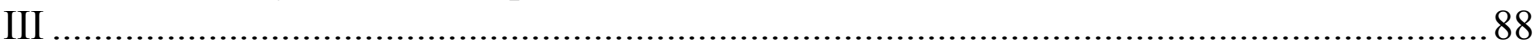

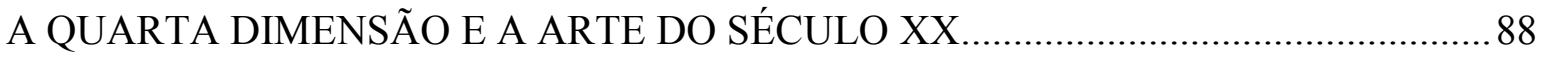

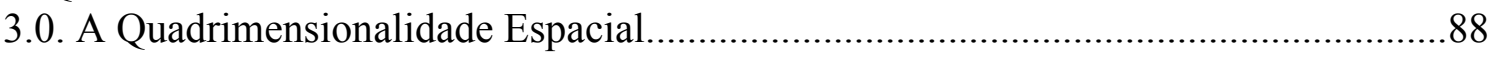

3.0.1. Cubismo e a Quadrimensionalide Espacial ..................................................... 90

3.0.2. Marcel Duchamp e Quadrimensinalidade Espacial.............................................93

3.0.3. Salvador Dali e a Quadrimensionalidade Espacial............................................99

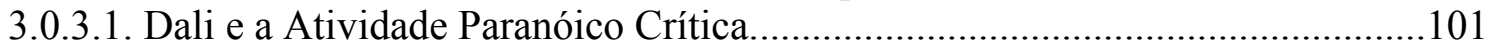

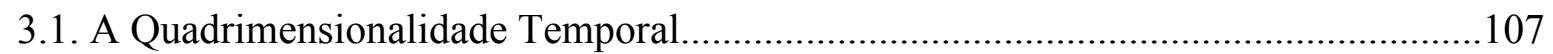


IV

1111

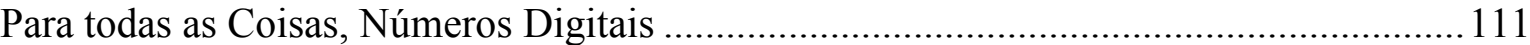

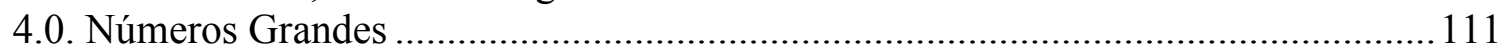

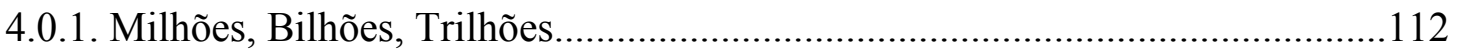

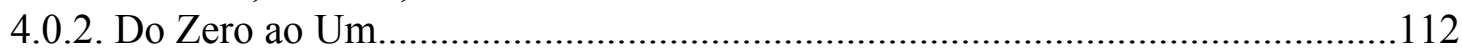

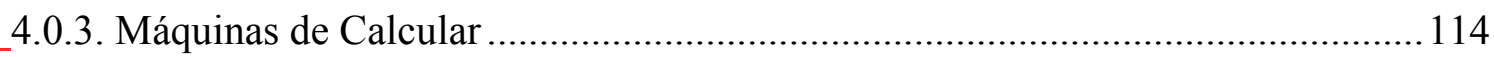

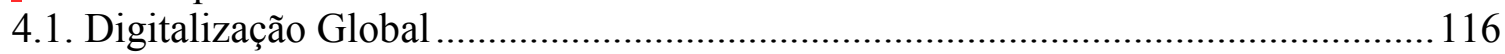

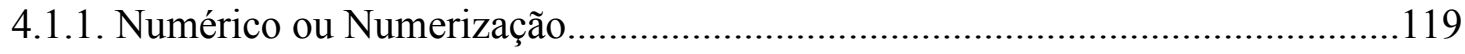

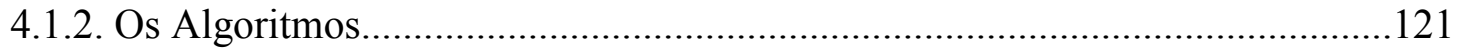

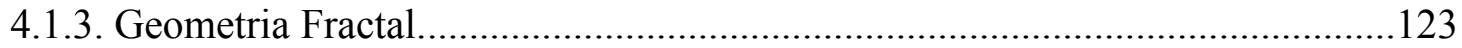

V

Leitura de Imagem a partir da Geometria Euclidiana.........................................130

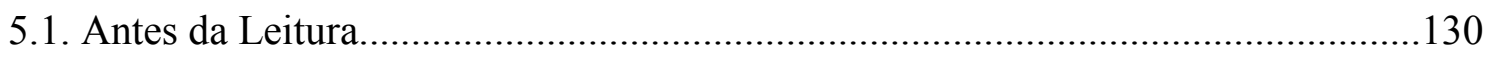

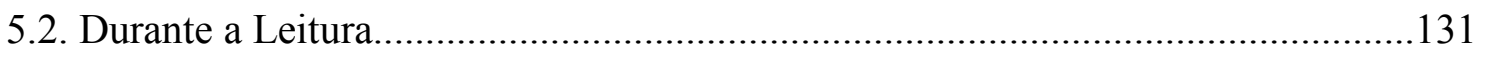

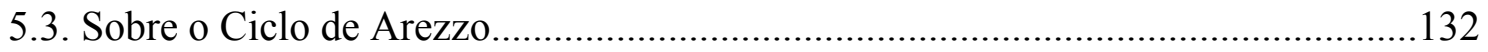

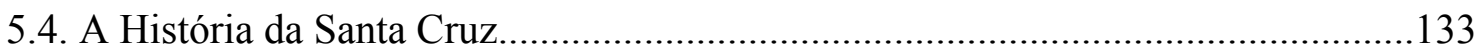

5.4.1. Seqüência do Ciclo de Afrescos da Capela Maior de São Francisco de

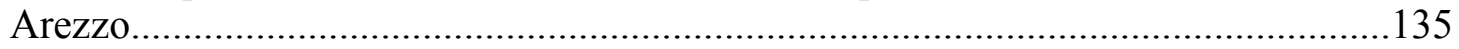

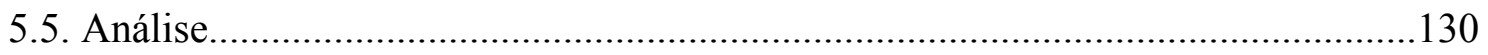

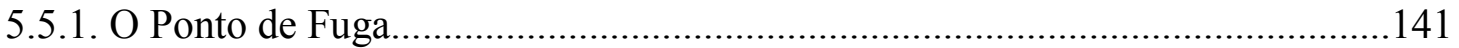

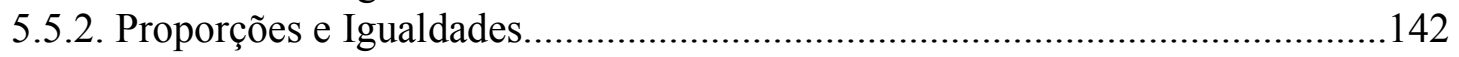

5.5.3. Média Proporcional de dois Segmentos........................................................145

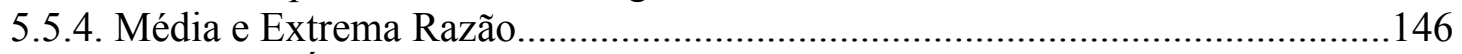

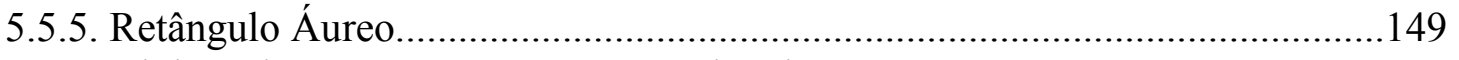

5.5.6. Divisão de um Segmento em partes iguais.......................................................151

VI.

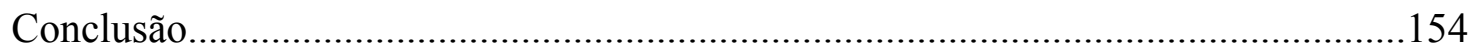

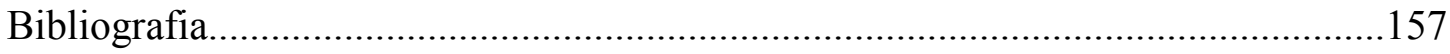




\section{I}

\section{GEOMETRIA EUCLIDIANA E}

\section{NÃO-EUCLIDIANA}

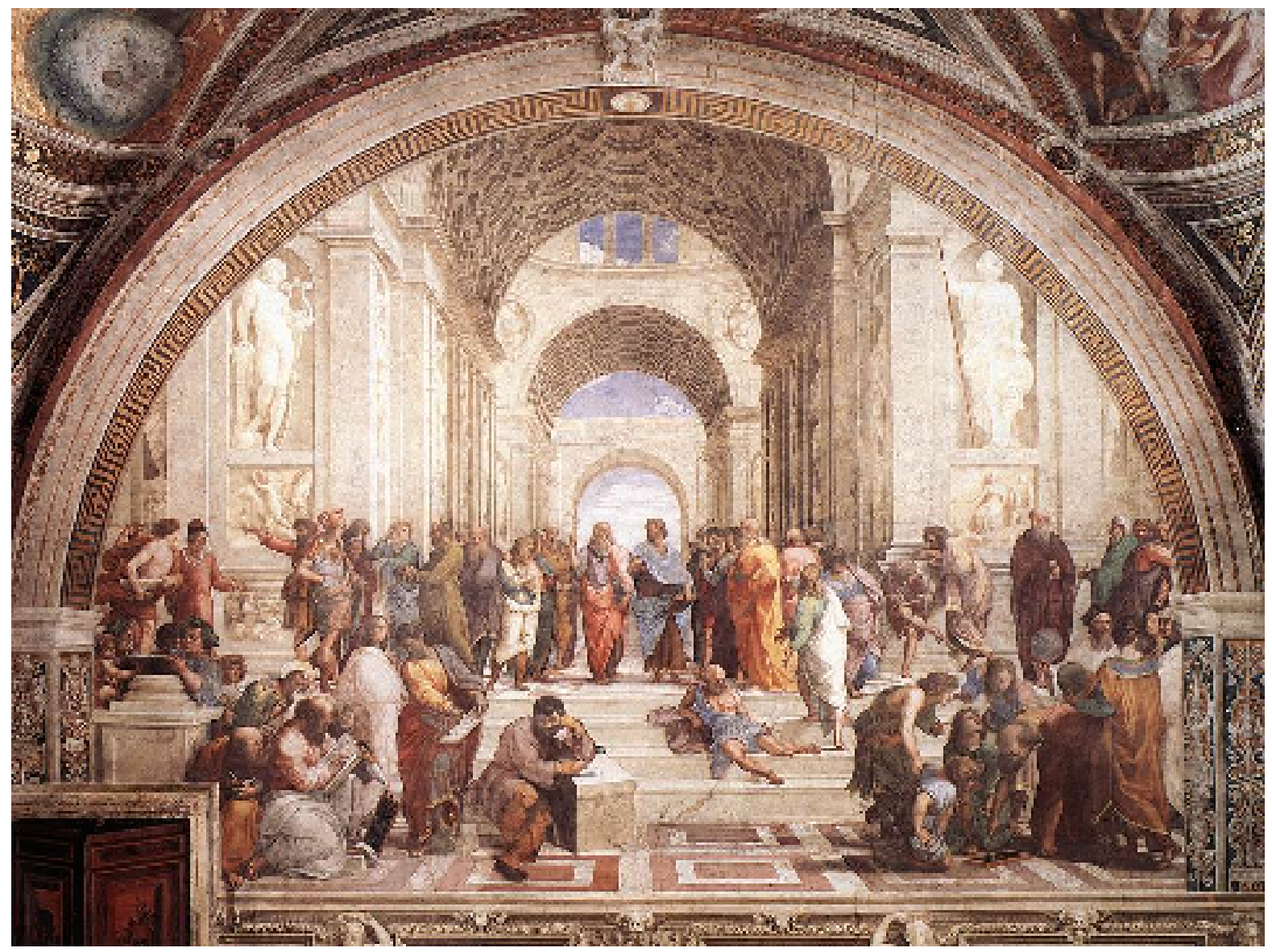

01. Rafael (1509). A Escola de Atenas - Stanza della Segnatura, Palazzi Pontifici, Vatican. http://www.wga.hu/frames-e.html?/html/r/raphael/index.html 


\subsection{Antecedentes da Geometria Euclidiana}

A palavra geometria vem do grego geometrein (geo-, "terra" e metrein, "medir") (Greenberg: 1994, p. 7). Tratava-se, pois, da ciência de medir a terra. Segundo destaca Greenberg, Heródoto ( $5^{\circ}$ século a.C.) acreditava que os egípcios já dominavam a arte da geometria, mas outras civilizações antigas também processavam informações geométricas. Na verdade, a geometria surgiu de uma série de experimentações, observações e analogias. Eram, enfim, descobertas exclusivamente empíricas, cujas respostas aproximadas eram suficientes para propósitos práticos.

Os gregos, não obstante, inicialmente com Tales de Mileto, deixaram de lado as realizações empíricas para se dedicarem a descobertas dedutivas. A sistematização, iniciada por Tales, foi continuada por Pitágoras e seus seguidores, mas foi Euclides, discípulo da escola platônica, que, por volta de 300 a.C., sistematizou definitivamente os elementos da geometria.

A geometria é uma ciência que lida com figuras que não existem no mundo visível. Euclides, e os geômetras que o precederam, obteve as idealizações necessárias à geometria de idéias inatas, ou seja, "as idealizações geométricas são idéias inatas da mente humana, presentes antes de toda ou qualquer experiência, e disponível quando “despertamos'” (Heilbron: 2003, p. 6).

\subsubsection{Sobre A Escola de Atenas}

A Escola de Atenas é uma pintura dedicada à Filosofia, ou, melhor dizendo, a um verdadeiro debate filosófico; à Verdade atingida exclusivamente por meio da razão. As duas figuras centrais são Platão e Aristóteles, os árbitros dos debates. É uma pintura que celebra o pensamento clássico, mas também é dedicada às Artes Liberais, simbolizadas pelas estátuas de Apolo e Minerva. Embora se trate de uma pintura dedicada ao pensamento clássico - os renascentistas acreditavam que o período medieval fora um período de trevas - , há referências ao ensino liberal da Idade Média1: o Trívio (Gramática, Retórica e Dialética) e o Quadrívio (Geometria, Aritmética, Astronomia e Música). A Gramática, a Aritmética e a Música estão personificadas por figuras localizadas no primeiro plano, à esquerda; A Geometria e 
a Astronomia estão personificadas por figuras em primeiro plano, à direita. Atrás deles, em pé, estão representadas a Retórica e a Dialética. Interessante notarmos que as sete disciplinas estão todas misturadas: há disciplinas que pertencem ao Quadrívio que estão no Trívio e vice-versa. Ora, mas por que falarmos, logo de início, sobre A Escola de Atenas, de Rafael? Entre muitos pensadores, Rafael pinta Pitágoras de Samos e Euclides de Alexandria, personagens de que trataremos.

O primeiro período do pensamento grego recebe o nome de pré-socrático ou naturalista -, cujo interesse filosófico estava centrado no mundo exterior, material. Iniciou-se no VI século a.C. e terminou dois séculos depois, mais ou menos nos fins do século V. Foi um período que surgiu e floresceu fora da Grécia, nas prósperas colônias gregas da Ásia Menor, Egeu (Jônia), e da Itália meridional, Sicília, favorecidas, sem dúvida, na sua obra crítica e especulativa pelas liberdades democráticas e pelo bem-estar econômico (Padovani 1954, p. 47). É do período naturalista , entre outros, Tales de Mileto, que acreditava ser a água a substância de todas as coisas; é do período naturalista, também, Anaxímenes de Mileto, que pensava ser $\mathrm{o}$ ar (ilimitado e em movimento constante) o princípio de todas as coisas; Heráclito de Éfeso, que sustentava que todas as coisas estão em movimento; e Pitágoras de Samos, que defendia a idéia segundo a qual o número é o primeiro princípio, ou seja, tudo é número. Mas iniciaremos com uma personagem que não faz parte da "Escola de Atenas"!

\subsubsection{Tales de Mileto}

Como muitos outros filósofos pré-socráticos, a vida de Tales está envolta em incertezas; mas, como o próprio nome indica, Tales, de ascendência fenícia, nasceu em Mileto, a mais importante cidade da Jônia, por volta de 625/4 - 558/6 a.C. Dela surgiram os mais antigos filósofos pré-socráticos, como Anaximandro, Anaxímenes e o próprio Tales.

Segundo o relato de Faber, Tales foi o primeiro a ver a necessidade de demonstrações lógicas em vez de experimentações a partir de ensaios e erros. "Embora suas proposições não fossem organizadas em uma seqüência lógica, nem muito profundas, as provas eram, não obstante, dedutivas, resultado de poucas suposições 'auto-evidentes até conclusões necessárias” (Faber: 1983, p. 46). Entre as descobertas de Tales está a de ter ensinado que um ano contém 365 dias; foi ele 
também que previu um eclipse solar em 585 a.C. O feito mais notável, no entanto, foi ter descoberto a altura da Grande Pirâmide comparando sua sombra com a sombra de um graveto, na vertical. "Por tal feito ele ficou conhecido pelas gerações sucessivas como um dos Sete Sábios da Grécia" (Faber: 1983, p. 47).

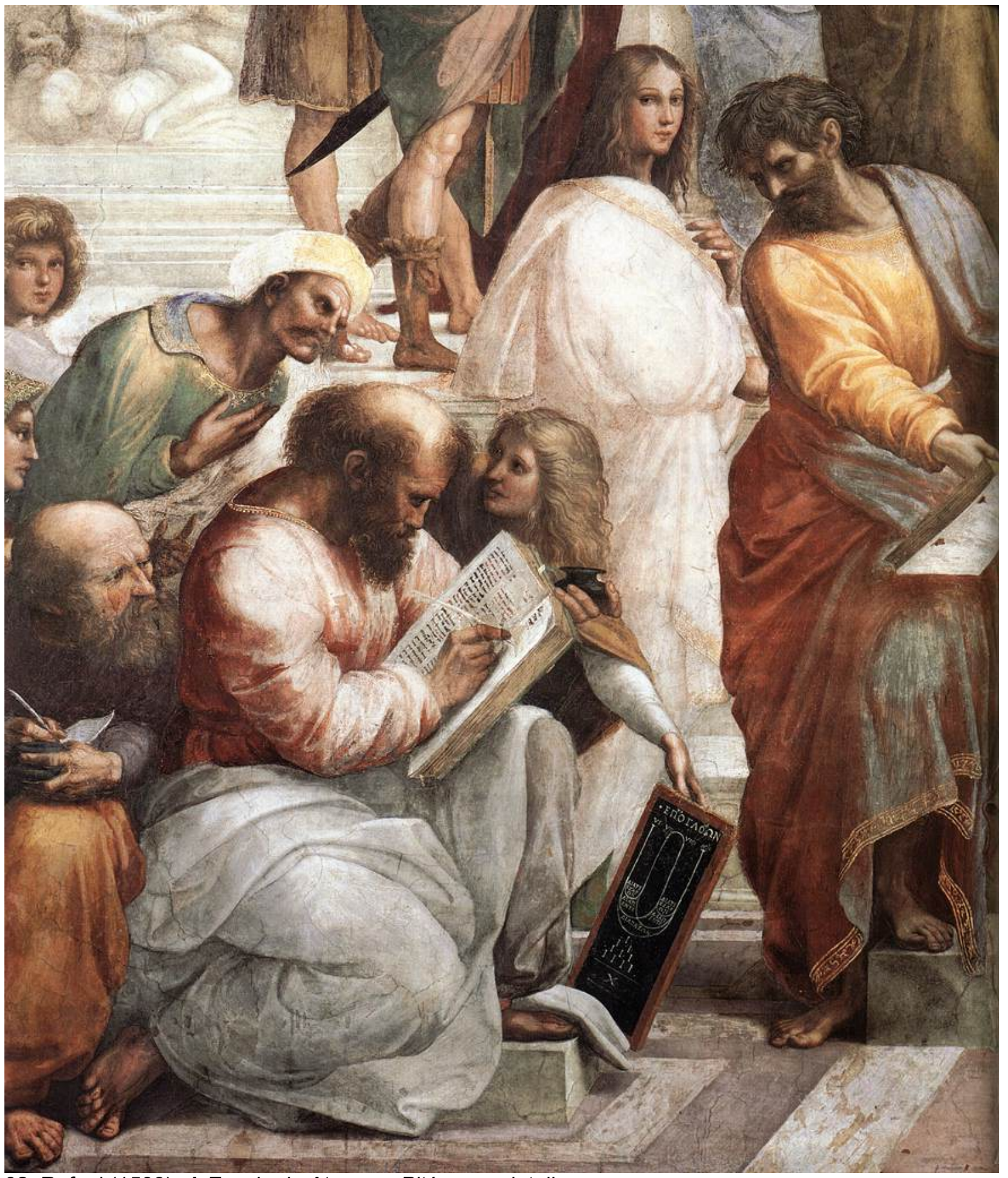

02. Rafael (1509). A Escola de Atenas - Pitágoras, detalhe.

Fonte: http://www.wga.hu/frames-e.html?/html/r/raphael/index.html. 


\subsubsection{Pitágoras de Samos}

Os autores que discorrem sobre Pitágoras são unânimes em afirmar que sua vida está envolta em mito e lenda, pois é muito difícil separar o fato da ficção. Pitágoras nasceu aproximadamente em 570 a.C., na ilha grega de Samos, numa família modesta. Seu pai, Mnesarchus, era de Tyre e sua mãe, Pythais, era de Samos. Segundo conta a lenda, a pitonisa do oráculo de Delfos avisou os pais de Pitágoras que o filho esperado seria um homem de extrema beleza, inteligência e bondade, e contribuiria de forma única para o benefício de todos os homens. Quando a criança nasceu, os seus progenitores chamaram-na Pitágoras em homenagem à pitonisa, que havia previsto para ele uma vida incomum. Dentre as lendas que cercam a vida de Pitágoras, algumas sugerem que ele não era um homem comum, mas sim um deus que tomara a forma de ser humano para melhor guiar a humanidade e ensinar a filosofia, a ciência e a arte.

Pitágoras revelou-se desde cedo uma criança prodígio. Até os 18 anos teve como mestre Hermodamas de Samos e mais tarde sofreu a influência de mestres como Ferécides de Siros, Pherekydes, Tales de Mileto e seu pupilo Anaximandro. Estes dois últimos teriam introduzido em Pitágoras idéias de matemática e de astronomia; e Thales, em particular, tê-lo-ia aconselhado a viajar para o Egito para aprender mais sobre esses temas. Foi, pois, para o Egito, onde permaneceu cerca de 25 anos. Lá teria tomado parte de muitas conversas com sacerdotes, nos templos, de onde extraiu conhecimentos que fundamentariam o seu ensinamento futuro. Aos 56 anos, aproximadamente, regressou à sua terra natal, Samos, acreditando que suas lições atrairiam muitos discípulos, o que o estimulou a fundar uma escola. Mas essa idéia fracassou em virtude da inimizade que criou com um tirano de Samos, Policrates. Este chegou a convidar Pitágoras para fazer parte de sua corte, mas o filósofo, percebendo que o objetivo da oferta era meramente silenciá-lo, recusou a "honra". Depois disso, deixou a cidade e foi morar em uma caverna, numa parte remota da ilha, onde poderia continuar seus estudos sem medo de ser perseguido ${ }^{2}$.

Para Pitágoras e os pitagóricos, a Terra era esférica, sendo uma estrela entre outras estrelas, as quais se moviam em torno de um fogo central. As distâncias das estrelas ao fogo central coincidiam com intervalos musicais. Desta forma, do universo proviria uma harmonia estelar. A observação dos astros sugeriu-lhes a 
idéia de que uma ordem domina o universo. Tal ordem se verificaria na sucessão de dias e noites, no alternar das estações e no movimento circular e perfeito das estrelas. Acredita-se que, por isso, no detalhe da figura anterior, vemos Pitágoras fazendo anotações, enquanto um rapaz segura-lhe uma tabuleta.

O rapaz, na realidade, apresenta-Ihe o esquema de uma lira harmônica com quatro cordas separadas por intervalos musicais, um tipo de resumo das principais relações musicais universais. Abaixo está o tetractus: soma dos quatro primeiros números, números por excelência, números perfeitos, base de harmonia musical como de harmonia cósmica, que ordenaria todas as coisas. Como destaca Pietra, sob a autoridade de Pitágoras foram destacadas as afinidades entre números, sons, geometria, enfim, a distribuição espacial. "Assim, temos uma das imagens emblemáticas de toda a composição. É sob o signo da ordem numérica que se organiza todo o afresco" (Pietra: 1992, p. 69).

Segundo Charles Bouleau, "no alto da tabuleta está escrito a palavra Eпог $\Delta \mathbf{O} \Omega \mathbf{N}$, que designa no Timeu um aumento inteiro da oitava parte $(1+1 / 8)$, quer dizer, o intervalo de um tom medido sobre a corda. Abaixo as palavras diatessaron, diapente, diapason estão dispostas (...)" (Bouleau apud Pietra: 1992, p. 79).

Ilustração 1: A Escola de Atenas.
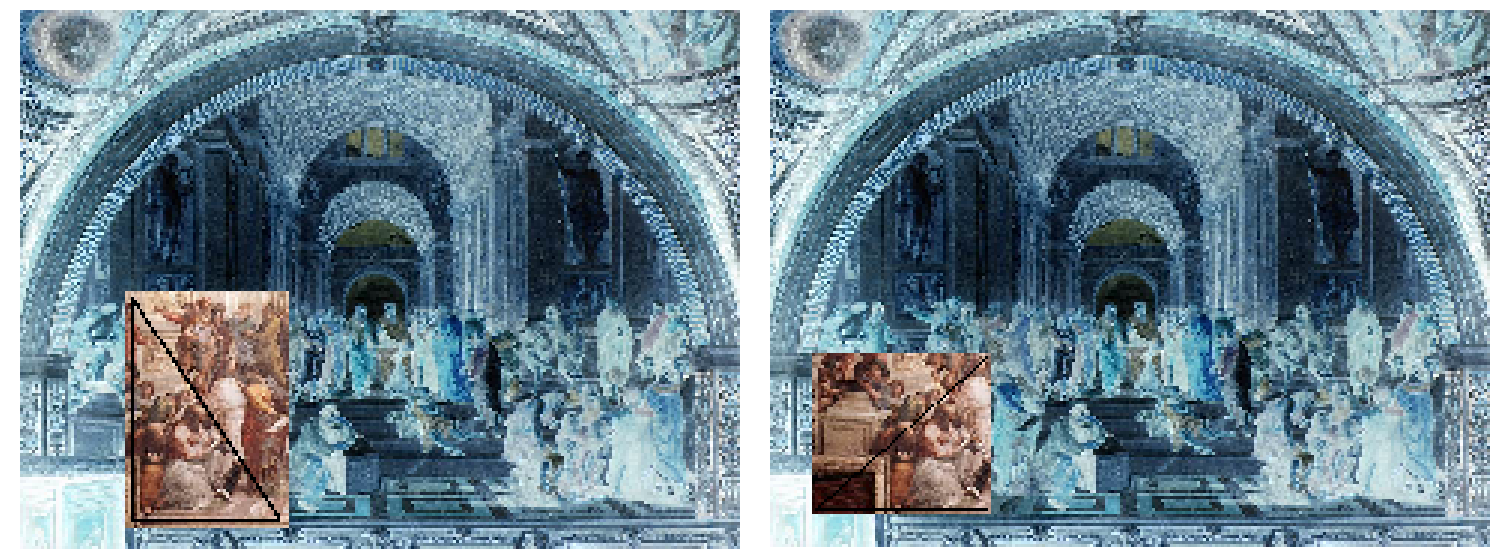

03. Rafael (1509). A Escola de Atenas

http://www.wga.hu/frames-e.html?/html/r/raphael/index.html.

Tanto em um destaque como no outro, a disposição das personagens que acompanham Pitágoras nos leva a crer que foram organizadas de modo a sugerir que Pitágoras está inscrito em um triângulo retângulo. Sendo assim, estaria fazendo referência direta ao teorema que leva seu nome: Teorema de Pitágoras. De todas as 
relações entre os números e a natureza, a mais famosa, a mais importante, é a relação que leva o nome de Pitágoras ${ }^{3}$. Trata-se de um teorema que nos fornece uma equação que é verdadeira para todos os triângulos retângulos, além de definir o ângulo reto. Por sua vez, o ângulo reto define a perpendicular e a perpendicular define as dimensões - comprimento, largura e altura do espaço onde vivemos. Em última análise, a matemática através do triângulo retângulo define a própria estrutura do nosso mundo tridimensional (Singh, 1998, p. 39).

A matemática que explica a relação existente em um triângulo retângulo é, como postula Singh, relativamente simples, ou seja, o quadrado da hipotenusa é igual à soma dos quadrados dos catetos. Ora, todo triângulo retângulo obedece a este teorema, logo, trata-se de uma verdade universal ${ }^{4}$; no entanto, achar números inteiros - os chamados trios pitagóricos - que solucionem a equação de Pitágoras torna-se cada vez mais raro à medida que os números aumentam. Os seguintes números, por exemplo, são trios pitagóricos: $3^{2}+4^{2}=5^{2}(9+16=25) ; 5^{2}+12^{2}=13^{2}$ $(25+144=169) ; 99^{2}+4.900^{2}=4.901^{2}(9.801+24.010 .000=24.019 .801)$. Mas, segundo Livio, antes mesmo do Teorema de Pitágoras ser reconhecido como uma verdade universal - que, portanto, caracterizaria todos os triângulos retângulos -, uma tabuleta de argila do período babilônico antigo (cerca de 1.600 a. C.) já continha 15 trios pitagóricos! Os babilônios descobriram que os trios pitagóricos poderiam ser encontrados a partir de um simples algoritmo. Basta escolhermos dois números inteiros $p$ e $q$, de modo que $p$ seja maior do que $q$ e procedermos da seguinte maneira: $p^{2}-q^{2} ; 2 p q ; p^{2}+q^{2}$. Por exemplo, suponhamos que $q$ seja igual a 1 e $p$ igual a 4. Então $p^{2}-q^{2}=4^{2}-1^{2}=16-1=15 ; 2 p q=2 \times 4 \times 1=8 ; p^{2}+q^{2}=4^{2}$ $+1^{2}=16+1=17$. O conjunto dos números $15,8,17$ é, pois, um trio pitagórico, porque $15^{2}+8^{2}=17^{2}(225+64=289)($ Livio: 2006, p. 41$)$.

\subsubsection{Tudo É Número}

Segundo Bornheim, Nietzsche resumiu a contribuição dos gregos para o desenvolvimento da cultura ocidental com as seguintes palavras: "Outros povos nos deram santos, os gregos nos deram sábios" (Bornheim: 1993, p. 9). A característica principal do gênio grego é, antes de tudo, o racionalismo, o intelectualismo, ou seja, 
trata-se de uma consciência elevada ao valor supremo do conhecimento racional para dominar a realidade, construir a filosofia e orientar a vida.

Foi graças a Pitágoras que os números deixaram de ser vistos como coisas que serviriam apenas para contar e calcular e passaram a ser apreciados exclusivamente por suas próprias características. "Ele percebeu que os números existem independentemente do mundo palpável e, portanto, seu estudo não é prejudicado pelas incertezas da percepção" (Singh: 1998, p. 28). Como já foi dito, Pitágoras adquiriu seus conhecimentos matemáticos em suas viagens pelo mundo antigo, sendo que muitas técnicas aprendera com os egípcios e babilônios, uma vez que estes povos haviam ultrapassado a mera contagem - foram capazes de cálculos complexos que permitiram a criação de sistemas de contabilidade sofisticados, além de elaboradas construções. Não obstante, aquilo que motivou tais descobertas foi a necessidade prática de refazer a demarcação dos campos, que se perdiam durante as cheias do Nilo.

\subsubsection{A Irmandade Pitagórica}

A famosa Irmandade Pitagórica - um grupo formado por 600 seguidores capazes de, entre outras coisas, entender os ensinamentos do mestre, além de contribuir com a criação de novas idéias e demonstrações - foi fundada numa parte da casa de Milo. Ao entrar para a Irmandade, o novo membro deveria doar tudo o que tinha para um fundo comum. Se alguém quisesse partir, receberia em dobro o que havia doado, além de ter uma lápide erguida em sua memória.

Foi Pitágoras quem criou a palavra filósofo:

$\mathrm{Na}$ imensa multidão aqui reunida alguns vieram à procura de lucros, outros foram trazidos pelas esperanças e ambições da fama e da glória. Mas entre eles existem uns poucos que vieram para observar e entender tudo o que se passa aqui. Com a vida acontece a mesma coisa. Alguns são influenciados pela busca de riqueza, enquanto outros são dominados pela febre de poder e da dominação. Mas os melhores entre os homens se dedicam à descoberta do significado e do propósito da vida. Eles tentam descobrir os segredos da natureza. Este tipo de homem eu chamo de filósofo, pois embora nenhum homem seja completamente sábio em todos os assuntos, ele pode amar a sabedoria como a chave para os segredos da natureza (Singh: 1998, p. 31). 
Os historiadores da filosofia afirmam que é muito difícil distinguir os aspectos originais da doutrina atribuída ao próprio Pitágoras dos caracteres que foram somados por seus discípulos; mas há três pontos que são comuns: 1) o número é o primeiro princípio; o número e suas relações são os elementos de todas as coisas; o estudo do número reflete-se também no comportamento humano; 2) a forma dualista da teoria dos opostos, de tão largas conseqüências para todo o pensamento présocrático, também pode ser atribuída a Pitágoras; 3) a descoberta de verdades de ordem matemática, sobretudo o famoso teorema que lhe é atribuído (Bornheim: 1993, p. 49). Logo, os pitagóricos acabaram chegando à conclusão de que o princípio matemático é, na verdade, o princípio de todas as coisas, por terem se dedicado profundamente às matemáticas, atingindo, pois, grandes progressos.

Pelo fato de os números serem os primeiros entre todos os princípios matemáticos, é natural que os pitagóricos tenham identificado propriedades numéricas na justiça, na alma e no espírito, assim como em harmonias musicais, por exemplo. Diante dessas relações, "supuseram que os elementos dos números são os elementos de todas as coisas e que todo o universo é harmonia e número. $\mathrm{E}$ recolheram e ordenaram todas as concordâncias que encontravam nos números e harmonias com as manifestações e partes do universo, assim como com a ordem total" (Bornheim, 1993, p. 50).

Pitágoras, portanto, além de estudar as relações entre os números, também foi fascinado pelas ligações existentes entre estes e a natureza, uma vez que os fenômenos naturais são governados por leis; e estas leis podem ser descritas por meio de equações matemáticas. Logo, é correto concluir - segundo Pitágoras - que os números estão ocultos em tudo, inclusive nas órbitas dos planetas. Desde a divulgação destas descobertas os cientistas vêm tentando identificar regras matemáticas que parecem governar cada processo físico. 


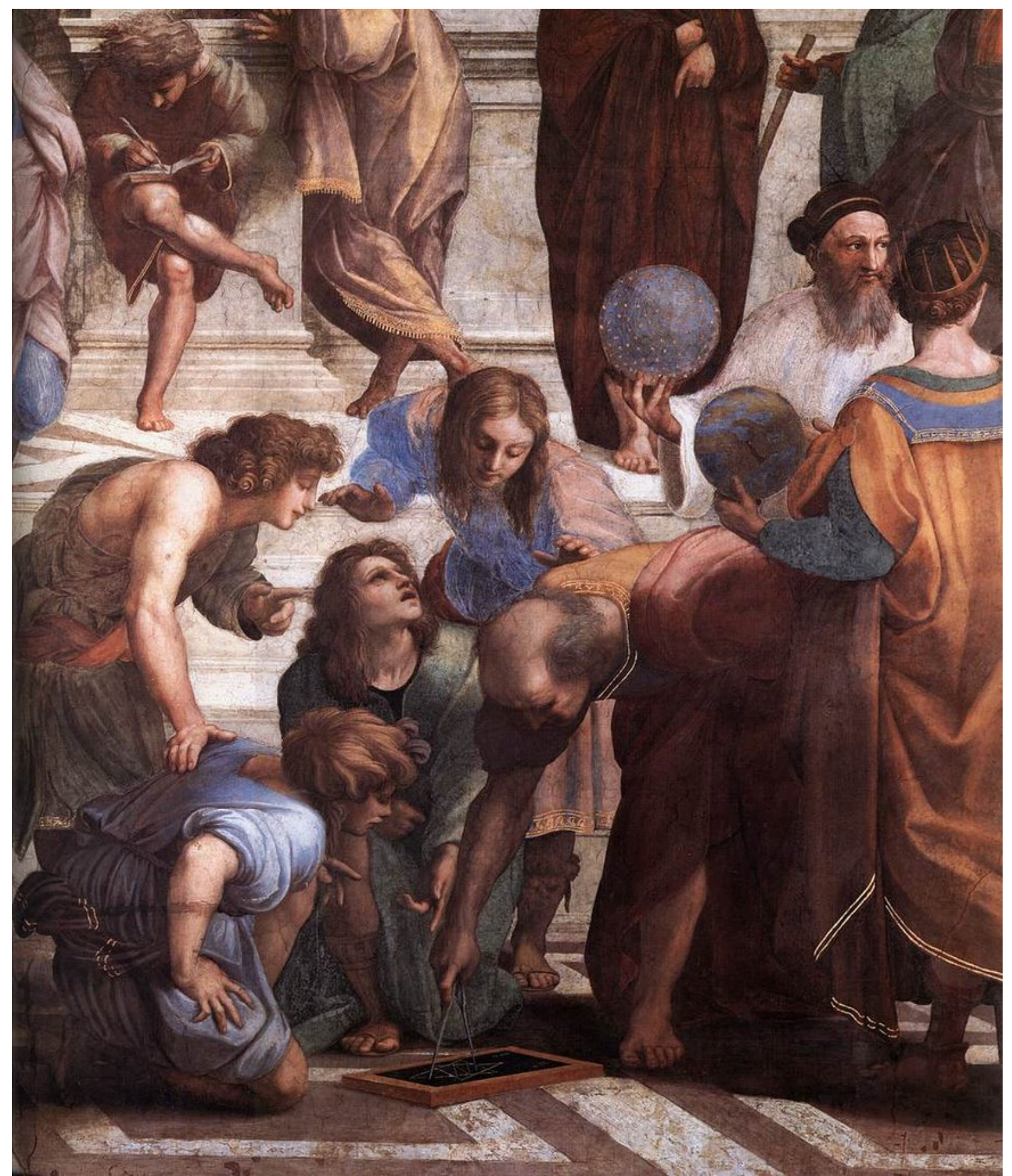

04. Rafael (1509). A Escola De Atenas - Euclides, detalhe.

Fonte: http://www.wga.hu/frames-e.html?/html/r/raphael/index.html.

\subsection{Geometria Euclidiana}

Euclides, juntamente com Arquimedes e Apolônio, faz parte da Era de Ouro dos matemáticos gregos. Mas as informações sobre a sua vida, como a de muitos outros gregos ilustres, é tão escassa e obscura que nenhum lugar de nascimento é 
associado a seu nome. No entanto, Euclides é conhecido como Euclides de Alexandria, porque foi chamado para lá para ensinar matemática. Euclides e Os elementos são freqüentemente considerados sinônimos; na realidade, ele escreveu cerca de uma dúzia de tratados, cobrindo tópicos variados, desde óptica, astronomia e mecânica até um livro sobre secções cônicas.

As cinco obras de Euclides que sobreviveram e chegaram até nós são Os elementos, Os dados, Divisão de figuras, Os fenômenos e Óptica. Segundo Boyer, Óptica tem um interesse especial por ser um dos primeiros trabalhos sobre perspectiva, ou a geometria da visão direta. Na visão de Boyer, Optica "é digna de nota por adotar uma teoria de 'emissão' para a visão, segundo a qual o olho envia raios que vão até o objeto, em contraste com uma doutrina rival de Aristóteles, na qual uma atividade num meio caminha em linha reta do objeto para o olho" (Boyer: 1999, p. 70). Um objetivo da Óptica era combater a insistência dos epicuristas de que um objeto é exatamente do tamanho que aparenta, não se devendo fazer ajustes para compensar os efeitos da perspectiva.

Rigorosamente falando, o sucesso de Euclides não se deu em função de nenhuma descoberta nova, mas por sua capacidade de expô-la. Em função disso, Os elementos é, na verdade, um livro-texto que, embora não tenha sido o único, de longe superou os de seus competidores, haja vista que foi o único que sobreviveu.

Não eram, como se pensa às vezes, um compêndio de todo o conhecimento
geométrico; ao contrário, trata-se de um texto introdutório cobrindo toda a
matemática elementar - isto é, aritmética (no sentido de "teoria dos
números"), geometria sintética (de pontos, retas, círculos e esferas) e álgebra
(não no sentido simbólico moderno, mas um equivalente em roupagem
geométrica) (Boyer: 1999, p. 72).

Enfim, como o próprio Boyer ressalta, Euclides não manifestou nenhuma pretensão de originalidade, pois utilizou grandemente obras de seus predecessores. Tudo indica que a ordenação tenha sido dele, e presumivelmente algumas provas foram fornecidas por ele; mas, afora isso, é difícil avaliar o grau de originalidade dessa obra, a mais renomada na história da matemática. Os elementos de Euclides estão divididos em 13 livros ou capítulos, sendo os seis primeiros sobre geometria plana elementar e os três seguintes sobre teoria dos números; o Livro $\mathrm{X}$, sobre incomensuráveis; e os três últimos versam principalmente sobre geometria no espaço. 
Boyer observa que, segundo a visão de Aristóteles, há uma clara divisão entre um axioma e um postulado, embora os matemáticos modernos não vejam tal separação. Para o estagirita, segundo Boyer, axiomas "devem ser convincentes por eles mesmos - verdades comuns a todos os estudos —, mas os postulados são menos óbvios e não pressupõem o assentimento do estudante, pois dizem respeito somente ao assunto em discussão" (Boyer: 1999, p. 72). Ao que tudo indica, a partir dos manuscritos de Euclides, ele não fez distinção entre axiomas e postulados.

Postulados. Seja postulado o seguinte:

1. Traçar uma reta de qualquer ponto a qualquer ponto

2. Prolongar uma reta finita continuamente em uma linha reta

3. Descrever um círculo com qualquer centro e qualquer raio

4. Que todos os ângulos retos são iguais

5. Se uma reta secante a duas outras forma ângulos, de um mesmo lado dessa secante, cuja soma é menor que dois ângulos retos, então essas retas, se prolongadas suficientemente, encontrar-se-ão em um ponto desse mesmo lado

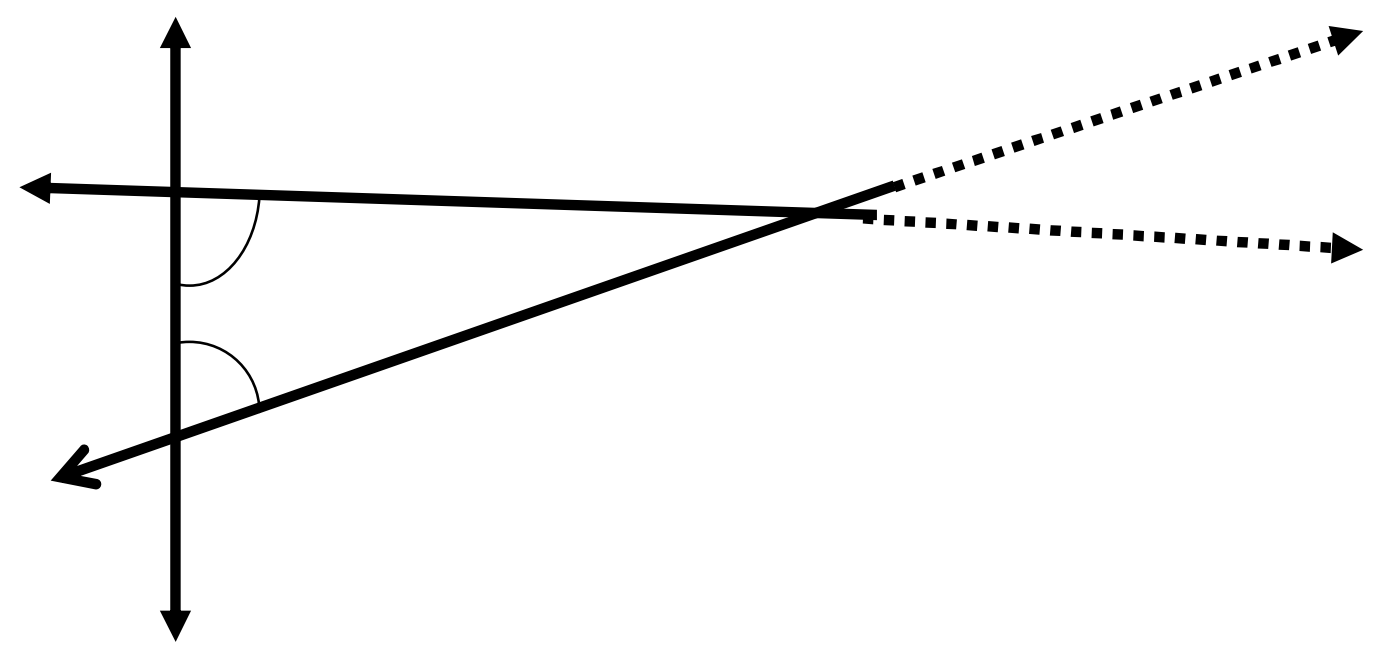

05. Convite às Geometrias não-Euclidianas, p. 05. 
Noções Comuns:

1. Coisas que são iguais a uma mesma coisa são também iguais entre si

2. Se iguais são somados a iguais, os totais são iguais

3. Se iguais são subtraídos de iguais, os restos são iguais

4. Coisas que coincidem uma com a outra são iguais uma à outra

5. O todo é maior que a parte

Aparentemente, noções como "o todo é maior que a parte" podem parecer uma obviedade; ademais, é muito mais fácil criticar a obra de alguém à luz de desenvolvimentos posteriores. Mas, não devemos nos esquecer, em seu tempo Os elementos constituíram o desenvolvimento lógico mais rigorosamente datado da matemática elementar que já fora escrito, e dois mil anos deveriam se passar antes que surgisse uma apresentação mais cuidadosa. Durante este longo intervalo a maior parte dos matemáticos considerou a exposição de Euclides logicamente satisfatória e pedagogicamente aceitável. Hoje em dia, a maior parte das proposições de Os elementos é dada em qualquer curso do ensino médio. Contém os teoremas familiares sobre congruência de triângulos, sobre construções simples com régua e compasso sobre desigualdades relativas a ângulos e lados de um triângulo, sobre propriedades de retas paralelas e sobre paralelogramos.

\subsubsection{A Influência de Os elementos}

Os elementos de Euclides não só constituem a mais antiga obra matemática grega importante que chegou até nós, mas é também um dos textos mais influentes de todos os tempos. Foi composto em 300 a.C.. aproximadamente, e foi copiado e recopiado repetidamente depois. Variações inevitavelmente se inseriram, alguns editores posteriores, notadamente Teon de Alexandria no fim do quarto século, tentaram "melhorar" o original. No entanto, só foi possível obter uma boa impressão do conteúdo da versão original comparando a mais de meia dúzia de cópias manuscritas gregas, datando principalmente dos séculos X a XII. Cópias de Os elementos também chegaram até nós em traduções árabes, mais tarde vertido para 
o latim no século XII, e, finalmente, no século $X V I$, em vernáculo. A primeira versão impressa de Os elementos apareceu em Veneza em 1482, um dos primeiros livros de matemática impressos.

\subsubsection{O Postulado das Retas Paralelas}

Retas paralelas são retas que, estando no mesmo plano e prolongadas infinitamente em ambas as direções, não se encontram em nenhum ponto. Ou seja, de acordo com a Geometria Euclidiana, a distância perpendicular entre as linhas permanece exatamente a mesma, à medida que nos movemos para a direita. $\mathrm{O}$ problema de tal postulado é o fato de que tais paralelas implicariam a existência de um ponto de encontro de retas concorrentes, mesmo que este encontro se desse fora dos limites do factível. Em outras palavras, teoricamente, seria necessário ir além do universo inteiro! Isso seria possível? Questão interessante, já que a veracidade do quinto postulado jamais havia sido questionada, pelo menos até meados do século XIX.

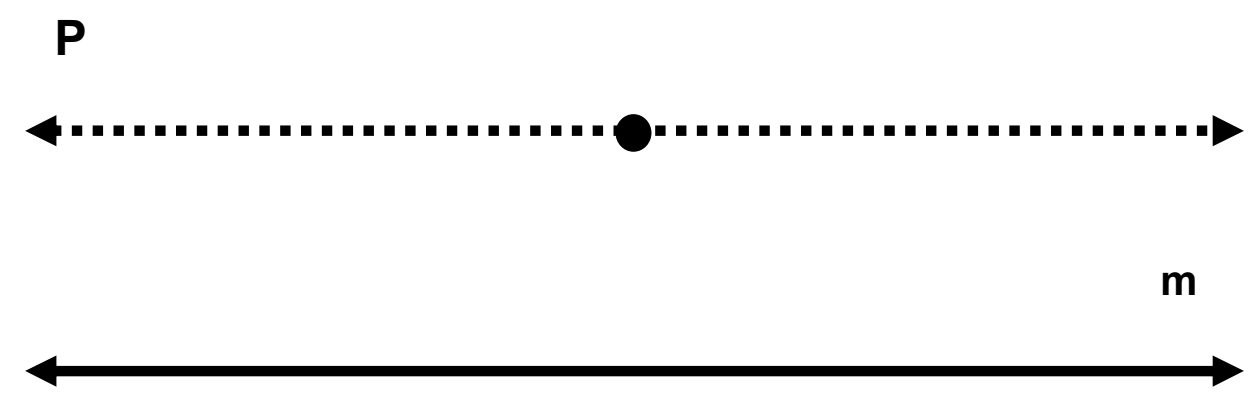

06. retas paralelas

Ora, se por um ponto $\mathrm{P}$ passa apenas uma única reta $m$, ela será paralela a outra reta nessas mesmas condições - reta I, por exemplo. Como observa Greenberg, se considerarmos os axiomas da geometria abstrações da experiência, poderemos ver diferenças entre esse postulado e os outros quatro.

Os dois primeiros postulados são abstrações de nossa experiência desenhando com uma régua; o terceiro postulado deriva de nossa experiência desenhando com um compasso. O quarto postulado é talvez 0 menos óbvio como uma abstração; no entanto ele deriva de nossa experiência medindo ângulos com um transferidor (onde a soma de dois ângulos suplementares é $180^{\circ}$, de modo que se os ângulos suplementares são congruentes, cada um deles deve medir $90^{\circ}$ ) (Greenberg: 1994, p. 20). 
O quinto postulado é diferente dos outros porque, primeiramente, não poderíamos verificar empiricamente se duas retas paralelas podem, de fato, encontrar-se ou não, uma vez que, conforme observa Greenberg (1994, p. 20), só traçamos segmentos de reta, e não linhas. Na realidade, mesmo podendo prolongar um segmento de reta cada vez mais longe, não podemos fazê-lo para sempre. Segundo Kubrusly ${ }^{5}$, no entanto, as duas retas acabariam se encontrando em um ponto que não necessariamente precisaria ser construído, pois teria sua existência garantida dentro do nosso pensamento. Trata-se, pois, de um postulado que acabou gerando questões filosóficas, diferente dos outros que são auto-evidentes, nunca remeteram nossos pensamentos para o infinito.

A geometria euclidiana é uma geometria de fácil entendimento, uma vez que não contraria nossos sentidos. Ora, em função de ser facilmente aceita por nossa intuição, conforme observa Coutinho (2002, p. 35), por cerca de dois mil anos a geometria euclidiana foi a única possível. Porém, com o passar dos anos, renomados matemáticos tomaram para si a incumbência de provar o $5^{\circ}$ Postulado de Euclides, pois consideravam tal postulado o menos intuitivo e de redação muito complicada. Vejamos o que diz Coutinho: essa pretensão não foi alcançada, porquanto o $5^{\circ}$ Postulado não é uma
conseqüência lógica dos quatro anteriores. Substituindo-o, criam-se novas
geometrias, tão boas e consistentes quanto a euclidiana. A geometria
euclidiana, transmitida de geração em geração por mais de dois mil anos,
não era a única. As mentes criativas dos matemáticos Bolyai, Lobachevsky,
Gauss e Riemann lançaram as bases de outras geometrias tão logicamente
aceitas quando a euclidiana. Uma dessas geometrias não-euclidianas
encontra aplicação na Teoria da Relatividade, o que se justifica, pois sendo
curvo o Universo einsteiniano, a geometria euclidiana não é aplicada
(Coutinho: 2002, p. 36 ).

Surgiriam outras geometrias; geometrias que causariam estranheza àqueles acostumados apenas aos postulados de Euclides. Entrariam em cena a chamada geometria não-Euclidiana.

\subsection{Geometria não-Euclidiana}

A geometria não-euclidiana resultou da busca por alternativas ao $5^{\circ}$ Postulado de Euclides: o Postulado das Paralelas. Como mencionado, o $5^{\circ}$ Postulado, como 
observa Greenberg, não pode ser verificado empiricamente, ou seja, se duas linhas, de fato, encontram-se ou não, uma vez que só podemos desenhar segmentos de retas. "Nós podemos estender segmentos de retas cada vez mais longe para ver se elas se encontram, mas não podemos fazer isso para sempre. Nosso único recurso é verificar o paralelismo indiretamente, usando outros critérios que não os da definição" (Greenberg: 1993, p. 20).

\subsubsection{A Descoberta da Geometria não-Euclidiana}

A descoberta da geometria não-euclidiana se iniciou quase simultaneamente pelas mãos de dois jovens e eminentes matemáticos: János Bolyai e Nicolai Lobachevsky. Bolyai publicou suas primeiras descobertas sobre a geometria nãoeuclidiana em um apêndice ao livro de seu pai, que procurava provar o $5^{\circ}$ Postulado. Porém, de acordo com Greenberg, há evidências de que o matemático alemão Carl Friedrich Gauss tinha antecipado algumas importantes descobertas de Bolyai, pois vinha trabalhando com a geometria não-euclidiana desde os 15 anos de idade. Com o decorrer dos anos, cada vez mais Gauss se convencia da necessidade de uma alternativa às proposições de Euclides. Ao se referir à soma dos ângulos internos de um triângulo, Gauss dizia que a mera possibilidade de que a soma dos ângulos internos de um triângulo seja menor do que $180^{\circ}$ conduziria a uma geometria curiosa, bem diferente da nossa (a euclidiana), mas completamente consistente. Com tais indagações Gauss refutava um dos alicerces da filosofia kantiana. "A descoberta da geometria não-euclidiana de Gauss refutou a posição de Kant de que o espaço euclidiano é inerente à estrutura de nossa mente. Em sua Crítica da Razão Pura (1781) Kant declarou que "o conceito [euclidiano] de espaço não é, de jeito nenhum, de origem empírica, mas uma necessidade inevitável do pensamento" (Greenberg: 1994, p. 182).

Quem, contudo, teve a iniciativa e a coragem de publicar as primeiras investigações sobre a possibilidade de outras geometrias foi o matemático russo Nicolai Ivanovich Lobachevsky. De acordo com seu postulado, por um ponto $\mathbf{P}$, fora de uma reta $\mathbf{r}$, passa mais de uma reta paralela à reta $\mathbf{r}$. Ou seja, entre as retas a e b passam infinitas retas, que não interceptam a reta $\mathbf{r}$. 


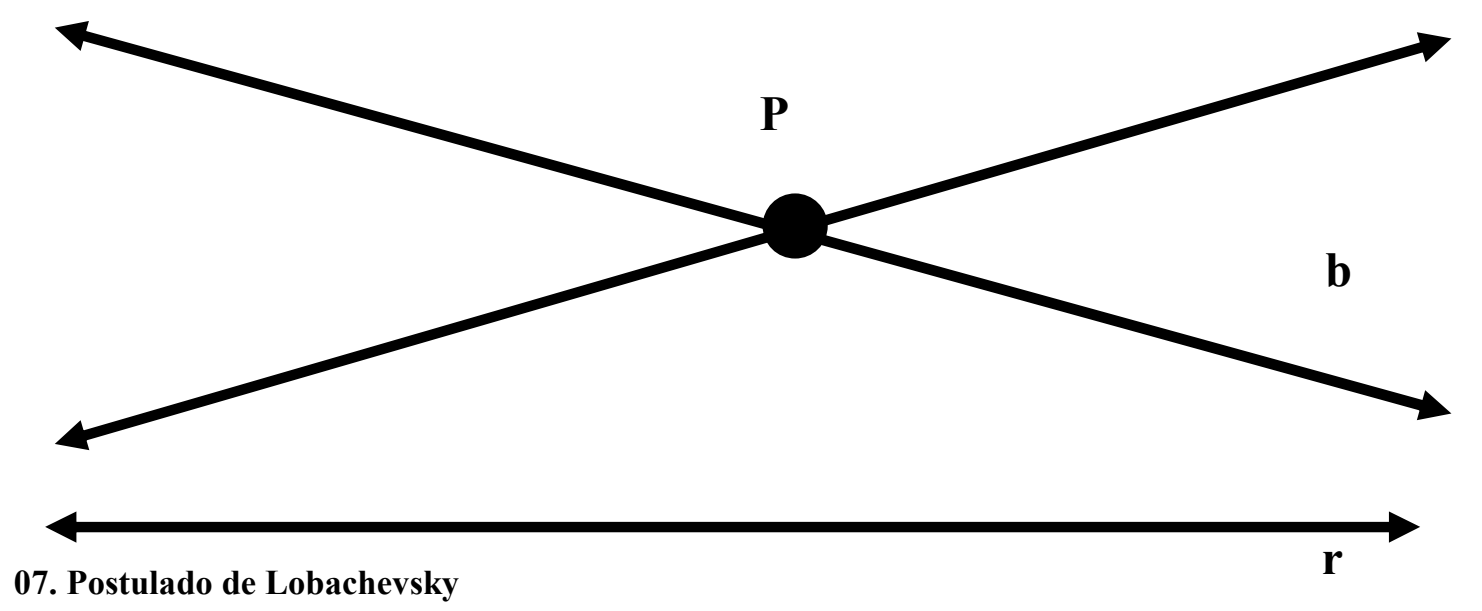

É, inicialmente, desconcertante para nós, seres tridimensionais, imaginarmos a possibilidade de por um ponto $\mathbf{P}$, fora de uma reta $\mathbf{r}$, passar mais de uma reta paralela à reta $\mathbf{r}$ !

\subsubsection{Os Espaços Curvos}

Retomando a idéia anterior, é impossível imaginarmos que por um ponto $\mathrm{P}$, fora de uma reta $r$, possam passar mais de uma reta paralela à reta se pensarmos em um espaço plano, em um espaço Euclidiano. O mundo matemático só começou a levar a sério a geometria não-euclidiana após a morte de Gauss, quando suas correspondências foram publicadas. Greenberg diz que, então, muitos ilustres matemáticos (como Beltrami, Klein, Poincaré e Riemann) revisaram, ampliaram e aplicaram as descobertas de Gauss a outros ramos da matemática. Em 1868 Beltrami finalmente confirmou que nenhuma prova era possível para o postulado das paralelas. Bernard Riemann, ex-aluno de Gauss, por sua vez, "inventou o conceito de uma superfície abstrata que não precisa estar atrelada a nenhum espaço tridimensional euclidiano, sobre o qual as 'linhas' podem ser interpretadas como geodésicas e a curvatura intrínseca da superfície pode ser definida de modo preciso" (Greenberg: 1994, p. 185). Notemos que Greenberg põe aspas na palavra linhas. Isso porque, com essa nova realidade, teremos superfícies que terão curvatura constante positiva e superfície que terão curvatura constante negativa. Este, 
segundo Greenberg, é o ponto de vista dos geômetras hoje em dia sobre a realidade dos planos não-euclidianos.

Do mesmo modo que as linhas retas são as trajetórias mais curtas conectando dois pontos de um espaço plano, os movimentos nos espaços curvos percorrem as linhas curvas mais curtas entre dois pontos. Tais curvas são chamadas geodésicas. Ou seja, sobre a superfície de uma esfera podemos traçar somente curvas, e não linhas retas. De todas as curvas que conectam dois pontos, a mais curta é o arco de um grande círculo. Por conseguinte, as geodésicas sobre a superfície de uma esfera são os arcos de grandes círculos.

Ao fazermos referência ao postulado de Lobachevsky, portanto, devemos ter em mente o que é reta geodésica de um espaço modelo, ou seja, em um espaço onde seria possível outra geometria, a geometria não-Euclidiana. Nos exemplos abaixo podemos perceber perfeitamente o que são linhas geodésicas. Entendendo o que são retas geodésicas torna-se mais fácil entendermos que a soma dos ângulos internos de um triângulo será sempre $180^{\circ}$ desde que esse triângulo esteja em um plano cuja curvatura seja zero. Portanto, afirmações desse tipo só passam a ser verdadeiras dependendo da geometria que foi utilizada. Por exemplo, seres 2D caminhando ao longo das geodésicas pensariam estar percorrendo linhas retas. Por isso fica tão difícil entenderem como podem voltar ao ponto de partida. Além disso, como aqueles seres acham que seu universo ocupa todos os lugares possíveis, ficam confusos quando tentam imaginá-lo torcido. Se o Universo tivesse essa forma, voltaríamos ao ponto de partida após uma longa viagem em linha "reta" e também não entenderíamos a sua curvatura.

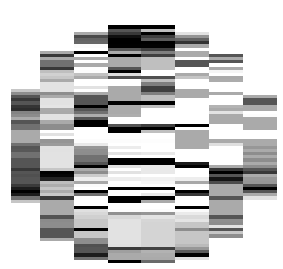

Curvatura positiva:

Soma dos ângulos do triângulo $>180^{\circ}$

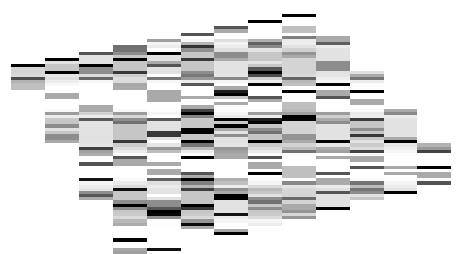

Curvatura zero:

Soma dos ângulos do triângulo $=180^{\circ}$

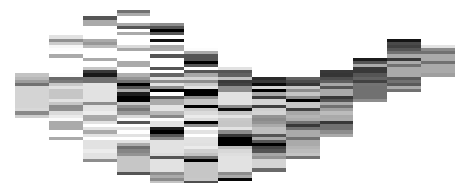

Curvatura negativa:

Soma dos ângulos do triângulo $<180^{\circ}$.

08. Curvaturas

Sigamos a tabela abaixo e comparemos, pois, as características dos três espaços que temos - o espaço euclidiano; o espaço esférico e o espaço hiperbólico 
— para tentarmos entender melhor os desdobramentos relacionados à geometria não-euclidiana.

\begin{tabular}{|c|c|}
\hline \multicolumn{2}{|c|}{ Comparando os três espaços uniformes } \\
\hline \multirow{3}{*}{ Espaço euclidiano } & $\begin{array}{l}\text { Por meio de um ponto dado podemos traçar somente uma reta } \\
\text { paralela }\end{array}$ \\
\hline & $\begin{array}{c}\text { A soma dos ângulos internos de um triângulo é igual a } 180^{\circ} \\
\text { graus }\end{array}$ \\
\hline & A circunferência de um círculo é igual a $\pi$ vezes o seu diâmetro \\
\hline \multirow{3}{*}{ Espaço esférico } & $\begin{array}{c}\text { Por meio de um ponto dado não podemos traçar nenhuma } \\
\text { paralela a um ponto dado }\end{array}$ \\
\hline & $\begin{array}{l}\text { A soma dos ângulos internos de um triângulo é maior do que } \\
180^{\circ} \text { graus }\end{array}$ \\
\hline & $\begin{array}{l}\begin{array}{l}\text { A circunferência de um círculo é menor do que } \pi \text { vezes o seu } \\
\text { diâmetro }\end{array} \\
\end{array}$ \\
\hline \multirow{3}{*}{$\begin{array}{l}\text { Espaço } \\
\text { hiperbólico }\end{array}$} & $\begin{array}{c}\text { Por meio de um ponto dado podemos traçar mais de uma linha } \\
\text { reta }\end{array}$ \\
\hline & $\begin{array}{l}\text { A soma dos ângulos internos de um triângulo é menor do que } \\
180^{\circ} \text { graus }\end{array}$ \\
\hline & $\begin{array}{l}\text { A circunferência de um círculo é maior do que m vezes o seu } \\
\text { diâmetro }\end{array}$ \\
\hline
\end{tabular}

09. Tabela comparativa

\subsubsection{Desdobramentos da Geometria não-Euclidiana}

Ora, como vimos, a geometria não-euclidiana surgiu de esforços para provar, basicamente, o $5^{\circ}$ Postulado de Euclides: o postulado das retas paralelas. Pelo que pudemos perceber, a geometria não-euclidiana não invalida a geometria euclidiana; pelo contrário, elas se mostram extremamente necessárias e complementares, uma para ser usada em espaços cuja curvatura é zero, e a outra em espaços com curvatura positiva ou negativa. Não existe uma geometria que dê conta tanto dos espaços euclidianos como de espaços não-euclidianos. Isso, semelhantemente, aconteceu com as duas grandes realizações intelectuais da primeira metade do 
século XX: a teoria da relatividade geral e a mecânica quântica. Segundo as palavras de Hawking, a teoria da relatividade geral

descreve a força da gravidade e a estrutura em grande escala do universo, isto é, a estrutura das escalas de alguns poucos quilômetros até escalas tão grandes quanto um milhão de milhão de milhão de milhão de quilômetros (1 seguido de 24 zeros), o tamanho do espaço observável. A mecânica quântica, por outro lado, trata de fenômenos em escalas muito pequenas, tais como um milionésimo de milionésimo de centímetro (Hawking: 1997, p. 18).

Como observa Greenberg, a maioria das pessoas não se dá conta da revolução e do impacto que foi, em termos de geometria, a descoberta da geometria não-euclidiana. Para termos uma idéia da sua importância e impacto, a grande revolução na física só ocorreu quando alguns matemáticos se puseram a estudar a geometria de espaços curvos em detalhes. Segundo Gleiser (1997, p. 332), sem entender a geometria de espaços curvos, o genial Einstein não teria formulado matematicamente sua famosa teoria da relatividade geral. Ora, ainda conforme Gleiser (1997, p. 334), foi só após Einstein dominar as sutilezas da geometria nãoeuclidiana que ele obteve as equações da relatividade geral em sua forma definitiva. "Basicamente, a teoria se reduz a duas equações, uma relacionando a geometria do espaço-tempo e distribuição de massa-energia ('Equação de Einstein') e a outra descrevendo movimentos numa geometria curva ('Equação da Geodésica')" (Gleiser: 1997, p. 334).

David Bodanis, em seu livro $E=m c^{2}$ Uma biografia da equação que mudou o mundo e o que ela significa, conta-nos porque resolveu escrever o livro. Segundo ele, no final de uma entrevista com a atriz Cameron Diaz a uma revista de cinema, o entrevistador perguntou se havia alguma coisa que ela gostaria de saber. Ela, então, respondeu que gostaria de saber o que $E=m c^{2}$ significa realmente. "Todo mundo sabe que $E=m c^{2}$ é realmente importante, mas geralmente não sabe o que significa; isso é frustrante, porque a equação é tão curtinha que seria de imaginar que fosse algo compreensível" (apud Bodanis: 2001, p. 7). As pessoas que, de fato, queiram entender o significado da equação que mudou o mundo devem estudar a geometria não-euclidiana, pois do contrário não conseguirão entender a geometria do espaçotempo.

Enfim, o estudo das geometrias não-euclidianas acaba nos conduzindo, forçosamente, a um campo específico do saber: a física. Na verdade, não se trata de abordagens especializadas, no mesmo nível de aprofundamento dos teóricos 
expertos no assunto; seria muito mais uma aproximação para verificar o poder de alcance de uma geometria que se iniciou, digamos, estudando o espaço na Terra e estendeu-se ao espaço no universo.

\subsubsection{Geometria do Espaço-Tempo}

Para nós, simples mortais, alheios às complexidades da astronomia e da física, não há uma razão aparentemente clara que nos faça perder noites de sono pensando na relação entre as geometrias não-euclidianas e os espaços curvos da geometria do espaço-tempo! Carl Sagan conta que há uma antiga piada sobre um expositor que relatara que o Sol, em cinco bilhões de anos, aumentará de tamanho, engolindo os planetas Mercúrio, Vênus e, finalmente, a Terra. Na saída do auditório, um ansioso membro da platéia faz a seguinte pergunta:

_Desculpe-me, doutor, o senhor disse que o Sol vai arrebentar

a Terra em cinco bilhões de anos?

_Sim, mais ou menos.

_Graças a Deus. Por um momento pensei que tivesse dito cinco milhões (Sagan: 1998, p. 13).

Quando isso acontecer o Sol brilhará mais do que todas as estrelas reunidas em nossa galáxia (cerca de 100 bilhões). A explosão seria de uma intensidade tal que as camadas exteriores do Sol seriam impulsionadas com tamanha velocidade que escapariam completamente do seu campo gravitacional; no centro da estrela ficaria apenas um objeto pequeno e fantástico, muito menor do que a Terra, pesando, no entanto, uma ou mais toneladas por $\mathrm{cm}^{3}$ (Coutinho: 2001, p. 1).

Há muito tempo os cientistas vêm estudando possibilidades de enfrentamento da ameaça dessa catástrofe natural e aparentemente inevitável. Segundo relata Coutinho, o Dr. Malcolm Igor Ariamatar foi indicado para supervisionar a construção de uma espaçonave, cosmos I, que faria parte do Projeto Euclides, cuja missão seria deixar a Terra rumo a um planeta desconhecido que oferecesse condições de sobrevivência semelhantes às que temos, a fim de preservar a espécie humana, que estava condenada à extinção.

Um dos fatores indispensáveis para o êxito da missão seria precisar os cálculos da rota da nave, o que implicaria, como observa Coutinho, saber a natureza euclidiana ou não-euclidiana do espaço cósmico; logo, saber se o Universo é curvo ou não. Em outras palavras, qual a geometria deveria seria utilizada: uma "torta", já 
que a "retidão" da geometria euclidiana provocaria distorções na rota da nave, comprometendo, assim, o sucesso da missão? Caso optassem pela utilização da geometria euclidiana, o perigo de conduzir a nave rumo a uma singularidade do espaço, já que a viagem ocorreria sem escalas, deveria ser levado em consideração.

Uma singularidade acontece quando a superfície de uma região atinge o tamanho zero:

E a partir do momento em que a superfície da região encolhe a zero, o mesmo deve acontecer com seu volume. Toda a matéria dentro da estrela será comprimida em uma região de volume zero, assim a densidade da matéria e a curvatura do espaço-tempo se tornarão infinitas. Em outras palavras, teremos uma singularidade contida em uma região do espaçotempo conhecida como buraco negro (Hawking: 1988, p. 53) ${ }^{6}$.

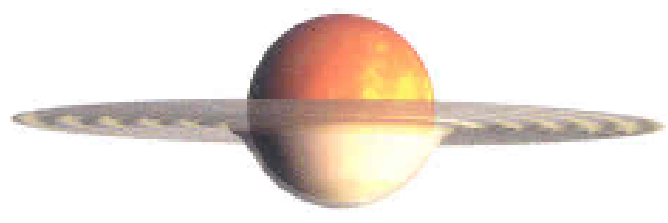

Uma estrela maciça começa a colapsar sob sua sua própria pressio gravíacional

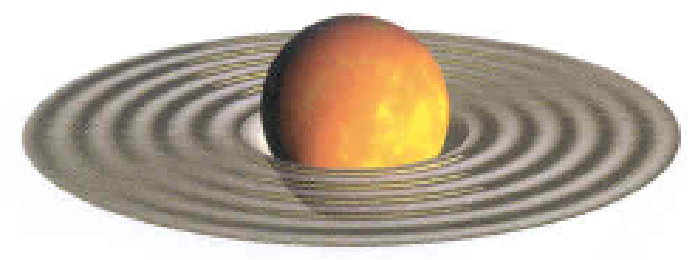

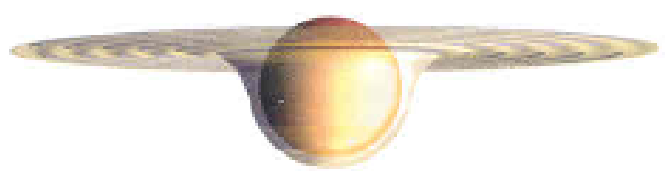

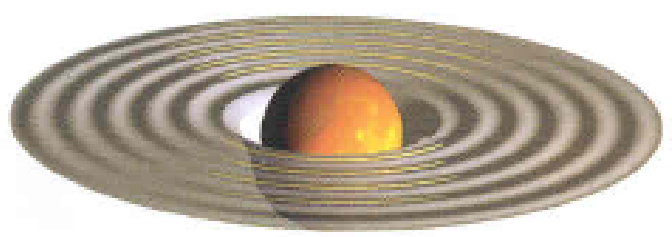

10. Breve História do Tempo llustrada, p. 114/5. 


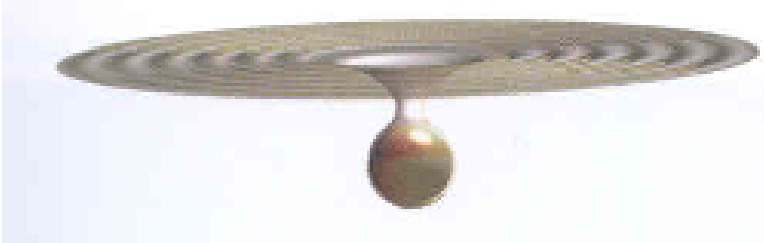

A estrela ainda pode ser vista, mas está próxima de formar um horizonte de eventos

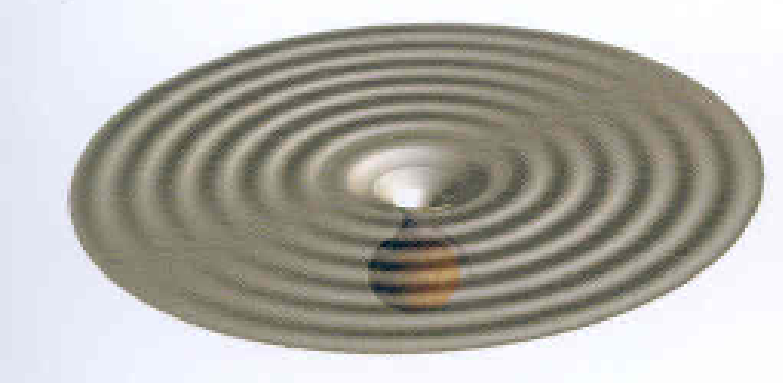

11. Breve História do Tempo Ilustrada, p. 114/5.

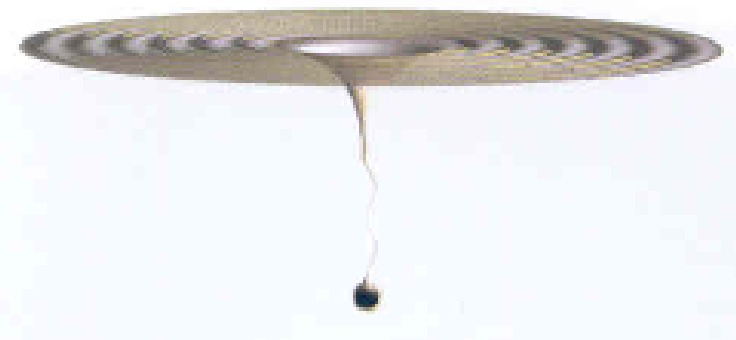

Forma-se uma singularidade

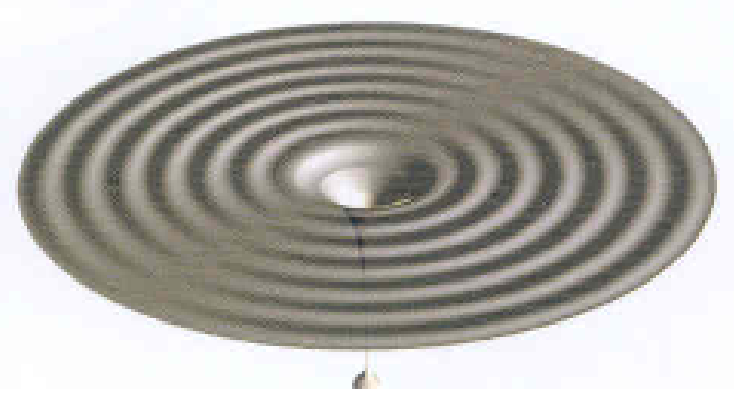

Retomando a idéia de Gleiser, sem entender um pouco a geometria nãoeuclidiana não é possível minimamente entender a teoria da relatividade, porque ela é aplicada, basicamente, em espaços curvos. Os espaços curvos podem ser, como já vimos, de três tipos. Há o universo de curvatura positiva, que corresponde a um universo que se expandirá até certa separação entre as galáxias e então se contrairá de volta até um espaço zero: o chamado universo fechado; há o universo de curvatura zero, que corresponde a um universo que se expande para sempre, diminuindo sua velocidade à medida que faz isso: o dito universo espacialmente plano; e, por fim, o universo de curvatura negativa, que corresponde a um universo em expansão permanente, conhecido como universo aberto.

Ora, os desbravadores da geometria não-euclidiana (George Friedrich Riemann, Nikolayi Ivanovich Lobachevsky e János Bolyai) precisaram criar, para testar suas hipóteses, modelos de superfície de diferentes formatos - uma delas é a pseudo-esfera, onde se encontra a possibilidade da afirmação do postulado de Lobachevsky, ou seja, que por um ponto $\mathbf{P}$ fora de uma reta $\mathbf{r}$ passa mais de uma reta paralela à reta $\mathbf{r}$, conforme a ilustração abaixo. Einstein teve de lutar com as complexidades do espaço curvo, "procurando atribuir a quarta dimensão ao tempo e 
fazendo com que toda a questão, infernalmente complicada, desse certo" (Ferris: 1990, p. 148).

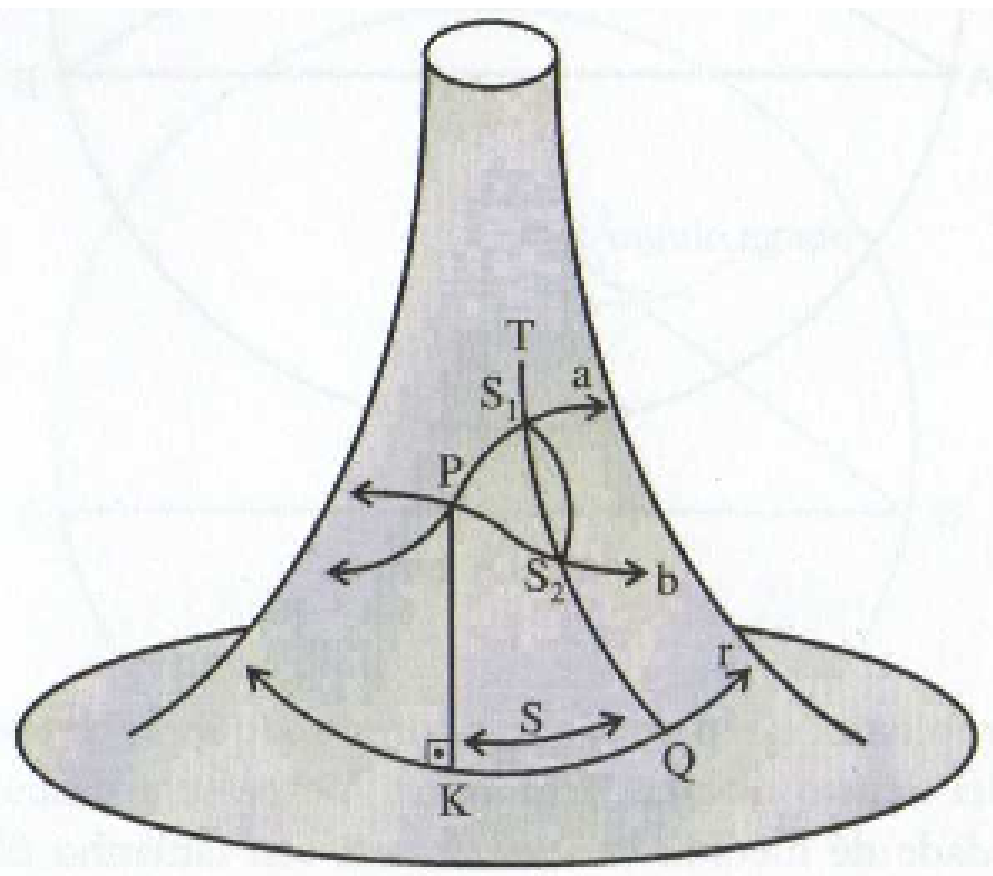

12. Convite às Geometrias não-Euclidianas, p. 05.

A teoria da relatividade é mais bem compreendida a partir da geometria nãoeuclidiana devido ao fato de que o espaço é naturalmente curvo, ou seja, não é um modelo criado para que a tal geometria funcionasse. Mas por que o espaço é naturalmente curvo? Vejamos o que diz Ferris:

Embora suas equações sejam complexas, a concepção geral é extremamente simples. A força da gravidade desaparece e é substituída pela geometria do próprio espaço: a matéria curva o espaço, e o que chamamos de gravitação é apenas a aceleração dos objetos ao deslizarem pelo "tobogã" descrito pelas suas trajetórias no tempo, através das ondulações do espaço. Os planetas deslizam ao longo de paredes internas de uma depressão no espaço criada pelo gordo e maciço Sol; aglomerados de galáxias repousam em buracos espaciais como pepitas na peneira de um garimpeiro (Ferris: 1990, p. 149).

Como podemos observar na gravura seguinte, a matéria é capaz de curvar o espaço, deformando-o; a partir desta constatação, Einstein concluiu que a soma total da massa de todas as galáxias conseguiria deformar o espaço à sua volta. $\mathrm{O}$ resultado disso, segundo Ferris, é um cosmo esférico, quadrimensional, fechado, no qual qualquer observador, de qualquer ponto do universo, presenciaria as galáxias se distanciarem para o espaço longínquo em todas as direções; logo, "não há fim no espaço" (Ferris: 1990, p. 151). 


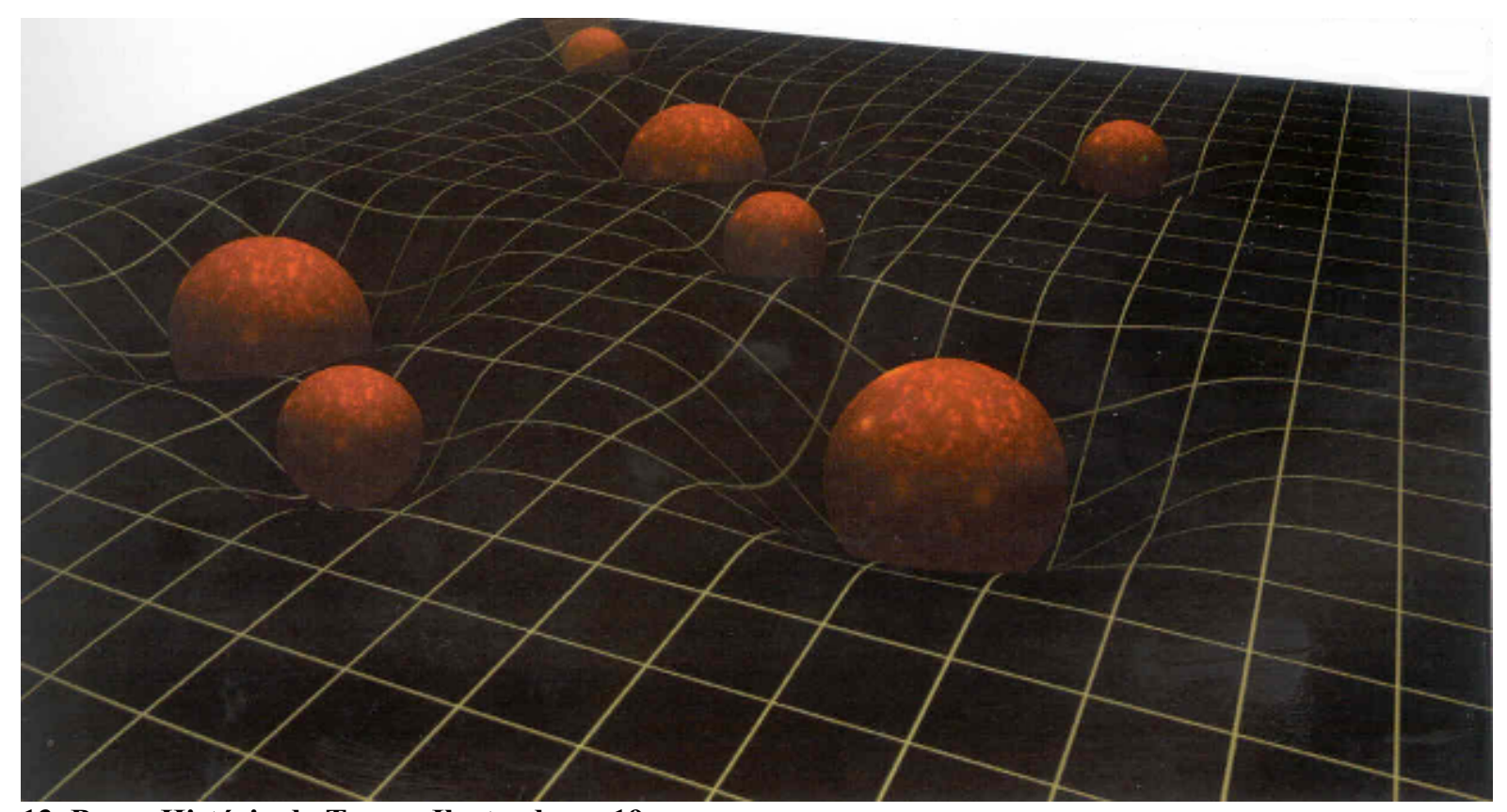

13. Breve História do Tempo Ilustrada, p. 19.

A gravidade, na verdade, é uma distorção do espaço-tempo pela massa e energia nele contidas. Com isso os objetos tentam deslocar-se em linha reta, mas não conseguem; seu percurso parece torto justamente porque o espaço-tempo é curvo. Outro fenômeno muito interessante, causado também pela deformação na geometria do espaço, em função da massa da matéria, é que os raios de luz também têm de seguir as geodésicas no espaço-tempo. Em outras palavras, "o fato de que o espaço é curvo significa que a luz não mais parece estar se deslocando em linhas retas no espaço" (Hawking: 1997, p. 42). Ora, se a luz de uma estrela distante passar próximo do Sol, ela será desviada, fazendo que a estrela apareça em uma posição diferente para um observador situado na Terra. 


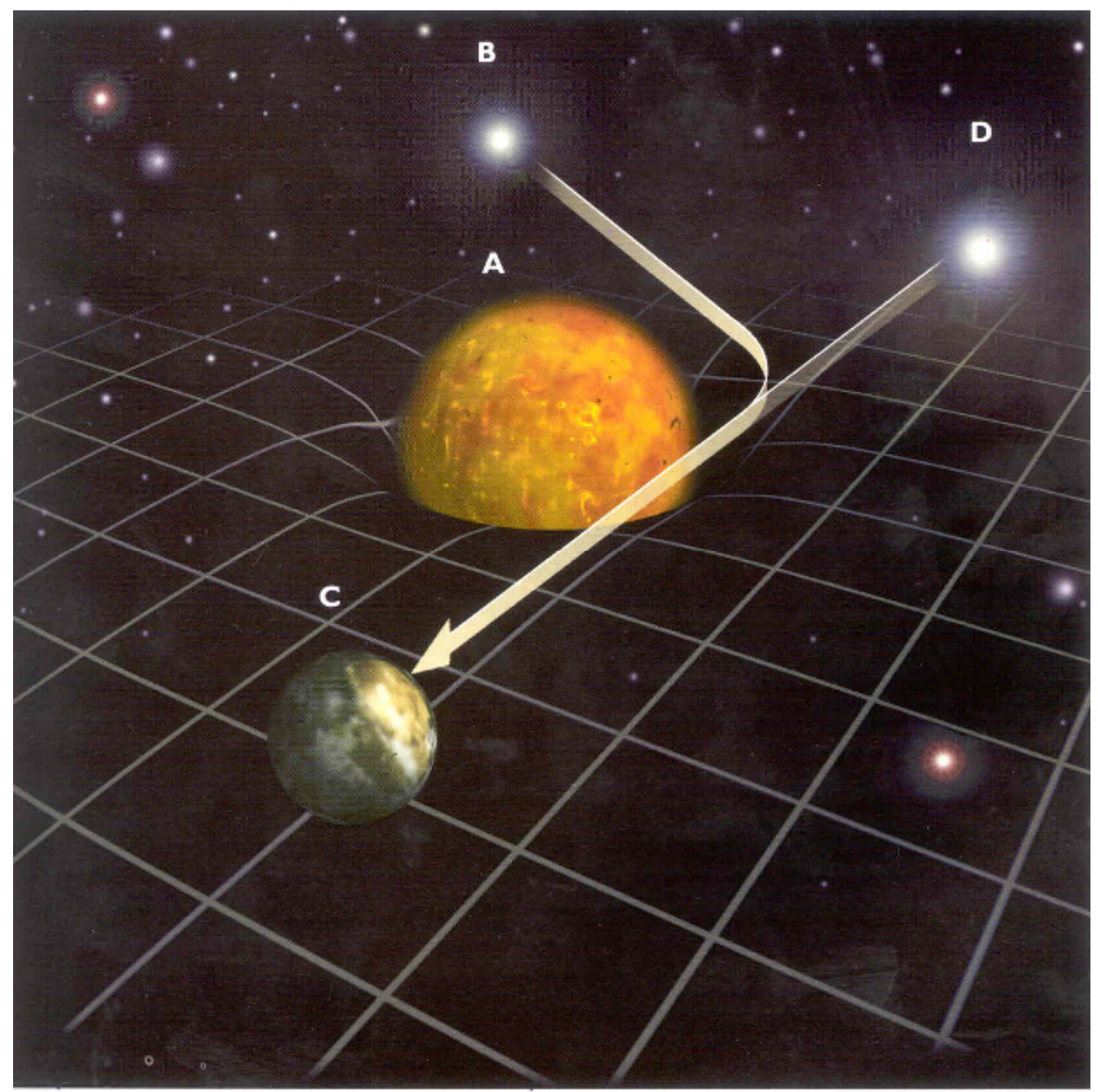

14. Breve História do Tempo Ilustrada, p. 41.

As propriedades do espaço e do tempo não podem ser dadas com exatidão; elas dependem da distribuição e da força gravitacional das massas. Isso quer dizer que o espaço, coberto por matéria de modo uniforme, teoricamente seria uniforme em si, ou seja, em todo lugar ele manteria suas propriedades geométricas. O espaço é uniforme, mas pode ser curvo em algumas partes devido à força gravitacional da matéria. "Um espaço tridimensional pode ser curvo e tornar-se não-euclidiano, como uma superfície bidimensional, isto é, a superfície de uma esfera ou uma pseudoesfera" (Gurevich; Chernin: 1987, p. 21). 
Ora, estudarmos a geometria não-Euclidiana forçosamente nos obriga "(...) a modificar fundamentalmente nossas idéias sobre o espaço e o tempo. Temos que aceitar o fato de que o tempo não é completamente separado e independente do espaço, mas que se combina com ele para formar um objeto chamado espaçotempo" (Hawking: 1997, p. 34). Essa idéia de que o tempo é algo que está intrinsecamente ligado ao espaço - e a geometria não-Euclidiana — é uma idéia que muito nos ajudará a entender a utilização da quarta dimensão na pintura moderna, mas por enquanto vamos verificar a geometria Euclidiana nas Catedrais Góticas e, basicamente, na pintura do Renascimento. 
II

A GEOMETRIA EUCLIDIANA NAS CATEDRAIS GÓTICAS

\section{E NA PINTURA DO RENASCIMENTO}

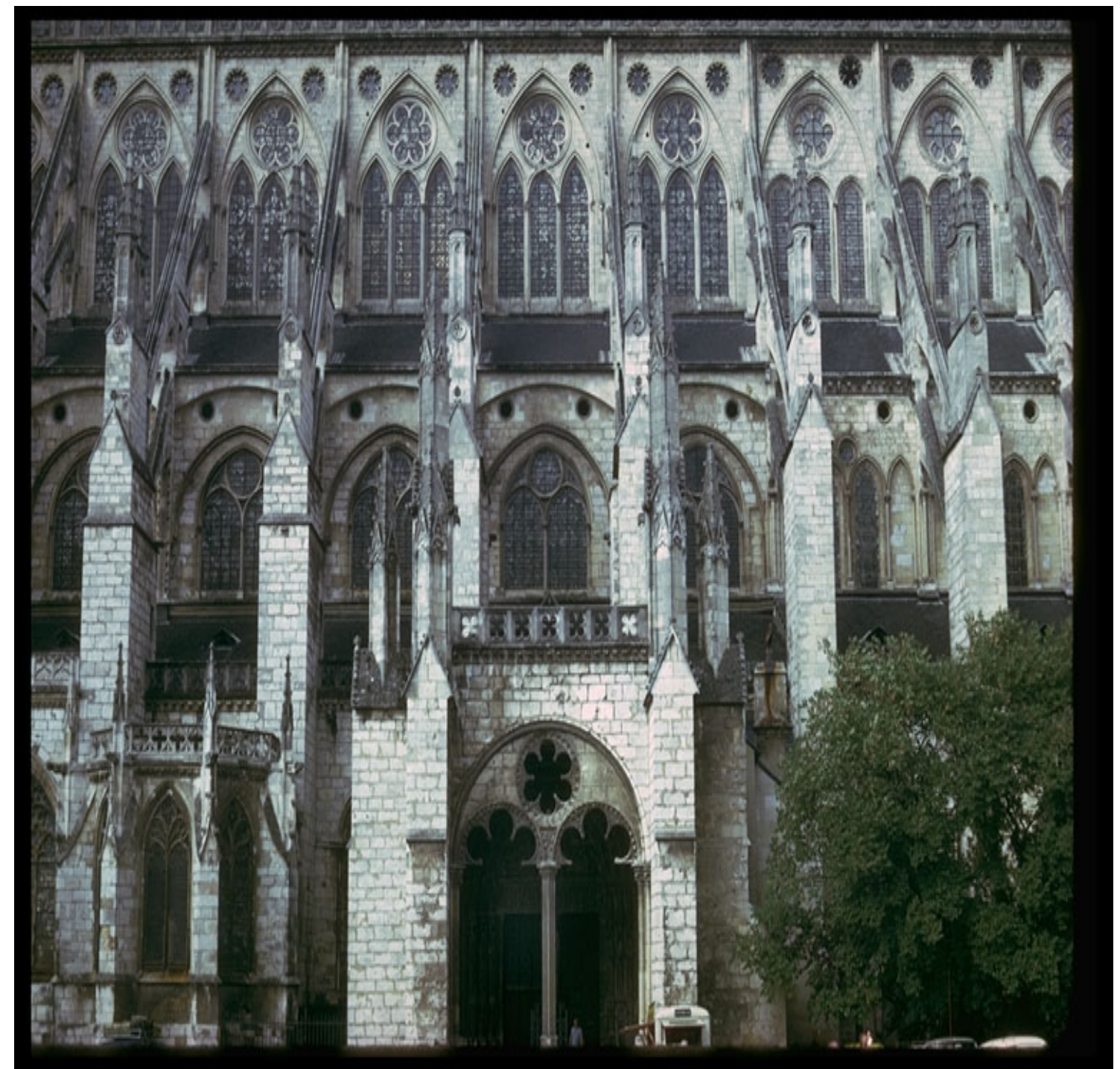

15. Catedral de Bourges (1195).

Fonte: http://web.kyoto-inet.or.jp/org/orion/eng/hst/gothic/bourges.html 


\subsection{Geometria Euclidiana das Catedrais}

As catedrais góticas surgiram da euforia e do misticismo do povo. As primeiras edificações surgiram na França, ao redor de onde se encontra hoje a cidade de Paris. As construções deixaram de trazer esculturas e desenhos

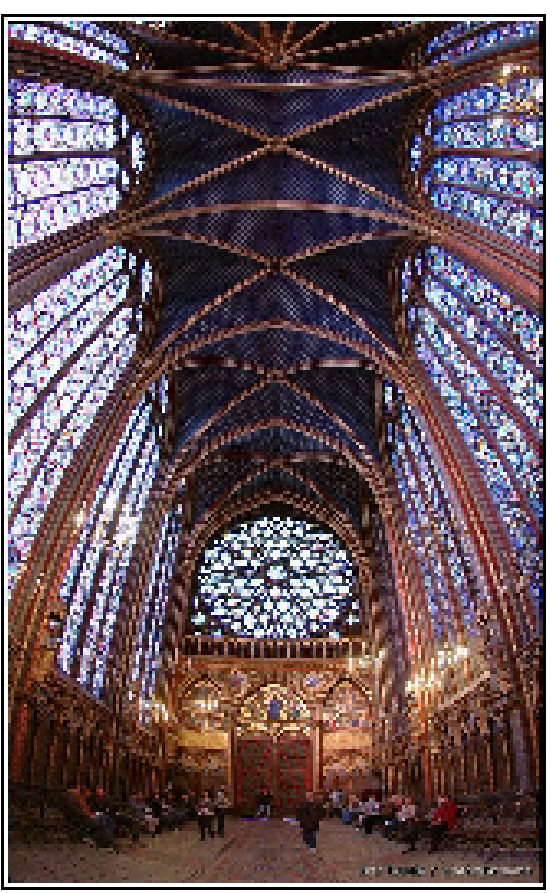

16. Teto de Notre-Dame de Paris tenebrosos, são altas, imponentes, iluminadas, com torres pontiagudas em direção às nuvens. Livre do medo do fim do mundo, o povo é animado por um novo sopro de fé; com isso, as paredes de seus templos devem deixar entrar a luz do Sol em múltiplas cores que lembrem a presença divina.

Nobreza, clero e massa popular competiam em generosidade mística. O objetivo era um só: colaborar para a construção das dispendiosas catedrais. De fato, o estilo gótico é identificado como o período de grandes catedrais, com cuja construção começaram a ser definidos os princípios França, novo centro de poder depois da queda do Sacro Império, em meados do século XII, e terminou aproximadamente no século XIV( embora em alguns países do restante da Europa, como a Alemanha, tenha se entendido até bem depois de iniciado o século XV).

Com o estilo gótico vemos o fim do bárbaro obscurantismo medieval. Não se sabe ao certo a origem da palavra gótico; alguns autores a associam aos godos ou povos bárbaros do Norte. Foi escolhida pelos italianos do Renascimento para descrever essas descomunais construções que, em sua opinião, escapavam aos critérios bem proporcionados da arquitetura.

Foi nas universidades, sob o severo postulado da escolástica - Deus como Unidade Suprema e Matemática -, que se estabeleceram as bases dessa arte eminentemente teológica. A verticalidade das formas, a pureza das linhas e o recato da ornamentação na arquitetura foram transportados também para a pintura e a escultura. O gótico implicava uma renovação das formas e técnicas de toda a arte com o objetivo de expressar a harmonia divina. 
A arquitetura gótica se apoiava nos princípios de um forte simbolismo teológico, fruto do mais puro pensamento escolástico: as paredes eram a base espiritual da Igreja, os pilares representavam os santos, e os arcos e os nervos eram o caminho para Deus. Além disso, nos vitrais pintados e decorados se ensinava ao povo, por meio da mágica luminosidade de suas cores, as histórias e relatos contidos nas Sagradas escrituras.

A construção gótica, de modo geral, diferenciou-se pela elevação e desmaterialização das paredes, assim como pela especial distribuição da luz no espaço. Tudo isso foi possível graças a duas das inovações arquitetônicas mais importantes desse período: o arco em ponta, responsável pela elevação vertical do edifício, e a abóbada cruzada, que veio permitir a cobertura de espaços quadrados, curvos ou irregulares.

Os arcos de meia circunferência usados nas abóbadas das igrejas românicas faziam que todo o peso da construção fosse descarregado sobre as paredes. Isso obrigava a um apoio lateral resistente: pilares maciços, paredes mais espessas, poucas aberturas para fora. O espaço para as janelas era bem reduzido e o interior da igreja escurecia. Mas o espírito do povo pedia luz e grandiosidade. Então, como consegui-las? O arco em meia circunferência foi substituído por arcos ogivais ou arcos cruzados, dividindo o peso da abóbada central e fazendo-o ser descarregado sobre vários pontos, simultaneamente; assim, poderia ser usado material mais leve, tanto para a abóbada como para as bases de sustentação. Resultado: em lugar dos sólidos pilares, esbeltas colunetas passaram a receber o peso da abóbada.

O restante do peso foi distribuído por pilares externos. Estes, por sua vez, remetem o peso aos contrafortes - torres pontiagudas e muito trabalhadas, que substituem as maciças pilastras românicas, com a mesma função. As torres dão mais altura e majestade à catedral. As paredes, perdendo sua importância como base de sustentação, passam a ser feitas com um dos materiais mais frágeis de que se dispunha: o vidro. Surge a desejada luminosidade. Grandes e feéricos vitrais coloridos ilustram em desenhos cenas da vida cristã. A magia dos vitrais góticos, que filtram a luz do Sol, enche a igreja de uma claridade mística que lembra a presença divina.

O sistema de suportes constituídos de pilares cantonados e fasciculados, pequenas colunas cilíndricas e nervos, junto com os arcobotantes, tornou a parede mais leve, até seu quase total desaparecimento. As janelas ogivais e as rosetas 
acentuaram ainda mais a transparência da construção. A intenção era criar no visitante a impressão de um espaço que se alçava infinitamente até o céu.

\subsubsection{Construções Geométricas}
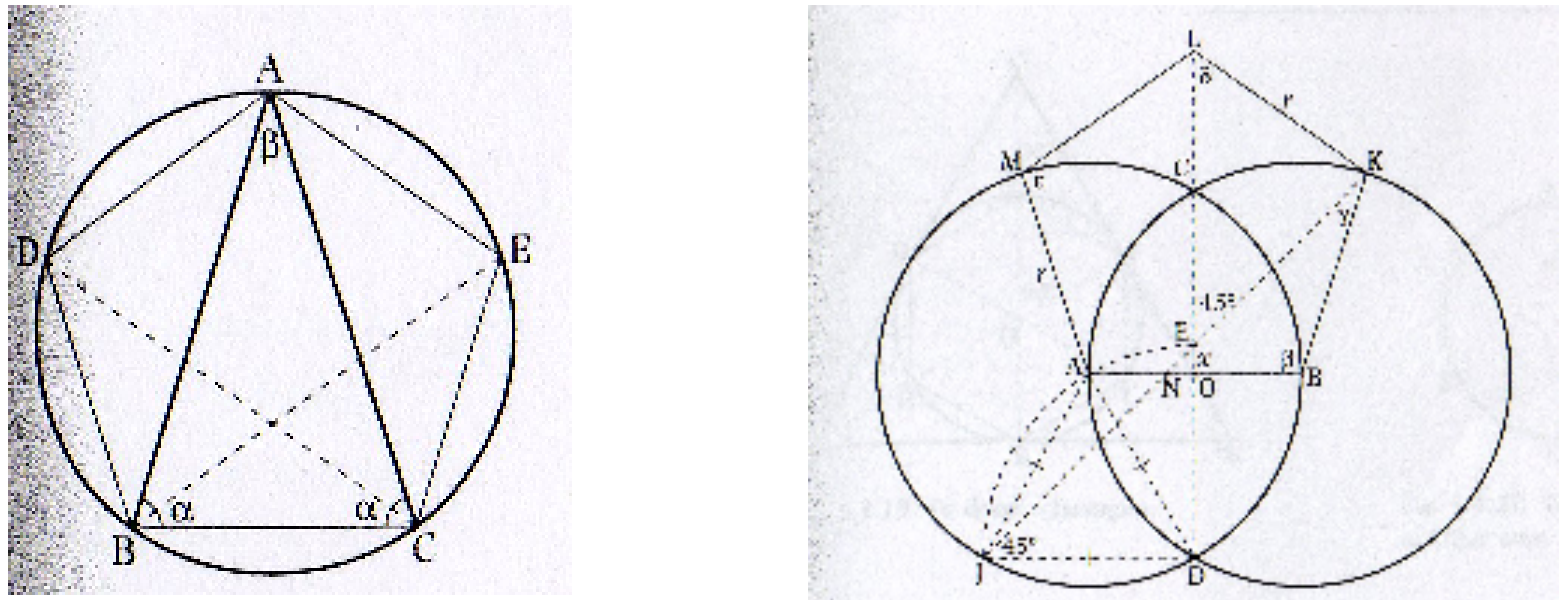

17. Poliedros

A partir das construções de Euclides outras variações foram feitas para obter polígonos inscritos em um círculo, cuja utilização pode ser vista em muitas edificações góticas. Então, por exemplo, Euclides (Heilbron: 2003, p. 225) diz que, para traçar um pentágono eqüilátero, devemos circunscrever um triângulo isósceles em um círculo e, em seguida, determinar a bissetriz dos ângulos (figura acima, lado esquerdo). Os pontos $A, B, C, D$ e $E$ são os vértices do pentágono. Os indivíduos

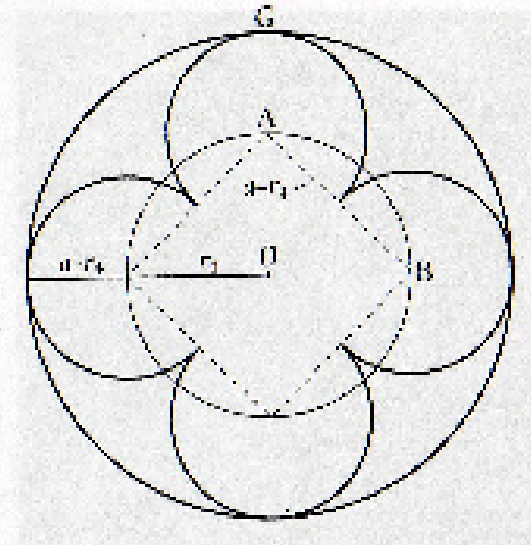

18. Desenho de uma Rosácea. encarregados de cortar os blocos de pedra para as construções medievais precisavam de meios mais rápidos e práticos na construção de polígonos. Em função disso, acabavam desenvolvendo variações das proposições de Euclides. A figura acima à direita é um bom exemplo dessas variações. Traçam-se dois círculos iguais a partir de A e B;

em seguida, liga-se C e D; com abertura D e O, corta-se o círculo da esquerda obtendo-se, assim, o ponto J e o ponto E; prolongase JE até intersectar o outro círculo em $\mathrm{K}$; com centro em $\mathrm{K}$, traça-se um arco que 
cortará CD em L; e com centro em L traça-se um arco que cortará o primeiro círculo em M. Então ABKLM é o pentágono desejado.

Podemos verificar a presença de muitos exemplos de polígonos nas janelas das catedrais góticas. Na figura acima é possível verificarmos a estrutura, a esquematização que está por trás de cada construção. O centro de cada círculo está ligado por linhas retas; o resultado é um quadrado inscrito em um círculo imaginário. Segundo Heilbron, é exatamente este tipo de construção geométrica que encontramos na Catedral de Sées (ca. 1330) e na Catedral de Amiens (início do século XIV), a primeira com quatro lóbulos e a segunda com oito lóbulos.

llustração 19: Catedral de Amiens.

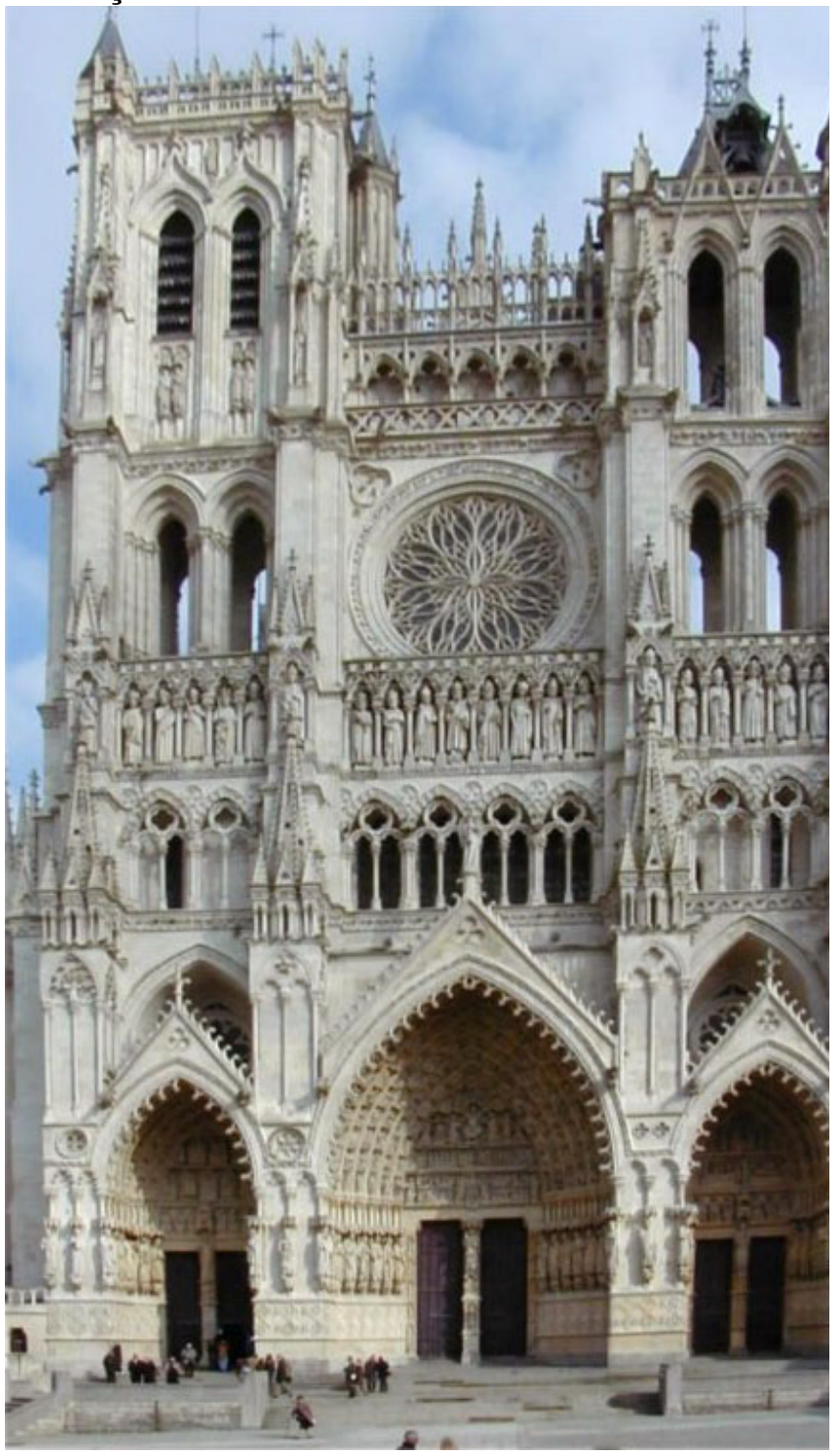

Fonte: http://pt.wikipedia.org/wiki/Amiens.
Ilustração 20: Rosácea da Catedral de Amiens.

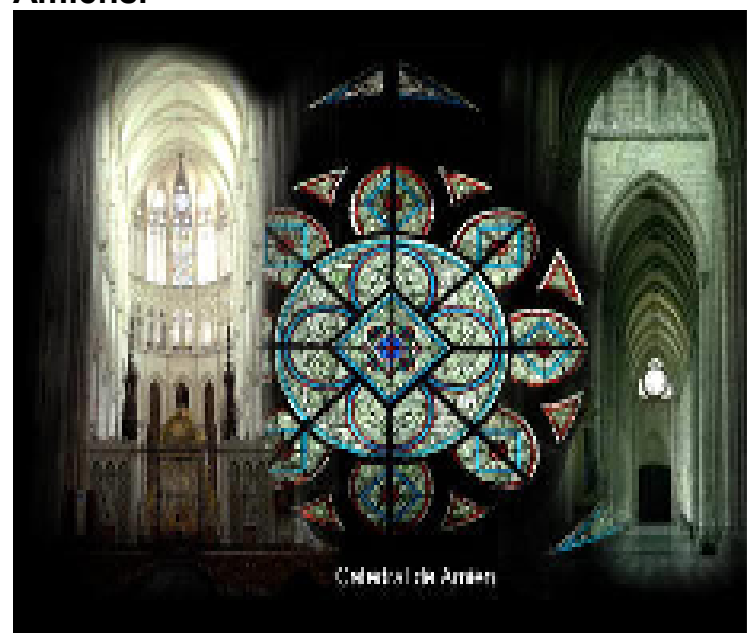

Fonte:

http://www.learn.columbia.edu/Mcahweb/Amie ns.

llustração 21.

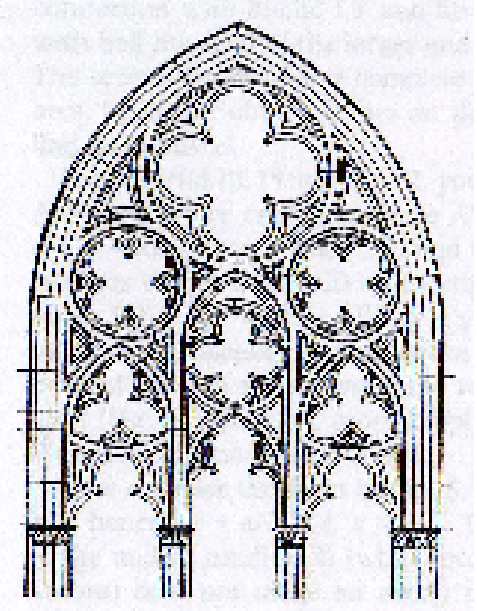




\subsubsection{As Janelas das Catedrais}

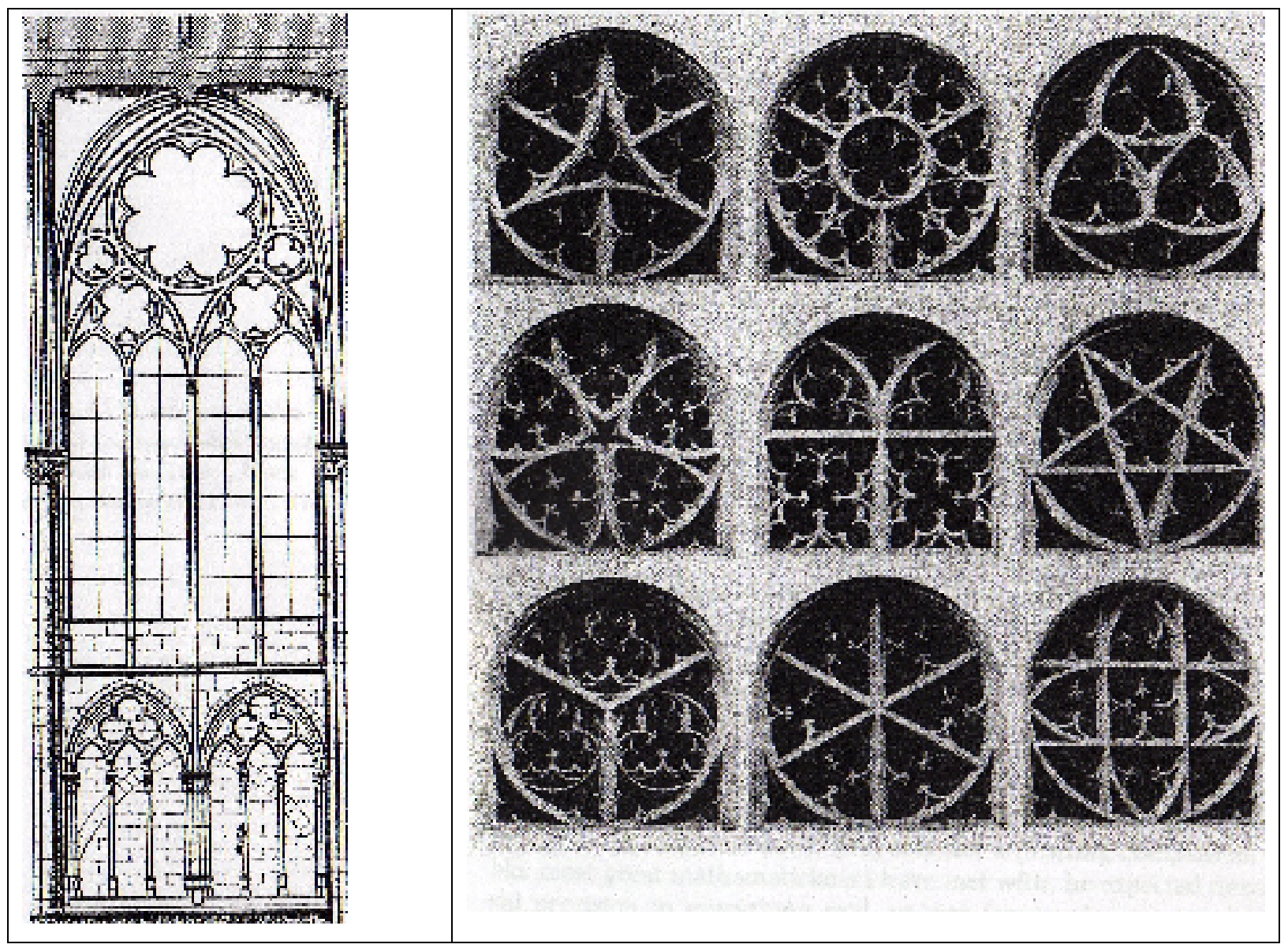

22. Desenhos de Rosáceas.

É observando as janelas das catedrais que percebemos com clareza a utilização da geometria euclidiana. Na figura ao lado, por exemplo, vemos uma janela fortemente marcada pela simetria, que ajuda a reforçar a concepção metafísica da Idade Média.

As janelas circulares ficam em cima ou entre os arcos, encaixando-se de modo a tocar três arcos circulares. Outro ponto interessante a ser observado é o modo como os círculos tangenciam os arcos e entre si, tornando as construções cada vez mais complexas. Na figura ao lado o arco maior se subdivide em dois e os dois menores em outros dois menores ainda, sendo que na parte de baixo o maior subdivide-se em três. O procedimento para efetuar as tangências não é, aparentemente, muito complicado. Vejamos a partir das figuras seguintes. 

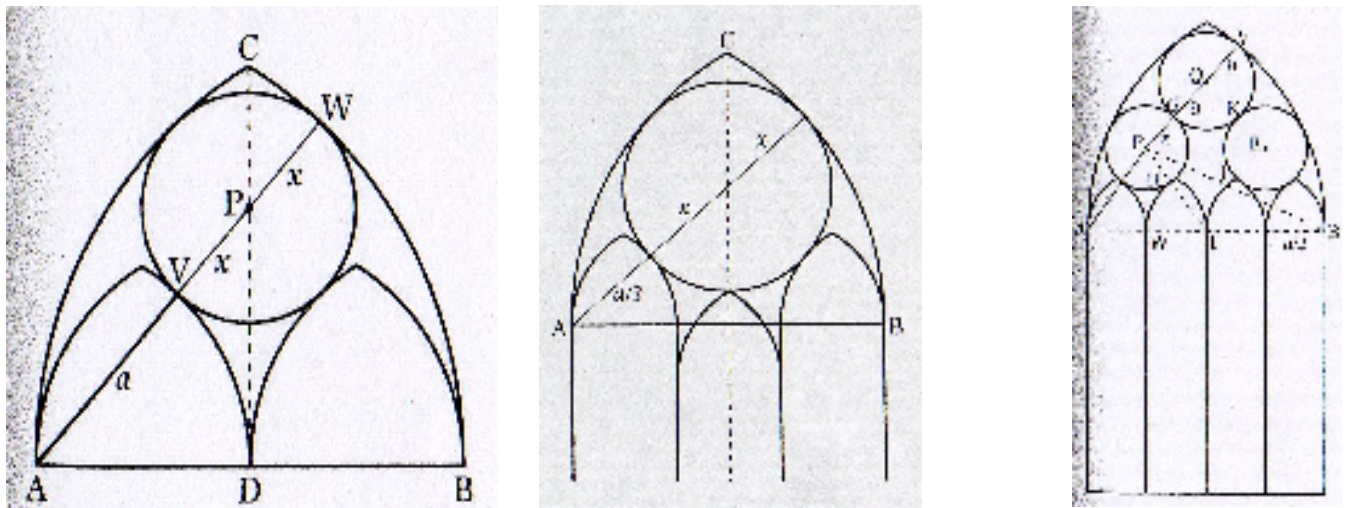

23. Construções de Arcos.

No primeiro exemplo, o arco maior foi dividido em dois menores; o procedimento seguinte é dividir o segmento $A B$ determinando, assim, o ponto $D$; com isso podemos construir os dois arcos menores. Em seguida devemos determinar o ponto $\mathrm{P}$ em CD; para tanto, é necessário traçarmos a bissetriz a partir de A e prolongá-la até encontrar o arco oposto. Com essas formações já é possível traçarmos um círculo inscrito que tangenciará os dois arcos menores. Nos outros exemplos temos, sucessivamente, o arco maior dividido em três e, por último, no terceiro exemplo, o arco maior dividido em quatro arcos menores. 


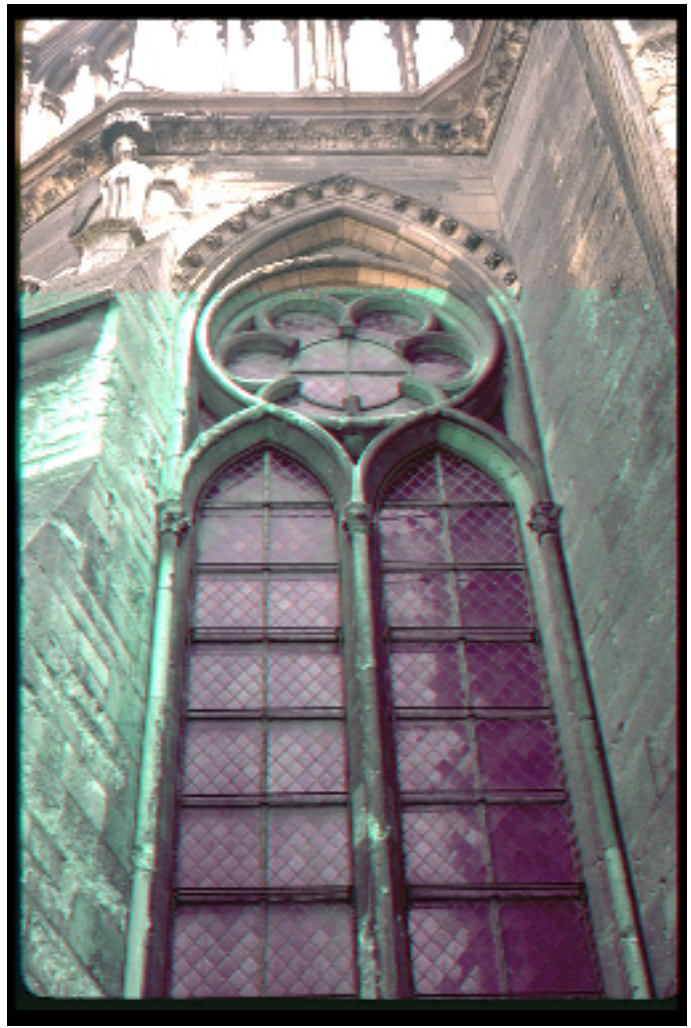

24. Janela da Catedral de Reims. http://pt.wikipedia.org/wiki/Catedral_de_Notr e-Dame_de_Reims

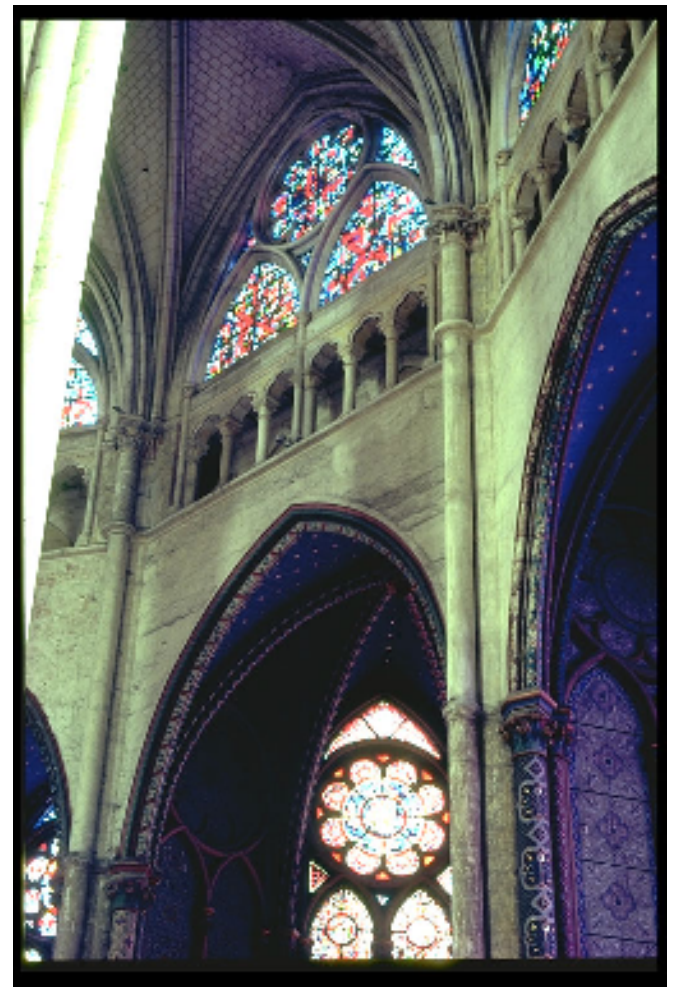

25. Catedral de Beauvais (Séc. XIII-XVII). http://pt.wikipedia.org/wiki/Beauvais

Nas fotos acima, a primeira da catedral de Reims e a segunda da catedral de Beauvais, vemos alguns exemplos de arcos maiores divididos em dois arcos menores; acima dos quais vemos um círculo que tangencia tanto os arcos maiores como os menores. Ora, se por um lado não vemos a aplicação sistematizada da geometria nas pinturas, nas Catedrais, por outro lado, a geometria Euclidiana foi utilizada abundantemente, promovendo, inclusive, variações das construções originais.

\subsubsection{As Rosáceas}

A rosácea, como podemos perceber, é um elemento arquitetonico ornamental muito usado no auge do período gótico. Um elemento característico desse período artístico é a rosácea, uma abertura circular onde um desenho geométrico de bandas 
de pedra é preenchido com vidro colorido. Ela transmite, através da luz e da cor, o contacto com a espiritualidade e a ascensão ao sagrado. As cores são fortes, acentuando o realismo da representação pela combinação de variados tons da mesma cor. Sua localização é sobre o portal da da fachada principal. A decoração é feita no sentido radial, estilizando a representação das pétalas de uma rosa; está ligada à história bíblica de uma figura que surge no centro da composição. Os temas mais retratados são Virgem com o Menino, cenas da vida de Cristo e dos apóstolos e as mais variadas histórias bíblicas.

Segundo consta na Wikepedia, a rosácea teve origem no oculus romano, que foi se transformando em janela durante o período românco. Com o desnvolvimento do gotico e suas inovações técnicas e artísticas, meados do século XII, foi possível distribuir o peso pelas abóbodas e pelos contrafortes possibilitando a abertura de grandes vãos de parede, permitindo a entrada da luz. Com isso a rosácea acaba por aumentar consideravelmente as suas dimensões, e em meados do século XIII já pode abranger a largura total da nave.

As primeira rosáceas surgem sob um arco circular, como, por exemplo, a que aparece na Catedrald e Notre-Dame de Paris. Conforme pode ser verificado abaixo. 


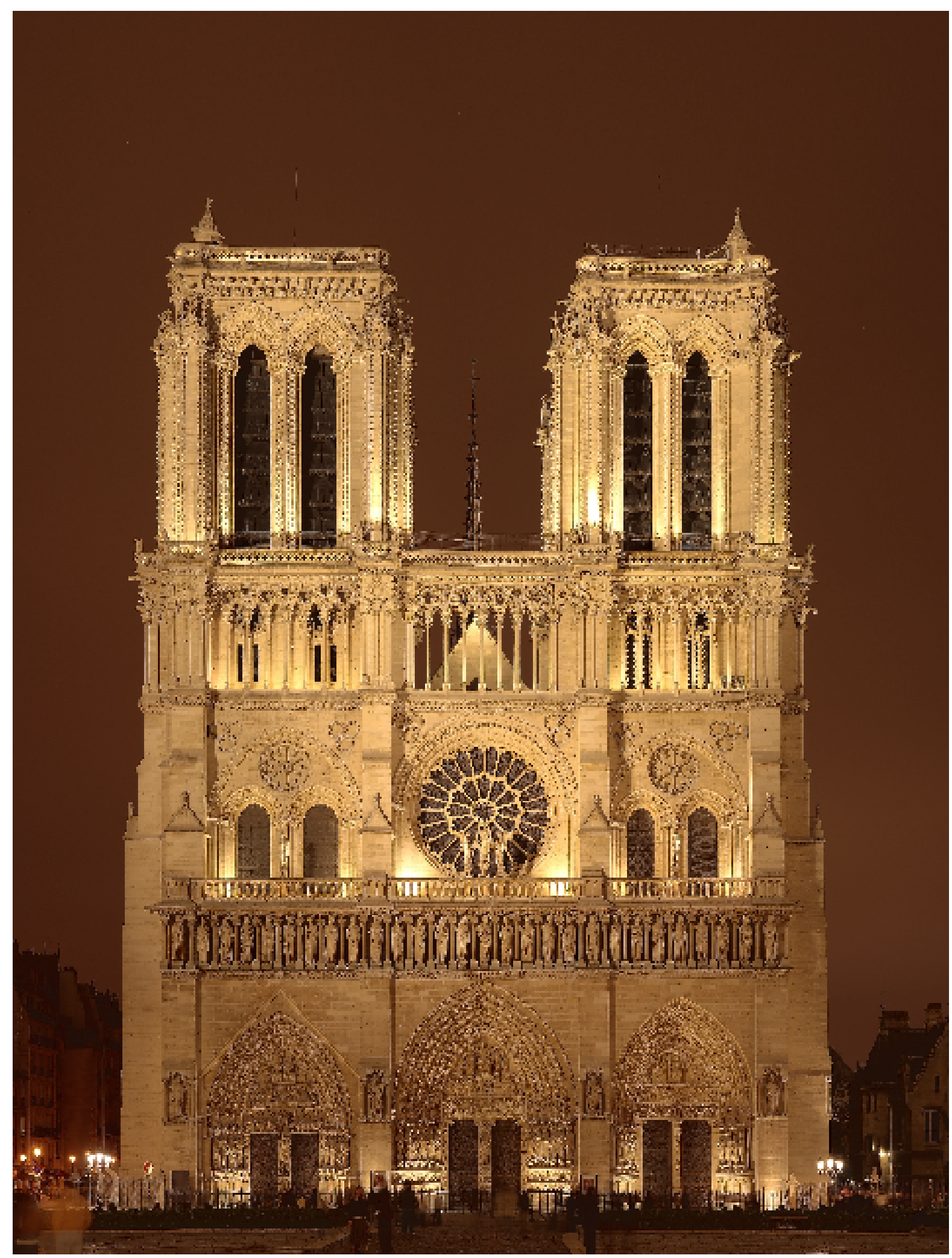

26. Notre-Dame de Paris. Construída de 1163 a 1250.

http://pt.wikipedia.org/wiki/Catedral_de_Notre-Dame_de_Paris 
Mais tarde as rosáceas aparecem sob um arco quebrado, como se observa Catedral de Reims.

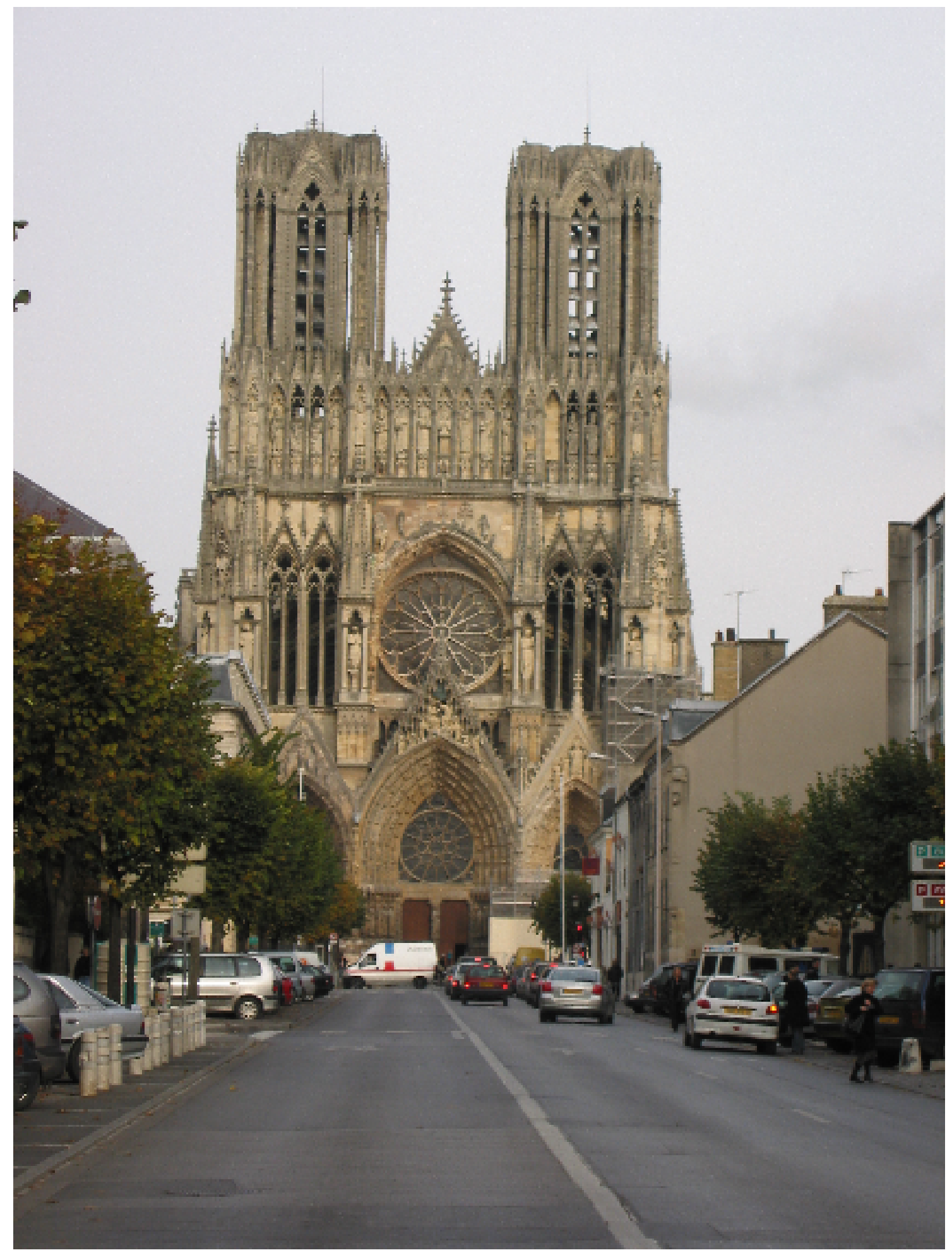

27. Catedral de Reims 
No gótico flamejante as subdivisões de pedra da rosácea passam a ter um desenho rendilhado de curvas extremamente intrincado, as chamadas traceria ${ }^{7}$.

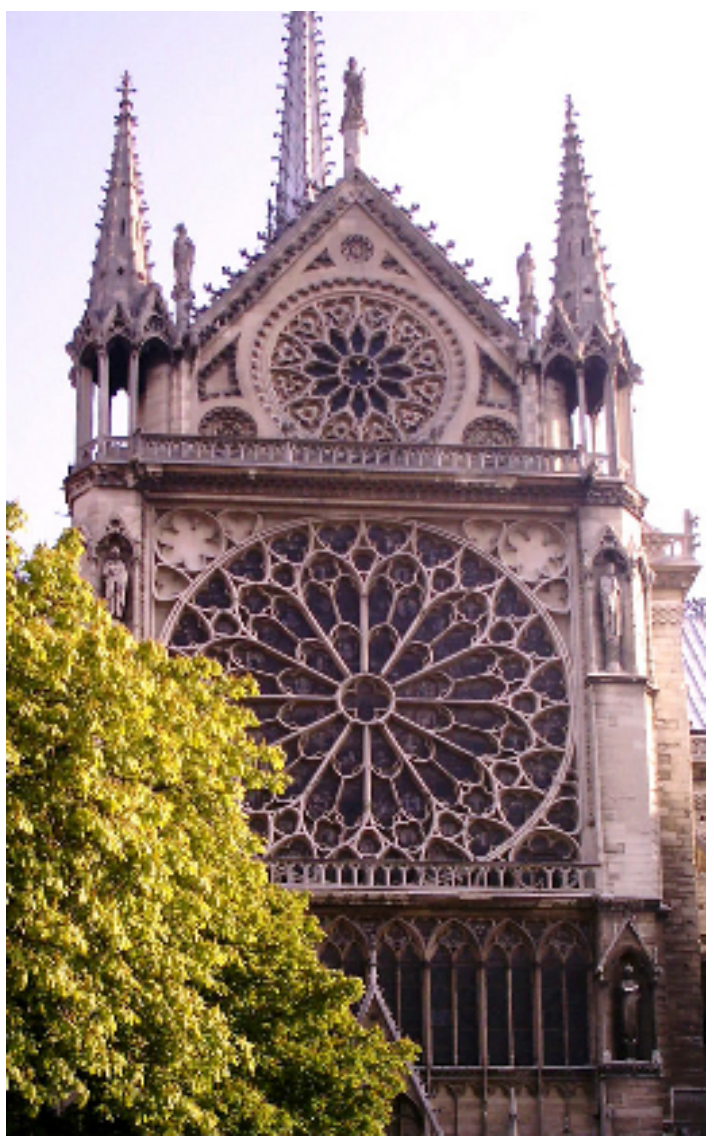

28. Notre-Dame de Paris (Sul) - Terceria.

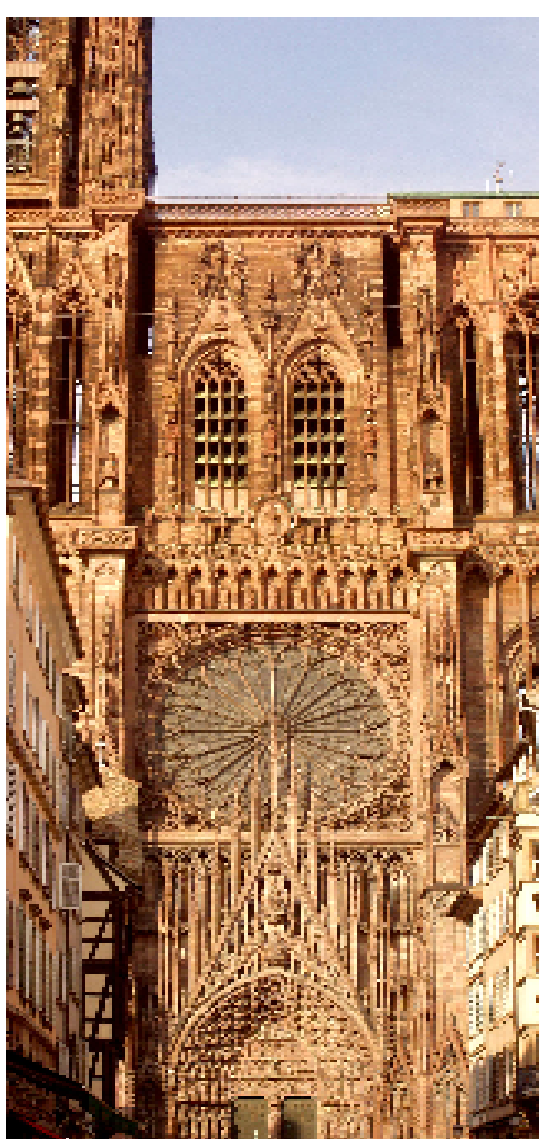

29. Notre-Dame de Strasbourg Terceria.

\subsubsection{A Catedral da Sé}

Percorrendo alguns pontos da cidade de São Paulo é possível notar a presença de estruturas geométricas que são muito próximas dos arcos e das rosáceas encontradas nas grandes catedrais da Europa. A catedral da Sé um bom exemplo!

Como consta no wikipedia, a história da Catedral da Sé inicia-se em 1589 com a construção de uma igreja matriz na Vila de São Paulo de Piratininga; a igreja foi terminada em 1616. Em 1745 essa igreja foi demolida e substuída por uma nova em estilo barroco, terminada por volta de 1764. A modesta igreja também foi demolida em 1911.

A catedral foi uma iniciativa de Dom Duarte Lepoldo e Silva, primeiro arcebispo de São Paulo. A construção iniciou em 1913 pelas mãos do aquiteto alemão Maximilian Emil Hehl, inspirado nas grandes catedrais medievais 
eurpopéias. Segundo wikipedia, os trabalhos foram lentos, e a inauguração da nova catedral ocorreu somente em 1954, com as torres ainda inacabadas, mas a tempo para a celebração do quarto centenário de São Paulo. As torres foram terminadas somente em 1967.

A catedral da Sé é a maior igreja de São Paulo, com 111 metros de comprimento, 46 de largura, duas torres com 92 metros de altura e uma enorme cúpula. A igreja tem forma de cruz latina, com cinco naves e um transepto com cúpula sobre o cruzeiro. A fachada, dotada de um portal principal e uma grande rosácea, é flanqueada por duas altas torres.

\subsubsection{O Estilo Neogótico}

A Catedral da Sé é neogótica, estilo que predominante no Brasil; porém a cúpula é inspirada em estruturas renascentistas, como o célebre domo da Catedral de Florença.

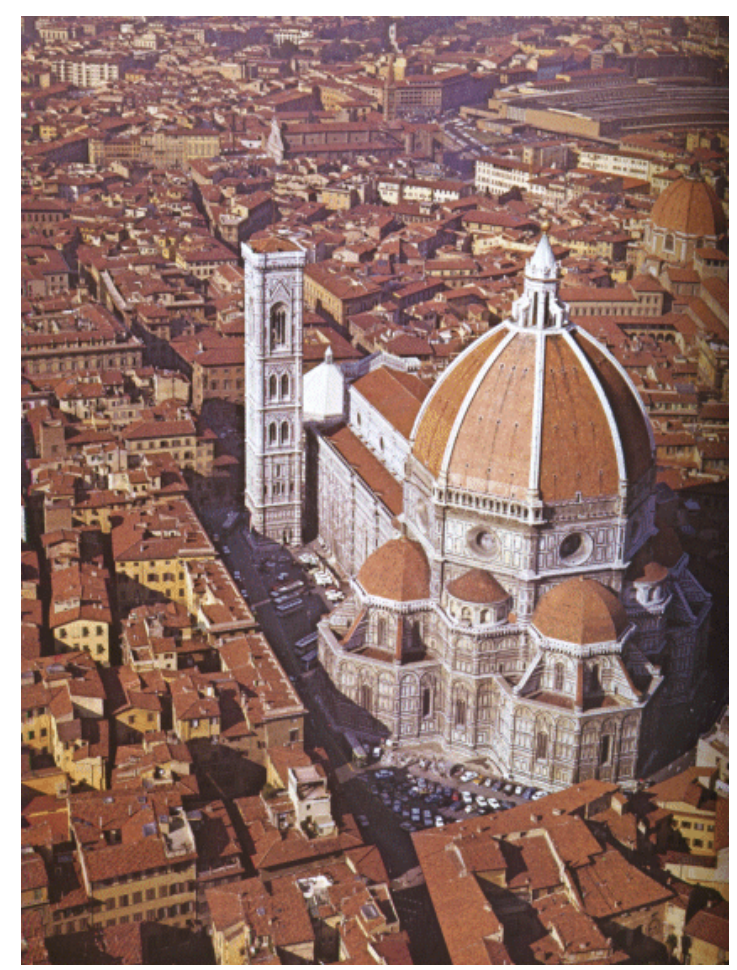

30. 


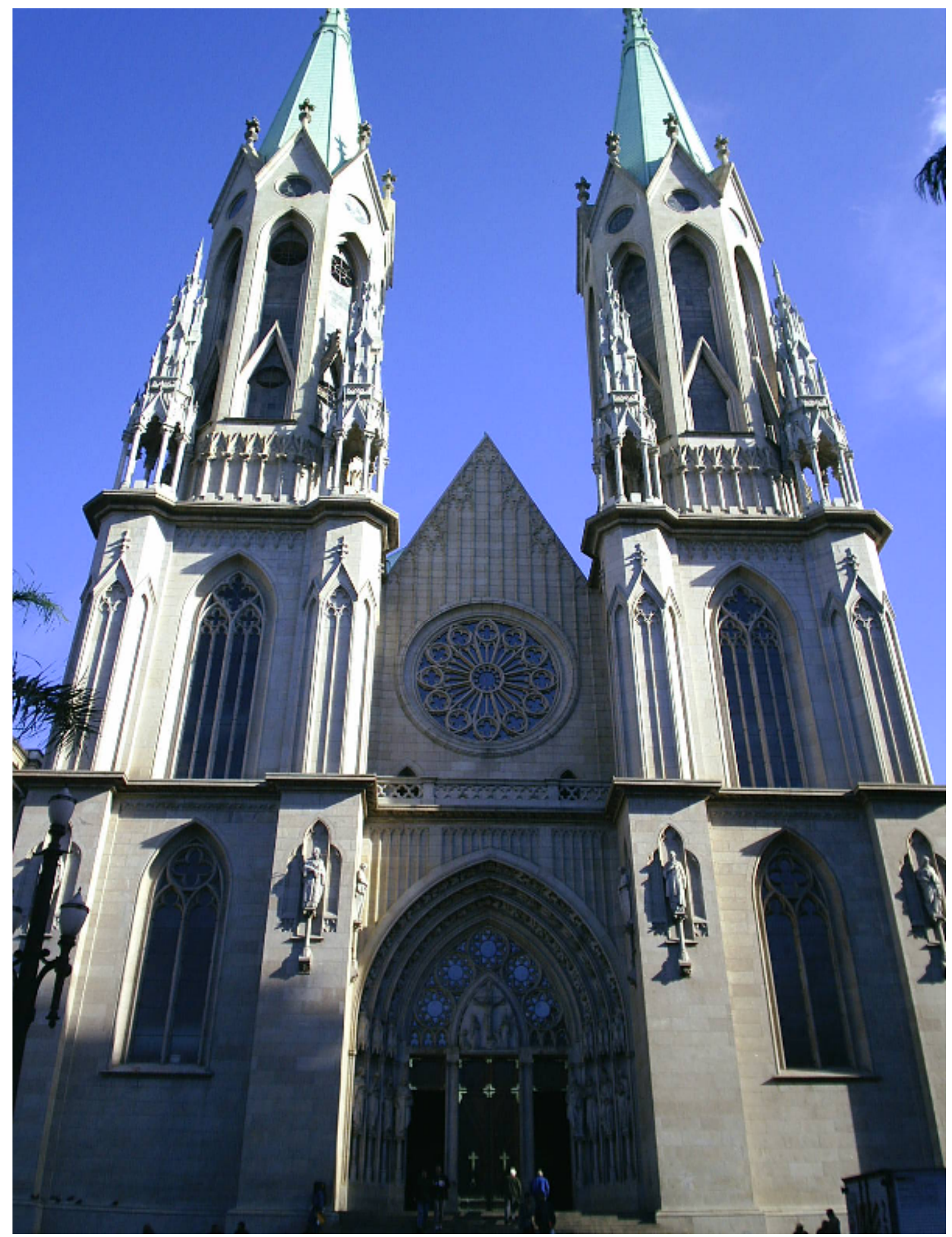

31. Catedral da Sé. 
Podemos observar, a partir da fachada central, algumas semelhanças entre a rosácea que está na parte de cima da Catedral da Sé e a que está na parte central da Catedral de Notre-Dame de Paris.

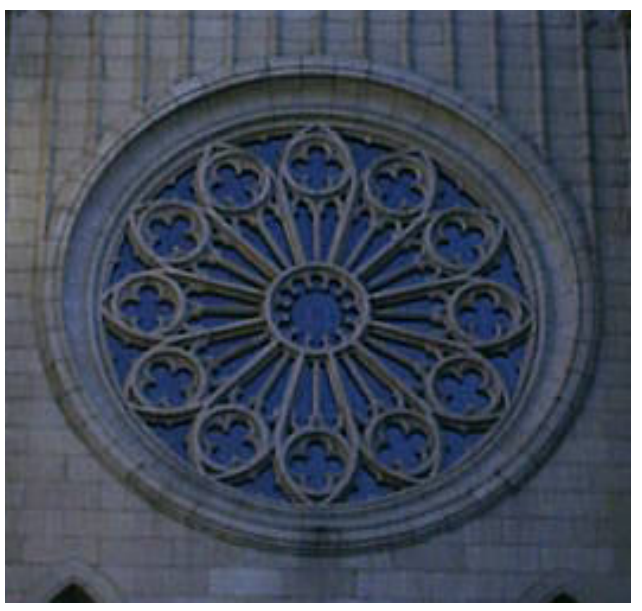

32. Detalhe da rosácea da Catedral da Sé.

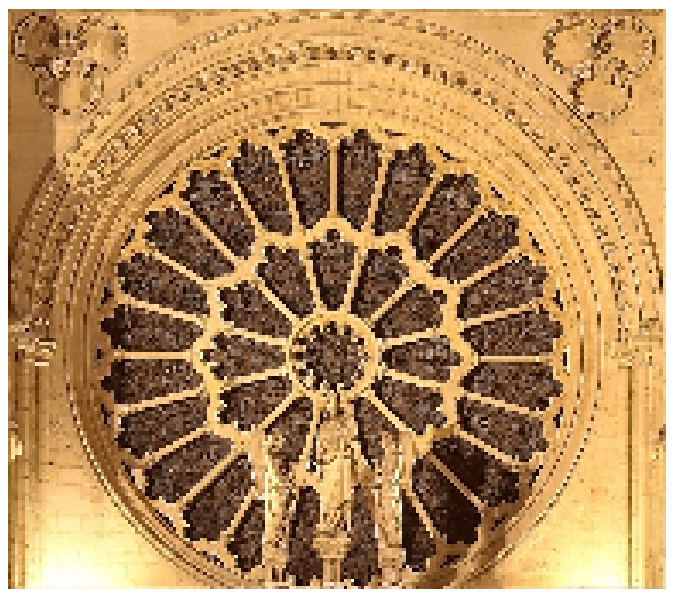

33. Detalhe da rosácea da Catedral de NotreDame.

Notemos que na rosácea da Catedral da Sé há um círculo dividido em doze partes iguais, gerando, assim, doze círculos menores. Dentro desses círculos o artista optou por dividir um polígono em quatro partes iguais ${ }^{8}$. Já na rosácea da Catedral de Notre-Dame, de Paris, temos, primeiramente, uma divisão em doze, e em seguida uma divisão em vinte e quatro partes; ou seja, o artista duplica o espaço, porém não altera a figura geométrica inicial.

Num primeiro momento a rosácea da Catedral de Notre-Dame parece ser mais bela, com mais harmonia e até mais complexa. Porém, se nos voltarmos, cuidadosamente, para rosácea da Catedral da Sé, perceberemos que, embora muito mais simples no conjunto - em relação à edificação - as soluções são tão complexas quanto as de Notre-Dame.

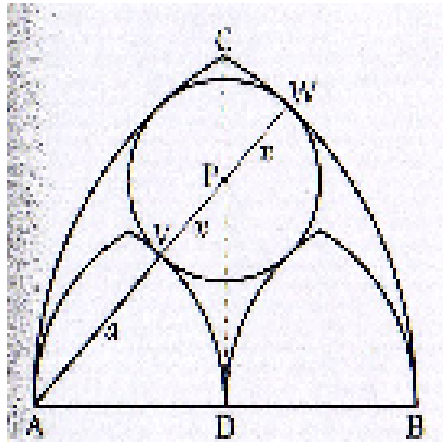

34. Arco Ogival.

Notemos, a partir da figura ao lado, que o artista trabalhou, no final de cada arco, inscrevendo um círculo em cada arco. Repetiu o mesmo processo de acordo com o número de vezes necessário, ou seja, doze vezes. O que há falta na rosácea da Catedral da Sé é a riqueza de detalhes, na parte externa, que há na Catedral de Notre- 
Dame, de Paris.

Se nos atentarmos para o fato de que nas construções de rosáceas o princípio utilizado é o mesmo para a construção de arcos nas janelas das catedrais, a geometria utilizada ainda é a geometria de Euclides. Pois,

\subsection{A Importância das Imagens para os Leigos}

Como a Igreja tinha de encontrar espaço para toda congregação que se reunia para o serviço religioso, aconteceu que "as igrejas não foram modeladas pelos templos clássicos, mas pelo tipo de vastos salões de reunião que nos templos clássicos eram conhecidos pelo nome de 'basílicas', o que significa aproximadamente 'salões reais"' (Gombrich: 1985, p. 94). A questão de como decorar essas basílicas foi um tema muito difícil de ser resolvido, em função da utilização de imagens. Vejamos as palavras do próprio Gombrich:

Num ponto quase todos os primeiros cristãos concordavam: não devia haver estátuas na casa do Senhor. As estátuas pareciam-se demais com aquelas imagens esculpidas de ídolos pagãos que a Bíblia condenava. Colocar uma figura de Deus ou de um de Seus santos no altar parecia inteiramente fora de questão. Pois como os míseros pagãos que tinham se convertido recentemente à nova fé apreenderiam a diferença entre suas antigas crenças e a nova mensagem, se vissem tais estátuas nas igrejas? Poderiam facilmente pensar que uma estátua "representa" realmente Deus, tal como pensavam antes que uma estátua de Fídias representava Zeus. Assim, eram capazes de achar até mais difícil compreender a mensagem do Deus TodoPoderoso, Invisível e Uno, a cuja semelhança tinham sido feitos. Mas, embora todos os cristãos devotos pusessem objeções às grandes estátuas copiadas da vida real, suas idéias sobre pinturas diferiam bastante. Alguns as consideravam úteis porque ajudavam a congregação a recordar os ensinamentos que haviam recebido e mantinham viva a memória desses episódios sagrados. Esse ponto de vista foi principalmente adotado na parte latina, ocidental, do Império Romano. O papa Gregório, o Grande, que viveu no final do século VI d.C., seguiu essa orientação. Lembrou àqueles que eram contra todas as pinturas que muitos membros da Igreja não podiam ler nem escrever, e que, para ensiná-los, essas imagens eram tão úteis quanto os desenhos de um livro ilustrado para crianças. Disse ele: "A pintura pode fazer pelos analfabetos o que a escrita faz para os que sabem ler" (Gombrich: 1985, p. 95).

Se por um lado houve, portanto, a preocupação de que as imagens poderiam dificultar a compreensão da nova mensagem por parte dos recém-convertidos, por outro houve o entendimento de que as pinturas ajudariam a recordar e manter vivos muitos episódios sagrados. A relação que o artista passaria a estabelecer entre 
aquilo que sentia e aquilo que expressaria iria satisfazer um propósito muito bem determinado, uma vez que passaria a ser de outra ordem: a espiritual. A idéia do artista passaria a ter relação direta com as Idéias do intelecto divino. Segundo Panofsky, a "relação que o espírito do artista estabelece entre suas representações interiores e suas obras exteriores pode muito bem ser comparada àquela que o intelecto divino mantém entre as Idéias que lhe são interiores e o mundo criado por ele; de modo que, mesmo que o artista não possua a Idéia como tal, pode-se não obstante pensar que ele está de posse de 'uma quase idéia' (segundo a expressão literal utilizada certa vez por Tomás de Aquino)" (Panofsky: 1994, p. 40). Como postula Gombrich, essa intervenção do papa Gregório foi muito importante para a história da arte, pois sua sentença seria citada repetidamente sempre que as pessoas atacavam o uso de imagens nas igrejas. Mas houve muitas restrições no tipo de arte utilizada: a história tinha de ser contada da maneira mais clara possível, e tudo que pudesse desviar a atenção dessa finalidade deveria ser omitido. No começo os artistas ainda utilizavam os métodos narrativos que tinham sido desenvolvidos pela arte romana; não obstante, passaram a se concentrar cada vez mais no que era estritamente essencial. Portanto, enquanto na Grécia a arte era feita à medida do homem, e na Roma imperial à do imperador, a arte da cristandade seria feita a partir de Deus. 


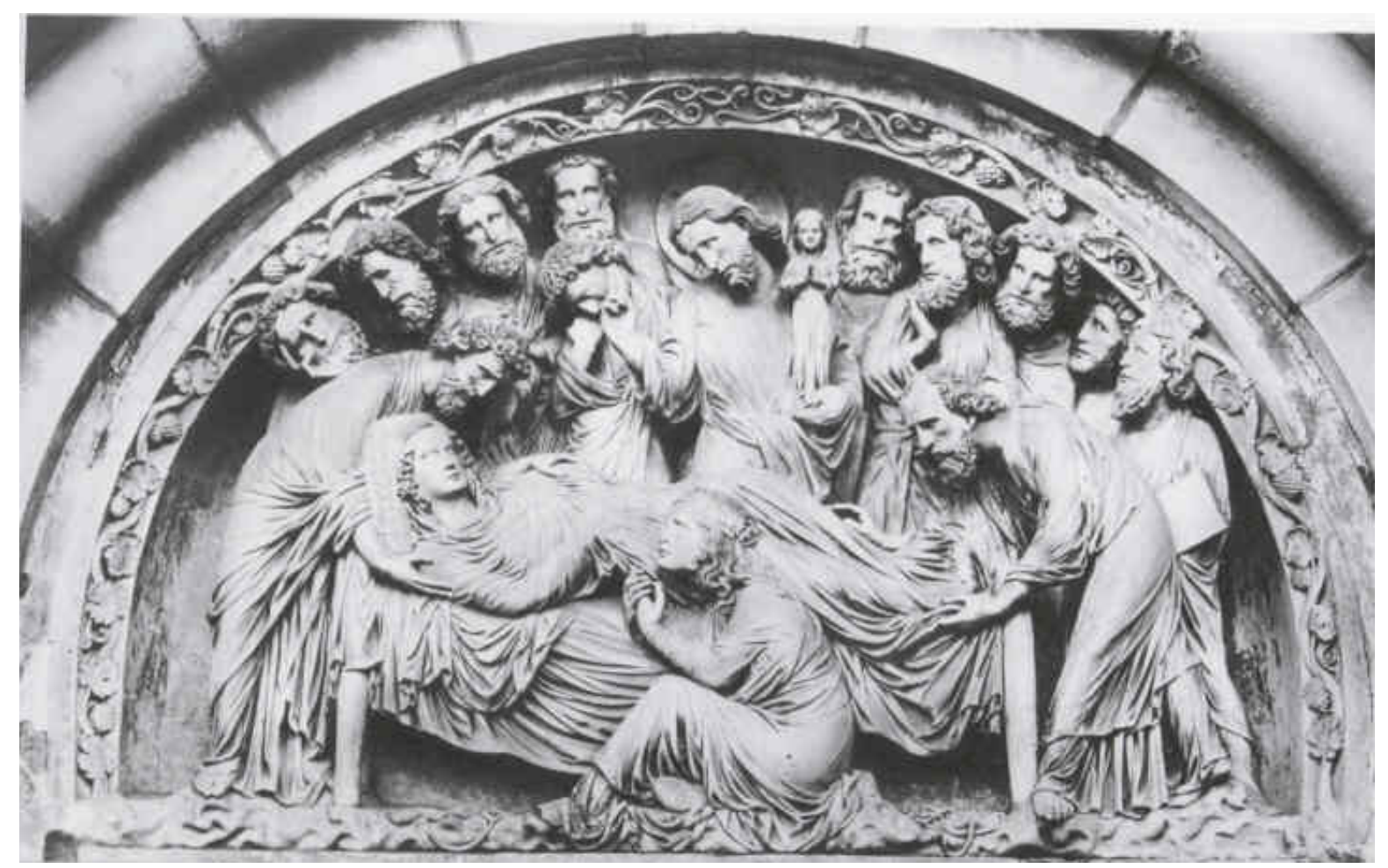

35. A Morte da Virgem - tímpano do portal Sul. Catedral de Estrasburgo, c. 1220. Janson: 1989, p. 30

Assim como na Grécia, os artistas começaram a observar a natureza, não para copiá-la, mas para aprender com ela como fazer uma figura ter um aspecto convincente. Porém, há uma grande diferença entre a arte do templo e a da catedral. Como observa Gombrich, os artistas gregos do século V a.C. estavam interessados em como realizar a imagem de um belo corpo. De acordo como o pesquisador, todos os métodos e estratagemas passariam a ser apenas um meio para atingir um determinado fim. Logo, havia uma grande diferença entre a arte dos templos e a arte das catedrais. A intenção principal era contar uma história sagrada de um modo mais comovente e mais convincente. "Não contar apenas por contar, mas para transmitir uma mensagem, e para alívio e edificação dos fiéis. A atitude do Cristo olhando para a Virgem agonizante era claramente mais importante para o artista do que a habilidosa reprodução de seus músculos" (Gombrich: 1985, p. 144).

Enfim, segundo observa Janson, as roupagens, a expressão facial, os movimentos e os gestos "tem um sabor clássico". "O que Ihe dá cunho gótico, mais do que românico, é a ternura profundamente sentida que impregna toda a cena. Há o elo de uma emoção comum a unir as figuras, uma capacidade de comunicação pelo olhar e pelo gesto tais como nunca tínhamos encontrado" (Janson: 1989, p. 
320) Podemos notar, por fim, que a cena segue o critério de organização semicircular porque o espaço é semicircular.

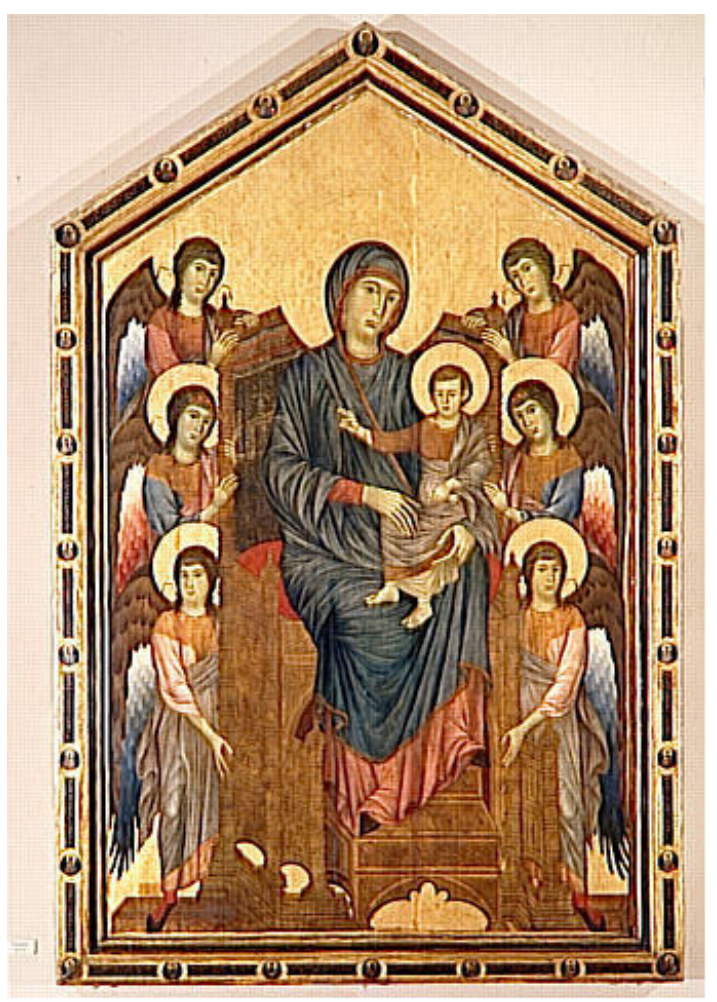

36.

A figura acima, além da verticalidade muito forte, apresenta alguns signos que são característicos da iconografia medieval. A Península Itálica ao Sul manteve forte influência da arte bizantina, presa a uma concepção iconizada da imagem: hieratismo, forma rígida e majestosa imposta por uma tradição invariável; frontalidade, representação das imagens sempre de frente; tricomatismo, a utilização do azul, dourado e do ocre; isocefalia, todas as cabeças de iam série da mesma altura; isodactilia, todos os dedos de uma mesma com o esmo tamanho; e a hierarquia dos espaços, ou seja, o destaque variando das figuras mais sagradas para as menos sagradas (Sevcenko:1988, p. 27).

Mas, segundo Hauser, os aspectos que são considerados característicos da arte medieval - o desejo de simplificação e estilização, a renúncia à profundidade espacial e à perspectiva, o tratamento arbitrário das proporções e funções corporais - são, na verdade, características da fase inicial da Idade Média, o que podemos 
facilmente perceber na figura acima. O único elemento que perpassa toda a Idade Média é uma concepção transcendental do mundo, ou seja, uma cosmovisão assente em bases metafísicas (Hauser: 2000, p. 123). Para que essa concepção transcendental do mundo vingasse, Santo Agostinho teve de substituir o espírito impessoal que reinava com o Neoplatonismo pelo Deus pessoal do cristianismo.

\subsubsection{Os Princípios da Esquematização Planimétrica}

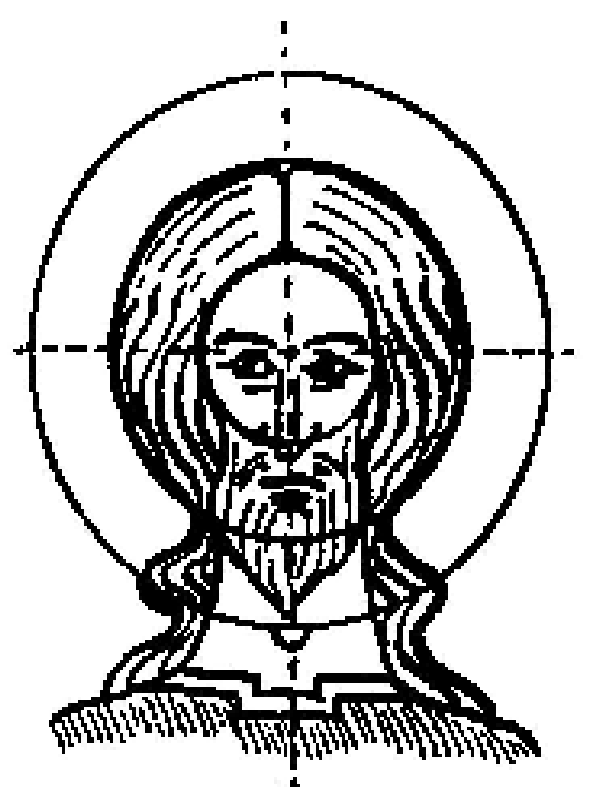

37. Cabeça de Cristo.

À primeira vista, pode-se ter a impressão de que não houve preocupação com questões teóricas voltadas para a arte, em função de uma concepção metafísica do mundo. Os artistas da Idade Média, na verdade, adotaram a teoria das proporções a partir do princípio de esquematização planimétrica - em outras palavras, aceitavam o fato de que as partes do corpo se realçavam pela sua própria natureza, utilizando, para isso, o sistema de módulo ou de unidade.

As dimensões do corpo como aparecem num plano - tudo o que estivesse fora do plano não era levado em conta - eram expressas em comprimentos de cabeças, ou, mais exatamente, de face (...). Assim, segundo o Manual do pintor do Monte Atos, uma unidade era destinada ao rosto, três ao torso, estimada em 1 1/3 unidades" (Panofsky: 1979, p. 110). 
De acordo com as observações de Panofsky (1979, p. 116), a teoria das proporções ocupou-se em determinar as medidas dos detalhes das cabeças em termos do sistema de módulos, tomando como medida-padrão o comprimento do nariz. Sendo assim, o comprimento do nariz é igual à altura da testa e da parte inferior da cabeça; à altura da parte superior da cabeça; à distância entre a ponta do nariz e o canto dos olhos, e, finalmente, ao comprimento total do pescoço. Por conseguinte, os artistas desse período não se preocupavam tanto - diferentemente dos gregos que, apesar de entenderem o escorço, e dos pintores helenísticos, que eram engenhosos na criação da ilusão da profundidade, ignoravam as leis matemáticas segundo as quais os objetos parecem diminuir de tamanho quando se afastam de nós - com rigorosas leis matemáticas. Pois foi só com Giotto, que modificou toda a concepção de pintura, que a velha maneira bizantina de representação foi superada. Porém, como observa Gombrich, seria errôneo acreditar que a arte italiana separou-se da do resto da Europa de um dia para o outro. 


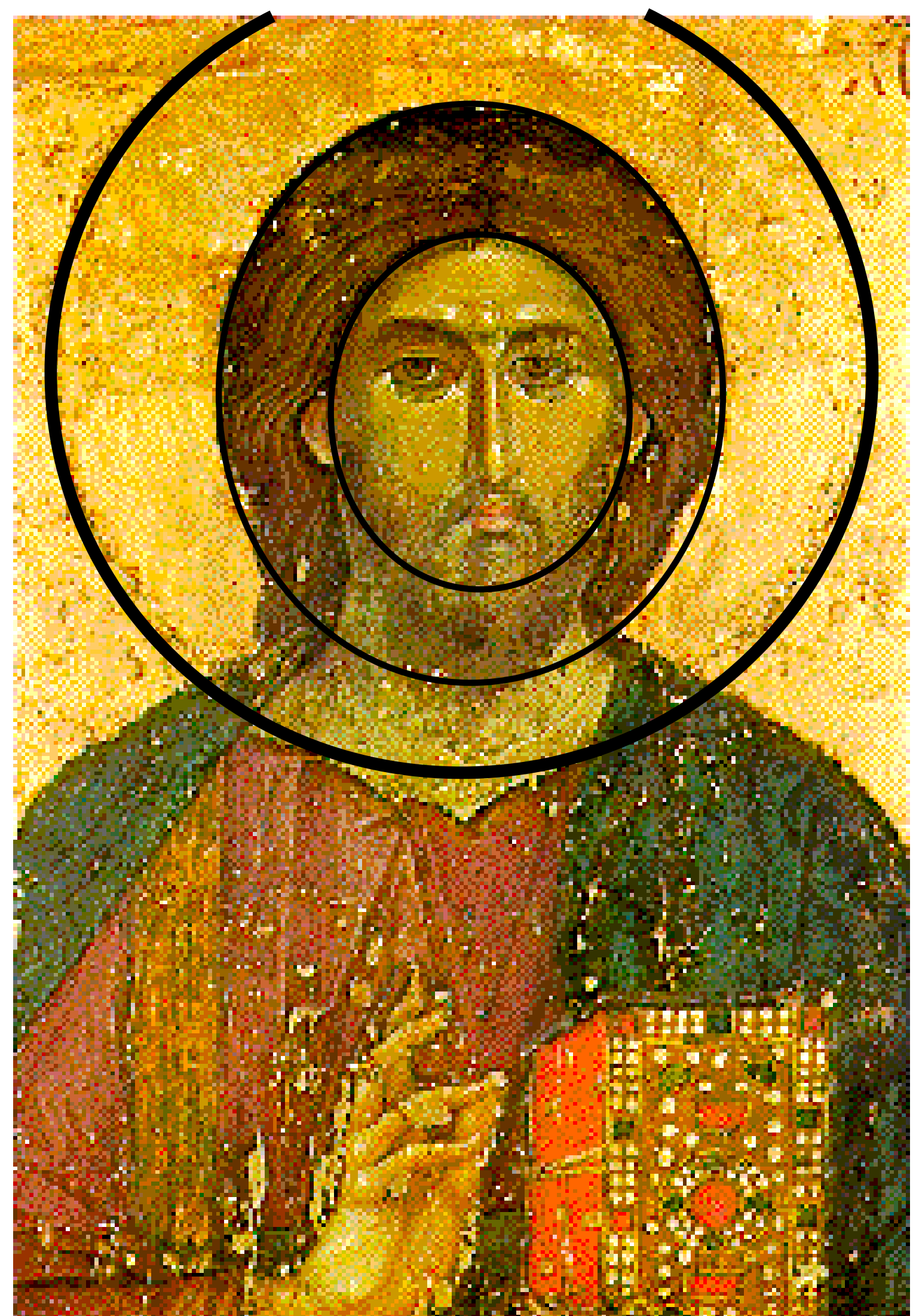

38. 


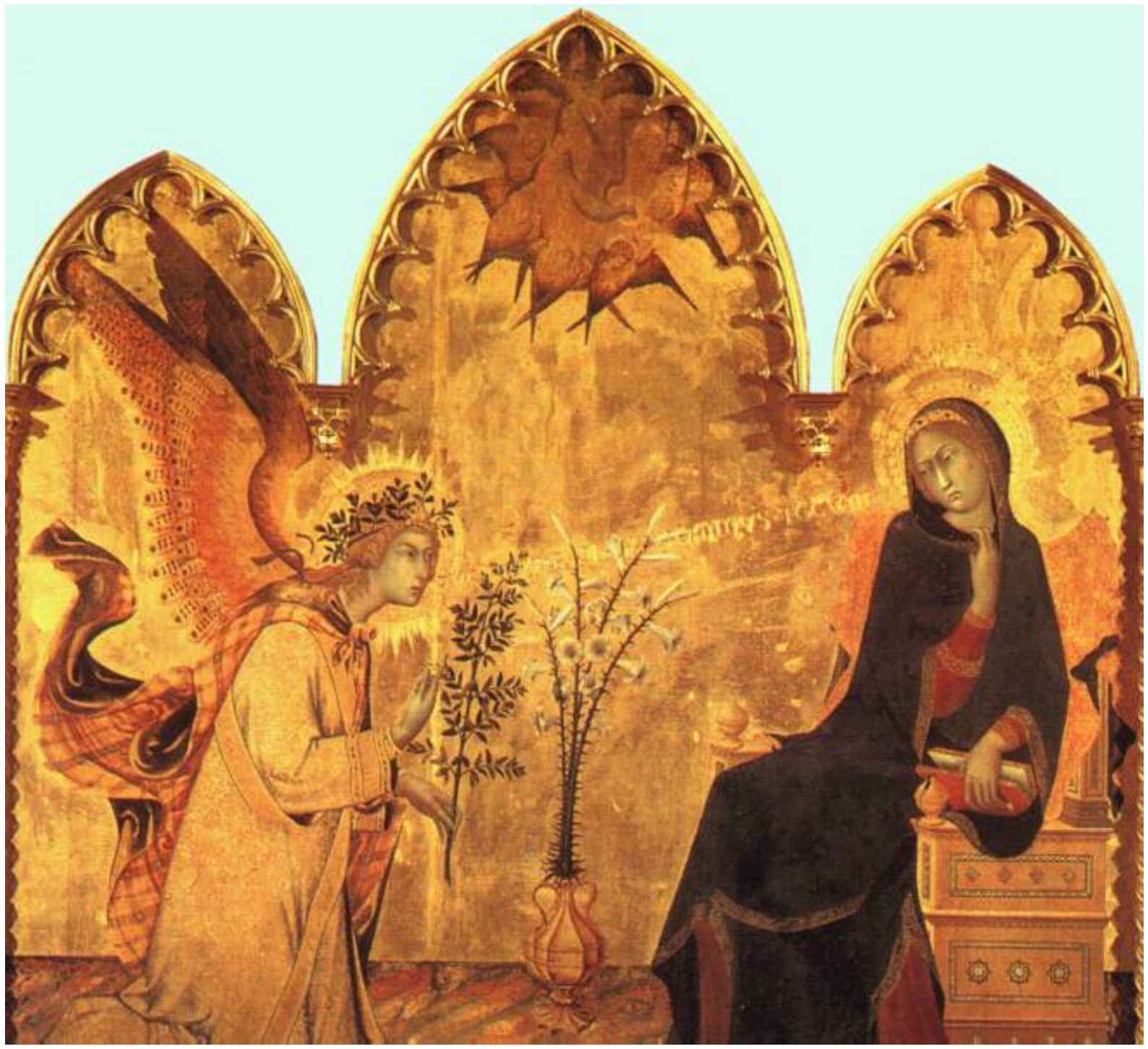

39. Simone Martini e Lippo Memmi: A Anunciação. Florença, Uffizi Fonte: http://www.ibiblio.org/wm/paint/auth/martini/2saints.jpg

Esse distanciamento se dá de maneira gradual. Por exemplo, diferentemente dos pintores medievais, Simone Martini representa os objetos de maneira realista. N'A Anunciação, como podemos observar, o vaso é um vaso real em um chão de pedra, assim como o banco onde está sentada a Virgem é um banco de verdade. $O$ livro que ela segura não é apenas o símbolo de um livro, "mas um genuíno livro de orações, com luz incidindo sobre ele e com sombra entre as páginas, o que deve ter sido estudado pelo artista com base num livro de anotações em seu gabinete de trabalho" (Gombrich: 1985, p. 161). Não é possível afirmar que a pintura de Simone Martini foi realizada a partir de princípios matemáticos; no entanto, a atmosfera geral e os ideais do século XIV podem ser sentidos a partir dessa pintura. Portanto, a 
visão física aos poucos foi suplantando a "visão espiritual" como representação ideal. O olho do corpo material substituiu o "olho interior" da alma cristã como o “órgão” básico da visão artística. Com observa Werthein (2001, p. 80), a imagem passa a ser valorizada não por evocar uma ordem espiritual invisível, mas pela proximidade com que o artista simulara o mundo físico.

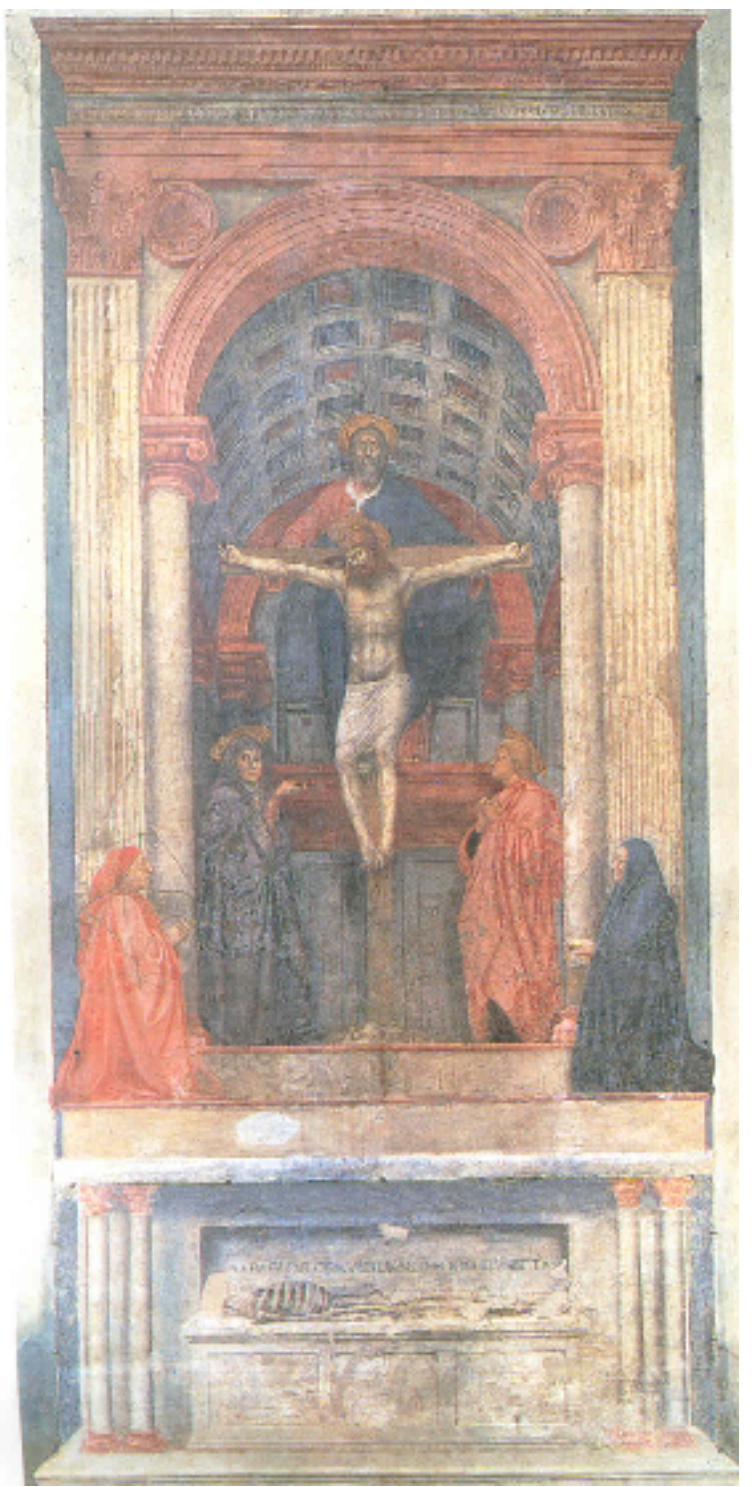

40. Masaccio: A Santíssima Trindade com a Virgem e São Jão sob a Cruz, e os doadores. Mural em Santa Maria Novella, Florença. Pintado por volta de 1427.

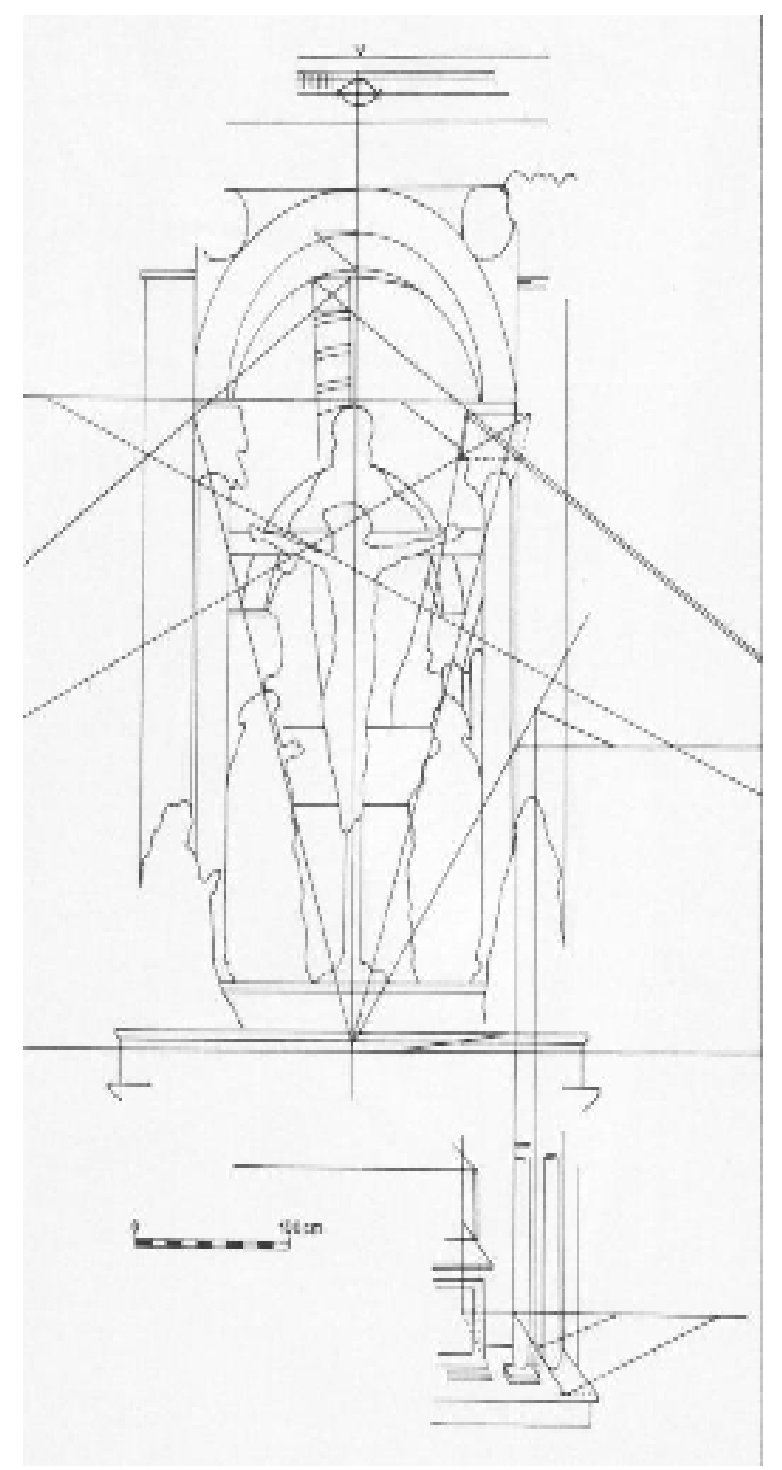

41. Esquema para a Santíssima Trindade (Web Gallery of Art)

Quem proporciona meios matemáticos para solucionar o problema do espaço, contudo, é Brunelleschi. Umas das primeiras pinturas a ser produzidas a partir de 
regras matemáticas foi um mural numa igreja florentina: a Santíssima Trindade com a Virgem e S. João sob a Cruz e os doadores - um velho mercador e sua esposa - ajoelhados do lado de fora, um mural executado por Masaccio (1401-28). Como podemos notar, o mural dá a impressão de que foi feito um buraco na parede, através do qual podiam ver uma nova capela no moderno estilo de Brunelleschi. Mas talvez ficassem ainda mais surpresos diante da simplicidade e grandiosidade das figuras que eram emolduradas. Como observa Gombrich, a sensação que isso causou entre os pintores deve ter sido imensa.

\subsection{O Renascimento}

As inovações instituídas por Brunelleschi em termos espaciais fizeram parte de um conjunto de investigações cujas sementes haviam sido plantadas já no final do século XIII; devido a uma nova maneira de perceber o mundo, passou-se de uma concepção metafísica para uma concepção humanista. Ou seja, já no final do século XIV um conjunto de indivíduos vinha se esforçando para modificar e renovar o padrão dos estudos ministrados tradicionalmente nas universidades medievais. Eram centros dominados pela cultura da lgreja e voltados para as três carreiras tradicionais: direito, medicina e teologia. Estavam mais interessados, pois, em "transmitir aos seus alunos uma concepção estática, hierática e dogmática da sociedade, da natureza e das coisas sagradas, de forma a preservar a ordem feudal" (Sevcenko, 1988, p. 14).

Iniciou-se, pois, um movimento cujo objetivo maior era atualizar, dinamizar e revitalizar os estudos tradicionais, baseados no programa dos studia humanitatis, que incluíam poesia, filosofia, história, matemática e eloqüência, entre outras. Para os studia humanitatis era necessário o estudo e a aprendizagem das línguas clássicas (latim e grego), e mais tarde do árabe, hebraico e aramaico. "Assim sendo, deveriam ser conduzidos, centrados exclusivamente sobre os textos dos autores da Antigüidade clássica, com a completa exclusão dos manuais de textos medievais" (Sevcenko: 1988, p. 14).

A grande revolução acontece porque os humanistas passaram a considerar a cultura que havia surgido e se desenvolvido no seio do paganismo a mais perfeita e expressiva, antes do advento do Cristo. Não que os humanistas fossem ateus, 
apenas desejavam reinterpretar a mensagem do Evangelho à luz da experiência e dos valores da Antigüidade.

Valores esses que exaltavam os indivíduos, os feitos históricos, a vontade e a capacidade de ação do homem, sua liberdade de atuação e de participação na vida das cidades. A crença de que o homem é a fonte de energias criativas ilimitadas, possuindo uma disposição inata para a ação, a virtude e a glória. Por isso a especulação em torno do homem e de suas capacidades físicas e espirituais se tornou a preocupação fundamental desses pensadores, definindo uma atitude que se tornou conhecida como antropocentrismo (Sevcenko: 1988, p. 15).

Na realidade, conforme observa Panosfky, a herança da Antigüidade clássica não foi ignorada em momento algum. O fato é que alguns fios desta tradição, em determinados momentos, tornaram-se extremamente tênues, mas isso não significa, de maneira alguma, que tenham sido irrecuperavelmente perdidos (Panofsky: 181, p. 25). Portanto, ao nos referirmos ao humanismo, devemos levar em conta que se trata de um vasto e profundo movimento cultural, riquíssimo de motivos e correntes, que aprofunda suas raízes nos séculos XIII e XIV, floresce nos séculos XV e XVI, perdurando até os séculos XVII e XVIII (Sciacca: 1962, p. 2).

Quando ouvimos falar a palavra humanismo, quase sempre a associamos ao Renascimento e a todas as suas implicações literárias, filosóficas e artísticas; porém, é consenso entre os estudiosos que o conteúdo humanista, assim como sua noção, varia no curso da história de acordo com as concepções de cada geração. Durante toda a Idade Média existiram revivescências intelectuais muito importantes que partilharam das mesmas características do movimento mais conhecido do século XV (Panofsky: 181, p. 25). Em cada período, portanto, o sentido assume uma significação diferente, distinta, muitas vezes ampliada. Por exemplo:

Nove dias antes de sua morte, Emmanuel Kant recebeu a visita de seu médico. Velho, doente e quase cego, levantou-se da cadeira e ficou em pé, tremendo de fraqueza e murmurando palavras ininteligíveis. Finalmente, seu fiel acompanhante compreendeu que ele não se sentaria antes que sua visita o fizesse. Este assim o fez e só então Kant deixou-se levar para sua cadeira e, depois de recobrar um pouco as forças, disse: "Das Gefühl für Humanität, hat mich noch nicht verlasse" - "O senso de humanidade ainda não me deixou". Os dois homens comoveram-se até às lágrimas. Pois, embora a palavra Humanität apresentasse, no século XVIII, um significado quase igual a polidez ou civilidade, tinha, para Kant, uma significação muito mais profunda, que as circunstâncias do momento serviram para enfatizar: trágica e orgulhosa consciência no homem de princípios por ele mesmo aprovados e auto-impostos, contrastando com sua total sujeição à doença, à decadência e a tudo o que implica o termo "mortalidade" (Panofsky: 1979, p. 19). 
Como bem observou Panofsky, Humanität tinha para Kant uma significação profunda, que ia de encontro à condição mortal do ser humano. Historicamente, segundo Panofsky, a palavra humanitas já carrega, desde sua origem, um aspecto duplo. Em um encontramos o contraste entre o homem e aquilo que é menos que ele; no outro, entre o homem e aquilo que é mais que ele. No primeiro humanitas significa um valor, e no segundo uma limitação.

Ainda no assunto relacionado à origem do conceito de humanitas, Panofsky diz o seguinte:

O conceito de humanitas como valor foi formulado dentro do círculo de que se rodeava Cipião, o Moço, sendo Cícero seu mais tardio, porém mais explícito defensor. Significava a qualidade que distingue o homem, não apenas dos animais, mas também, e tanto mais, daquele que pertence à espécie Homo sem merecer o nome de Homo humanus; do bárbaro ou do indivíduo vulgar que não tem pietas e паıঠદía - ou seja, respeito pelos valores morais e aquela graciosa mistura de erudição e urbanidade que só podemos circunscrever com a palavra, já muito desacreditada, "cultura". $\mathrm{Na}$ Idade Média este conceito foi substituído pela idéia de humanidade como algo oposto à divindade mais do que à animalidade ou barbarismo. As qualidades mais comumente associadas a ela eram, portanto, as da fragilidade e transitoriedade: humanitas fragilis, humanitas caduca (Panofsky: 1979, p. 20).

\subsubsection{Arte Matemática}

Como vimos, a importância do Renascimento em ciência, arte e política é o resultado de um movimento consciente, cujo aspecto intelectual foi obra de uma minoria de sábios e artistas que se opuseram ao modelo medieval e tentaram criar formas novas que se aproximassem dos modelos de Antigüidade clássica, grecoromana. Pela primeira vez as artes foram apreciadas em si, por si mesmas, e não como um meio para fins religiosos. Os artistas se interessaram por problemas novos, encontrando soluções materiais e intelectuais.

Entre a classe média florentina do Quattrocento, o discernimento matemático significava a culminação da formação secundária. Não obstante, tratava-se de uma matemática adaptada às necessidades comerciais e um dos problemas decorrentes deste uso específico da matemática é que os cálculos podiam alcançar proposições confusas, problema que certamente a matemática moderna não enfrentaria. No geral, davam extrema importância ao desenvolvimento intelectual; em razão disso, 
pintores e comerciantes acabavam tendo basicamente a mesma educação: uma geometria elementar. A geometria que conheciam era a mesma utilizada tanto por comerciantes como por alguns pintores; e, por sua vez, tornava a pintura um material de fácil reconhecimento. Essa formação em comum proporcionava fruições já previstas pelos pintores. Portanto, uma forma de suscitar determinadas associações era fazer uso intencional do mesmo repertório utilizado em exercícios típicos, ou seja, utilizando coisas familiares com as quais o observador havia aprendido sua geometria: cisternas, colunas, torres de ladrilhos, solos embalsamados etc. "Um pintor que deixasse traços de tal análise em sua pintura estava deixando pistas do que seu público estava equipado para reconhecer" (Baxandall: 1981, p. 116). Enfim, o artista emprestava às sensações organizações predominantemente intelectuais. Todavia Baxandall reconhece que, embora uma significativa parte dos comerciantes tivesse um bom senso de proporcionalidade, seria absurdo sustentar que todas as pessoas do comércio andavam buscando séries harmônicas nas pinturas. Na verdade, as pessoas não conheciam matemática mais do que nós, mas a utilizavam diariamente, portanto, com muito mais freqüência. Empregavam-na para tratar de negócios importantes, em jogos de adivinhações, além do fato de que a cultura intelectual, em geral, era, relativamente falando, muito mais importante do que hoje. Em relação à experiência visual, havia uma disposição maior para abordar estruturas e formas complexas como corpos geométricos regulares e de intervalos suscetíveis de ser organizados em série (Baxandall, 1981, p. 129). Foram os florentinos do Quatroccento que deram à arte o valor de uma ciência, libertando a pintura da condição artesanal, condição que vinha desde a Idade Média. Enfim, se houve na história uma época em que a criação artística pôde considerar as pesquisas científicas, esta época seguramente ocorreu no século $X V$, em Florença.

\subsubsection{Representação Perspectiva}

Perspectiva deriva, na verdade, do verbo "perspicere", ver claramente, "que é o equivalente do termo grego omтıxn, óptica. Assim, pois, originariamente, perspectiva se refere ao estudo dos fenômenos da visão, ao funcionamento do olho na percepção visual” (Gualis: 1984, p. 205). Portanto, perspectiva nada tinha que ver 
com representações espaciais tendo por base o rigor da matemática. Ainda mais que, tomando como ponto de partida a observação de Poincaré (1988, p. 57), a terceira dimensão somente surge pelo esforço de acomodação e pela convergência dos olhos. A vista, segundo ele, permite que avaliemos distâncias e, conseqüentemente, percebamos uma terceira dimensão. Logo, o esforço de acomodação e a convergência dos olhos, que são essenciais à percepção nítida dos objetos, são sensações musculares bem diferentes das sensações visuais que nos fazem perceber duas dimensões. Ou seja, perceber objetos em três dimensões requer esforço físico, ao passo que perceber objetos em duas dimensões, não! "A terceira dimensão não nos aparecerá como exercendo o mesmo papel que as outras duas. O que pode ser chamado o espaço visual completo não é, portanto, um espaço isótropo" (Poincaré: 1988, p. 56) ${ }^{9}$.

A característica básica da perspectiva linear é dar a impressão de que, ao olhar para uma tela, estar-se-ia olhando por meio de uma janela, uma vez que a imagem passa a ser uma projeção matemática da cena tridimensional sobre uma superfície bidimensional. Com tal método, os pintores acreditavam ter encontrado uma maneira precisa de simular aquilo que o olho efetivamente via. A chave da questão pode ser resumida da seguinte maneira: uma imagem em perspectiva é construída a partir de um ponto de vista único — o chamado "centro de projeção".

Para Piero della Francesca, por exemplo, considerava a perspectiva como uma extensão da Ciência. De acordo dom Field, a prova de que legitimava a perspectiva como "ciência legítima" era a mesma para provar que trata-se de uma extensão intelectual legítima; ou seja, uma construção com responsabilidade intelectual. O olho, nessas circunstâncias, não se move de maneira alguma; ele espalha seus raios de modo que forme um cone visual cujo ângulo vertical é um ângulo reto. A perspectiva, portanto, lida com a geometria de um único ponto de vista. "Acreditava-se que os dois olhos combinavam suas informações antes da mente processa-la" (Field: 2005, p. 152). 


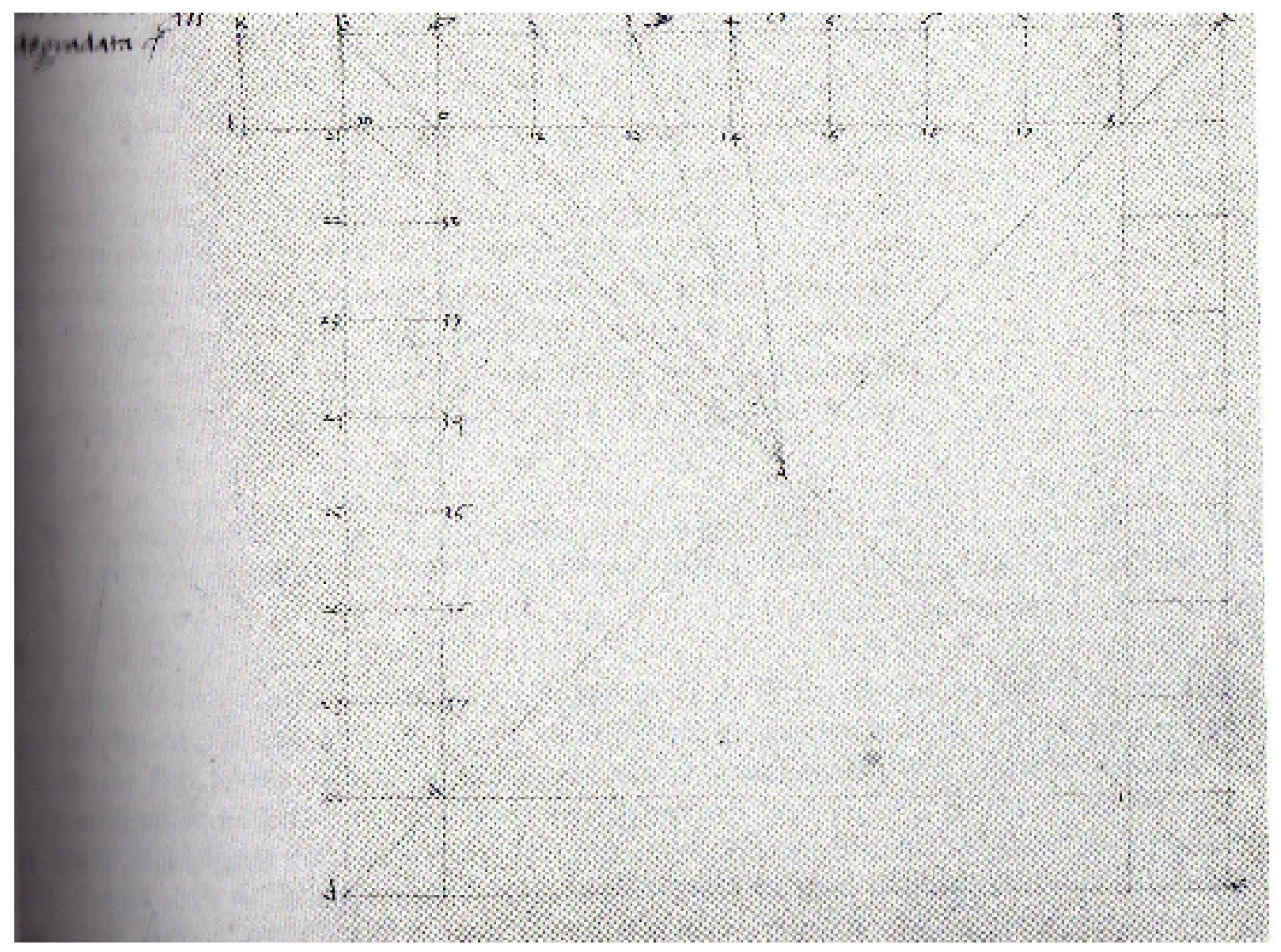

42. Piero della Francesca, De Prospectiva Pingendi, Livro 1; proposição 30, p. 17 in Piero della Francesca: A Mathematician's Art.

Os textos de Piero eram acompanhados de desenhos ilustrativos de suas proposições. Na figura acima, por exemplo, o ponto "A" indica o posicionamento do olho; como podemos perceber, encontra-se localizado no centro do quadrado. Segundo Field, a característica de Piero é introduzir provas a partir de instruções por meio de desenhos. O resultado final passa a ser verdadeiro na medida em que o for interpretado como uma representação exata em três dimensões. 


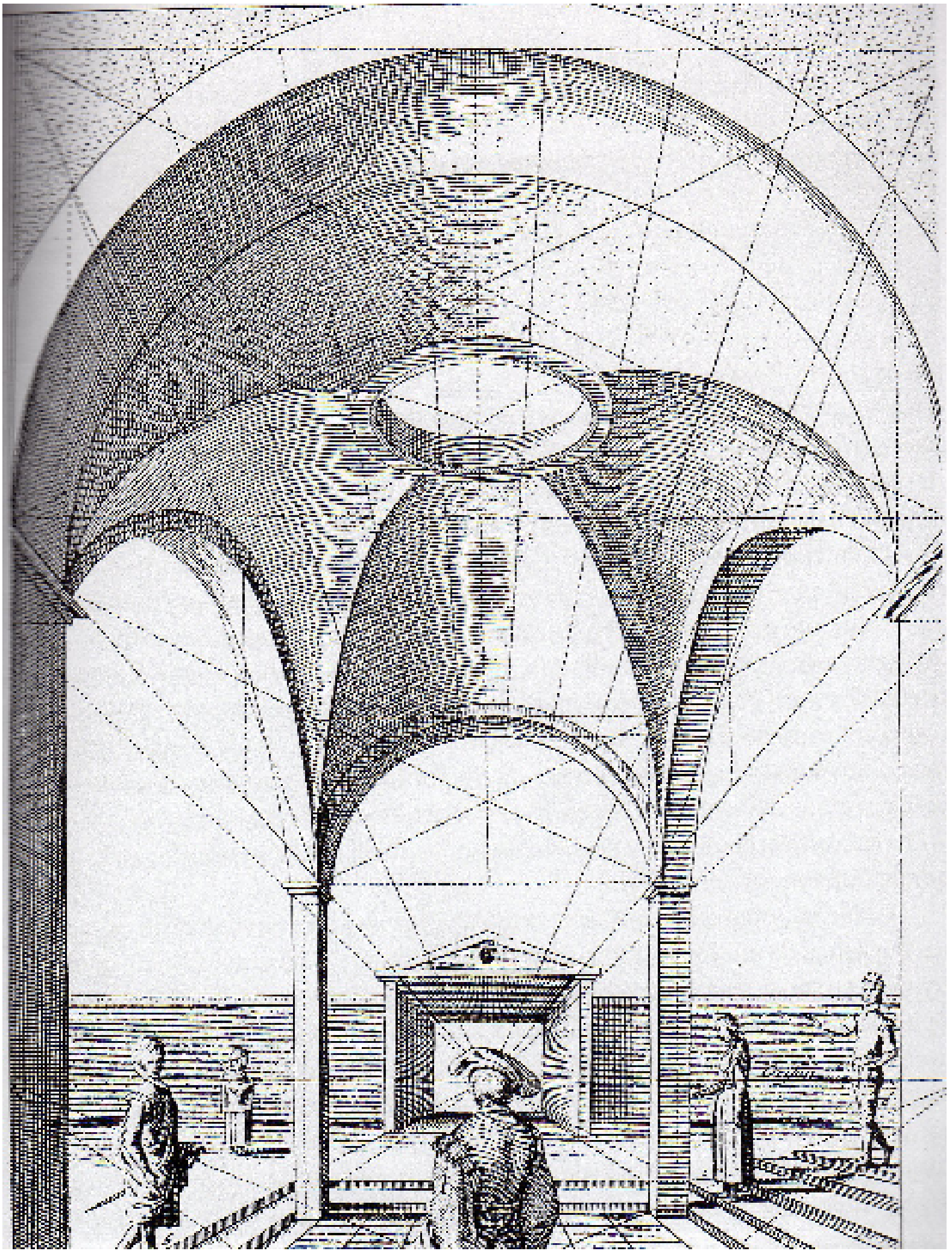

43. Jean V. de Vries, Perspective (lâmina 30). Wertheim: 2001, p. 83.

Uma obra emblemática para exemplificar a maneira correta de utilização da perspectiva é A Flagelação de Cristo de Piero della Francesca. Field (2005, p. 174) 
diz tratar-se não de um exemplo de perspectiva correta, mas de "o" exemplo de perspectiva correta. A parte da pintura que foi matematicamente organizado, pelo menos a parte mais visível, é a arquitetura.

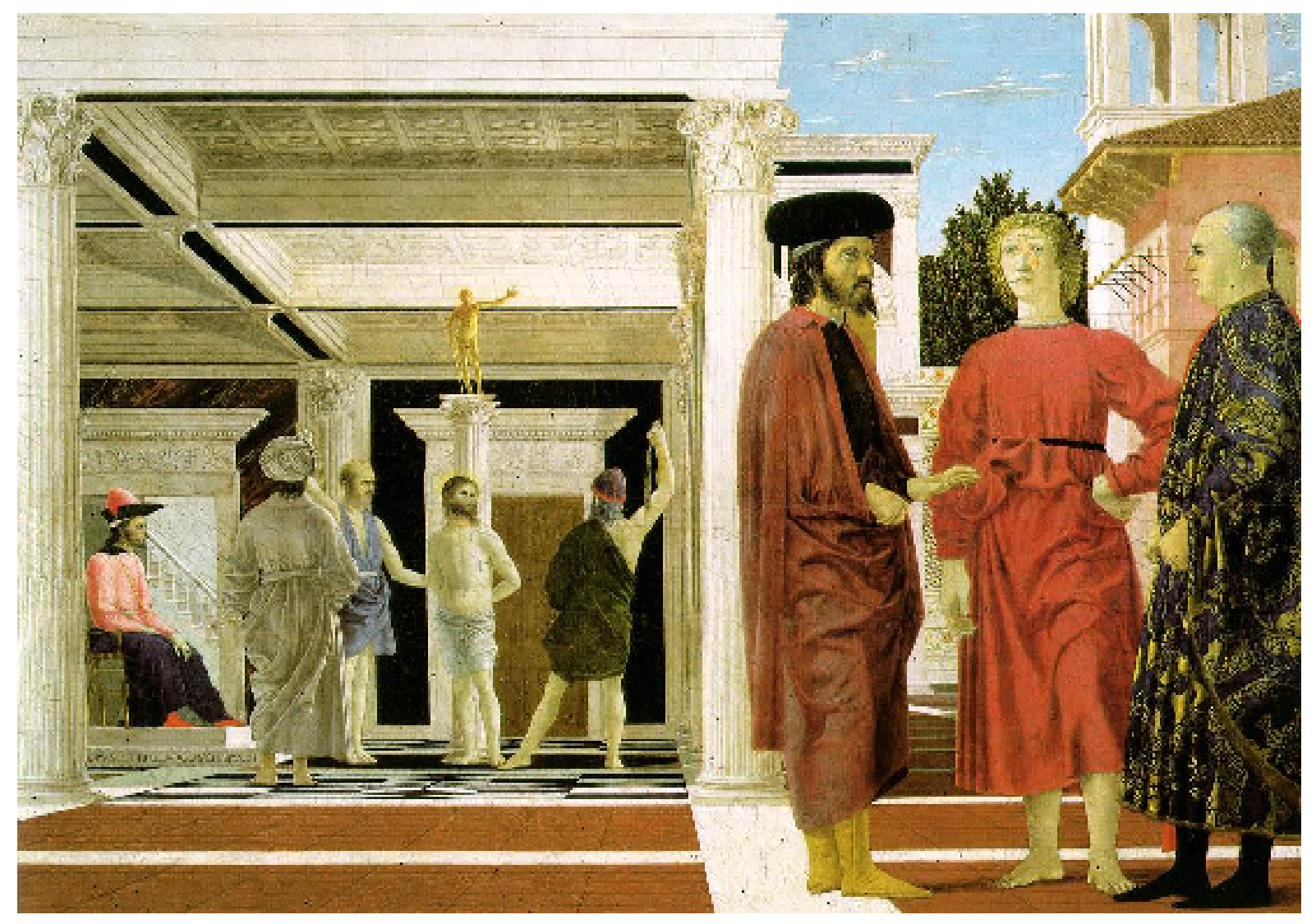

44. Piero della Francesca (c. 1412-1492). A Flagelação De Cristo. Galleria Nazionale delle Marche, Urbino Fonte: http://www.wga.hu/frames-e.html?/html/p/piero/francesc/index.html

Field observa que o fato de De prospectiva pigendi explicar, em tese, como utilizar a perspectiva de maneira correta, isso não garante que o leitor não tenha que estudar longas séries de instruções que acabam intimidando o interessado. Segundo Venturi (1954, p. 13), em um estudo biográfico e crítico sobre Piero, diz que à época de Piero, o conhecimento da realidade era o resultado não de uma revelação de Deus, como na Idade Média, mas de um estudo perspectivo da natureza. Sobretudo para Piero, a perspectiva era visto como um problema estritamente da pintura, e não como um problema científico (Focillon: 1991, p. 67). Embora muito importante para Piero della Francesca, a representação perspectiva não era um elemento primordial em sua pintura, pois ela não deveria absorver a imagem humana. "As cenas se 
desenrolam sempre diante do espaço criando pela perspectiva, e jamais dentro desse espaço, ou melhor, a perspectivase se insere na relação entre as personagens de uma multidão, dando assim o sentimento de profundidade à massa, mas ela não enforma jamais as figuras" Venturi: 1954, p. 15). Portanto ao mesmo tempo em que Piero demonstrava extrema habilidade na utilização da perspectiva, não ficava a mercê dela.

Fileld relata que nos afrescos de Piero há indicações de transferência de desenhos preliminares; e a uniformidade encontrada entre elementos repetidos, como cabeças, demonstra que havia padronização de alguns elementos. Com isso, o ponto de vista era determinado somente depois que a forma perfeita do objeto fosse completada.

Mas em muitas obras, como postula Wertheim, o ponto de fuga não é apenas o lugar a partir do qual a imagem foi construída, mas também o ponto a partir do qual a imagem deve supostamente ser vista. Numa imagem em perspectiva é possível, literalmente, tomar o lugar do artista, ou seja, seus olhos substituem o olho do artista a partir do ponto gerativo da cena. Tendo sido previamente estabelecido o ponto de vista, o observador terá diante si um lugar predeterminado para se postar. Em outras palavras, uma vez que o ponto de vista já estava codificado e determinado, espera-se que a imagem seja, também, recebida de um modo predeterminado.

Em certas obras isso é tão necessário que a porta de entrada a dadas significações só se realizaria efetivamente com o preciso posicionamento do observador em um ponto predefinido, porque é necessário colocar-se exatamente no mesmo ponto de vista do artista. Isso acontece com Fra Andrea Pozzo em Glória de Santo Inácio, pois somente assim tem-se a impressão de que a pintura se estende para além do teto da igreja. "Porém, se se contempla a pintura de qualquer outro ponto da igreja, as colunas parecem torcidas e o efeito de conjunto é ridículo" (Pedoe: 1982, p. 56). 


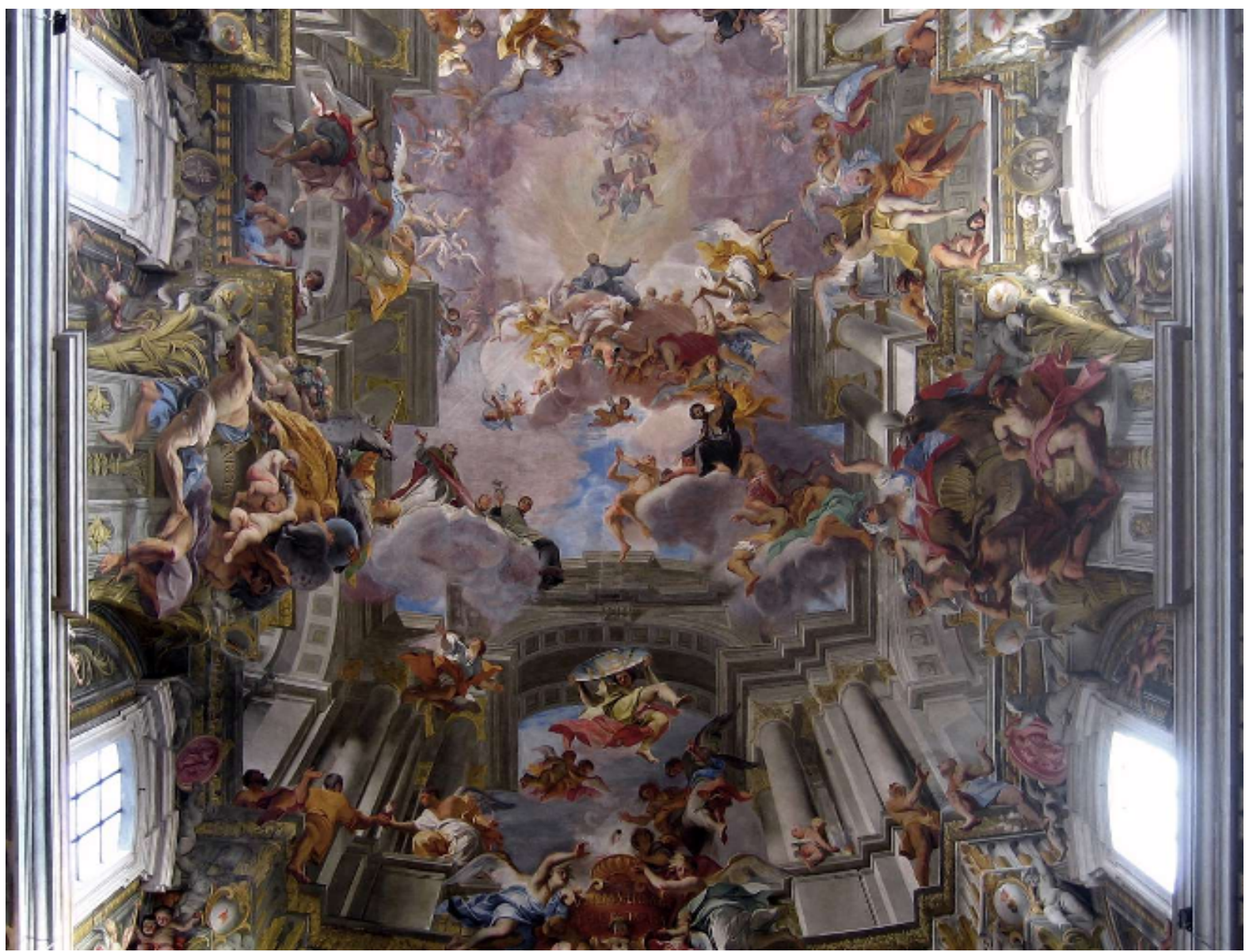

45. Fra Andréa Pozzo. Alegoria do Trabalho dos Missionários Jesuítas (detalhe) (1691-94). Fonte: http://www.wga.hu/frames-e.html?/html/p/pozzo/index.html

Outro fato curioso acontece, porém, ao olharmos uma imagem em perspectiva. Segundo Wertheim, de qualquer posição que não o centro de projeção, a mente se ajusta de modo tal que passamos a ter o mesmo ponto de vista do artista. "É como se a mente tivesse um "olho virtual" capaz de vagar pelo espaço independentemente do olho físico" (Wertheim: 2001, p. 87). Este olho virtual, que poderia vagar pelo espaço, forneceria às pessoas uma forte experiência psicológica de um espaço físico extenso como uma coisa em si, resultando dessa experiência, pois, diferentes significações. Wertheim postula que, em termos práticos, Giotto e seus descendentes artísticos ensinaram os europeus a olhar para o espaço de uma maneira nova. Ao optar por seguir este caminho, os artistas do Renascimento, sem o saber, lançaram as bases perceptivas e psicológicas para uma revolução na ciência. A autora ainda acrescenta que os pintores renascentistas, assim como os novos físicos, estavam empenhados em representar, de uma maneira matemática rigorosa, as relações físicas existentes entre os corpos materiais no espaço 
euclidiano. Para esses cientistas, o espaço euclidiano não era apenas o pano de fundo da realidade: supunham que sua própria neutralidade garantia que a ciência seria ela mesma neutra e objetiva.

Como postula Wertheim, a crescente obsessão com o espaço físico foi fatal para a velha imagem do mundo medieval, com seu esquema inerentemente espiritual. Se o "mundo real" consiste de corpos materiais que se movem num espaço euclidiano, onde fica Deus? Por fim, as esferas cheias de anjos, "a Grande Cadeia do Ser, a hierarquia do espírito, os esforços intencionais - tudo isso teria sido jogado fora, como mero lixo cultural, e em seu lugar estaria uma nova visão da totalidade cosmológica que, para o melhor ou pior, ainda hoje domina nossas vidas" (Wertheim: 2001, p. 89).

Ora, isso quer dizer que uma imagem em perspectiva precisa da presença de um indivíduo corpóreo, fisicamente localizado, ou seja, um corpo físico concreto em um espaço físico concreto. "Ao codificar a posição do corpo observante, a perspectiva vincula o espaço virtual da imagem e o espaço físico do espectador de uma maneira muito formal. A transição para a perspectiva marcou, portanto, uma transição não só na representação como também na recepção da imagem" (Wertheim: 2001, p. 82).

Com todas as implicações decorrentes desse método de representação, enfim, a Renascença se preocupou em representar características tridimensionais: a profundidade e o volume. O sistema pictórico da representação perspectiva deve tomar em consideração o ponto de vista "único e imóvel" que ignora a curvatura do campo visual, fazendo de conta que as formas se projetam sobre a nossa retina como superfície plana. É um sistema que se baseia sobre uma série de linhas que se encontram num ponto determinado sobre o plano: o tamanho dos objetos será diminuído proporcionalmente à distância calculada pelo encontro e interseção das linhas.

A perspectiva, por ser um modo de representação que recorre ao mesmo tempo à matemática e à ótica, foi amplamente aceita pelos pintores, que se voltavam não só para a natureza, mas também para a ciência. Como destaca Panofsky, "em todas estas fontes do século XV podemos ver que a função da pintura, até então limitada à imitação reprodutiva da realidade, se alarga à organização racional da forma - organização racional esta denominada por aquelas 
'justas proporções' cujo segredo teria sido revelado pela perdida 'doutrina dos antigos'” (Panofsky: 1981, p. 52).

$\mathrm{Na}$ verdade, a possibilidade de um ponto de vista único é totalmente impossível, jamais será alcançada. Primeiro porque, como demonstrou Kant, o tempo é seqüencial, logo, nunca seremos capazes de retornar ao mesmo lugar porque cada lugar pertence a uma parcela de tempo diferente. Segundo porque, conforme as observações muito interessantes de Poincaré, a Terra se move em torno do Sol que, por sua vez, gira em relação à Via Láctea. Outro exemplo que utiliza está relacionado à expansão de todas as dimensões do Universo. Poincaré inicia sua exposição pedindo que imaginemos que em uma determinada noite todas as dimensões do universo se tornassem um milhão de vezes maiores para destacar que, com esse fenômeno, o que era metro passaria a quilômetro; o que era milímetro passaria a metro; e que sua cama e seu corpo cresceriam na mesma proporção (s/d, p. 94). O curioso é que, segundo Poincaré, nada disso seria percebido, mesmo que utilizássemos medidas precisas. Isso porque as medidas também variariam na mesma proporção que os objetos.

Na realidade a mudança só existe para aqueles que argumentam como se o espaço fosse absoluto. Se eu tivesse argumentado por um momento como eles fazem, seria apenas para deixar bem claro que sua visão implica contradição. Na verdade, seria melhor dizer que, como o espaço é relativo, nada pode acontecer, e é por essa razão que não notamos nada (Poincaré, s.d. p. 95).

Como as distâncias sofrem uma grande variação sem que percebamos, de acordo com Poincaré, portanto, ao dizermos que estaremos em um determinado lugar amanhã, isso não significa, de maneira alguma, que estaremos no mesmo ponto que estávamos no dia anterior; esse amanhã significa que estaremos à mesma distância que estivemos de um determinado objeto no dia anterior. Por fim, "devo dizer que amanhã e hoje minha distância do Partenon será igual ao mesmo número de vezes da extensão do meu corpo" (Poincaré: s/d, p. 95). 


\subsubsection{Um Artista Matemático no Quattrocento}

Muitos artistas se viam obrigados a utilizar a matemática não por uma questão de composição, mas porque tinham de calcular quantas figuras caberiam em um determinado espaço. Por exemplo, imaginemos que uma capela tivesse 15 braccia de largura, 35 braccia de altura e que as paredes medissem 15 braccia de altura. Quantas cenas da vida da Virgem e da vida de Cristo caberiam, já que cada figura humana deve medir $1 \frac{1}{2}$ de altura? Ocorria também que, às vezes, a capela era construída para acomodar os afrescos; logo, o raciocínio matemático seria outro. Se o desejo fosse pintar figuras de tantas braccia por tantas braccia ilustrando uma passagem da vida de Cristo, de que tamanho deveria ser a capela (Field: 2005, p. 14)? Percebemos, pois, que a matemática foi utilizada, inicialmente, não como um recurso para organizar os elementos que seriam retratados numa passagem, mas para determinar qual o espaço que cada cena ocuparia em um determinado espaço físico.

Com Piero della Francesca, entretanto, a utilização da matemática assumiu outras dimensões, pois ele foi um dos artistas que mais exploraram seus recursos. Seu interesse foi tanto que ele chegou a escrever um manual: De ábaco, que é também o nome de um instrumento destinado a efetuar operações algébricas elementares. O artista colocava em prática, para analisar as formas que pintava, os mesmos pressupostos técnicos que muitos anônimos utilizariam para calcular quantidades. O utensílio de todo italiano culto no comércio do Quattrocento era a regra de três. Della Francesca nos explica essa regra da seguinte maneira: "A regra de três diz que um deve multiplicar o que se quer saber pelo que lhe é diferente, e dividir o produto pela coisa restante. E a cifra que surge disto é da natureza daquele que é distinto do primeiro termo; e o divisor é sempre igual à coisa que se quer saber" (apud Baxandall: 1981, p. 122).

Após ter dividido o espaço de modo que cada cena ocupasse espaços proporcionais segundo a importância de cada uma delas, os artistas utilizavam a geometria, pois era a partir dela que eles conseguiam a sensação de profundidade em um espaço bidimensional, ou seja, em um espaço que possui apenas a largura e 
o comprimento; a terceira dimensão deveria ser criada. Mas alguns artistas se valeram de outras expressões matemáticas para organizar o espaço, além da perspectiva.

Por meio desta prática diária, os indivíduos se habituavam a reduzir as mais complexas classes de informação a uma fórmula de proporção geométrica: A está para $\mathrm{B}$, assim como $\mathrm{C}$ está para $\mathrm{D}$, por exemplo.

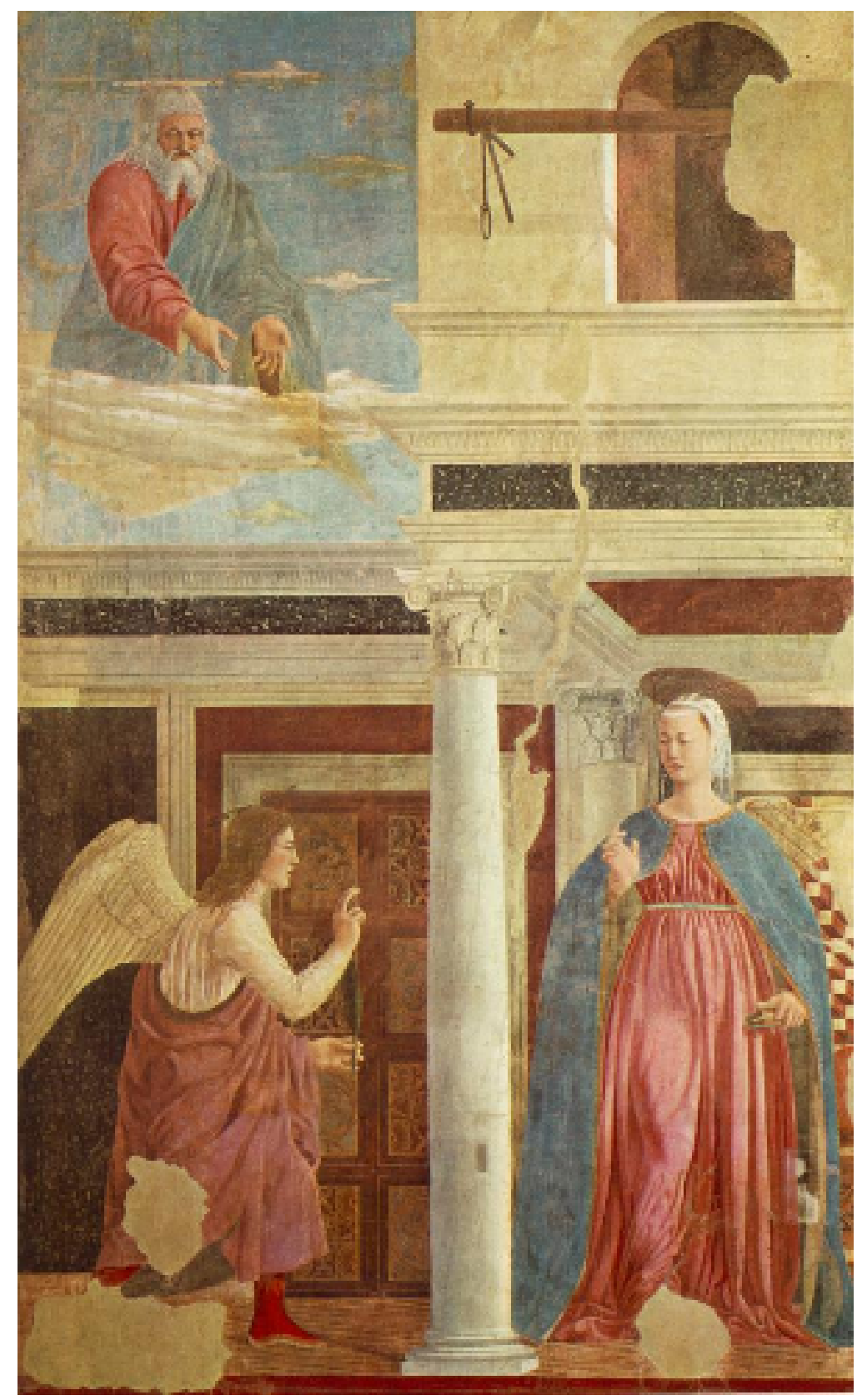

46. Ilustração 2: Piero della Francesca (c. 1412-1492). A Anunciação, A História da Verdadeira Cruz, 1452-66, São Francisco, Arezzo. http://www.wga.hu/frames-e.html?/html/p/piero/francesc/index.html 
N'A Anunciação (fig. 40), aparentemente, há essa relação. Deus está para o anjo - um ser divino por excelência e que, portanto, mantém uma ligação mais próxima com Ele -, assim como a parte superior à direita está para Maria. A parte de cima à direita é, na verdade, a incógnita, ou seja, aquilo que se quer saber. Então, vejamos: a regra de três manda que multipliquemos, em diagonal, aquilo que queremos saber pelo que Ihe é diferente; logo, simbolicamente, Deus multiplicou, de fato, Maria, pois lhe concedeu o dom da maternidade sem que, no entanto, perdesse a virgindade. E o anjo, por sua vez, é justamente quem faz o anúncio a Maria de que ela fora escolhida!

A utilização da regra de três para analisar alguns aspectos d'A Anunciação é apenas uma das inúmeras aplicações matemáticas que podem ser identificadas na obra de Piero della Francesca. Outro esquema que pode ser verificado é a disposição bem ordenada entre as partes e o todo - que, inclusive, outros pintores procuraram estabelecer entre os corpos e o espaço -, conseguida por meio da geometria.

\subsection{Piero della Francesca e a Geometria Euclidiana}

Como já foi dito acima, Piero della Francesca escreveu um manual sobre matemática. Há alguns exemplos que são efetivamente versões numéricas das proposições de Euclides. No De ábaco Piero apresenta uma série de problemas sobre quadrados, retângulos e outros polígonos. "Dois desses exemplos sobre pentágonos regulares envolvem a razão entre o lado e a primeira diagonal. Esta razão corresponde ao que Euclides chama de 'extrema e média proporção', que foi chamado de 'seção áurea' no século XIX. Pacioli chama essa razão de 'divina proporção"” (Field: 2005, p. 29). 


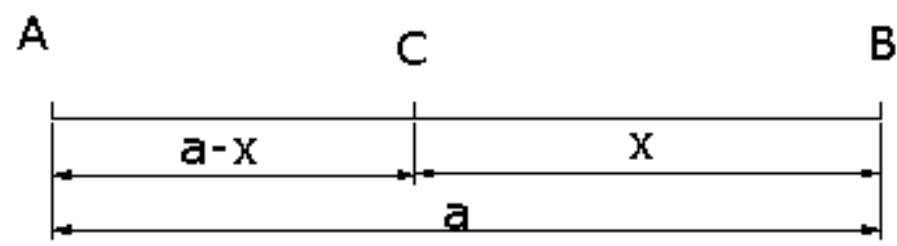

47.

Ainda de acordo com Field, foi só a partir dos estudos referentes a pentágonos inscritos em círculos que Piero Della Francesca deixou claro que alguns de seus problemas estavam baseados em proposições de Euclides.

Lavin, uma outra autora que destaca o conhecimento da geometria do século III a.C., na figura de Euclides, nos informa que Piero era tão familiar com a geometria Euclidiana que um autor chamado Carter sugeriu que no centro da estrutura geométrica de Batismo de Cristo está a proposição 16 do livro 4 de Os Elementos de Euclides, que demonstra como construir uma figura com quinze lados iguais. "De acordo com Euclides, primeiro um círculo e depois um pentágono eqüilátero em um triângulo. Piero pode ter pretendido utilizar o pentágono para se referir às cinco chagas de Cristo, um simbolismo apropriado ao significado do Batismo como o início da Paixão" (Lavin: 2002, p. 90). 


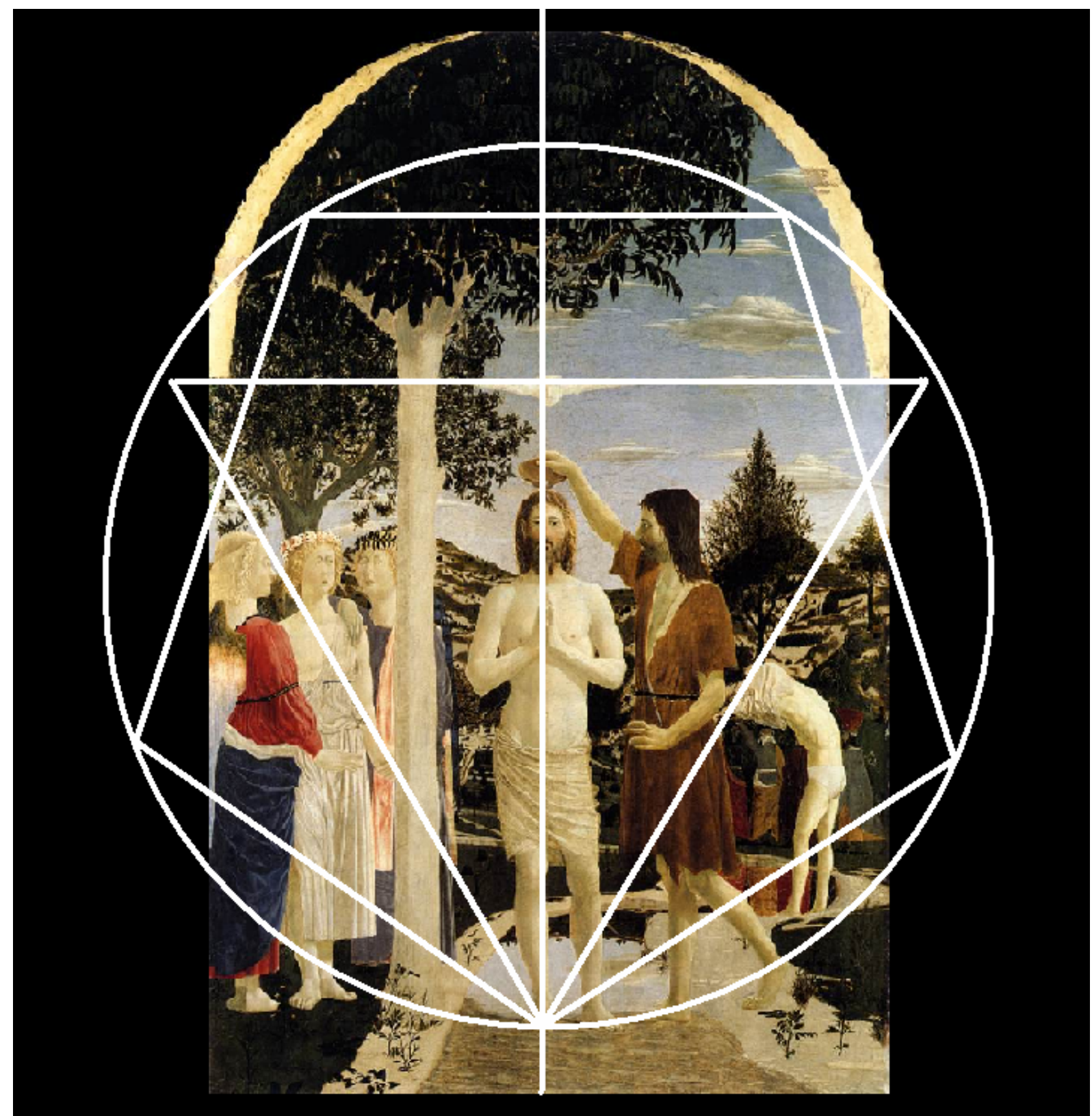

48. Piero della Francesca. Batismo de Cristo (c. 1460). Pinacoteca Comunale, Sansepolcro. Lavin: 2002, p. 92.

Retomando uma idéia desenvolvida na parte que tratamos das catedrais, mais precisamente quando falamos da utilização da geometria Euclidiana nas catedrais, podemos facilmente entender porque Os Elementos é um dos textos mais influentes de todos os tempos. Os Elementos propuseram uma série de problemas concernentes a construções de polígonos regulares inscritos em sólidos geométricos. Então, por exemplo, inscrever um octaedro em um cubo, para Piero, relacionava-se a propriedades simétricas dos corpos. Como observa Field, a origem dos trabalhos dos sólidos é mesmo Os Elementos, de Euclides. 
As figuras abaixo servem como exemplo para demonstrar tais preocupações.

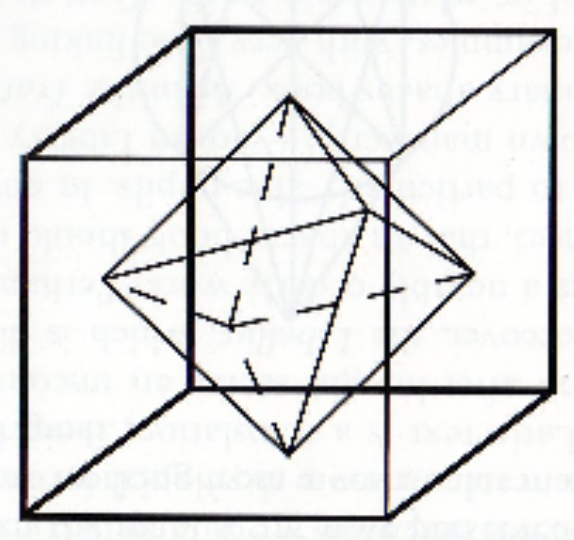

49.

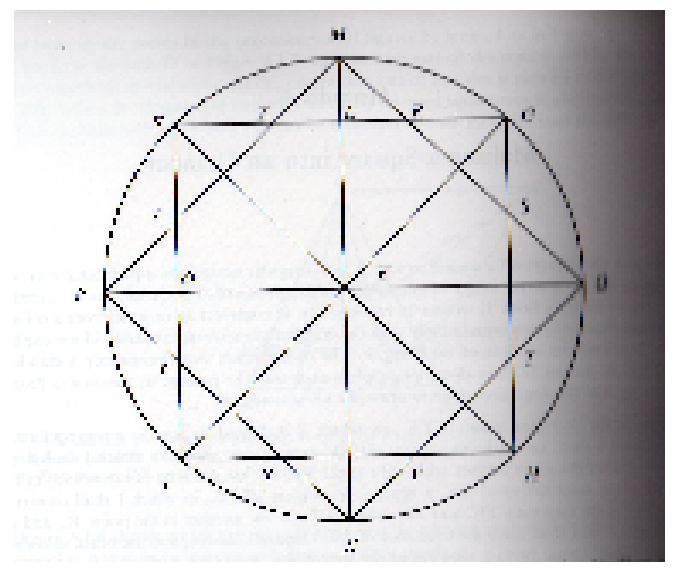

50.

\subsubsection{Um Artista Matemático do Cinqüecento}

Assim como Piero della Francesca no século $\mathrm{XV}$, a personalidade que mais simboliza a figura do artista matemático, por excelência, no século XVI é Leonardo da Vinci. Não obstante Da Vinci seja freqüentemente considerado um matemático, "sua mente inquieta não se fixou na aritmética ou na álgebra ou na geometria por tempo suficiente para que fizesse alguma contribuição importante" (Boyer: 1996, p. 191). Mas, como um típico exemplo de artista-cientista, Da Vinci precedeu os cientistas de seu período por observar a natureza, fazendo perguntas certas, e não por apenas recorrer a especulações e à introspecção (Atalay: 2007, p. 152). O elemento matemático mais utilizado por Leonardo da Vinci, além da perspectiva, foi o retângulo áureo.

\subsection{O Número de Ouro e o Retângulo Áureo}

Na Natureza, levando-se em consideração as proposições de Pitágoras, é possível encontrarmos muitos fenômenos naturais que confirmam a existência de regras matemáticas governando determinados processos físicos. Basta observarmos o Número de Ouro, assim como a Seqüência de Fibonacci, para nos darmos conta disso. 
A descoberta do Número de Ouro data aproximadamente de 2000 a.C. e sua aplicação ficou conhecida como Razão Áurea, ou seja, é a razão que existe entre a largura e o comprimento de um retângulo de ouro. Denomina-se Retângulo de Ouro um dado retângulo cuja divisão é feita de maneira tal que uma dessas partes é um quadrado, e o que resta terá de ser um retângulo com as mesmas proporções do retângulo inicial. A divisão assim feita é chamada de média e extrema razão; em outras palavras, isto quer dizer que é possível encontrar um determinado ponto cuja divisão é uma razão entre os dois segmentos: o número $\Phi(1,6180339887 . .$.$) , que$ nunca termina e nunca se repete. Esses números têm intrigado os homens desde a Antigüidade.

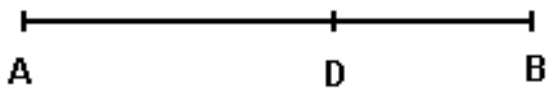

45.

Outra maneira de conseguir um Retângulo Áureo é a partir da construção de um quadrado:

\begin{tabular}{|l|l||}
\hline Construa um quadrado de lado unitário \\
Divida um dos lados do quadrado ao meio
\end{tabular}




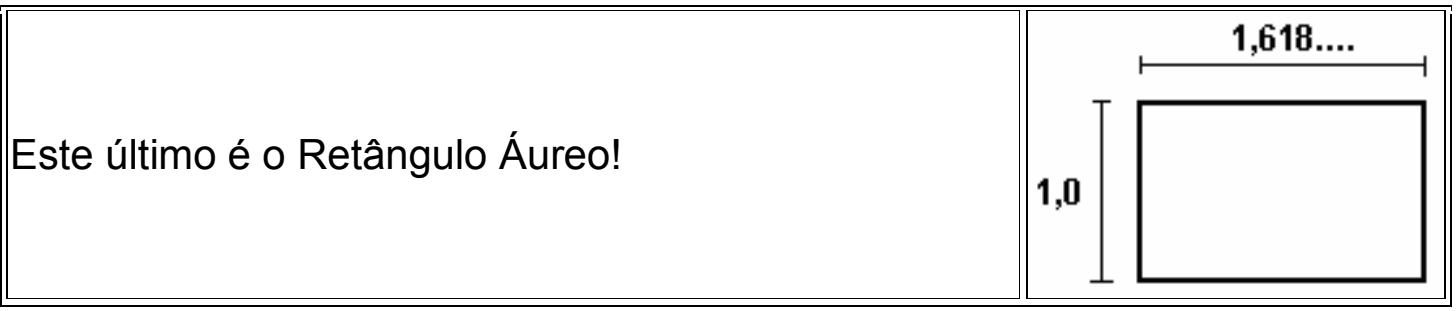

51.

Podemos perceber que Leonardo da Vinci incorporou a estrutura do Retângulo Áureo, sobretudo nos retratos. Segundo observações de Atalay, um retângulo áureo foi superposto a cada uma das figuras da seguinte maneira: desde o topo da cabeça até o limite do vestido. Acompanhemos, então, o raciocínio de Atalay:

Em seguida, traçou-se um quadrado na parte superior do retângulo, com a altura da cabeça determinando o tamanho do quadrado. As diagonais dos quadrados se cruzam no olho "composicionalmente dominante" das retratadas. A reta vertical que bisseca cada retrato passa através ou muito perto de um olho (...). Uma interpretação simples vê o rosto da Mona Lisa enquadrado por um retângulo áureo. Já a figura da retratada se organiza num retângulo áureo $\left(72^{\circ}-36^{\circ}-72^{\circ}\right)$ (Atalay: 2007, prancha 15).

A obra de Leonardo Da Vinci era impregnada de geometria e cálculos matemáticos. Assim como Piero della Francesca, Leonardo Da Vinci dedicou um tempo de sua vida registrando suas idéias sobre pintura: Trattato della pittura. Nesse caderno está registrado o modo como Leonardo via a pintura, ou seja, como uma ciência que permite a representação dos objetos visíveis. Para Leonardo aquele que desejasse se tornar um pintor deveria, primeiramente, dominar a matemática. Como observou Atalay, podemos seguramente afirmar que Leonardo sistematizou o uso do retângulo áureo em suas pinturas. Livio acredita que não há indicaç çoes suficientes que comprovem tal preocupação de Leonardo. "Na falta de qualquer indicação clara (e documentada) do lugar exato onde esse retângulo deveria ser desenhado, essa idéia representa apenas outra oportunidade para malabarismos numéricos" Livio: 2006, p. 187). Bem, os próprios rostos parecem conspirar contra tais observações de Livio! Não devemos nos esquecer em momento algum que se trata de uma obra de arte, portanto, o artista não precisa deixar marcar tão evidentes, ou mesmo "documentadas", para que cheguemos à conclusão de que de fato foi utilizado o retângulo áureo. 


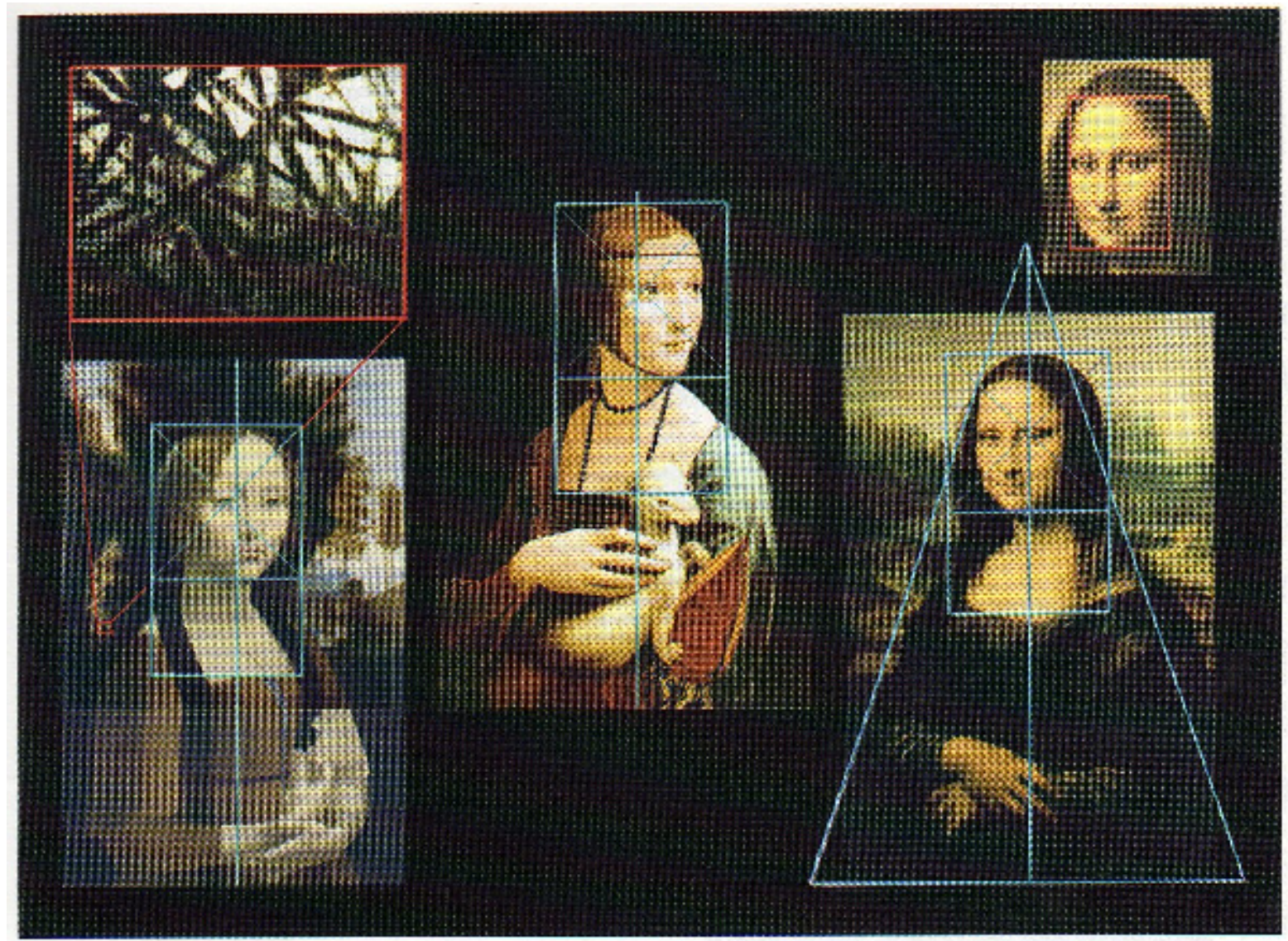

52. “Os três famosos retratos femininos de Leonardo. À esquerda: Ginevra de Benci.

\subsection{O sfumato e a Perspectiva Atmosférica}

Essas duas técnicas foram cruciais para o desenvolvimento do talento de Leonardo da Vinco. Dizemos isso porque, como destaca Gombrich, as obras dos grandes mestre do Quattrocento seguiram o caminho apontado por Masaccio, ou seja, as figuras parecem duras e quase de madeira - apesar da grande contribuição em termos espaciais, lembremos d'A Santíssima Trindade com a Virgem e São Jão sob a Cruz, e os doadores. Leonardo também conseguiu criar uma ilusão atmosférica de recessão espacial, sem utilizar aquilo que muito artistas do Renascimento amavam, a perspectiva com um ponto de fuga.

Logo, como vemos, não foi somente o retângulo áureo e a perspectiva que Leonardo utilizou com genialidade em suas obras para. A técnica que Leonardo utilizou para suavizar a passagem da parte iluminada para a parte mais escura e 0 sfumato. Em função dessa técnica "(...) nunca estamos muito certos quanto ao 
estado de espírito realmente refletido na expressão com que a Mona Lida nos olha" (Gombrich: 1985, p. 228). Daí o enigma que envolve o sorriso da Mona Lisa!

Da Vinci utilizou também um tipo de perspectiva que nada tinha a ver com a perspectiva que utilizava um único ponto de fuga. Leonardo percebeu que à medida que os objetos se afastam perdem os contornos; como o próprio nome já indica, trata-se de um fenômeno atmosférico, daí o nome de perspectiva atmosférica, ou linear. Portanto, de uma lado Leonardo evitou a tão amada perspectiva linear da maioria dos pintores da época em favor do que ele mesmo denominou de perspectiva linear - suavizar progressivamente os contornos e clarear as cores para criar uma ilusão de recessão espacial. Por outro lado, a técnica do sfumato uma invenção do próprio Leonardo que permitia a transição gradual da luz para a sombra, eliminando contornos acentuados e assim virtualmente dispensando as linhas. 

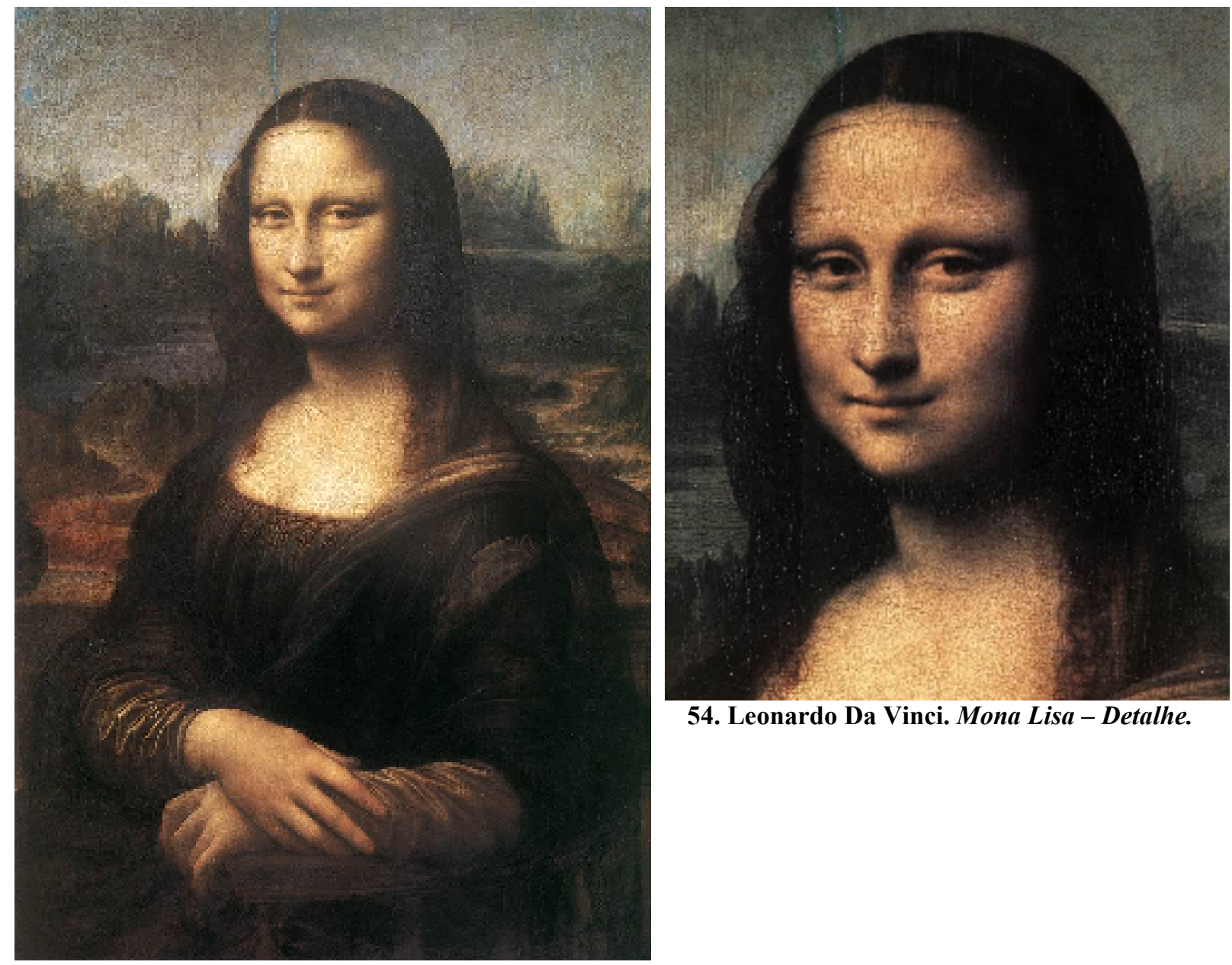

54. Leonardo Da Vinci. Mona Lisa - Detalhe.

53. Leonardo Da Vinci. Mona Lisa (c. 1502). Paris, Louvre

Vemos com isso que nem só de matemática vive o artista. A utilização da geometria, do retângulo áureo e da perspectiva foram instrumentos importantes nas mãos dos artistas, mas seguramente só isso não seria suficiente para que eles produzissem obras de arte.

Para finalizar, tanto Piero della Francesca como Leonardo da Vinci eram Euclidianos. Cada um utilizando os postulados de Euclides de maneira diferentes porque pertenciam a momentos históricos diferentes. Vejamos daqui para frente não mais a utilização de alguns dos postulados de Euclides para resolver questões que envolvem o efeito de profundidade em um plano bidimensional, mas as implicações ligadas á quadrimensionalidade. Ou seja, a preocupação agora é com um espaço de quatro dimensões. 


\section{III}

\section{A QUARTA DIMENSÃO E}

\section{A ARTE DO SÉCULO XX}

(Pablo Picasso, Marcel Duchamp e Salvador Dali)

\subsection{A Quadrimensionalidade Espacial ${ }^{10}$}

Ao estudarmos a quadrimensionalidade, é possível verificar que há uma quarta dimensão pré-Teoria da Relatividade Geral, que é espacial, e uma outra que é pós-Teoria da Relatividade Geral, e que é temporal. Mas a quarta dimensão, em seus primórdios, esteve ligada ao misticismo, a uma espécie de lógica que supostamente levaria os homens a importantes revelações. Para termos uma idéia, Wertheim dá o exemplo de um místico russo - Peter Demianovich Ouspensky que dizia que a verdadeira realidade é um êxtase quadrimensional imutável (2001, p. 143).

A partir do que essa experiência de êxtase imutável poderia ser vivenciada? Seria possível visualizar objetos que proporcionariam tais experiências? Tais objetos, de acordo com Hinton em 0 que é a quarta dimensão ${ }^{11}$, seriam margeados por quatro dimensões em vez de três, como nós! O raciocínio de Hinton é muito interessante. Segundo ele, ao traçarmos uma linha reta ela teria uma única dimensão (2); se construíssemos um quadrado, teríamos, assim, uma figura com duas dimensões $\left(2 \times 2=2^{2}\right)$; e, finalmente, se traçássemos um cubo, obteríamos uma figura tridimensional $\left(2 \times 2 \times 2=2^{3}\right)$. Teríamos, portanto, 2, $2^{2}$ e $2^{3}$ ! A seguir apresentam-se uma linha, 2 ; um quadrado, $2^{2}$; e um cubo, $2^{3}$.
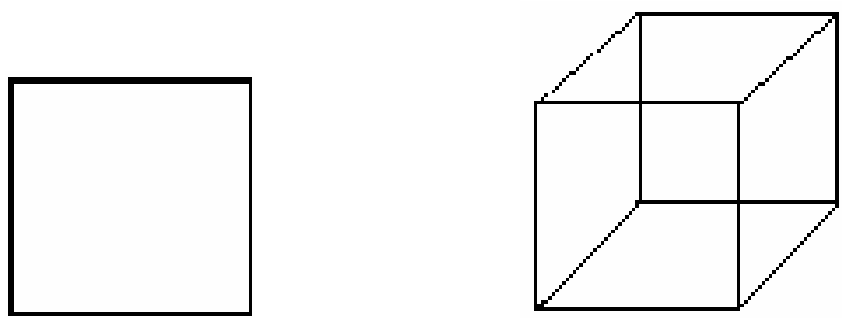

55. 
Logo, seguindo o mesmo raciocínio, a representação numérica de uma figura quadrimensional seria $2 \times 2 \times 2 \times 2=2^{4}$. A proposição teórica que responde a tal representação numérica é o hipercubo, ou seja, um poliedro com quatro dimensões. Para representarmos um hipercubo deve-se unir todos os vértices de dois cubos, conforme a figura seguinte.

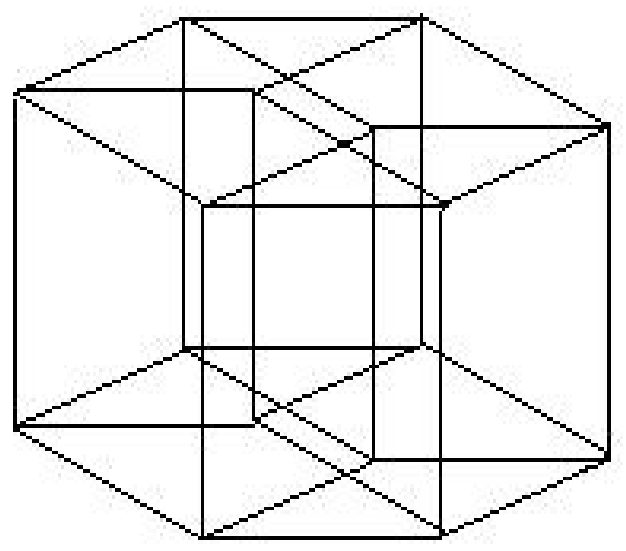

56.

O princípio da construção de figuras hipercúbicas - união dos vértices de dois cubos - é de fácil entendimento, porém de difícil visualização! Há outro exemplo cujo entendimento e visualização são facilmente compreendidos. É um modelo que inclusive Salvador Dali utilizou em Crucificação (Corpus Hypercubus), de 1954. Trata-se de um hipercubo formado por oito cubos colados pelas suas faces quadradas.

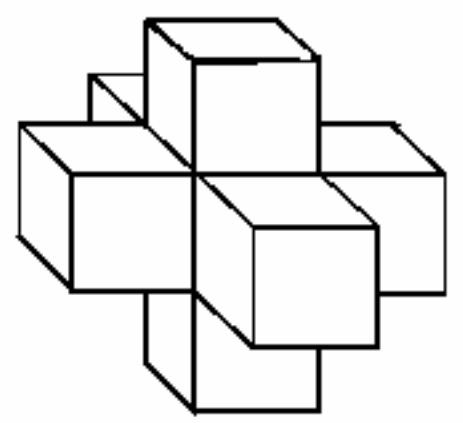

57. 
Hinton no adverte que (1980, p. 05), em vez de tentarmos encontrar objetos que correspondam exatamente à noção de quarta dimensão, é muito mais razoável entendermos as propriedades que tais figuras deveriam ter. Para tanto, devemos nos guiar exclusivamente pelo pensamento abstrato. Mas, segundo Poincaré, para se conseguir representar a quarta dimensão bastaria que fossem desenhadas várias perspectivas de um mesmo objeto, ou seja, desenhar um dado objeto de pontos de vista diferentes. E, segundo o matemático, isso não seria um problema, pois várias perspectivas têm sempre três dimensões. "Imaginemos que as diversas perspectivas de um mesmo objeto se sucedam; que a transição de uma para a outra seja acompanhada por sensações musculares" (Poincaré: 1988, p. 66).

No universo real existe um grupo de entidades que estão ligadas umas às outras segundo uma ordem quadrimensional bem definida e que são as bases do universo que nós percebemos e está longe daquele que a física nos permite explorar.

\subsubsection{Cubismo e a Quadrimensionalide Espacial}

O Cubismo é a terceira grande tendência da pintura contemporânea. Trata-se de uma escola artística derivada das preocupações de Cézanne de simplificar as formas, reduzindo-as a seus elementos geométricos básicos. Com essa redução a cilindros, cones e esferas, "Cézanne estava lançando, involuntariamente, a teoria da nova concepção de pintura, criada por Pablo Picasso (1881) e George Braque (1882-1958)" (Cavalcanti: 1963, p. 101). No cerne do movimento cubista está o desejo de transmitir a sensação total do objeto. Para tanto, os adeptos do movimento começaram a decompor as formas em diferentes planos geométricos e ângulos retos. Com essa atitude tentavam representar o objeto sob todos os seus aspectos: de face e de perfil, como se tivéssemos dado uma volta em torno do objeto. Como observa McLuhan, citando Gombrich, o cubismo substitui a ilusão da perspectiva pela apresentação de todas as facetas do objeto simultaneamente. "Em outras palavras, o cubismo, exibindo o dentro e o fora, o acima e o abaixo, a frente, as costas e tudo o mais, em duas dimensões, desfaz a ilusão da perspectiva em favor da apreensão sensória instantânea do todo” (McLuhan: s.d. p. 27). É em 
função dessa verdadeira revolução pictórica que Chipp (1968, p. 193) declara que durante os anos de 1907 a 1914 os meios pelos quais as imagens podiam ser formalizadas mudaram muito mais do que desde o Renascimento.

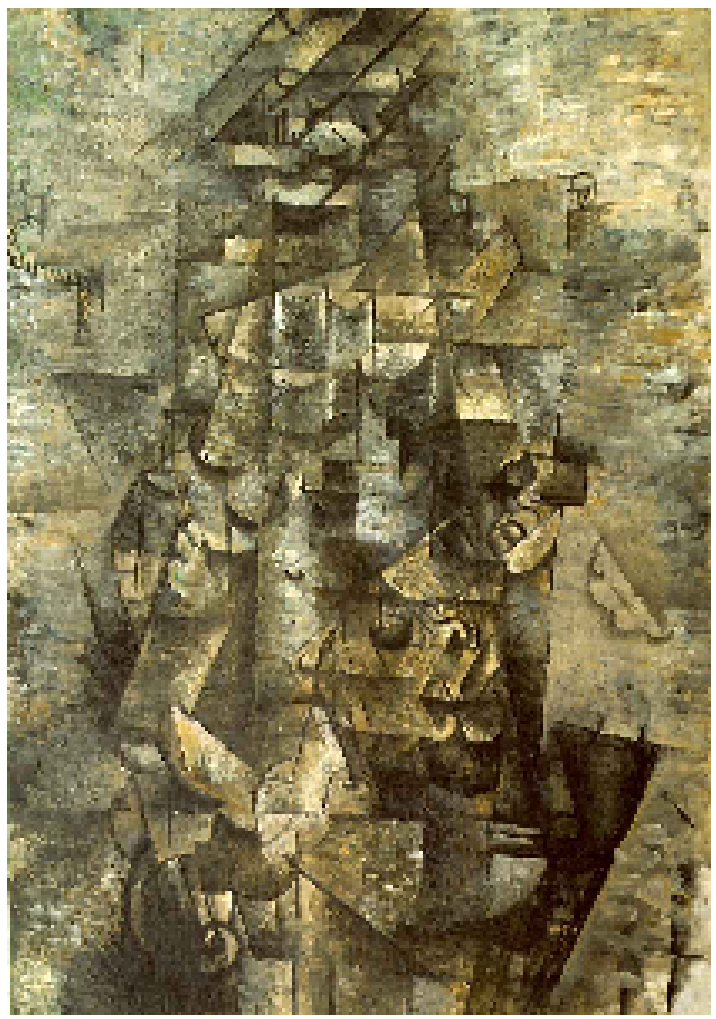

58. George Braque. Homem com uma Guitarra (1911).

http://www.artcyclopedia.com/history/cubism.html

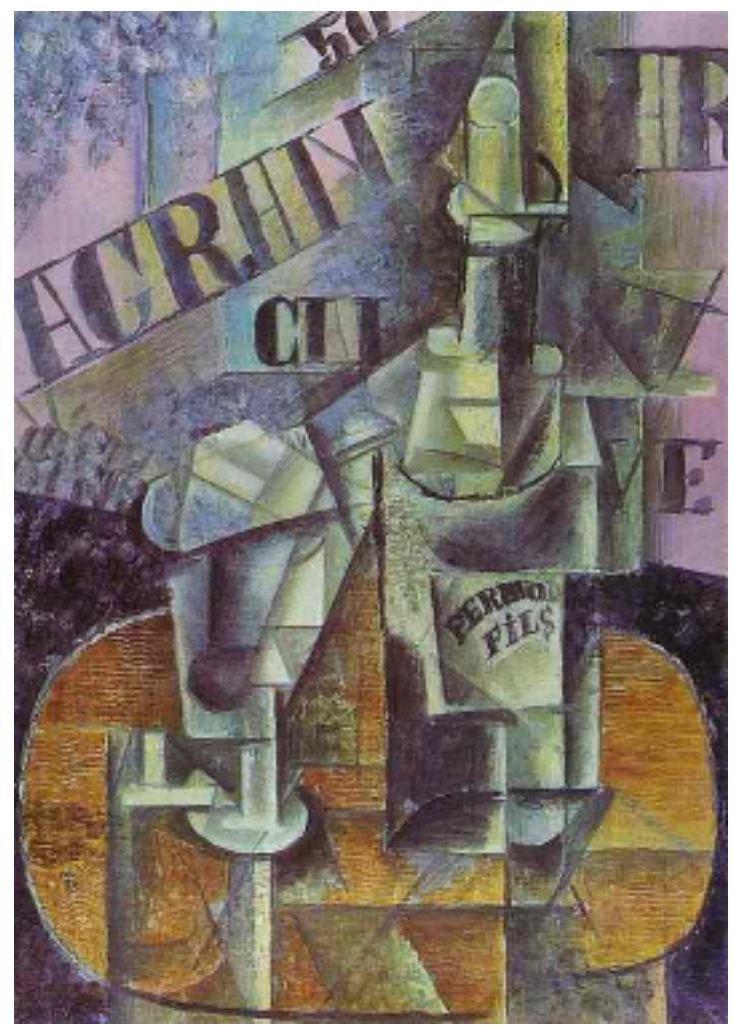

59. Pablo Picasso. Garrafa de Pernod (1912). http://www.artcyclopedia.com/history/cubism.html

A primeira fase do Cubismo é chamado de Cubismo Analítico por promover uma minuciosa decomposição, gerando, pois, uma verdadeira desintegração das formas. De acordo com o próprio Braque, fragmentar os objetos era um meio de ficar mais próximo deles, até os limites que a pintura permitisse. Como observa Bowness (1997, p. 114), Picasso e Braque levaram o Cubismo a um ponto em que somente os iniciados poderiam identificar o tema, de tão herméticos que eles tinham se tornado. A idéia do objeto passou a vir antes da tentativa de registrar sua aparência.

As preocupações dos artistas cubistas se fixaram muito mais na forma do que na cor, elemento expressivo de natureza intelectual. Logo, as cores, elementos essencialmente emocionais, foram deixadas em segundo plano. Devido a esse fator as composições de Braque e Picasso, nessa primeira fase, são geralmente em tons marrom. Na segunda fase do Cubismo, o Sintético, há uma volta às estruturas 
geométricas simples. Enquanto no Cubismo Analítico as formas são decompostas de maneira arbitrária em múltiplos elementos, no Cubismo Sintético ainda são mantidos os princípios gerais - a negação do realismo visual e dos processos ilusionistas de representação do espaço e do volume - , no entanto há a diminuição da decomposição das formas, que são feitas agora com maior síntese, restabelecendo, assim, as imagens visuais.

Os artistas cubistas também nutriam preocupações relacionadas à geometria, mas já não mais a geometria de três dimensões de Euclides. Como aponta Chipp, eles não pretendiam ser geômetras, como seus antecessores, pois passaram a se preocupar com novas possibilidades espaciais, ou seja, passaram a se ocupar da quarta dimensão. De acordo com Henderson (1998, p. 04), o crescimento da geometria $n$-dimensional e a quarta dimensão significaram uma dimensão espacial que ultrapassava os limites da percepção visual. Tais tópicos se tornaram elementos proeminentes na teoria cubista. Gleizes e Metzinger em Du Cubisme, por exemplo, afirmam que há uma relação entre a deformação das formas dos cubistas e o espaço não-Euclidiano. Do ponto de vista estritamente plástico, segundo Chipp, a quarta dimensão representa a imensidade do espaço que em um determinado momento se eterniza em todas as direções.

Henderson (1983, p. 44) observa que, diferentemente dos Estados Unidos, na França as idéias sobre a quarta dimensão ainda não haviam sido disseminadas; no entanto, esse quadro foi mudando à medida que artigos e livros de divulgação foram publicados em Paris no início do século XXe. Logo tais teorias teriam papéis importantes dentro da teoria cubista. Citando Apollinaire, Henderson destaca que a quarta dimensão dá ao objeto a proporção exata do todo. Em outras palavras, no novo espaço os elementos da paisagem, por exemplo, não mais assimilariam a proporção observada. É em função desse novo posicionamento que devemos entender a afirmação de Picasso: “(...) Eu pinto os objetos como eu os penso, e não como eu os vejo" (apud Henderson: 1983, p. 80).

$\mathrm{Na}$ realidade, os cubistas procuravam uma nova realidade que seria revelada por meio de uma sensitividade superior. Em função dessa sensitividade superior a liberdade passou a fazer parte do idealismo cubista, “(...) porque o ideal não era entendido como uma verdade absoluta, mas como uma realidade a ser descoberta por cada artista através de sua própria atividade criativa" (Henderson: 1983, p. 77). 


\subsubsection{Marcel Duchamp e Quadrimensinalidade Espacial}

Como nos informa Henderson, as informações sobre a geometria nãoEuclidiana e suas possíveis implicações estão se tornando disponíveis para os não iniciados muito lentamente. No entanto, à medida em que as informações começaram a circular com mais freqüência e se tornaram tema de discussão nos meios artísticos, a quarta dimensão e a geometria não-Euclidiana passou a ser tema de investigação para Marcel Duchamp. Logo, como a quarta dimensão havia se transformado em assunto comum a muito artistas, aparentemente Duchamp também fora fisgado por essa nova possibilidade, porém com uma diferença: ele sempre esteve interessado em formular suas próprias leis para a aplicação da quarta dimensão. As intervenções que Duchamp fez em relação à quarta dimensão tinham como base autores que abordaram tal questão como um elemento espacial. Duchamp acreditava que a geometria quadrimensional era necessariamente nãoEuclidiana. Segundo observa Henderson, “(...) embora novas definições de perpendicularidade e paralelismos sejam necessários, à medida que a quarta dimensão é acrescentada ao espaço, a geometria quadrimensional permanece basicamente Euclidiana e as linhas paralelas não se encontram" (Henderson: 1983, p. 147). Tais observações denotam, portanto, que a visão particularizada de Duchamp o distanciava daquilo que de fato era a quarta dimensão.

Segundo Henderson as intervenções de Duchamp começaram com o desejo de criar uma Noiva em quadrimensional. Na realidade ele especulou sobre a possibilidade de um ser tridimensional perceber a quarta dimensão. Duchamp logo percebeu que deveria examinar tanto as regras da perspectiva tridimensional quanto as leis da geometria quadrimensional.

Assim como os Cubistas, que tomaram como base a análise de Poincaré sobre o espaço perceptivo, Duchamp se volta para a exploração tátil como um meio par a o olho bidimensional perceber objetos quadrimensionais. De acordo com Henderson,

O olho bidimensional é incapaz de perceber a terceira dimensão de um objeto sem se mover ao seu redor, assim como um olho tridimensional não pode distinguir a quarta dimensão de um objeto a partir de um único ponto de vista numa perspectiva puramente visual. O olho tridimensional deve explorar, acumulando uma série de percepções do objeto 
quadrimensional, do modo como Poincaré sugeriu em seu método de representação (Henderson: 1983, p. 141).

De início Duchamp procurou representar a quarta dimensão de uma maneira exclusivamente tátil, em seguida abandonada. Opta, então, por uma ilusão visual da quarta dimensão baseada em espelhos e imagens virtuais (Henderson: 1983, p. 141). O princípio geométrico para se representar uma figura quadrimensional é, como já demonstramos na página 86 , unir todos os vértices de dois cubos. $E$ como já observamos, trata-se de um princípio matemático de fácil entendimento, mas de difícil visualização. É, aparentemente, seguindo esse mesmo princípio que Duchamp tenta criar a quadrimensionalidade. Com isso, a especulação de Duchamp sobre a intersecção de figuras geométricas são pessoais e falsas do ponto de vista geométrico. O mérito de Duchamp, de acordo com Henderson, é tentar estabelecer modos a partir dos quais a visão quadrimensional deveria operar (Henderson: 1998, p. 146). Para ele, no continuum da quarta dimensão o plano é sempre visto como uma linha. Não há mais o desenvolvimento perspectivo. A linha é vista como um ponto. Enfim, segundo Duchamp, um corpo tridimensional quando visto em um continuum quadrimensional é visto como um todo.

Faz sentido, então, a representação de um nu descendo as escadas feita por ele. Se fosse Slavador Dali, por exemplo, a representação de um nu descendo as escadas assumiria um caráter sexual, pois, segundo Freud, o ato de descer escadas repete a os movimento ininterruptos da relação sexual. Mas, como é facilmente percebido, Duchamp dá um caráter cinético à obra. Isso porque uma figura que desce as escadas individualiza as sucessivas posições, ligando-as num complexo ritmo de formas. Segundo $\operatorname{Argan}^{12}$, Duchamp determina uma mudança não apenas na conformação, mas também na estrutura do objeto: desmembra-o, altera o tipo morfológico de seus órgãos internos, muda o seu sistema de funcionamento biológico. A noiva é apresentada como uma série de colisões no reino da geometria, ou seja, o tridimensional em choque com a quarta-dimensão (Henderson: p. 179). 


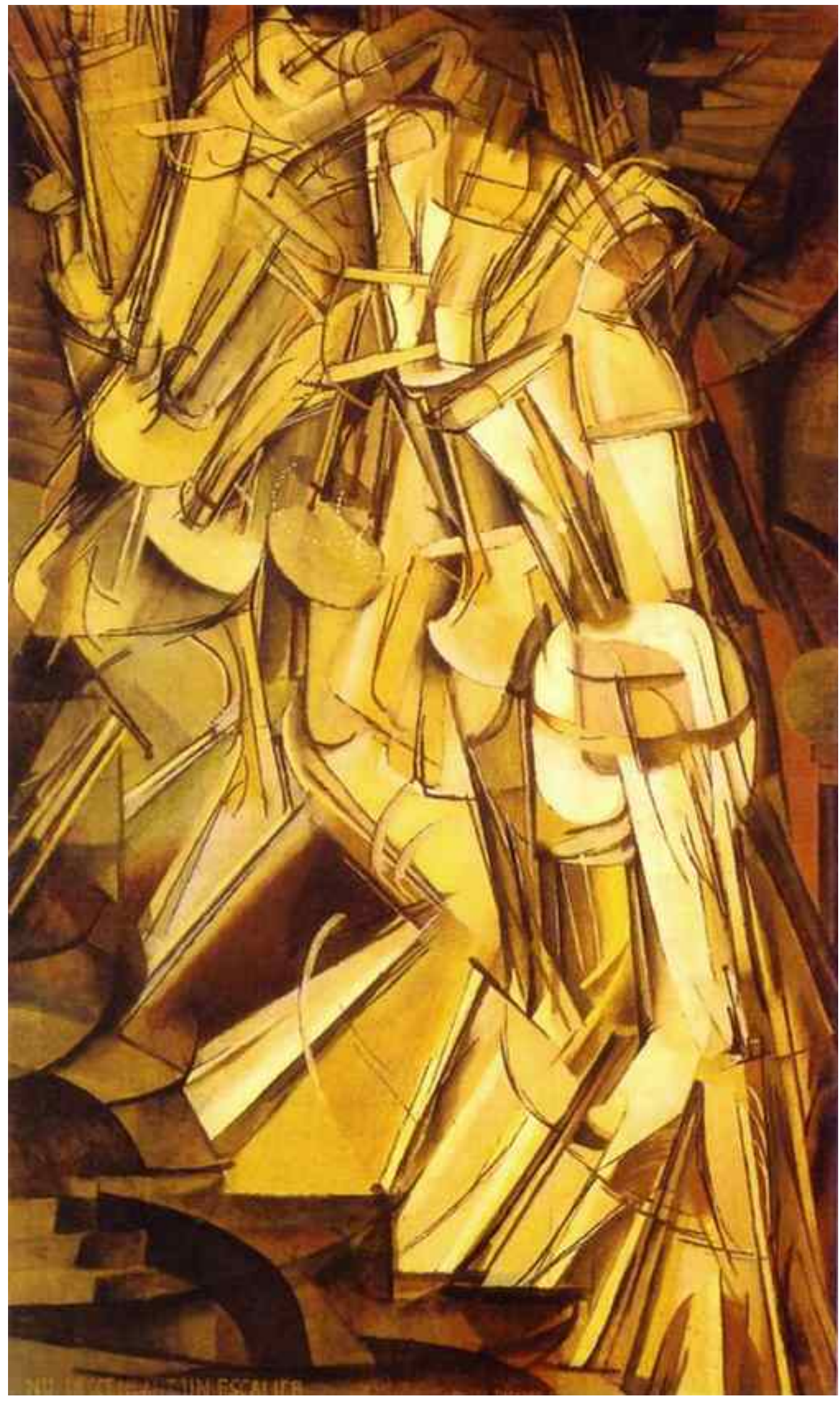

60. Marcel Duchamp. Nu Descendo a Escada (No.2). 1912. Oil on canvas 147.5 x 89 cm. The Philadelphia Museum of Art, Philadelphia, PA, USA. 
Segundo as observações de $\operatorname{Argan}^{13}$, o movimento de uma pessoa que desce a escada é um movimento repetitivo, mecânico, semelhante ao movimento de uma máquina. Ao executá-lo, a pessoa passa do estado de organismo vivo para o de engenho ou máquina; o funcionamento biológico se transforma em funcionamento mecânico. Com isso, o movimento, que é repetitivo, é também aquele a que, numa civilização da técnica, habitua-nos a familiaridade com as máquinas; portanto, a transformação do funcionamento biológico em funcionamento tecnológico é destino que nos aguarda. O que Duchamp busca incessantemente é a redução do movimento a uma linha, uma forma que se move no espaço. E à medida que a forma se desloca, a linha que é atravessada é substituída por uma outra linha depois outra e mais outra (Duchmap: 1994, p. 171). Agindo dessa maneira, segundo o próprio Duchamp, ele seria capaz de reduzir uma silhueta em movimento a uma linha do que a um esqueleto (p. 171). O Cubismo deu a Duchamp muitas idéias sobre a decomposição das formas (Duchamp: 1994, p. 173), porém o que ele realmente queria era discutir a quarta dimensão e a geometria não-euclidiana. Ora, enquanto o Cubismo Analítico é a análise do objeto estático, Duchamp é a análise do objeto em movimento.

Uma das preocupações de Duchamp, ao elaborar o Grande Espelho, foi discutir os problemas relacionados à perspectiva. Para ser mais preciso, ele tratou de um embate entre a perspectiva e a quarta dimensão. A perspectiva tratada por Duchamp não era realista, mas uma perspectiva científica, segundo suas próprias palavras (Henderson: 1998, p. 80). Já que tratava-se de uma perspectiva científica, o grande problema a resolver seria evocar a quarta dimensão na metade de cima de um Espelho. Segundo Duchamp, um objeto tridimensional é a projeção de alguma coisa quadrimensional. Por exemplo, para estabelecer uma perspectiva em quatro dimensões, Duchamp pensa em utilizar dois objetos semelhantes, porém de dimensões diferentes, um sendo a reprodução do outro.

Para Argan o pensamento de Duchamp é muito complexo, pois ele transformou as estruturas da teoria e da operação estética, chegando a negar que a arte seja o processo em que se realiza a atividade estética. Em a Noiva Despida por seus Celibatários, mais comummente chamado de O Grande Vidro, Duchamp, segundo Argan ${ }^{14}$, estuda o ciclo continuo de funções biológicas e tecnológicas, com 
amplas intervenções de simbologias inconscientes e alusões humorísticas, uma verdadeira contestação total da existência humana.

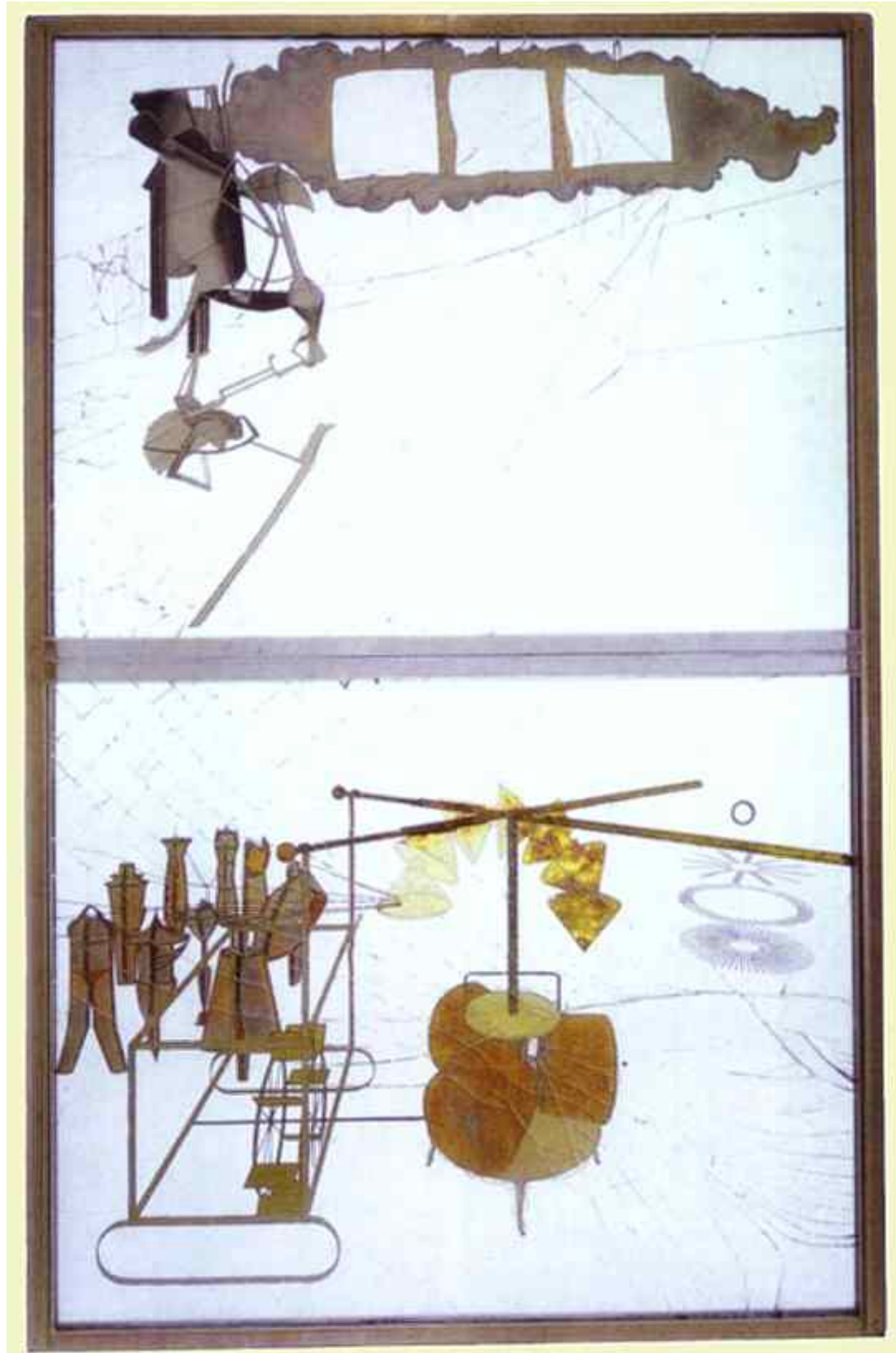

61. Marcel Ducahp. Noiva Despida por seus Celibatários. 1958. http://br.geocities.com/ideia_form/semana_22/duchamp.html

Noiva Despida por seus Celibatários é uma obra composta de duas lâminas de vidro, uma sobre a outra, sendo que na parte de cima pode se ver uma figura 
abstrata, que seria a noiva. Essa obra consumiu anos inteiros de dedicação de Duchamp, e só veio a público muito depois do início de sua construção, intercalada, portanto, por uma série de obras. Não se tem um consenso acerca do que representa essa obra, mas diversas opiniões conflitantes, com base em psicologismos e biografismos, renderam e ainda rendem bastante discussão. Segundo a própria definição de Duchamp, A é como se fosse a projeção de um objeto com quadrimensional.

A idéia básica dessa obra é produzir, por meio de dois objetos similares a quarta dimensão. A superfície bidimensional de um espelho poderia servir, segundo a concepção de Duchamp, de tradução prática da noção de uma infinitude tridimensional, "(...) o que o levou a idéia de que o continuum quadrimensional é essencialmente o espelho de um continuum tridimensional. (...) Essa mesma noção, de representar uma dimensão superior através e em termos de uma dimensão inferior, encontra-se na base das experiências ópticas às quais se dedicaria posteriormente, criando efeitos tridimensionais com objetos bidimensionais" (Schwarz: 1987, p. 14).

De acordo com Henderson, a ciência, a tecnologia e a geometria com quatro dimensões, que foram verdadeiras fontes de inspiração para Duchamp, foram suplantadas pelas novas descobertas, entre elas a Teoria da Relatividade e a Física Quântica. Interessante notarmos que Duchamp abandona a quarta dimensão em termos espaciais, substituindo-a por uma quarta dimensão temporal; ou seja, Duchamp deixa de lado a quarta dimensão geométrica e passa a se interessar pela quarta dimensão temporal no contexto da teoria da relatividade (Henderson; 1998, p. 222). 


\subsubsection{Salvador Dali e Quadrimensionalidade Espacial}

Antes de falarmos sobre a quarta dimensão na produção de Salvador Dali, acreditamos que seria oportuno entendermos o impacto dos estudos sobre a psicóse paranóica seu processo de criação, pois além da Interpretação dos Sonhos de Freud, Dali se interessou pelas descobertas feitas por Jaques Lacan em seu livro $D a$ Psicose Paranóica Em Suas Relações Com A Personalidade.

Dali tenta entender a psicóse paranóica por tratar-se de um "(...) desenvolvimento insidioso, sob a dependência de causas internas e segundo uma evolução contínua, de um sistema delirante duradouro e impossível de ser abalado, e que se instaura com uma conservação completa da clareza e da ordem no pensamento, na vontade e na ação" (Lacan: 1987, p. 11). Logo, por meio de um delírio - que por via de regra é sistematizado, elaborado intelectualmente, e que mantém coerência de unidade - uma visão particular do mundo é incorporada à personalidade intelectual do sujeito.

A psicose pode evoluir sem nenhuma degeneração mental ou orgânica. Nada é apresentado, de imediato, que determine a modificação do comportamento no início do distúrbio: o indivíduo é capaz de realizar atividades complexas sem que haja comprometimento de resultados; a capacidade intelectual permanece intacta. Como esses elementos não surgem de forma marcante, a gênese da doença é um distúrbio evolutivo da personalidade. Na psicose paranóica como desenvolvimento de uma personalidade não há indicação de nenhuma distinção, nenhuma anomalia gritante. As lembranças são remanejadas de modo sistemático, assim como as interpretações são desfiguradas, no entanto, mantém uma ordem no pensamento, na ação e na vontade.

Os delírios garantem autonomia em relação à personalidade; são delírios pessoais. $\mathrm{O}$ indivíduo já carrega consigo a gérmen que, futuramente, seguindo um sistema, determinará sua psicose. Citando Kraffl-Ebbinng, Lacan postula que "vemos, por exemplo, um indivíduo anteriormente desconfiado, fechado, amante da solidão, um dia se imaginar perseguido, um brutal, egoísta, dotado de opiniões falsas sobre seus direitos, vir a dar um querelante, um excêntrico religioso cair na paranóia mística" (apud Lacan: 1987, p. 47). Lacan ainda explica que a paranóia se diferencia das outras psicoses no grau de insistência. Há a permanência de disposições deficientes com relação à luta vital que explica a cronicidade do delírio, 
de onde surgem influências apaixonadas no combate às severidades externas. Isso ocorre por influição da falta de ferramentas que possibilitem o enfrentamento dos obstáculos impostos pela vida.

Sabe-se que o indivíduo não apresenta diferença de comportamento com relação a interpretações psicóticas. Não há nenhum instrumento que torne possível a diferenciação de uma interpretação cujos mecanismos sejam normais ou não. Os estados emocionais que afetam o indivíduo normal são os mesmos que atuam no indivíduo com propensões à psicose paranóica. Lacan sublinha essa passagem da seguinte maneira: “(...) eles invocam a influência favorável de estados bem diversos, dentre os quais a timidez, e todos os tipos de estados afetivos, fracos ou fortes, de ansiedade à paixão sem omitir a tensão atenta do surto" (Lacan: 1987, p. 57). Toda personalidade possui um estado que orienta o sujeito na relação com seu futuro. $\mathrm{Na}$ paranóia há um relacionamento com esse estado anterior que, dependendo de sua tendência, pode dar a característica principal do tipo de delírio (carcerário, de grandeza, perseguição etc.).

Este delírio, no entanto, não surge repentinamente: tem um processo de incubação bastante prolongado que estará ligado a tendências antigas do caráter, como destaca Lacan. Por intermédio do delírio a personalidade anterior vem à tona mantendo todas as suas inclinações. O delírio de interpretação é, portanto, um tipo específico que concerne a funções vitais, é inerente à organização fisica ou psíquica do indivíduo. Progride graças a uma irregularidade da personalidade, que se caracteriza por um desenvolvimento ou aumento excessivo (hipertrofia), ou pela sensibilidade desmedida a qualquer estímulo (hiperestesia) do eu, e pelo enfraquecimento da autocrítica. Isso tudo ocorre devido à não adaptação sofrida pelo indivíduo, como resultado de influências sociais. Como o sujeito não se integra ao meio, há, então, uma composição psíquica anormal que causa a predominância de "um complexo ideo-afetivo, assim como sua persistência e sua irradiação" (Lacan: 1987, p. 58).

Lacan ainda chama a atenção para o processo de sistematização do delírio, ou seja, para o dia em que a idéia delirante se torna sensação. Para exemplificarmos esse curso tomaremos algumas palavras extraídas por Lacan: o primeiro período do delírio crônico, período interpretativo, surge como uma manifestação de desordem mental provocada por unia brusca ruptura entre o passado e o presente, pelas modificações da atividade mental e pelos sentimentos 
de incompletude que daí resultam. O doente ao buscar uma explicação para esse estado de mal-estar forja interpretações insatisfatórias (Lacan: 1987, p. 59). Assim, o indivíduo, ao buscar explicações para seu estado de mal-estar, segue alguns pressupostos delirantes, admite como verdade algumas suposições em virtude do cruzamento com outras que foram aceitas anteriormente como verdadeiras. $O$ sujeito utiliza uma estrutura lógica num contexto estranho a essa aplicação, isto acontece devido a uma associação afetiva. "A afetividade é normalmente senhora de nossas associações. Mas, para fundar o juízo que dá sentido à associação de imagens, nós temos duas bases: resíduo empírico e valor afetivo" (Lacan: 1987, p. 61). Os resíduos empíricos são aqueles fragmentos que ficam gravados no espírito e que foram alcançados por meio de aspirações passadas e das respostas obtidas no mundo exterior. $\mathrm{O}$ valor afetivo se refere à a importância que um determinado sujeito dá ao que está contido em uma sensação ou em um pensamento. Isso tudo levando em consideração suas tendências, que não se modificam, ou os sentimentos atuais, que podem estar combinados a esse conteúdo de forma associativa ou de maneira implícita.

\subsubsection{Dali e a Atividade Paranóico-Crítica}

Dali, paralelamente à leitura da tese de Jacques Lacan, deu início a um novo método de análise: a Atividade Paranóico Crítica. Segundo a definição de Dali, tratase de um "método espontâneo de conhecimento irracional baseado na associação crítico- interpretativa dos fenômenos delirantes" (Dali: 1974, p 19). As imagens que Dali registrava em suas telas eram fruto de um método cujo significado não surgiu a partir da intuição lógica. Isso porque nela não há elementos suficientes para seguir os passos evolutivos dos delírios de associação interpretativa, uma vez que eles apresentam elementos ativos e sistemáticos que só dizem respeito a paranóia. A presença desses elementos não pressupõe a idéia do pensar dirigido voluntariamente, nem de um compromisso intelectual, porque na paranóia a estrutura ativa e sistemática é consubtancial ao fenômeno delirante em si. A influência do meio faz com que o indivíduo receba matéria e energia que são circundantes a ele e que, por sua vez, sofrem a influência dos delírios de caráter interpretativos; seguem intenções que já se encontravam no espírito do indivíduo. Tem-se portanto um sistema aberto, próprio da paranóia. 
Em Mercado Escravo com o Busto Invisível de Voltaire (fig. 50), Dali trabalha com imagens duplas. Gala, sentada, está olhando para um grupo de mulheres vestidas com roupas típicas da Espanha do século XVII. Elas, juntamente com as ruínas que estão atrás, formam, como o próprio nome do quadro já indica, o busto invisível de Voltaire.

O interessante desta tela é o fato de que, à primeira vista, enxergar simultaneamente as mulheres vestidas com roupas características do século XVII e o busto invisível de Voltaire não é um exercício simples. Dali consegue que decodifiquemos a imagem somente após um certo treino visual, pois as imagens se misturam. Esse quadro ilustra bem o que Dali queria dizer com conhecimento irracional baseado na associação crítica-interpretativa dos fenômenos delirantes. Enfim, tal imagem é fruto de uma interpretação paranóica, ou seja, o fenômeno da paranóia como uma idéia totalizadora e homogênea.

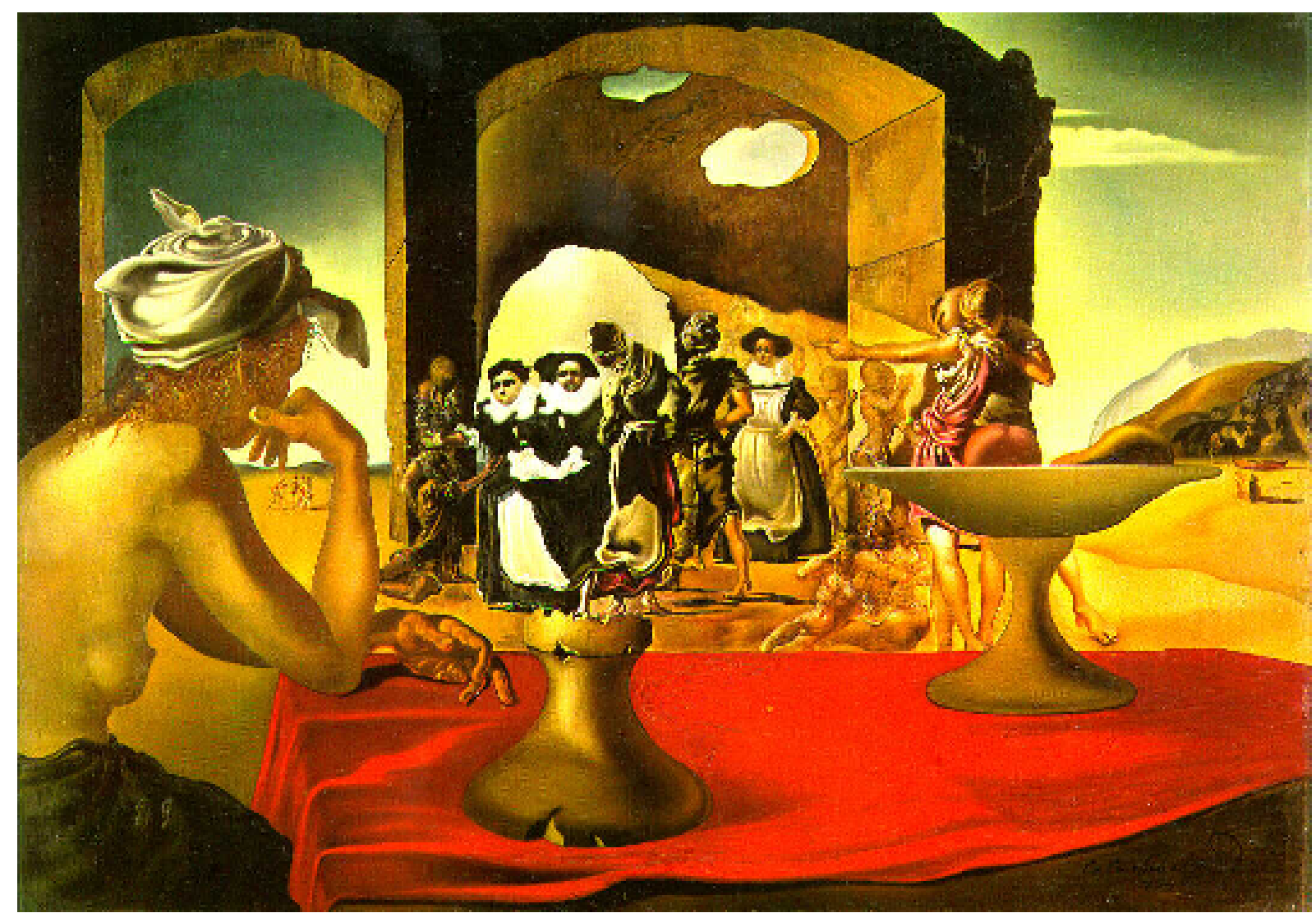

62. Salvador Dali. Mercado Escravo com o Busto Invisível de Voltaire, 1940. Disponível em http://www.daligallery.com/html/galleries/painting14.htm. 
O que percebemos é que Dali, a partir da teoria psicanalítica - freudiana, mas principalmete lacaniana - utiliza a quarta dimensão espacial para enfatizar seus fenômenos delirantes e místicos. Portanto, enquanto os cubistas, e de uma certa maneira Marcel Duchamp, exploraram a quarta dimensão em função do espaço, Dali acrescenta uma dimensão psicológica às questões plásticas. Ou seja, como já foi dito anteriormente, do ponto de vista estritamente plástico, a quarta dimensão para os cubistas representou a imensidade do espaço que em um determinado momento se eterniza em todas as direções.

Em Cristo de São João da Cruz Dali explora seu lado místico. A fé cega, segundo ele mesmo declarou, o atraiu para os ensinamentos de um mago, Ramón Lull. Para Dali “(...) toda nova investida no campo da cosmogonia ou metafísica terá de estar baseada na magia" (Gérard: 1987, p. 100). Ao contrário de Andrea Pozzo - que nos dá para olhar a imagem vista de baixo - , Dali apresenta-nos o Cristo crucificado visto de cima. O ponto de fuga, portanto, é terrestre; é como se um cone se abrisse em direção aos céus. Dali nos força dessa maneira a compartilhar de seu misticismo, uma vez que só a partir de um ponto de vista privilegiado teríamos tal visão.

Neste quadro específico, Dali ainda não enveredou pela quarta dimensão e nem pela geometria não-Euclidiana - embora Dali cite eventualmente cite a geometria não-Euclidiana, ele, na realidade não tenha se ocupado dessas descobertas. Podemos seguramente dizer que Dali ainda é Euclidiano e tridimensional. Mas o evento que mais impressionou Dali foi a explosão da bomba de Hiroshima, no final da guerra. A partir daí o átomo passa a ser seu alimento predileto para o pensamento, como ele mesmo diz. Vejamos o que ele diz a respeito:

\footnotetext{
Muitas das paisagens pintadas nesse período expressa o grande medo inspirado pelo anúncio daquela explosão. Eu apliquei meu método paranóico-crítico para explorar o mundo. Eu quero ver e entender as forças e as leis ocultas das coisas, obviamente para domina-las. Para penetrar no coração das coisas, eu sei por intuição genial que eu tenho um meio excepcional: misticismo..." (Ades: 1988, p. 174).
} 


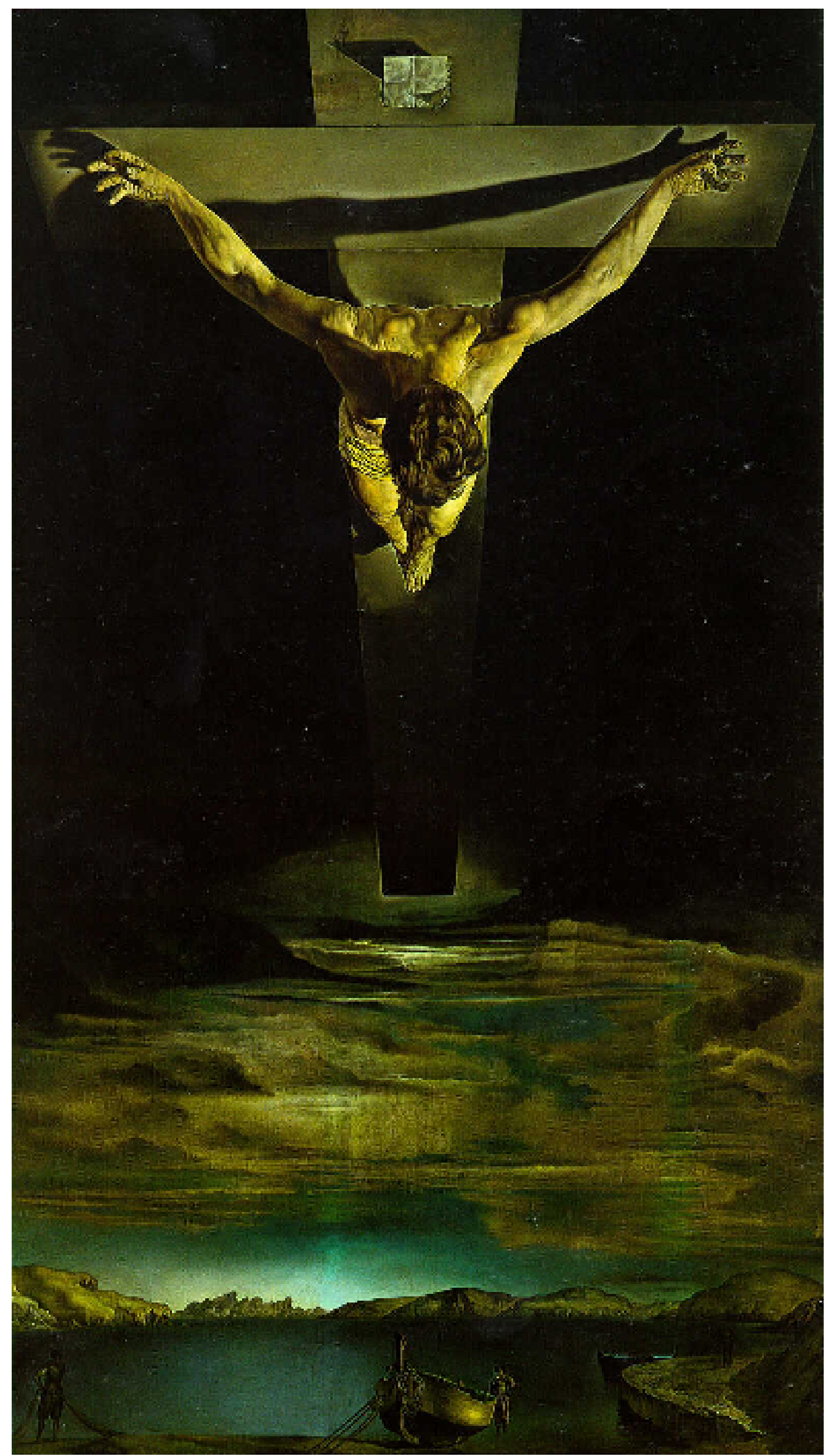

63. Salvador Dali. Cristo de São João da Cruz, 1951. Museu e Galeria de Arte de Glasgow. 
Dali, embora não tenha pesquisado a fundo, ao que tudo indica, os desdobramentos da quarta dimensão, ele já tinha uma concepção, digamos, mais atualizada dela, a que revolucionou nossa idéia de tempo e de espaço. Por exemplo, em seu livro Oui 2. L'archangélisme Scientifique de 1971, ele aponta em Psicologia não Euclidiana de uma Fotografia, que Kant não somente considera o tempo e o espaço como duas coisas diferentes, mas ainda como duas coisas de origem totalmente diferentes. O espaço é a forma intuitiva do mundo exterior e o tempo a forma intuitiva do mundo interior. E nós teríamos, sempre, um espaço e um tempo igualmente absoluto; “(...) esse estado de coisas é totalmente liquidado pela teoria da relatividade, que não há nem espaço nem tempo absolutos, e que só a união do tempo e do espaço tem uma significação física" (Dali: 1971, p. 53).

É numa obra desse chamado período místico que Dali pinta Crucificação: Corpus Hypercubos. Aí está a referência direta à quarta dimensão espacial! Podemos perceber que além da representação fugir às representações que estamos acostumados do Cristo crucificado, digamos, as mais convencionais, Dali utiliza o hypercubo, elemento clássico da quarta dimensão. Dali pinta esse quadro sob influência direta de um arquiteto espanhol do século XVI, que escreveu um Discurso sobre a Forma Cúbica.

A idéia, ao pintar Corpus Hypercubos, era a de oferecer um Cristo que seria a absoluta antítese do Cristo materialista e anti-místico de Grünewald. Apesar dessa referência a Grünewald, Dali não deixa claro porque o Cristo desse artista é antimístico. Pelo que explica Gombrich, a intenção de Grünewald era fornecer um sermão em ilustrações, proclamar as verdades que eram ensinadas na igreja. 0 painel mostra que ele sacrificou, segundo Gombrich, todas as considerações em função de um único fim, a uma finalidade transcendente. "Quanto à beleza, tal como os artistas italianos a concebiam, ele inexiste no quadro desolado e cruel do Salvador crucificado" (Gombrich: 198, p. 269).

Voltando a Dali, o Cristo crucificado flutua enquanto Nossa Senhora - que na realidade é Gala - contempla, aparentemente distante. A impressão que temos, ao olhar para a tela é que o Cristo está passando por ela. Parece que ele veio do fundo! É um quadro de muita beleza, mas ao mesmo tempo extremamente inquietante. 


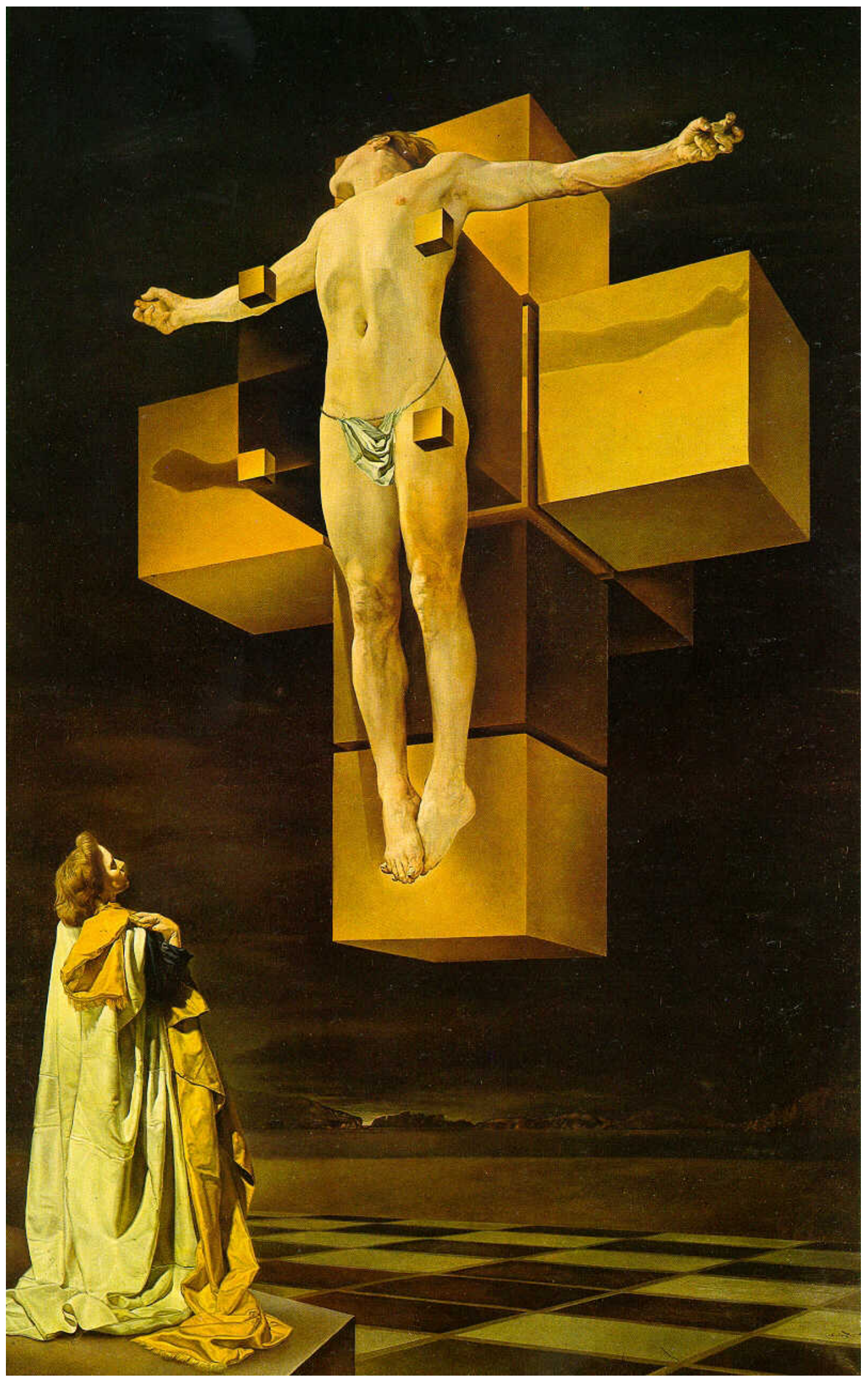

64. Salvador Dali. Crucificação - Corpus Hypercubos, 1954. Museu Metropolitano de Arte. Nova Iorque. $\mathrm{http} / / / \mathrm{www}$. dali-gallery.com/html/galleries.htm 
Enfim, no caso de Salvador Dali as questões envolvendo a quadrimensionalidade serviam a um fim criteriosamente determinado: o misticismo. Assim como Marcel Duchamp, Salvador Dali se interessa pela Teoria da Relativida Geral, pelo novo objeto que desponta por meio da Física, espaço-tempo. Acreditamsos que nem um dos dois artistas tenham conseguido representar em suas obras a quarta dimensão temporal.

\subsection{A Quadrimensinalidade Temporal}

Ao falarmos sobre a quarta dimensão devemos ter clareza de sua natureza, ou seja, se estamos nos referindo a uma quarta dimensão espacial ou a uma quarta dimensão temporal. Pois foi somente com a popularização da Teoria da Relatividade Geral de Einstein, redefinindo a quarta dimensão como tempo em vez de espaço, que aparentemente passamos a ter mais segurança para lidar com tal fenômeno. Portanto, o tempo passa a ser um tópico significativo e que merece ser levado em consideração, uma vez que ele, agora, interfere no espaço. Em função dessa nova estrutura teórica, não devemos acreditar, no entanto, que a quarta dimensão é apenas a inclusão de uma quarta variável $t$ às três variáveis de espaço $x, y, z$, ou seja, simplesmente acrescentar o tempo à altura, à largura e ao comprimento. Tratase de um termo muito restrito! Existe uma significação real e bem precisa que ultrapassa a simples idéia de uma quarta variável. O termo dimensão, na realidade, está ligado a uma idéia de ordem. Segundo Eddington, a ordem dos eventos na natureza segue uma ordem quadrimensional indissolúvel. "Podemos dividir arbitrariamente em espaço e em tempos da mesma maneira que nós podemos dividir a ordem do espaço em altura, largura e profundidade. Mas o espaço sem o tempo é tão incompleto quanto uma superfície sem espessura (Eddington: 1921, p. 19).

Em um artigo muito interessante, Jennifer Gimmell observa que muitos historiadores da arte tentam estabelecer relações entre a Teoria da Relatividade e a parte teórica do movimento Cubista. Nenhum deles observou que, na realidade, nunca houve contato entre os dois campos, assim como há diferenças marcantes tanto na literatura científica quanto na teorização cubista. A idéia de que as imagens fragmentadas das pinturas cubistas de alguma maneira incorporaram os elementos 
das equações de Einstein e, em função desta incorporação, conseguiram fazer com que as pessoas mudassem seu modo de pensar o espaço é, de acordo com Gimmell, questionável.

Segundo Gimmell, verificando a literatura cubista, não encontraremos nenhuma referência a Einstein, a Minkowski e nem à Teoria da Relatividade. Mesmo se os artistas cubistas estivessem atentos à esta teoria, é improvável que a negação da simultaneidade absoluta em Einstein fosse fonte de encorajamento para os pintores cubistas mostrarem várias perspectivas de um objeto ao mesmo tempo ou mesmo pintar vários objetos juntos. Gimmell relata que o próprio Einstein declarou em uma carta, que a nova linguagem artística dos cubistas nada tinha em comum com a Teoria da Relatividade. Além do mais, Gimmell nos dá outras provas de que não há nenhum documento que possa ligar o cubismo a Einstein. Primeiramente, até 1908 não havia nenhuma referência ao termo quarta dimensão na Teoria da Relatividade, assim como a geometria não-Euclidiana só apareceria por volta de 1916. Outro fato relevante é que Einstein só emergiu como celebridade em 1919, quando suas teorias sobre a massa gravitacional do Sol começaram a ser provadas experimentalmente. Em 1920 Einstein ganhou o Prêmio Nobel de Física, fazendo com que seu nome novamente voltasse às manchetes de jornais. Sendo assim, "é seguro dizer que a Teoria da Relatividade de Einstein não poderia ter tido nenhum impacto sobre os artistas franceses até o início para o meio de 1920. A Teoria da Relatividade não teve impacto sobre o Cubismo Analítico e muito menos sobre o Cubismo Sintético, pois ambos já estavam bem estabelecidos naquela época" (Gimmell: 2002, p. 08). Mas Henderson já havia feito tal observação! Embora a autora não mencione a Teoria da Relatividade, ela diz que "(...) não há nenhuma relação entre a geometria n-dimensional e o desenvolvimento da arte de Picasso e Braque. A arte de Picasso foi o produto de seu próprio gênio artístico na busca de alternativas à tradição figurativa clássica e ao espaço perspectivo do Renascimento" (Henderson: 1983, p. 58).

Ora, seguindo o raciocínio de Gimmell, assim como Apollinaire utilizou o termo quarta-dimensão de maneira metafórica, ou seja, sem nenhuma preocupação com o sentido matemático de suas implicações, podemos inferir que as investigações Cubistas foram mal-interpretadas. Assim, apesar da utilização de termos como simultaneidade e quarta-dimensão, por parte dos Cubistas, não há relação com os termos da moderna ciência e o espaço-tempo continuum de 
Minkowski. Enfim, como observa a própria Gimmell, embora os Cubistas tenham se valido do termo quarta-dimensão, seu significado se afasta da significação científica do mesmo termo. A quarta-dimensão, na acepção dos cubistas, foi, principalmente, um meio que permitiu aos artistas obterem uma idéia mais concreta do objeto no que diz respeito a sua dimensionalidade total.

É importante observarmos que o Cubismo nascera em um período de intensos questionamentos, um período em que a possibilidade de uma quartadimensão tornou-se imediata, porém uma quarta-dimensão espacial, não-Euclidiana. O fato de que muitas perspectivas foram apresentadas em Les Demoiselles d'Avignon, por exemplo, fundindo o temporal e o espacial, além de imprimir um caráter de simultaneidade à obra, não pode ser utilizado para justificar uma suposta quadrimensionalidade inerente às obras cubistas. O fato de haver a fusão do espaço e do tempo não quer dizer que os dois passaram a formar um só objeto - espaçotempo. Um dos aspectos mais reveladores do Cubismo é o fato de que, segundo Gimmell, sua arte não apresenta o tempo seqüencial de maneira implícita nem de maneira explícita. Em uma pintura cubista não existe momento seguinte porque simplesmente não há tempo seqüencial. "O gênio do Cubismo é que ele permite ao observador escapar desse "sistema de referência" tridimensional espacial as quais o mundo é tão dependente" (Gimmell: 2002, p. 12).

Ora, se quarta-dimensão não é apenas a inclusão de uma quarta variável $t$ às três variáveis de espaço $x, y, z$, mas trata-se, na realidade, de um termo que está ligado a uma idéia de ordem, uma ordem quadrimensional indissolúvel. O que seria, de fato, essa quadrimensionalidade temporal? De acordo com Hawking, "temos que aceitas o fato de que o tempo não é completamente separado e independente do espaço, mas que se combina com ele para formar um objeto chamado espaçotempo" (Hawking, 1997, p. 34). Portanto, o desafio dos artista que eventualmente se dedicarem à quarta dimensão parece ser uma tarefa muito complicada, pois já não basta utilizar uma figura geométrica, como o hipercubo, e o problema estaria resolvido. O desafio seria incluir o tempo à altura, à largura e ao comprimento!

Não há analogia e provável relação com o dinamismo futurista. Segundo Argan, para os futuristas o movimento é velocidade, é uma força física que deforma os corpos até o limite de sua elasticidade, relevando o dinamismo invisível da sua causa. Em outros termos, o movimento é uma condição objetiva que dá ao objeto em movimento uma forma diferente da do objeto imóvel. Logo, o que os futuristas 
fizeram não foi explorar a quarta dimensão, o tempo, em associação ao novo objeto espaço-tempo da Teoria da Relatividade Geral. Talvez alguns artistas resgatem essas questões e desenvolvam novas proposições. 


\section{IV}

\section{Para todas as Coisas, Números Digitais}

\subsection{Números Grandes}

Os números são símbolos que utilizamos nas mais diferentes situações, uma vez que nos referimos aos objetos de maneira quantitativa sem, na grande maioria das vezes, fazermos referência ao conceito que cada objeto traz consigo. Não nos damos conta de que, em nossas sociedades, o sentido da quantidade domina nitidamente o da qualidade. $\mathrm{Na}$ verdade, do ponto de vista cotidiano, não concebemos os números sob o ângulo da abstração, como fazem ainda hoje os primitivos zulus e pigmeus, da África; os arandas e kamilarais, da Austrália; os aborígines das ilhas Murray e os botocudos, do Brasil. Digamos, no entanto, que isso acontece em um nível mais imediato do cotidiano; contudo, em um nível abstrato, essa relação toma outro rumo. Por exemplo, antes, para designar um número grande, utilizávamos o "milhão"15. Mas as coisas mudaram!

O que terá acontecido conosco daqui a cinco milhões de anos ou daqui a cinco bilhões de anos? Certamente estaremos mortos! Outro exemplo dessa necessidade diz respeito à velocidade com que o universo está se expandindo. Como aponta Margareth Wertheim, a escala de expansão cósmica é algo verdadeiramente desconcertante. Wertheim relata que, segundo o físico Paul Daves, a região do universo acessível a nossos telescópios se dilata a cada dia em $10^{18}$ anos-luz cúbicos. Isto significa que o espaço, em um único dia, expande-se a uma velocidade de um bilhão de bilhões de anos-luz cúbicos (Wertheim: 2001, p. 129). Para os físicos tais números fazem sentido, ou melhor, são essenciais. Na realidade, os físicos precisam de números grandes assim, pois lidam com medidas estratosféricas. 


\subsubsection{Milhões, Bilhões, Trilhões}

$\mathrm{Na}$ verdade, o milhão e o bilhão vêm perdendo espaço para um número que, segundo Sagan, é muito mais elegante: o trilhão ${ }^{16}$. São números realmente grandes! Para representá-los, os cientistas e matemáticos utilizam um método inequívoco que se constitui de contar os zeros depois do número 1; ou seja, 1 trilhão é 1.000.000.000.000. Mas há um modo mais fácil de representar números grandes, basta utilizar os expoentes ou potências. Sendo assim, $10^{12}$ quer dizer 1 trilhão ${ }^{17}$.

Bilhão e trilhão talvez não sejam números tão relevantes para nossas vidas (pelo menos para a maioria dos mortais). Só para termos uma vaga idéia, se iniciássemos, a partir do 0 , um número por segundo, dia e noite, levaríamos 32 anos para contar 1.000.000.000 (bilhão); e 32 mil anos para contar 1.000.000.000.000 (trilhão) - mais tempo do que a idade da civilização sobre a Terra ${ }^{18}$. Se por um lado bilhão e trilhão são números totalmente distantes de nosso cotidiano, os algarismos que os compõem não o são: 0 e 1. Para acompanharmos a história das numerações é necessário seguir o caminho que separa o Um do Zero, conceitos que se tornaram os símbolos de nossa sociedade técnica. Hoje em dia encaramos a passagem do zero à unidade com a maior naturalidade, no entanto, como aponta Ifrah, foi um passo de um hipergigante temporal (Ifrah: 1997, p. xvi). Logo, esses dois números nos acompanham desde a nossa mais tenra idade sem que saibamos suas origens. Tais indagações, à primeira vista, podem parecer desnecessárias, mas, na verdade, são fundamentais para o entendimento de uma estrutura muito maior: a fantástica história da inteligência humana.

\subsubsection{Do Zero ao Um}

O zero pode assumir dois papéis bem diferentes: o de número e o de numeral. Como um número ele indica uma quantidade. Por exemplo: se em uma determinada estante há zero livros, isso quer dizer que não há nada em suas prateleiras. Portanto, o zero (número) indica uma quantidade nula, um nada. Já como um numeral o zero é utilizado em sistemas numéricos que indicam um valor ao dígito que o precede ou que o sucede.

O registro da utilização do número zero dá-se mais de dois séculos depois da primeira referênca aos nove outros numerais. Na realidade não se sabe se o número zero surgiu em conjunção com os outros nove numerais hindus. "É bem possível que 
o zero seja originário do mundo grego, talvez de Alexandria, e que tivesse sido transmitido à Índia depois que o sistema decimal posicional já estava estabelecido lá" (Boyer: 1996, p. 145). O conceito apareceu independentemente, bem antes dos dias de Colombo, no hemisfério ocidental como no oriental.

Como sustenta Boyer, a forma para o símbolo zero surge com a forma do símbolo hindu para zero. A forma "(...) redonda vinha da letra grega ômicron, letra inicial palavra ouden ou vazio, mas investigações recentes parecem desmentir tal origem" (Boyer: 1996, p. 147). Segundo Boyer, embora o símbolo para uma posição vazia, em algumas versões existentes das tabelas de cordas de Ptolomeu, assemelhe-se de fato a um ômicron, os antigos símbolos para o zero nas frações sexagesimais gregas são formas redondas com ornatos variados e diferindo bastante de um simples ovo de ganso. Além disso, quando no século $X V$, no Império Bizantino, foi elaborado um sistema decimal posicional a partir dos antigos numerais alfabéticos, abandonando as últimas 18 letras e ajuntando um símbolo para o zero às primeiras nove letras, o sinal zero tomou formas muito diferentes do ômicron. Às vezes ele parecia uma forma invertida de nossa letra $\mathrm{h}$ minúscula, às vezes aparecia como um.

O número um está ligado a um tempo em que as pessoas ainda não sabiam contar, mas isso não significa que eles não tinham nenhuma noção dos números, e sim essa noção estava limitada àquilo que os sentidos eram capazes de perceber com uma rápida olhada. Tratava-se, na verdade, de um conceito que exprimia uma realidade concreta e inseparável dos objetos, que se manifestava somente com a percepção direta de sua pluralidade física (Ifrah: 1985, p. 5). Devido a essa peculiaridade, os primeiros conceitos numéricos inteligíveis do ser humano são o um e o dois. Segundo Ifrah, o número um esteve associado ao homem ativo, à obra da criação; é também o símbolo do homem em pé, o único ser vivo dotado dessa capacidade, como também do falo ereto que distingue o homem da mulher. Já o número dois corresponde à evidente dualidade entre o feminino e o masculino, à simetria aparente do corpo humano. É também o símbolo da oposição, da complementaridade, da divisão, da rivalidade, do conflito ou do antagonismo (Ifrah: 1998, p. 17). 
Se acompanharmos a história da humanidade e a história dos números, verificaremos que o desenvolvimento das duas está intimamente ligado a necessidades e preocupações das culturas e dos grupos sociais mais diversos, uma vez que foi procurando contar os dias, concretizar trocas e transações, enumerar esposas, mortos, bens, rebanhos, soldados etc. que o homem viu-se diante da emergência de uma série de avaliações numéricas. Como postula Ifrah, além do domínio do fogo, do desenvolvimento da agricultura ou do progresso do urbanismo e da tecnologia, dois acontecimentos foram extremamente revolucionários: a invenção da escrita e a invenção do zero e dos algarismos arábicos, os quais modificaram completamente a existência do ser humano.

A história da descoberta dos algarismos começou há mais ou menos cinco mil anos em certas sociedades avançadas, em pleno processo de expansão, para fixar operações econômicas excessivamente numerosas e variadas para serem confiadas exclusivamente à memória humana. Mas alguns sistemas mostraram-se impraticáveis.

\subsubsection{Máquinas de Calcular}

Calcular sempre esteve entre as preocupações mais imediatas do ser humano, embora tenha demandado grandes esforços. As palavras de um matemático italiano chamado Menabrea servem para ilustrar esse tipo de pensamento. Vejamos:

\footnotetext{
"Quantas observações preciosas (...) permanecem inúteis para o progresso das ciências e das técnicas porque não há forças suficientes para calcular os seus resultados! Entretanto, é pela via laboriosa da análise que ele tem de chegar à verdade. Mas ele não pode persegui-la se não é guiado pelos números, pois sem os números não é possível levantar o véu que esconde os mistérios da natureza" (apud Ifrah: 1998, p. 329).
}

De acordo com Ifrah, o astrônomo alemão Wilhelm Schickard (1592-1635) foi o pioneiro na construção de uma máquina de calcular. Em 1623 ele construiu seu relógio de cálculo, ou seja, uma máquina capaz de executar as quatro operações segundo princípios puramente mecânicos para a adição e a subtração e, segundo várias intervenções, a subtração e a divisão. Mas foi em 1642, com o filósofo e 
matemático francês Blaise Pascal (1623-1662), que houve de fato um avanço considerável no terreno dos cálculos mecânicos. Pascal construiu uma máquina chamada Pascalina cuja finalidade foi a de simplificar os intermináveis cálculos efetuados com o ábaco para as contas de seu pai, então superintendente da generalidade de Rouen. "A principal característica da máquina de Pascal residia no transporte automático das somas, cujo princípio estava fundado em um dispositivo mecânico composto de uma série de rodas dentadas, numeradas de 0 a 9 , e ligadas de tal maneira que a rotação completa de uma delas faria avançar a seguinte em um dente" (Ifrah: 1997, p. 600).

A Pascalina, na verdade, não foi uma máquina de calcular infalível, pois o saltador - órgão essencial da máquina - engrenava muito mal nas barras da lanterna que deveria governar; a transferência automática da soma ficava comprometida, pois um determinado mecanismo era bloqueado quando várias rodas indicavam simultaneamente.

Foi o matemático e filósofo alemão Gottfried Wilhelm Leibniz quem elaborou mecanismos que permitiriam executar operações por adições e subtrações sucessivas. A máquina de Leibniz, segundo postula Ifrah, tinha a capacidade de executar operações aritméticas elementares por meios puramente mecânicos. Com isso, sua máquina acabou trazendo um número expressivo de novos conceitos, tais como:

\footnotetext{
“(...) um inscritor permitindo colocar um número antes de adicioná-lo; um visor de posição; um acionador; um carro permitindo a adição e a subtração em uma posição fixa, a multiplicação em posição móvel orientada para a esquerda e a divisão em posição móvel orientada para a direita; um sistema de tambores dentados com comprimento crescente deslizando cada um sobre seu eixo e substituindo dez roldanas independentes etc. (Ifrah: 1997, p. 603).
}

Ora, a partir das contribuições de Leibniz, muitos outros inventores acrescentariam melhorias à sua obra. Por exemplo, a máquina do italiano Giovanni Poleni (1709), marcada pela invenção da roda dentada com número variável de dentes; a do austríaco Antonius Braun (1727); a do alemão Jacob Leupold, concebida por ele próprio em 1727 e depois melhorada em 1728 por Antonius Braun e construída em 1750 por um mecânico denominado Vayringe; a máquina do alemão Phillipp Mattaüs Hahn, elaborada em 1770 e depois construída em série de 
1774 a 1820; as duas calculadoras do inglês Lord Stanhope (1775 e 1777); a máquina do alemão Johann Hellfried Müller (1782-1784) (Ifrah: 1997, p. 603). Mas foi a partir da utilização dos computadores que o homem percebeu que há determinados cálculos que ele nunca conseguiria fazer sozinho.

Algumas curiosidades acerca de cálculos demorados feitos pelo homem, sem o auxílio do computador, giram em torno do número $\pi$. No século VI os chineses chegaram a determinar seis decimais do número $\pi$, e nove séculos depois 0 matemático muçulmano Ghiyat dîn Ghamhîd al Kâshî calculou 16. Em 1719, o francês Fantet de Lagny calculou 127 casas decimais. Já em 1794, o barão Geor von Veja forneceu 136 casas decimais. O fato mais curioso relacionado ao número $\pi$ relaciona-se ao inglês William Shanks, que realizou o recorde absoluto de cálculo humano. Ele demorou 19 anos para fornecer 707 primeiras decimais do número $\pi$.

No pós-Guerra, com a automatização do cálculo, o tempo para determinar, e aumentar, as decimais do número diminuíram. Em 1947 D. F. Ferguson e J. Wrench Jr. conseguiram determinar 808 decimais de $\pi$ em alguns meses de trabalho, utilizando uma calculadora automática de escritório. Com o desenvolvimento das grandes calculadoras analíticas e com seus avanços tecnológicos, o desempenho tornou-se impressionante. Em 1949 George Reitwisner calculou 2.037 decimais do número $\pi$ em menos de 70 horas em uma calculadora eletrônica chamada Eniac. Com a aparição dos computadores eletrônicos e com seu posterior avanço tecnológico - cada um mais acelerado -, os cálculos tornaram-se não somente mais rápidos, mas também, e sobretudo, muito mais ousados. Em 1954 S. Nicholson e J. Neenel determinaram 3.089 decimais no IBM Norc em 12 minutos. Em 1958 F. Genuys calculou 10.000 em uma hora e 40 minutos em um IBM 704. Em 1961 Daniel Shanks calculou "pouco mais de 100.000 em nove horas em um IBM 7.090. E, recorde absoluto da época, em 1976 J. Guilloud e M. Boyer determinaralm um milhão em pouco mais de duas horas em um CDC 6.600" (Ifrah: 1997, p. 591 v. 2).

\subsection{Digitalização Global}

Um objeto digital é composto por um meio físico e por uma parte digital. O meio físico se encarrega de transmitir, armazenar e apresentar a obra digital. Sua 
parte digital é composta por uma máquina geradora e por uma parte que é lida pelo homem, criado por computador a partir de um arquivo digital. Como o ser humano ainda não é capaz de entender uma série de signos binários gravados por uma máquina, é necessário que esses sinais sejam convertidos em códigos que possam ser lidos por humanos. Segundo Betancourt (2006, p. 02), os objetos digitais possuem a mesma singularidade: um código binário. Essa forma básica faz que o objeto digital seja fundamentalmente diferente de qualquer tipo de objeto físico, uma vez que ele perde a única característica que define as diferenças entre pinturas, desenhos, livros, sons ou qualquer outro objeto físico ou fenômeno. Enfim, diferentemente dos objetos físicos, os objetos digitais são basicamente os mesmos, não importando sua aparência, uma vez que eles são interpretados por uma máquina.

Um objeto digital pode ser reproduzido infinitamente sem jamais perder suas qualidades, pois uma cópia não é somente equivalente em conteúdo, mas é idêntica à sua origem. Sendo assim, o conceito de original desaparece, porque todas as versões serão originais idênticos, ou melhor, serão cópias idênticas. Segundo Walter Benjamin, a reprodução técnica destituiria os objetos artísticos de sua "aura mágica". Como bem observa Betancourt, seria estranho se a reprodução técnica não reduzisse o glamour, o charme das obras de arte - embora isso não tenha acontecido! A reprodução técnica, na realidade, ajuda a expandir a aura das obras de arte. Esta interpretação invertida de "aura", produzida em função da acessibilidade e disponibilidade da obra de arte, desloca a ênfase dada por Walter Benjamin do culto ao valor do objeto artístico para seu valor comercial de troca. Segundo Betancourt, o realce ao que Walter Benjamin chamou de papel tradicional da obra de arte está em seu conceito de aura física do objeto, em sua autenticidade. Mas, para ela, a autenticidade de alguma coisa, sua essência, é tudo aquilo que é transmissível desde o início, que vai de sua duração substantiva a seu testemunho histórico. A idéia de autenticidade, portanto, só começa a ter valor significativo uma vez que há de fato reproduções de obras de arte - similares em aparência, mas não idênticas à sua origem.

quanto mais uma obra de arte é promovida através de reproduções, mais é possível supor que sua "aura" aumentaria também. (...) "aura" não é como Benjamin propôs, mas, pelo contrário, é uma função do processo reprodutivo em 
si. Essa mudança na concepção de "aura" de Benjamin sugere que os objetos artísticos têm um caráter duplo. A "aura" está tanto no traço físico da história particular do objeto quanto na relação desse objeto com a tradição que o produziu. Estes são dois valores distintos: um reside no objeto físico, o outro está no conhecimento que o espectador (e em sua experiência passada) tem da relação com outros objetos similares. Se o primeiro valor é um "testemunho histórico", o segundo valor pode ser chamado de "relação simbólica"” (Betancourt: 2006, p. 03).

Objetos digitas são armazenados como uma forma de informação. A reprodução digital é diferente de qualquer tipo de reprodução anterior a ela porque suas "cópias" serão, sempre, exatamente idênticas, e os objetos digitais sujeitos a esse tipo de reprodução podem ser vistos como uma nova classe de objetos.

Esta situação fica mais evidente com exemplos. Algumas experiências históricas foram comuns a toda a Europa, pois promoveram os principais temas da história no século passado - liberalismo, imperialismo, fascismo, socialismo, comunismo. Hoje, com o advento das novas tecnologias, a experiência comum, não só à Europa, mas praticamente ao mundo todo, tem sua raiz, como postula Monet, numa acentuada tendência de digitalização global de nossa sociedade e dos nossos modos de intercâmbio. Assim, a própria cultura que deriva dessa digitalização passará a mediar os principais temas desse século. Com a digitalização progressiva de todo tipo de informação é inegável que novas estruturas influenciarão nossas condições de vida. Mas, como muito bem observa Monet, o ser humano, pelo menos por enquanto, ainda não compreende o binário, pois uma seqüência de 0 e 1 não significa absolutamente nada para ele. Na verdade, todos os equipamentos digitais têm de fornecer a informação sob uma forma analógica. E ele dá o seguinte exemplo:

"Quando telefonamos, a nossa voz provém das vibrações de cordas vocais. Sendo sua forma analógica (mais ou menos forte, mais ou menos aguda etc.) será digitalizada pelo telefone ou pela central telefônica. Sob o estado de 0 e 1 , navega então pelo fio que nos liga ao nosso correspondente. Mas como o ouvido humano não pode decodificar esta linguagem binária (ou antes, estes impulsos elétricos que descrevem a nossa voz em formato binário), é necessário que a nossa mensagem seja restituída sob a única forma que o aparelho auditivo humano reconhece: a forma analógica. À chegada, o auscultador emitirá vibrações que afetarão mais ou menos o tímpano, recriando desse modo sons familiares. A nossa mensagem passa então por uma seqüência: analógica (a nossa voz), digital 
(percebido e tratado pela rede telefônica), analógica (compreendido pelo ouvido humano)" (Monet: 1995, p. 15).

Ora, se um conjunto de dados é, na realidade, uma seqüência de números, apenas isso, cada filme digital, cada imagem, cada som é, em última instância, nada mais do que uma seqüência de zeros e uns armazenados na memória de um computador. Aquilo que "havia sido feito no rádio e na televisão traduzindo o som e a imagem em ondas eletromagnéticas, o computador o faria doravante traduzindo as mensagens em símbolos matemáticos (Couchot: 2003, p. 33). Isso serve também para a Inteligência Artificial ( $\mathrm{Al}$ ), em que o numérico também está presente; ou seja, chega a imitar, o máximo possível, por meio de máquinas eletrônicas, a atividade mental humana - talvez superá-la. Segundo Penrose, uma área em que teria um impacto relevante seria a psicologia, porque, ao imitar o comportamento de um cérebro humano por meio de ferramentas eletrônicas, poderíamos aprender como ele funciona. Com isso, a atividade mental passa a ser vista simplesmente como uma seqüência de operações algorítmicas muito bem definida (Penrose: 1990, p. 22).

\subsubsection{Numérico ou Numerização}

Quando falamos em digital estamos, portanto, falando também em números, em numerização, uma vez que tudo passa a ser números novamente. Como já demonstramos, Pitágoras, por volta do século VI a.C., chegara à conclusão de que todas as coisas são números. Para os pitagóricos os números eram a própria alma das coisas, "são entidades corpóreas constituídas pelas unidades contíguas. Assim, quando os pitagóricos falam que as coisas imitam os números, estariam entendendo essa imitação (mimesis) num sentido perfeitamente realista: as coisas manifestariam externamente a estrutura numérica que Ihes é inerente" (Os Pensadores: 1973, p. xxiv).

A tomada de consciência do papel fundamental que os números desempenham nas ciências de hoje levou Bertrand Russell a afirmar que o mais surpreende na ciência moderna é seu retorno ao pitagorismo. Todavia, Ifrah adverte que esse retorno não deve ser entendido como uma retomada de seus aspectos místicos, que 
fizeram dos números um meio de aproximar as verdades e os segredos divinos. De acordo com Ifrah, Russell compreendeu que não são os números que reinam sobre o mundo, mas sim o universo, que "é regido antes pelas leis da natureza de um mundo físico que possui propriedades exprimíveis por conceitos abstratos, os números, eles próprios elaborados por um pensamento humano que, tendo chegado ao estágio da abstração última, efetua um trabalho permanente sobre as coisas deste universo (Ifrah: 1997, p. 586). Embora Ifrah destaque um suposto lado místico, uma harmonia celeste, cósmica e interior, o fato de Pitágoras ter afirmado que tudo é número é curiosamente atual.

Ao afirmar que os números estão ocultos em tudo, é evidente que Pitágoras não estava fazendo nenhuma previsão relacionada à revolução digital, porém temos de admitir que os gregos mais uma vez nos surpreenderam! Todas as coisas são números, ou melhor, todas as coisas voltaram a ser número, só que desta feita no mundo digital, não mais analógico. Como observa Wertheim, para Pitágoras os números são arquétipos para o domínio material, uma vez que o número é a própria essência da forma. "Dois mil e quinhentos anos depois, o ciberespaço está sendo construído sobre essa premissa. A própria idéia de uma simulação ou modelos digitais baseados em computadores pressupõe que a forma pode ser apreendida na dança efêmera dos números. Esta é a essência da "realidade virtual"' (Wertheim: 2001, p. 198). Ora, os números codificados em binários podem ser objetos de cálculos aritméticos e lógicos executados por circuitos eletrônicos especializados; e as informações estão codificadas como números que, por sua vez, podem ser manipulados com muita facilidade, logo, números estão sujeitos a cálculos, e computadores calculam muito rapidamente (Lévy: 1999, p. 53). Uma prova disso é que, segundo Negroponte, 64 mil bits por segundo são mais do que suficientes para música de alta fidelidade; e 45 milhões de bits por segundo é um número fantástico para imagem em vídeo.

"Há cinco anos, grande parte das pessoas não acreditava na possibilidade de se reduzir, sem qualquer perda, para 1,2 milhão os 45 milhões de bits por segundo necessários para o vídeo digital. Em 1995, porém, somos capazes de comprimir e descomprimir, codificar e decodificar imagens em vídeo a essa taxa, e isso de forma barata e com alta qualidade" (Negroponte: 1995, p. 22). 
A numerização é a possibilidade técnica de tratar de maneira indistinta tanto o texto e o som quanto a imagem, sendo que sua materialidade é uma matriz de números capaz de informar ou de modular independentemente do suporte. Ela altera um simbólico universal, pois todos os símbolos podem ser transformados em uma seqüência de zeros e uns e, reciprocamente, essa mesma seqüência pode tornar-se - após um tratamento - fala, som, música, pintura, desenho, escrita ou mesmo um ruído. Conforme observa Musso, no entanto, o objeto, a partir do momento em que é digitalizado, perde a semelhança com o referente de origem. Mas o que "importa é o programa que faz surgir o objeto, quer dizer, o jogo de números e de códigos, as combinações e as matrizes que se "materializam" e "dão vida" (...)" ( Musso: 1991, p. 104).

\subsubsection{Os Algoritmos}

A palavra 'algoritmo' deriva do nome do matemático persa Abu Já'far Mohammed ibn Musâ al-Khowârizm, que escreveu um texto muito importante, por volta de 825 a.C., intitulado 'Kitab al-jabr wa'l-mugabala'. O modo como o nome 'algoritmo' veio a ser pronunciado, ao invés do anterior e mais preciso 'algorismo', parece ter sido devido à associação com a palavra 'álgebra'. (Penrose: 1990, p. 26).

De acordo com Penrose, exemplos de algoritmos eram conhecidos muito antes do livro de al-Khowârizm. Um dos mais familiares, datando dos tempos da antiga Grécia (c. 300 a.C.), trata-se do procedimento conhecido por algoritmo de Euclides, que pode ser utilizado para determinar o maior fator comum ente dois números ${ }^{19}$. Um algoritmo, pois, é uma seqüência de instruções, não ambígua, que deve ser executada até que uma determinada condição se verifique.

Para qualquer processo computacional, o algoritmo precisa estar rigorosamente definido, ou seja, especificada de que maneira o computador deve se "comportar" em determinadas circunstâncias. A corretude do algoritmo pode ser provada matematicamente, bem como a quantidade de tempo e espaço necessários para a sua execução. A maneira mais simples de se pensar um algoritmo é por meio de uma lista de procedimentos bem definida, cujas instruções devem estar bem especificadas, passo a passo, do começo ao fim da lista. Ora, da mesma maneira que precisamos de programas específicos para que o computador faça qualquer 
coisa para nós, é necessário também que hajam algoritmos para que os computadores saibam como cumprir certas tarefas. Ou seja, é a técnica elementar utlizada para dar ordens aos computadores.

Vejamos os exemplos a seguir:

- O algoritmo do táxi:

1. Vá para o ponto de táxi;

2. Entre em um táxi;

3. Dê meu endereço ao motorista.

- $\quad 0$ algoritmo "ligue-me":

1. Quando seu avião chegar, ligue para meu celular;

2. Espere do lado de fora do terminal de bagagens.

- $\quad$ O algoritmo "alugue um carro":

1. Pegue o circular até o aluguel de automóveis;

2. Alugue um carro;

3. Siga as instruções para chegar até minha casa.

- O algoritmo do ônibus:

1. Fora do terminal de bagagens, pegue o ônibus número 70;

2. Faça uma baldeação para o ônibus 14 na Rua Dom Pedro;

3. Desça na Rua Aroeira;

4. Ande duas quadras para norte até minha casa.

Interessante notarmos que os quatro algoritmos são postulados para atingir exatamente o mesmo fim. No entanto cada um deles o faz de modo completamente diferente, além do fato de que cada um possui um custo diferente: o táxi é mais rápido, porém mais caro; o ônibus é muito mais barato, mas lento. Enfim, podemos escolher o algoritmo de acordo com nossas necessidades. Cada 
algoritmo possui um custo e um tempo de viagem diferentes. Portanto, há vantagens e desvantagens com cada algoritmo em situações diferentes.

\subsubsection{Geometria Fractal}

Relembrando, Gauss, com o decorrer dos anos, se convencia cada vez mais da necessidade de uma alternativa à Geometria de Euclides. A mera possibilidade de que a soma dos ângulos internos de um triângulo seja menor do que $180^{\circ}$ conduziria a uma geometria curiosa, bem diferente da euclidiana. Mas a proposição mais inquietante foi a de Lobachevsky, segundo a qual por um ponto $\mathbf{P}$, fora de uma reta $\mathbf{r}$, passa mais de uma reta paralela à reta $\mathbf{r}$. Ou seja, entre as retas a e $\mathbf{b}$ passam infinitas retas, que não interceptam a reta $\mathbf{r}$.

A descoberta da Geometria não-Euclidiana teve impacto tão profundo que foi só após Einstein entender as sutilizas dessa nova Geometria que ele pôde formular matematicamente sua teoria da relatividade geral. Como vemos, em um dado momento a Geometria euclidiana se mostrou pouco eficaz quando aplicada a um espaço curvo. Algo semelhante aconteceu com uma outra Geometria, a Geometria Fractal. Ela é a mais indicada quando o propósito é buscar padrões dentro de um sistema aparentemente aleatório. Em outras palavras, como destaca Barbosa, na constituição do nosso mundo, dos oceanos, das montanhas e rios, rochas, plantas e animais etc., há componentes cujas formas são dominadas pela irregularidade; "tentar simplifica-las empregando formas usuais da clássica geometria euclidiana, como triângulos, círculos, esferas, cones etc., seria absurdamente inadequado. A geometria dos fractais pode fornecer aproximações para essas formas" (Barbosa: 2002, p. 10).

Podemos, pois, iniciar nossas investigações acerca dos fractais pelo significado da palavra fractal. Ela vem do adjetivo latino fractus, que quer dizer quebrar, criar fragmentos irregulares, fragmentar. Portanto, segundo Barbosa, quando dizemos Geometria Fractal estamos fazendo referência ao estudo de objetos irregulares e fragmentados. Ela busca, pois, padrões organizados de comportamento dentro de um sistema aparentemente aleatório.

Briggs relata o caso de Edward Lorenz, meteorologista do MIT (Massachusetts Institute of Technology) sobre a impossibilidade de realizar 
previsões do tempo precisa. Aparentemente tal constatação é contraditório, pois, teoricamente, quanto informações obtivermos sobre um determinado assunto, muito maiores serão nossas chances de obtermos resultados satisfatórios. Mas Lorenz, segundo Briggs, insistiu nessa: quanto mais informações sobre a velocidade do vento, pressão atmosférica, umidade do ar, etc. mesmo assim as previsões têm grandes chances de serem completamente equivocadas. O motivo para tal impossibilidade é que sistemas dinâmicos como o tempo são compostos de muitos elementos interativos que são tremendamente sensíveis, até mesmo os mais insignificantes.

O mais interessante disso tudo é o fato de que se não levarmos em consideração, por exemplo, o vento das asas de um mosquito que está em Madagascar, certamente impedirá que seja feito uma previsão do tempo com precisão. Isso quer dizer que, para espanto de muita gente, os sistemas são tão sensíveis que podem ser afetados por minúsculas que eventualmente estejam do outro lado do universo. Portanto, a natureza é dominada pelo caos, e não pela ordem! Enfim, como sustenta Briggs, a única maneira de conseguirmos informações suficientes para entender os fenômenos é incluirmos em nossas investigações até mesmo nossos esforços de reunir informações (Briggs: 1994, p. 16).

A conclusão imediata a que chegamos é: todas as coisas se influenciam mutuamente. Mas será que isso é, de fato, possível? Nós estamos, neste exato momento, sofrendo influência de algum minúsculo ser que habita outra galáxia a milhões de anos luz de distância da Terra? Segundo a Teoria do Caos, sim! Mas a Teoria da Relatividade Geral de Einstein tem uma explicação para uma situação bem próxima do fenômeno esboçado acima.

Imaginemos, segundo propõe Hawking, que um pulso de luz fora emitido num tempo de um ponto específico no espaço. À medida que o tempo passa, esse pulso de luz se espalhará como uma esfera. Após um milionésimo de um segundo aquele mesmo pulso de luz se espalhará para formar uma esfera com um raio de 300 metros; após dois milionésimo de segundos atingirá 600 metros. As ondulações formadas pelo pulso de luz se espalham em forma de um círculo que aumenta com o passar do tempo. Aquele pulso de luz inicial é, de acordo com Hawking, um evento presente. A luz, a partir desse evento presente, se espalha formando um cone tridimensional no espaço-tempo quadrimensional. 


\section{Cone de luz futura}

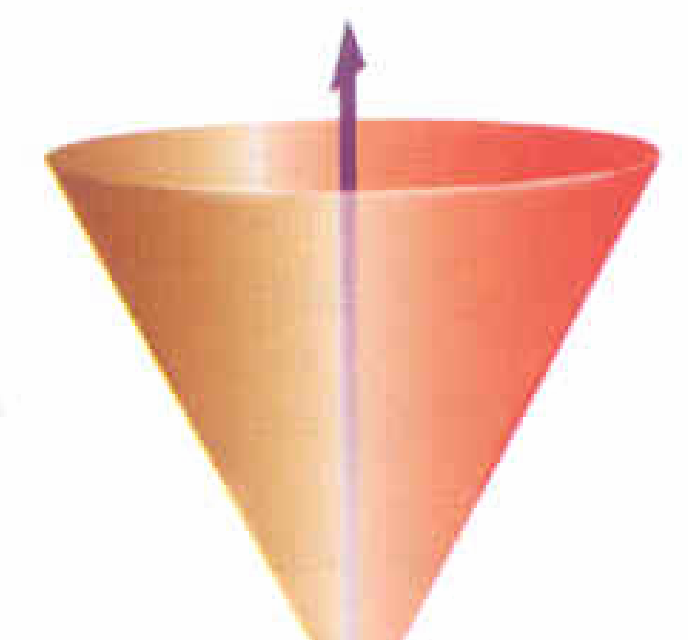

Evento presente $\mathrm{P}$

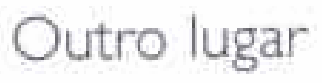

\section{Cone de luz passada}

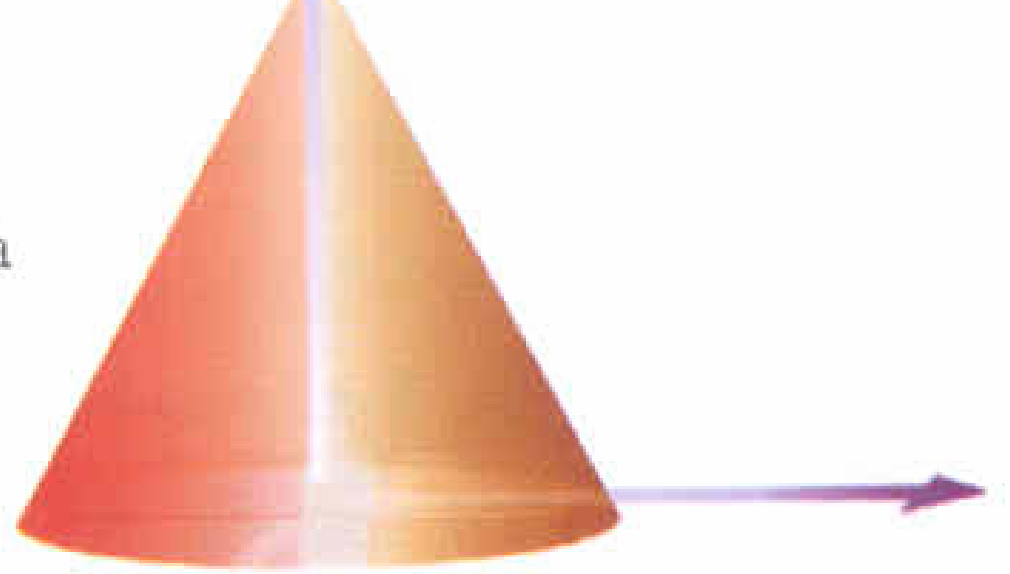

\section{Espaço}

65. Uma Breve História do Tempo, p. 34.

Conforme podemos observar na figura acima, esse cone é chamado de cone de luz futura e cone da luz passada de um evento. Segundo as demonstrações de Hawking,

Dado um evento $P$, podemos dividir os outros eventos no universo em três classes. Os eventos que podem ser alcançados do evento $\mathrm{P}$ por uma partícula ou onda que se desloca em velocidade igual ou inferior à da luz são tidos como contidos no futuro de $P$. Eles se situam dentro ou sobre a esfera em expansão da luz emitida do evento P. Assim, estão dentro ou sobre o cone de luz futura de $\mathrm{P}$ no diagrama espaço-tempo. Apenas os eventos no 
futuro de $\mathrm{P}$ podem ser afetados pelo que acontece em $\mathrm{P}$, porque nada pode se deslocar mais rápido que a luz. (...) Da mesma forma, o passado de $\mathrm{P}$ pode ser definido como sendo $\mathrm{o}$ conjunto de eventos a partir do qual é possível alcançar o evento $\mathrm{P}$, deslocando-se em velocidade igual ou inferior à da luz (Hawking: 1997, p. 38-39).

Voltando à Teoria do Caos, levando-se em consideração as proposições contidas na Teoria da Relatividade Geral, seria exagero acreditar que algo a milhões de anos luz da Terra pudesse nos afetar neste exato momento! Isso não poderia acontecer porque um evento somente me afetaria se eu fizesse parte do cone de luz futura. Talvez a Teoria do Caos funcione bem em sistemas sensíveis aqui na Terra, mas não no espaço-tempo de Einstein.

Um outro que gostaríamos de ressaltar é a estreita relação entre o numérico e os fractais, haja vista que eles estão intimamente ligados ao desenvolvimento e aprimoramento das técnicas computacionais. $\mathrm{Na}$ verdade os cientistas e matemáticos descobriram que poderiam gerar formas fractais em seus próprios computadores. Estamos, de modo geral acostumados com fractais digitais, criados por computador. Mas os fractais presentes na natureza são tão interessantes quanto os digitais e com propriedades muito significativas!

Notemos que na foto abaixo ao mesmo tempo em que o coração da galáxia whirlpoll segue uma curva logaritma, não podemos usar a geometria Euclidiana, pois estamos vendo uma imagem "caótica" em função de sua irregularidade. Richard F. Voss em Fractals in nature: From characterization to simulation reforça a idéia de que a geometria de Euclides é incapaz de descrever o mundo que apreciamos ultimamente. Segundo o autor, citando Mandelbrot, tal impossibilidade surge do fato de que nuvens não são esferas, nem montanhas são cones e muito menos a luz viaja em linha reta. Portanto é necessário que incorporemos um novo dialeto, segundo as palavras de Voss, pois um novo ramo da matemática desponta e é apropriada para as formas irregulares do mundo.

Ao ouvirmos falar de Fractais pensamos logo em imagens geradas por computador, sem nos darmos conta de que a natureza está repleta de formas irregulares, de fractais. Tanto é assim, que Mandelbrot lança um livro justamente abordando tias aspectos: Fractal Geometry of Nature. 


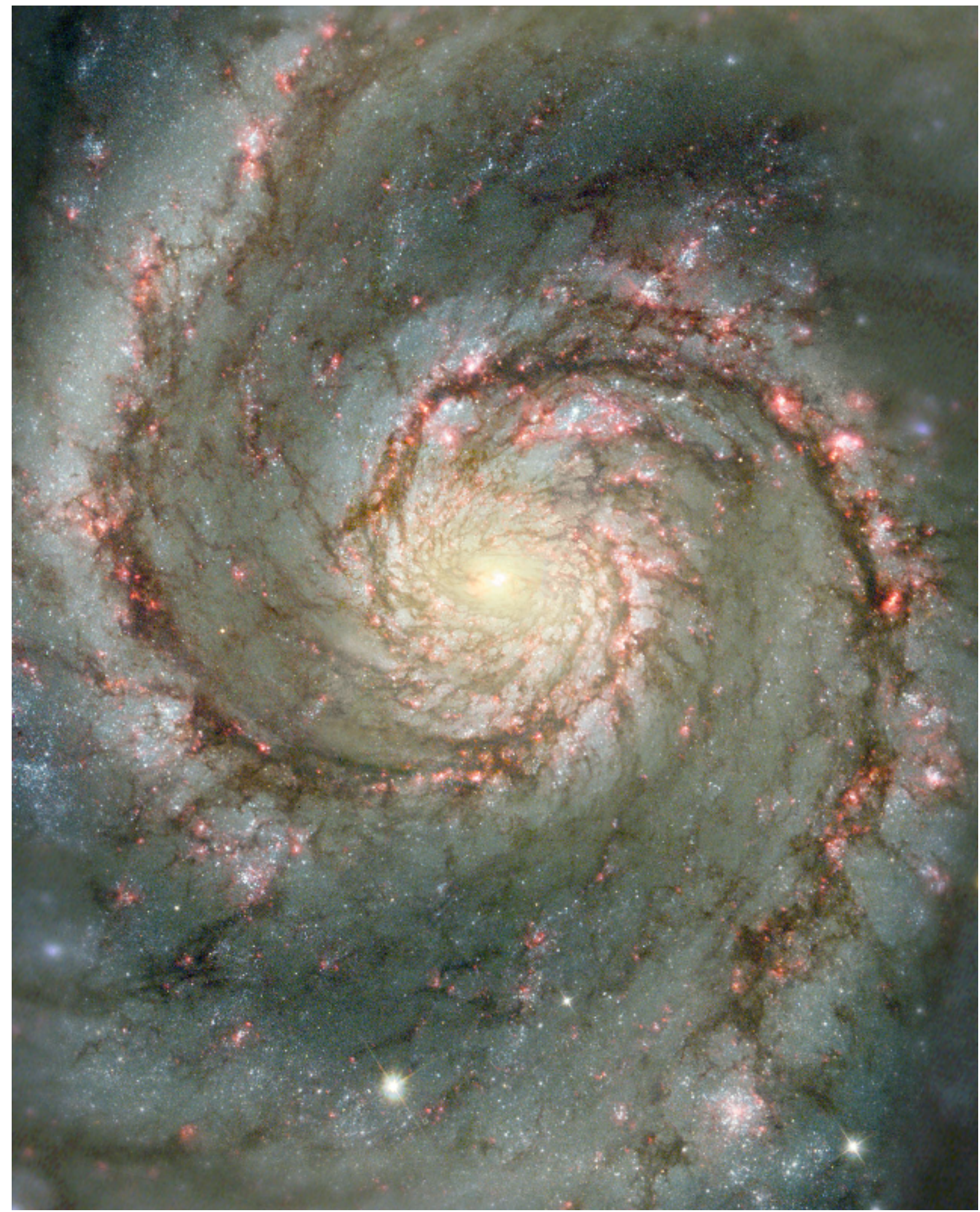

66. http://stapafurdius.wordpress.com/2007/04/11/100-imagens-do-universo-001-a-010/

Briggs destaca que antigamente os cientistas se encantavam com a ordenação mecânica no Universo (1994, p. 54); porém, com a descoberta da teoria 
do Caos e da geometria fractal, a beleza reside nos aspectos flutuantes de uma holística híbrida de simetria e caos. E a geometria fractal permanece a melhor geometria, capaz de aproximar o mundo real de um modelo matemático satisfatório. Ora, a grande revolução de Mandelbrot foi revelar, segundo Briggs, o que todos nós já sabíamos: que a Terra não é uniforme.

Voss apresenta uma tabela com as principais diferenças entre a geometria Euclidiana e a Geometria Fractal. A primeira que ele apresenta é que a Geometria Fractal é uma invenção moderna enquanto a Geometria Euclidiana tem mais de 2000. Enquanto as formas Euclidianas possui algumas poucas característica como tamanho, raio de uma circunferência, lados de um cubo, etc., as formas fractais não possuem tamanhos característicos. Enfim, e é justamente isso que gostaríamos de destacar, a Geometria Euclidiana mais uma vez se mostra inapropriada, dessa vez em relação às formas naturais.

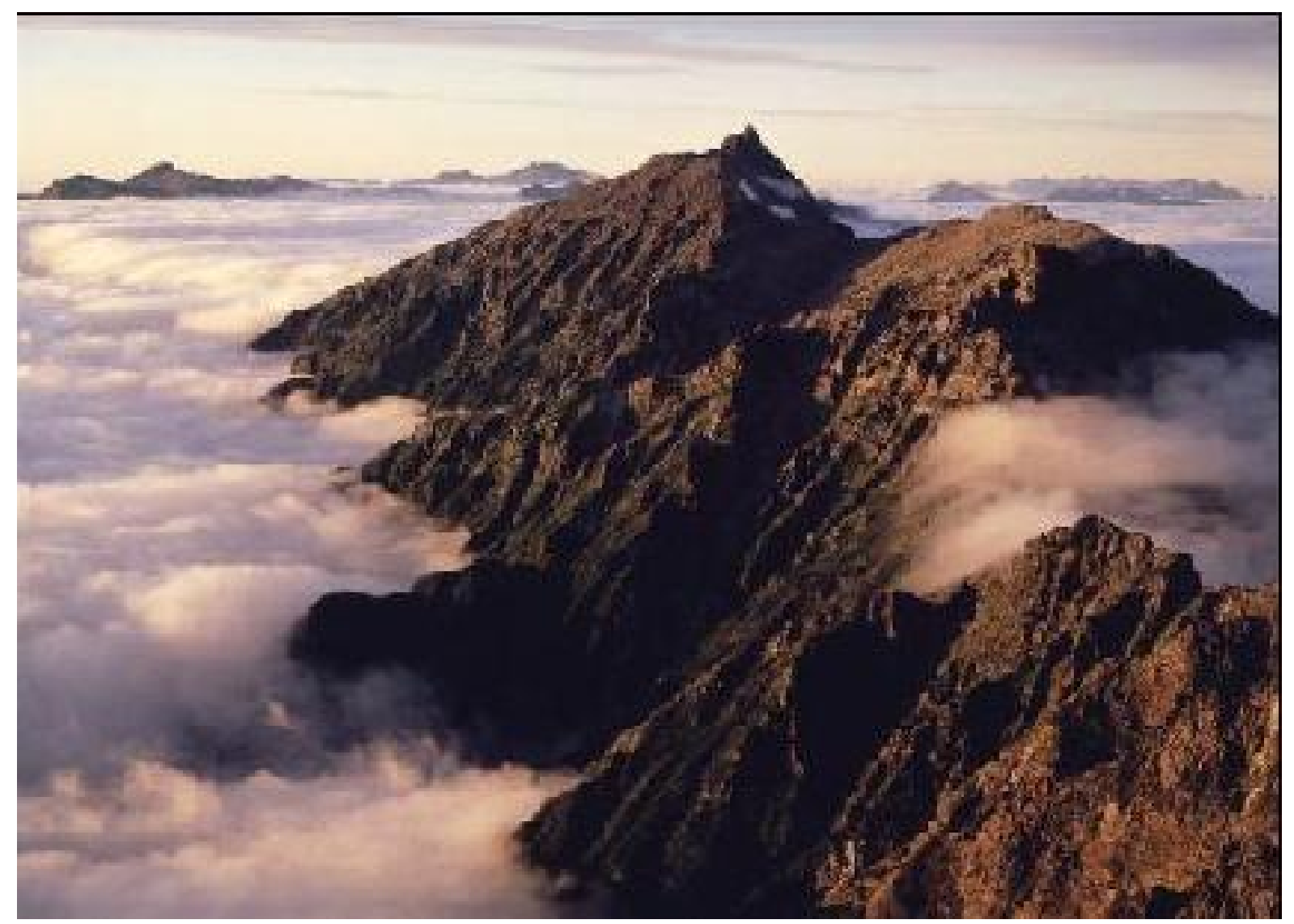

67. http://stapafurdius.wordpress.com/2007/04/11/100-imagens-do-universo-001-a-010/

Então, ao olharmos para uma paisagem, veremos, além da beleza natural que ela traz consigo, veremos também bons exemplos de fractais. E os computadores, 
com sua rapidez para fazer cálculos, permitirá cada, vez mais, a criação de imagens belíssimas a partir de algoritmos. À primeira vista, é difícil acreditar que as figura abaixo foram feitas pro computador. Elas acabam nos remetendo para um cenário futurista, surrealista, chegando, em muitos deles, a lembrando os quadros de Salvador Dali.

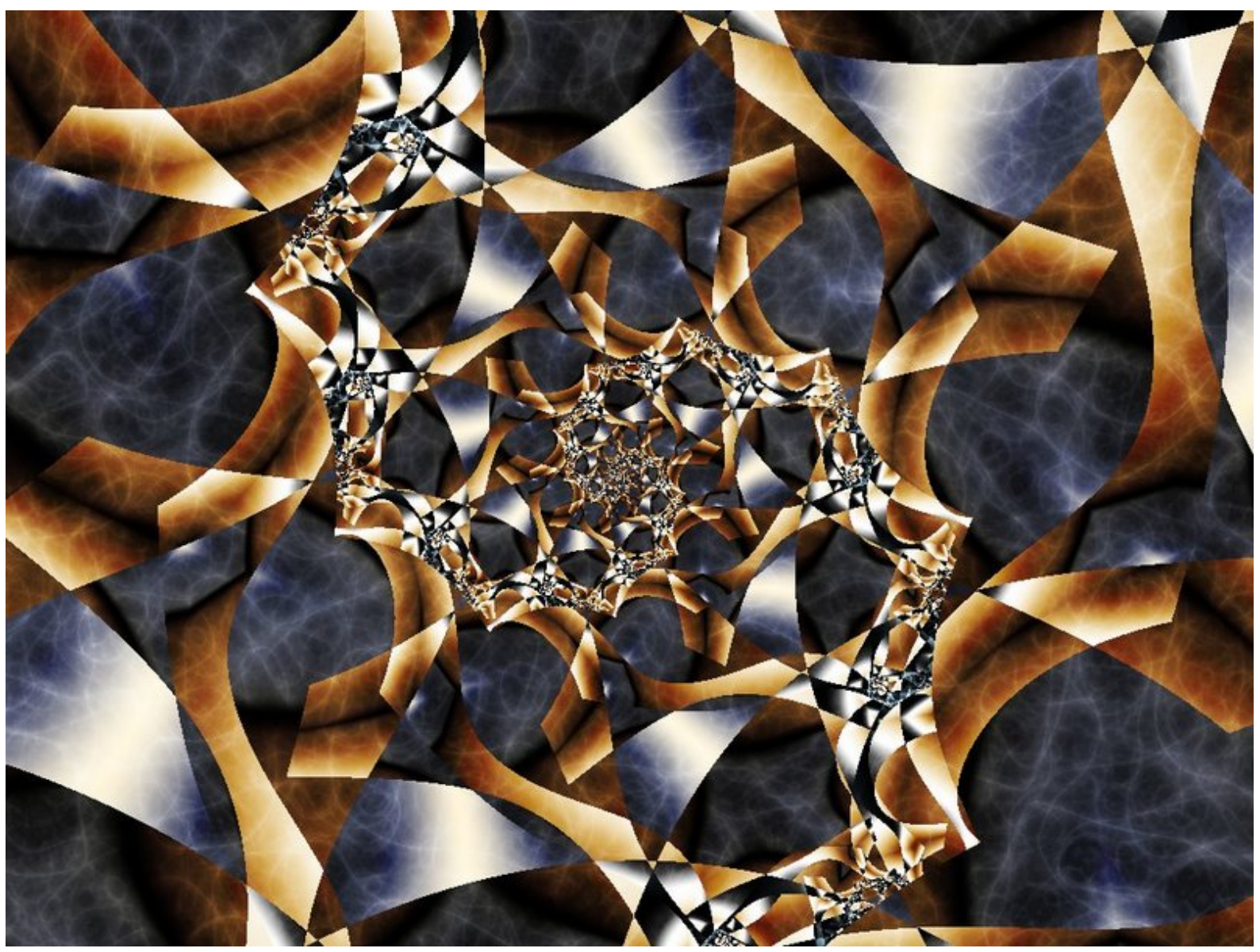

68. Julia aves. http://www.fractarte.com.br/galeria2/galeria.php 


\section{V}

\section{LEITURA DE IMAGEM}

\section{A PARTIR DA GEOMETRIA EUCLIDIANA}

\subsection{Antes da Leitura}

Segundo o roteiro para leitura de imagens contido no Referencial de Expectativas para o Desenvolvimento da Competência Leitora e Escritora no Ciclo II do Ensino Fundamental, devemos, antes da leitura propriamente dita, aquecer o olhar do aluno. Este "aquecimento", no entanto, não deve ser entendido como um olhar desinteressado, mas como um momento de envolvimento efetivo que decorre “(...) de uma mediação didática instigante, que desperta o aluno para interagir com um universo visual de formas, linhas, planos, luzes, cores e prepara o terreno para que vivencie uma experiência estética" (Referencial de Artes: 2006, p. 27). Uma vez que leituras visuais podem proporcionar experiências estéticas significativas, levando o aluno a um encantamento, devemos, pois, produzir experiências estéticas em sala de aula. Mas uma mediação didática instigante não surge do "nada"! Então, como proceder?

O Referencial ainda sugere - como uma das estratégias para desenvolver habilidades interpretativas - que os alunos registrem suas primeiras impressões e as leiam em voz alta para o resto da turma. A intenção, com esse tipo de registro, é “(..) tomar conhecimento da primeira reação que uma imagem causa nos alunos para depois confrontá-la com as interpretações e reflexões que emergem de sua leitura, do contato mais prolongado com ela" (Referencial de Artes: 2006, p. 29).

Nesta etapa de desenvolvimento cabe ao professor instigar e despertar a curiosidade dos educandos para que eles possam se entregar ao prazer da fruição. Para tanto, é necessário que o professor partilhe seu conhecimento sem, no entanto, desprezar as referências trazidas pelos alunos. Desta maneira, professor criaria um ambiente favorável, atrativo ao desenvolvimento da leitura propriamente dito. Sendo assim, logo que a imagem for projetada - no nosso caso específico utilizaremos 
seqüência de eslaides e o data show - os alunos poderiam registrar suas impressões individualmente em um caderno, deixando fluir o pensamento; em seguida, o professor poderia registrar algumas dessas impressões para uso coletivo. Mas uma coisa é certa: é extremamente importante que todas as impressões sejam registradas para que, futuramente, sirvam de objeto de reflexão.

É interessante observar que ao se propor uma leitura de imagem não se pode, de maneira alguma, impor uma única leitura. Deve-se, ao contrário, criar oportunidades para que o aluno crie seu próprio sentido por meio da leitura, ou seja, suas experiências devem ser acolhidas e valorizadas. "Portanto, acolher e valorizar os referenciais e conhecimentos de cada aluno é fundamental para a construção de um saber artístico que se torne significativo no desenvolvimento desse sujeito: leitor de imagem e leitor de mundo" (Referencial de Artes: 2006, p. 31).

Como a idéia de "leitura" está associada a textos, seria uma boa oportunidade mostrar que uma pintura também é um texto: um texto pictórico. Perguntar se eles fazem idéia do gênero da imagem que será trabalhada, já que utilizaremos uma reprodução! Após as várias observações feitas pelos alunos relacionadas ao suporte, seria interessante ressaltarmos que a técnica utilizada pelo artista foi a do afresco, sem, no entanto, especificar tal técnica; deixar que os alunos tentem descobrir, a partir da própria palavra, como é tal técnica.

\subsection{Durante a Leitura}

Durante a leitura o aluno faz a descrição dos elementos que identificar na obra. É tarefa do educador, nesta fase, estimular o aluno a olhar cuidadosamente para a imagem e dizer o que está vendo: se se trata de um figurativismo ou de uma abstração, por exemplo. Poderíamos iniciar com uma análise subjetiva, ou seja, os alunos falariam exclusivamente a partir de suas experiências, sem se preocuparem com termos técnicos; em outras palavras, sem se preocuparem com um estudo aprofundado: como a que escola a obra pertence, por exemplo. Em seguida, o professor voltar-se-ia ao conteúdo, enfatizando, porém, que "conteúdo de uma obra de arte" é tudo aquilo que está representado nela.

$\mathrm{Na}$ verdade, o conteúdo de uma obra de arte pode ser dividido em três categorias: conteúdo objetivo, conteúdo subjetivo e conteúdo formal. O conteúdo 
objetivo é aquilo que serviu de modelo ao artista, é a imagem principal. No caso específico do afresco de Piero della Francesca, o que serviu de modelo para o artista foram várias pessoas. Quando isso acontece, dizemos que o conteúdo objetivo é "pessoas". Já o conteúdo subjetivo seria um título que damos à obra. Trata-se de um título sem muitas pretensões, uma vez que nos baseamos muito mais em nossas experiências pessoais do que em outro dado qualquer. Portanto, a obra de Piero poderia se chamar "o encontro", "o retorno", "a exaltação", etc. E por fim, a análise formal, como a obra foi pintada. Esse tipo de análise, porém, requer um treino visual mais aprofundado, requer mais estudos; logo, não seria prudente exigir dos alunos tal confronto agora, sendo mais interessante completar a análise posteriormente, quando a contextualizarmos.

Para desenvolvermos tais habilidades, é necessário que coloquemos a projeção do afresco que se quer trabalhar, dando tempo suficiente para que os alunos simplesmente olhem. É fundamental que estes verbalizem suas impressões de modo que as observações possam ser partilhadas por todos. "Repita as falas individuais para a classe, confirmando o que cada aluno verbalizou e registrando, depois, seu depoimento. Esse procedimento ajuda o grupo a tecer a rede de compreensão conjunta da leitura que está sendo realizada" (Referência de Artes: 2006, p. 35).

\subsection{Sobre o Ciclo de Arezzo}

A história do Ciclo de Arezzo começa por volta de 1417, quando os Bacci, uma rica família de mercadores aretinos, proprietários da Capela Maior da Igreja de São Francisco de Arezzo, planejaram adornar a capela com um vitral e uma decoração pictórica. Inicialmente, a obra ficou a cargo do pintor florentino Bicci di Lorenzo, um tardio herdeiro do seco estilo gótico florentino, mas a obra foi interrompida, em 1452, com sua morte; de suas mãos, sobre as paredes da capela, restaram somente a decoração de uma pequena abóboda no teto e de dois Doutores da Igreja na entrada. É provável que a partir deste momento Piero della Francesca tenha começado a trabalhar para os Bacci, “(...) revestindo em poucos anos a estrutura gótica da capela com os afrescos mais modernos e perspectivamente medidos que o século XV italiano tenha podido conhecer" (Angelini: 1991, p. 21). Piero della Francesca instituiu uma nova ordem ao substituir 
o romantismo gótico pelo classicismo mediterrâneo. Na realidade, com Piero della Francesca a Idade Média deu lugar ao Renascimento (Focillon: 1991, p. 08).

O tema escolhido por Piero deriva da Legenda Áurea de lacopo da Varazze, do século VIII, que conta a história milagrosa da madeira da Cruz de Cristo. Trata-se de uma lenda de sabor popular, de gosto medieval e rica de motivos narrativos. Angelini acredita que essas características exerceram grande influência nos séculos XIV e XV, inspirando vários ciclos de afrescos das igrejas da ordem dos franciscanos. Segundo Angelini, os precedentes iconográficos mais conhecidos de Piero eram os afrescos realizados por Agnolo Gaddi para os franciscanos da igreja da Santa Cruz de Florença, os de Cenni di Francesco para a igreja de São Francisco de Volerra e as posteriores Histórias da Cruz pintada por Massolino em São Augustinho de Empoli, em 1424. Ao que tudo indica, o tema parece ter sido sugerido pelos franciscanos, não só a Piero della Francesca como anteriormente a Bicci di Lorenzo, pois se trata de um tema tradicional entre os franciscanos aretinos.

\subsection{A Historia da Santa Cruz}

Segundo a síntese de Angelini, a história narra como Adão, prestes a morrer, mandou seu filho Set ver o arcanjo Miguel, que lhe entregaria algumas sementes da árvore do pecado para que ele as colocasse na boca do pai no momento da agonia. A árvore, então, cresceu sobre a tumba do patriarca, foi derrubada pelo rei Salomão e sua madeira serviu de ponte. A rainha de Saba, em viagem para visitar o rei Salomão e conhecer sua sabedoria, estava prestes a cruzar a ponte quando, por milagre inteirou-se de que naquela madeira seria crucificado o Salvador. A rainha, então, prostou-se devotamente em sinal de adoração. Salomão, ao saber da mensagem celeste recebida pela rainha, acorreu a desfazer a ponte e enterrar a madeira que causaria o fim do reino dos hebreus. Não obstante os esforços do rei Salomão, a madeira foi encontrada e, segundo o presságio, é transformada em instrumento da Paixão.

Três séculos mais tarde, o imperador Constantino, às vésperas da batalha da Ponte Mílvio contra Maxêncio, recebeu em sonho uma mensagem divina, que o incitou a colocar-se sob o signo da Cruz para superar o inimigo. Após a vitória de Constantino, Elena, sua mãe, dirigiu-se a Jerusalém a fim de recuperar a madeira milagrosa. A única pessoa que sabia de seu paradeiro era um hebreu de nome 
Judas, que se recusava terminantemente a revelar o segredo, e por isso foi torturado dentro de um poço. Obrigado a confessar, o judeu indicou um templo de Vênus como o local onde estavam escondidas as três cruzes do calvário. Destruído o templo, a imperadora desenterrou as três relíquias e a verdadeira cruz foi reconhecida, porque ao contato com ela um jovem ressuscitou milagrosamente.

No ano de 615, o rei persa Cosroes roubou a madeira para adorá-la juntamente com outros artefatos idólatras. Heráclito, então imperador do Oriente, atacou o rei persa e, após vencê-lo, decidiu levar a Santa Cruz a Jerusalém. Por intervenção de uma força divina, Heráclito foi impedido de entrar triunfalmente em Jerusalém. Decidiu, pois, despir-se de toda pompa e, assim, conseguiu entrar na cidade levantando a Cruz, em sinal de humildade, segundo o exemplo de Cristo. 


\section{Seqüência do Ciclo de Afresco da Capela Maior}

\section{De São Francisco em Arezzo}

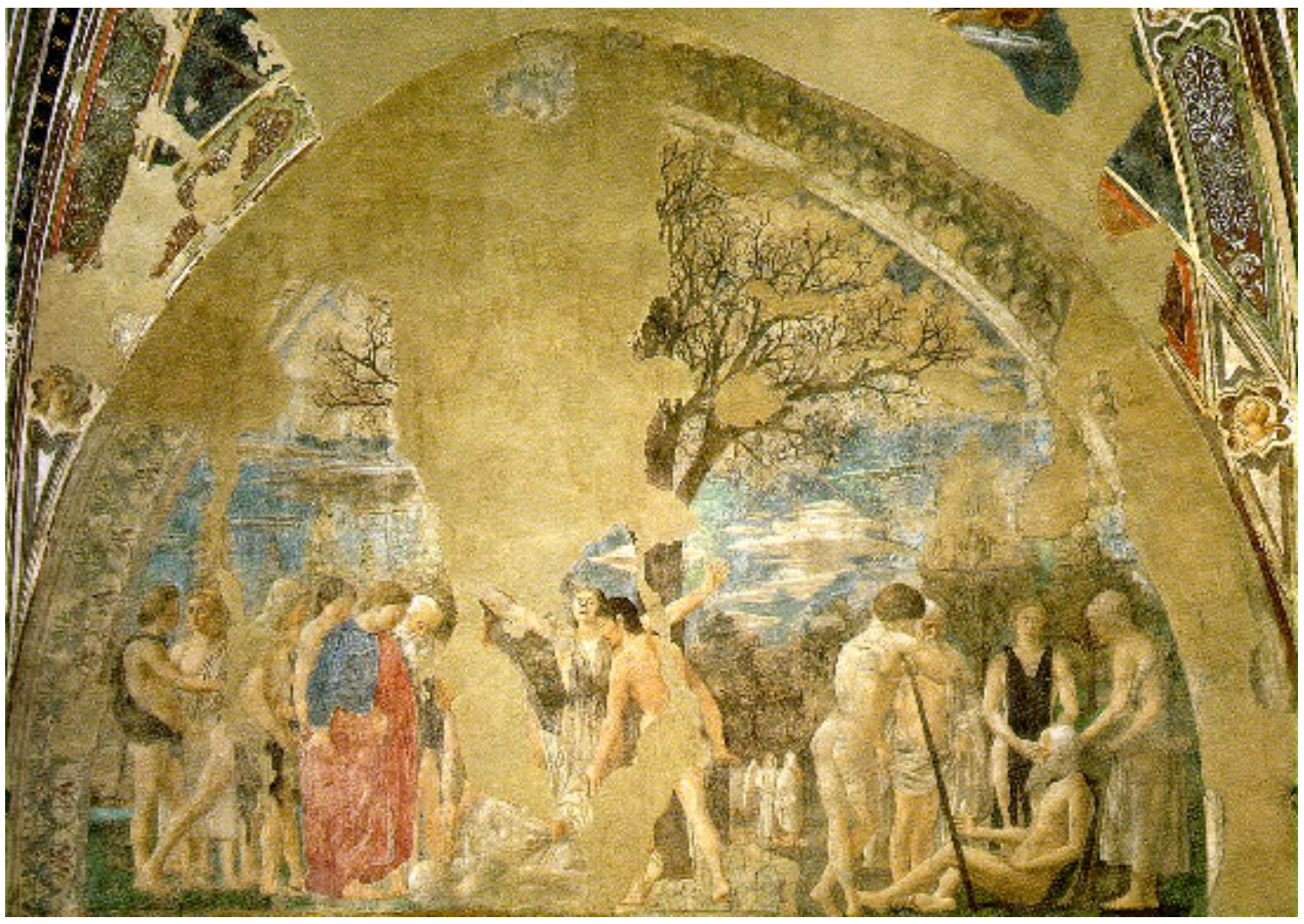

69. Piero della Francesca (c. de 1412-1492). A Morte de Adão. Sobre a História da Santa Cruz, São Francisco, Arezzo.

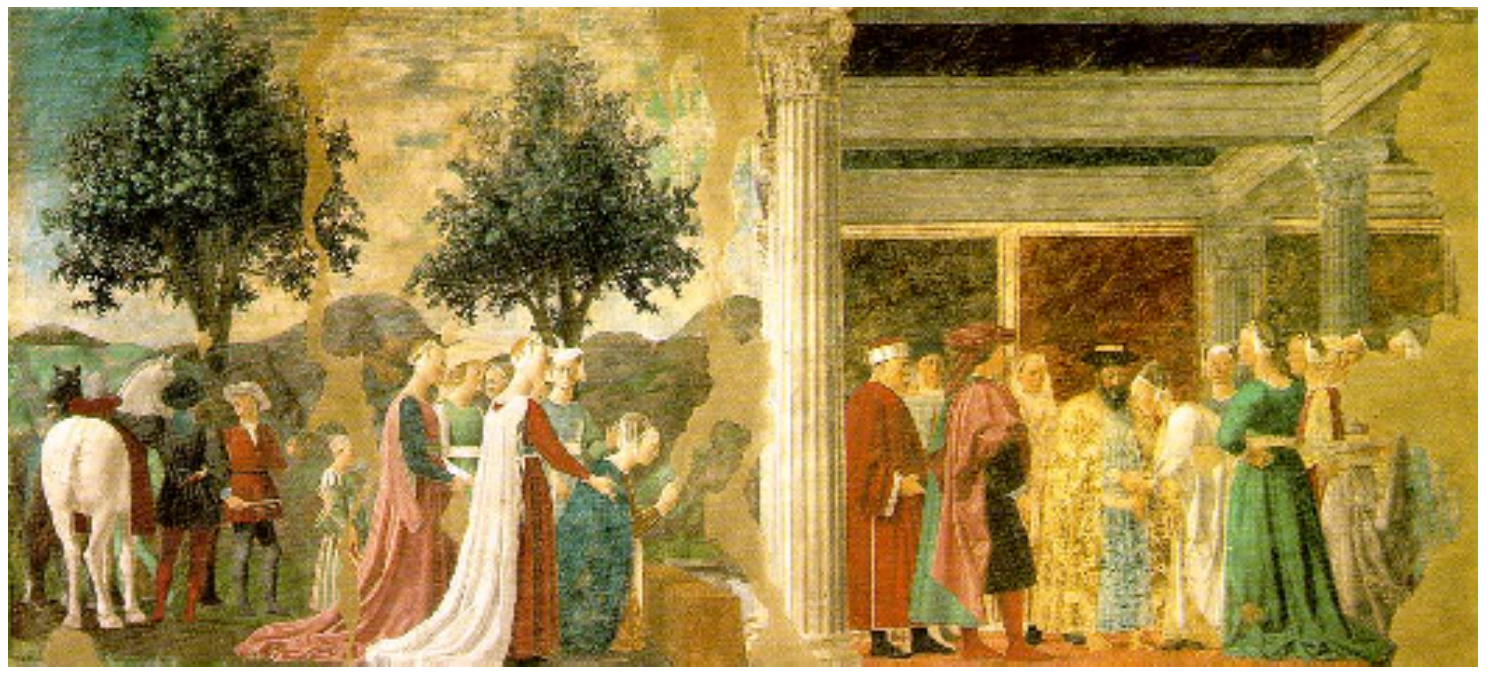

70. Piero della Francesca (c. 1412-1492). A Rainha de Sabá reconhece a Madeira e Encontro de Salomão com a Rainha de Sabá. Sobre a História da Santa Cruz, São Francisco, Arezo. 


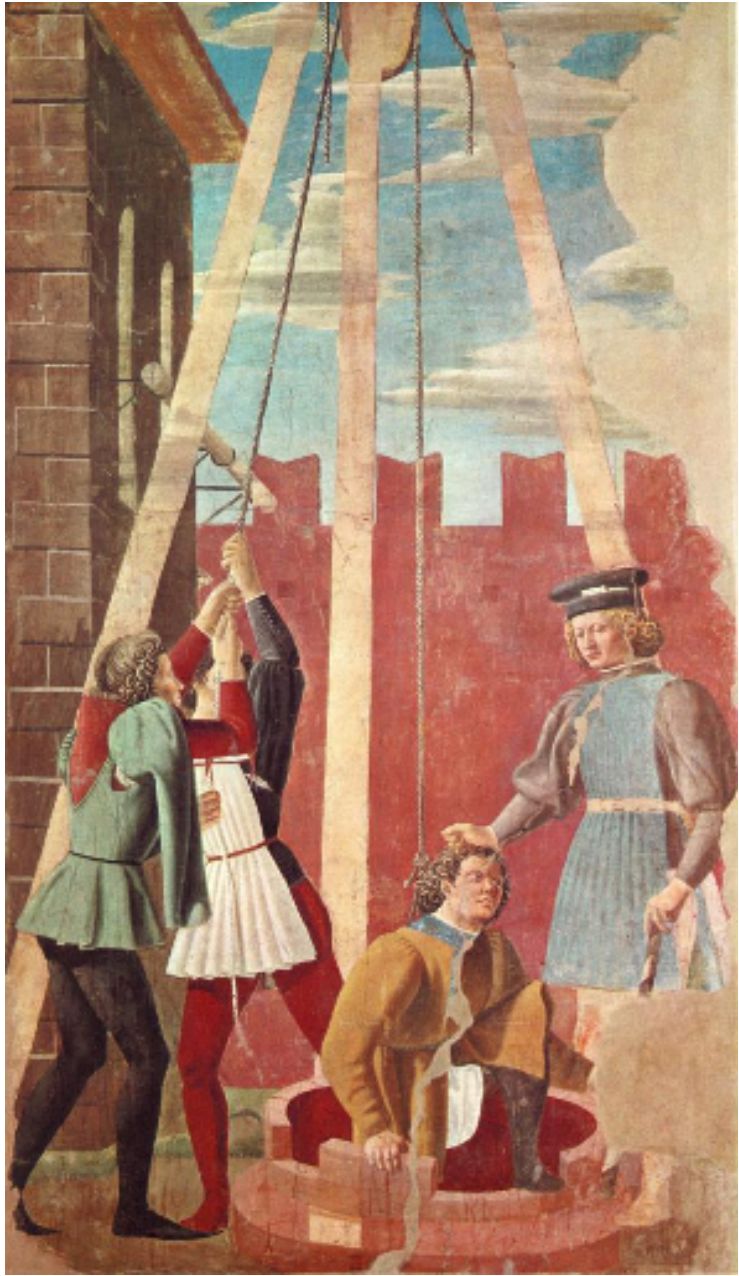

71. Piero della Francesca (c. 1412-1492). $A$ Tortura do Judeu. Sobre a História da Santa Cruz, São Francisco, Arezzo.

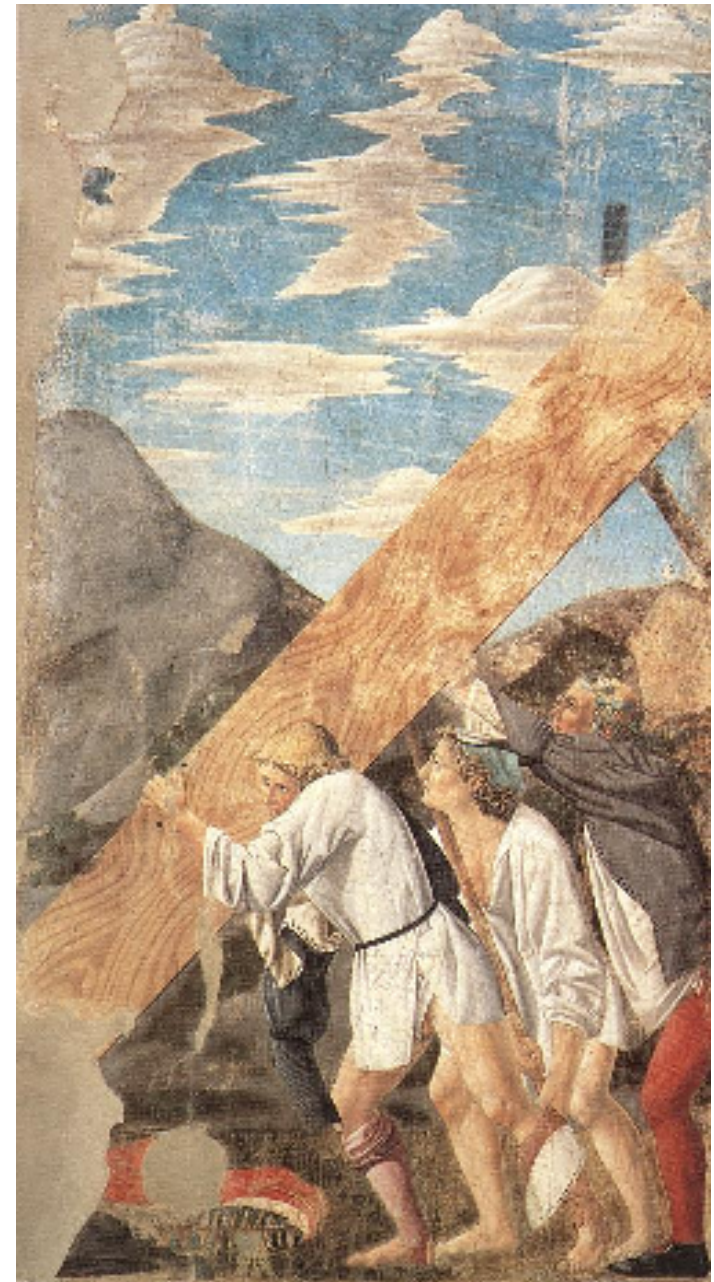

72. Piero della Francesca (c. 1412-1492). $O$ Transporte da Madeira da Cruz. Sobre a História da Santa Cruz, São Francisco, Arezo.

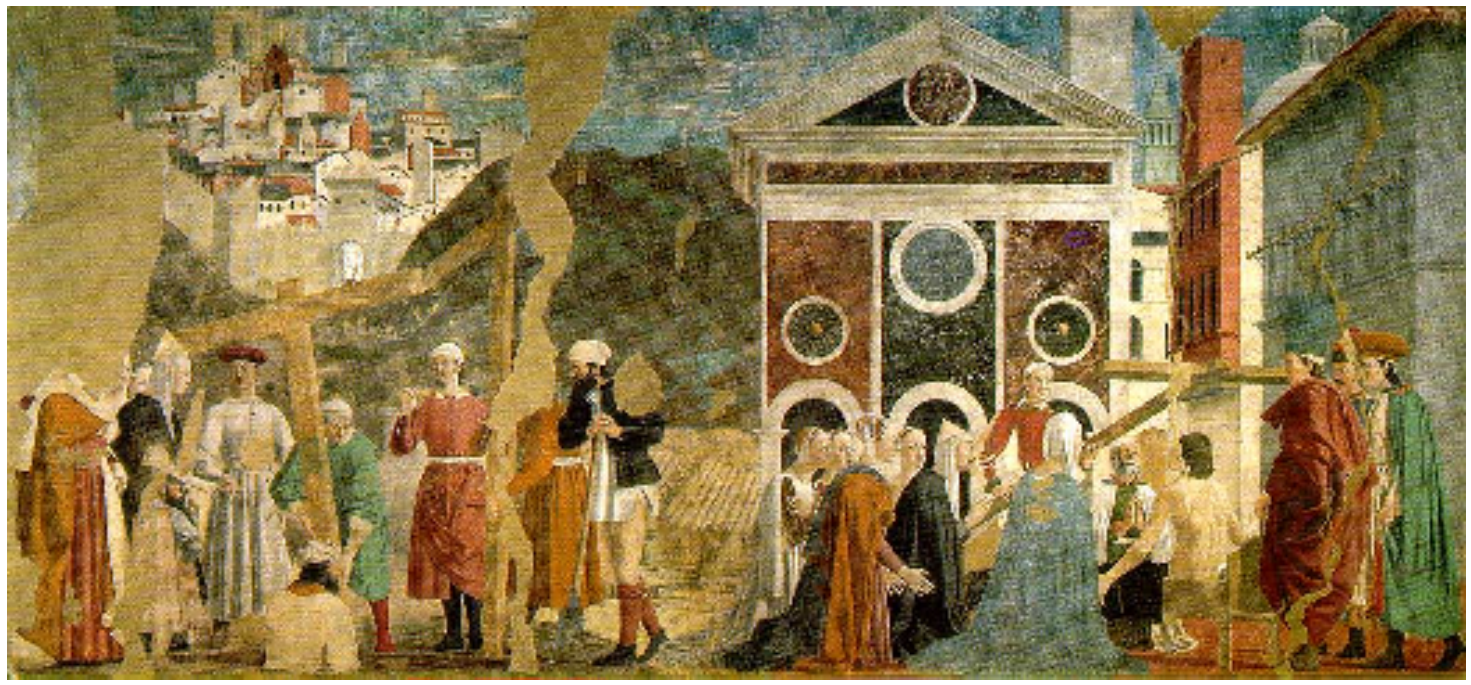

73. Piero della Francesca (c. 1412-1492). Descoberta e Prova da Verdadeira Cruz. Sobre a História da Santa Cruz, São Francisco, Arezzo. 


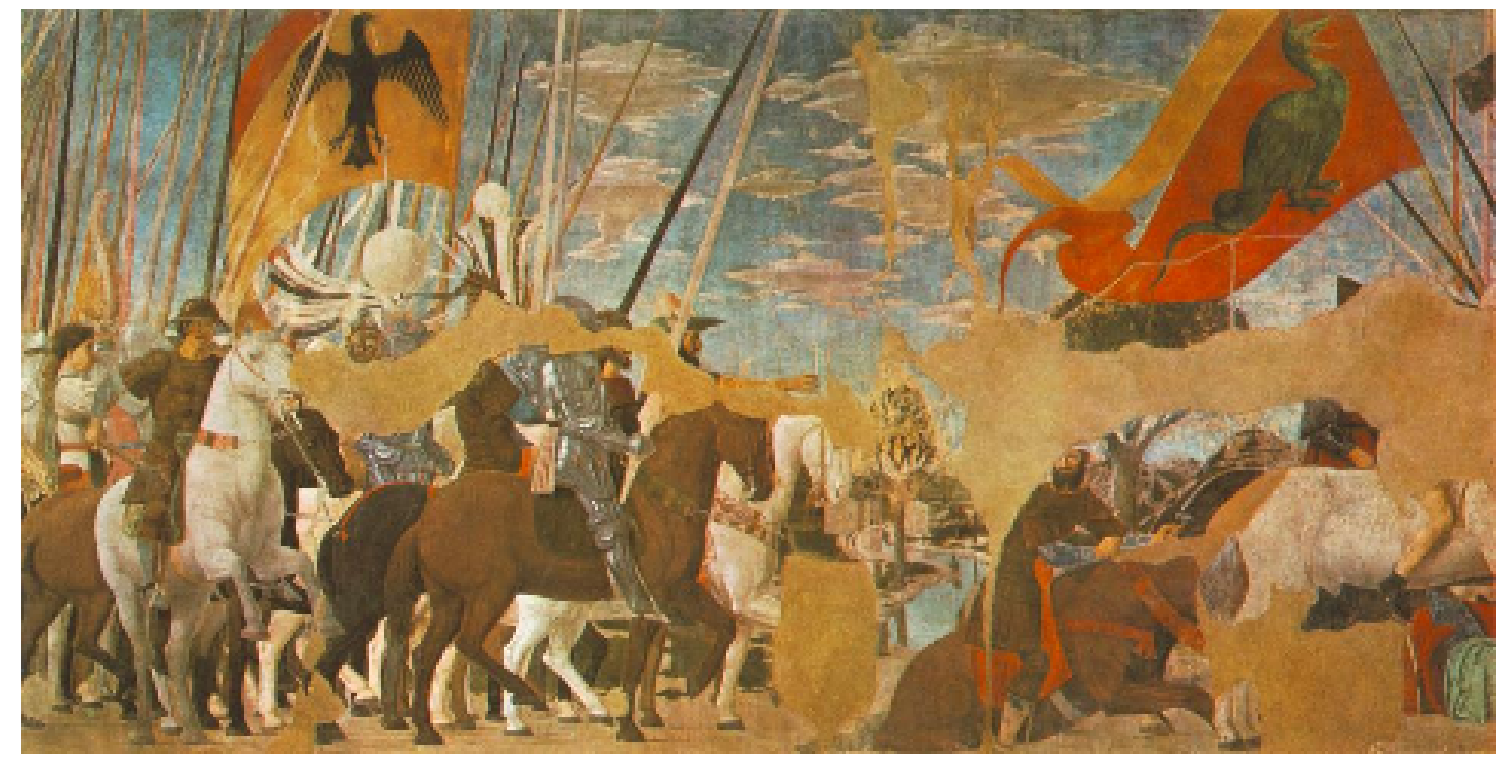

74. 1. Piero della Francesca (c. de 1412-1492). Batalha de Constantino contra Maxêncio. Sobre a Hstória da Santa Cruz, São Francisco Arezzo. 


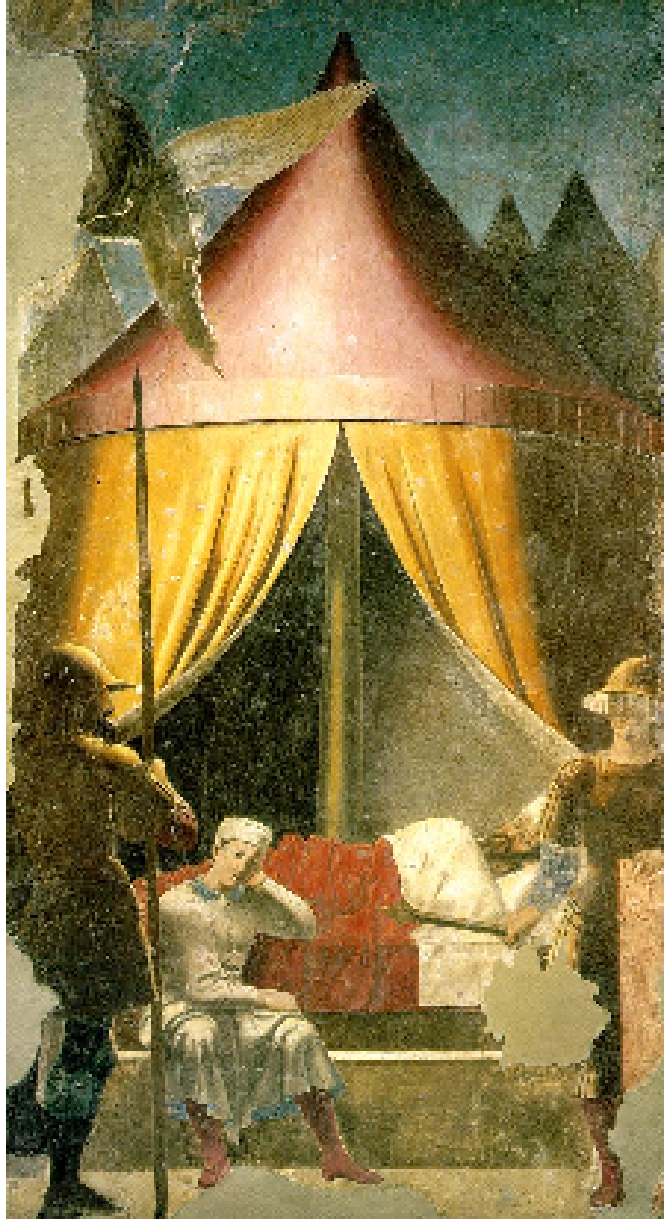

75. Piero della Francesca (c. de 1412-1492). Sonho de Constantino. Sobre a História da Santa Cruz, São Francisco, Arezzo.

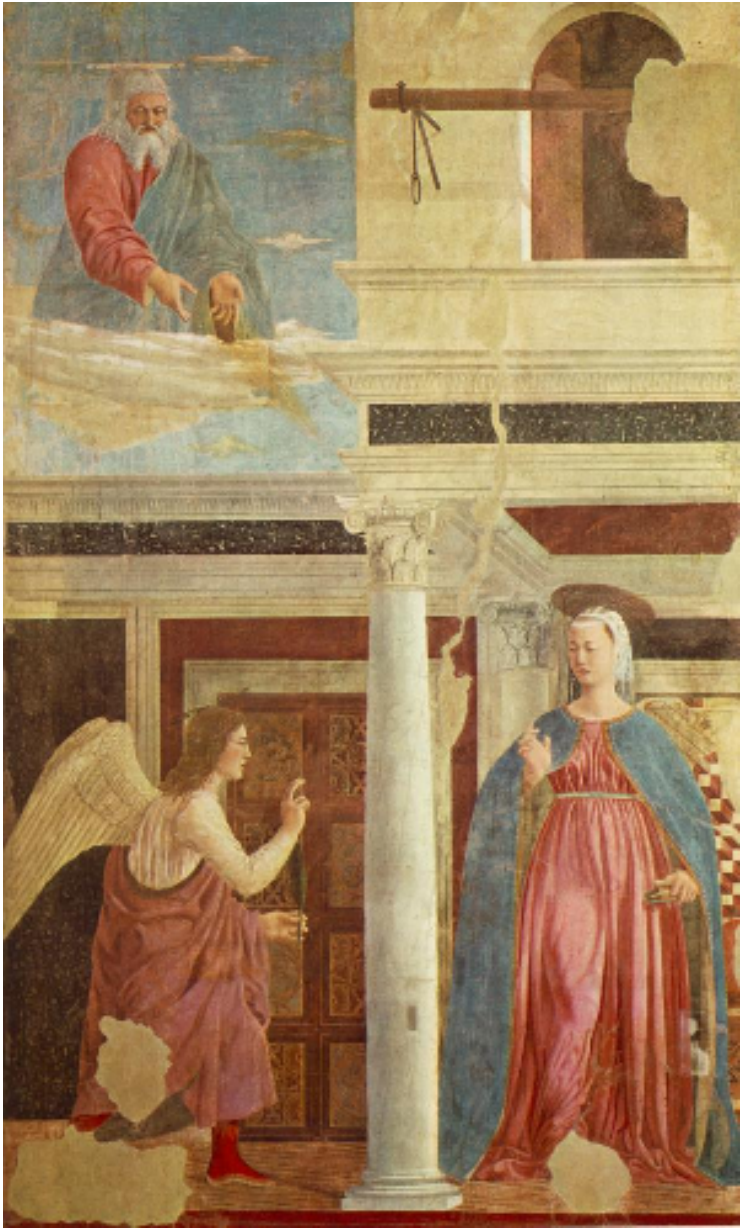

76. Piero della Francesca (c. de 1412-1492). $A$ Anunciação. Sobre a História da Santa Cruz, São Francisco, Arezzo. 


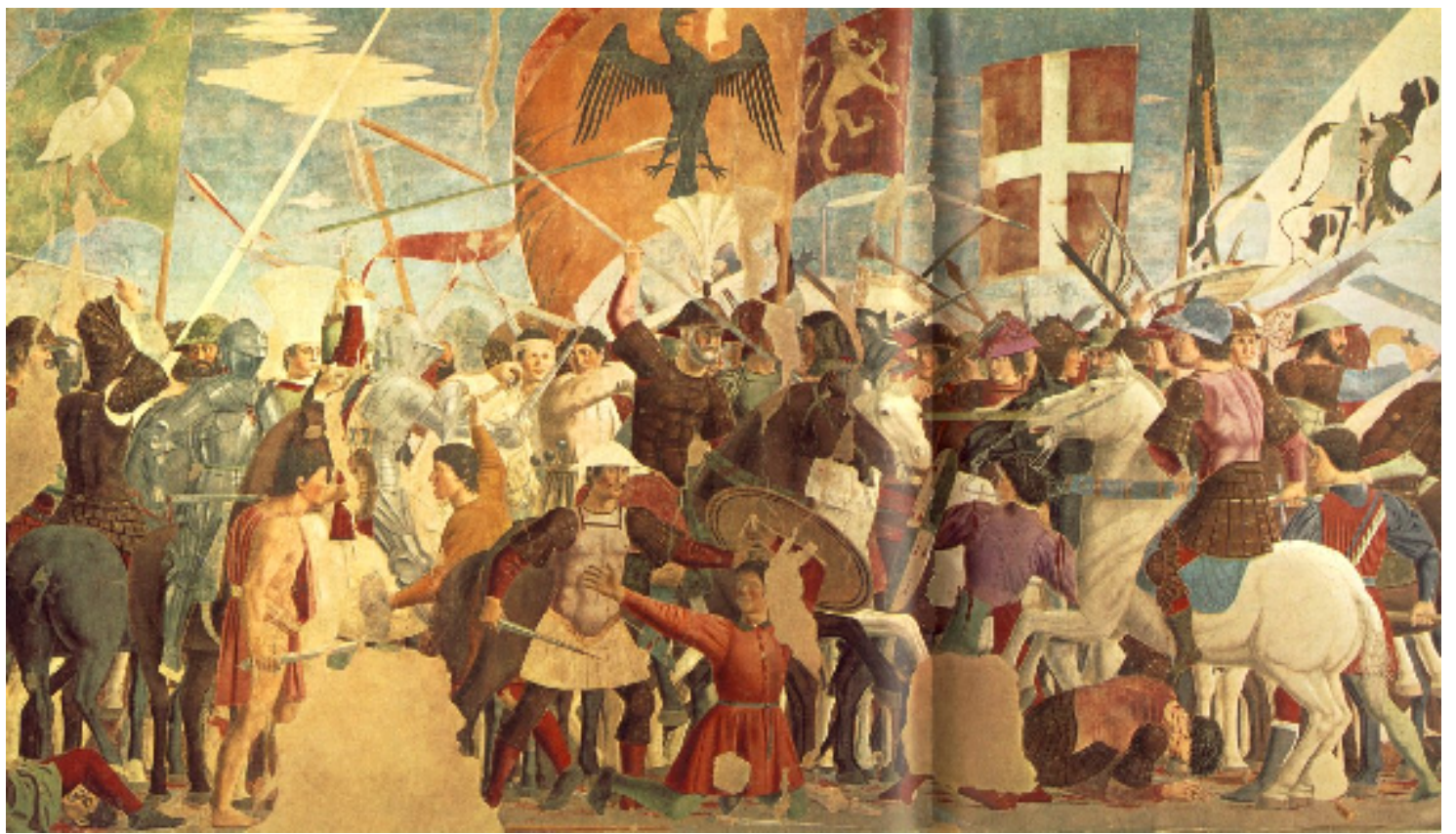

77. Piero della Francesca (c. 1412-1492). Batalha de Heráclio contra Crosroé. Sobre a História da Verdadeira Cruz, São Francisco, Arezzo.

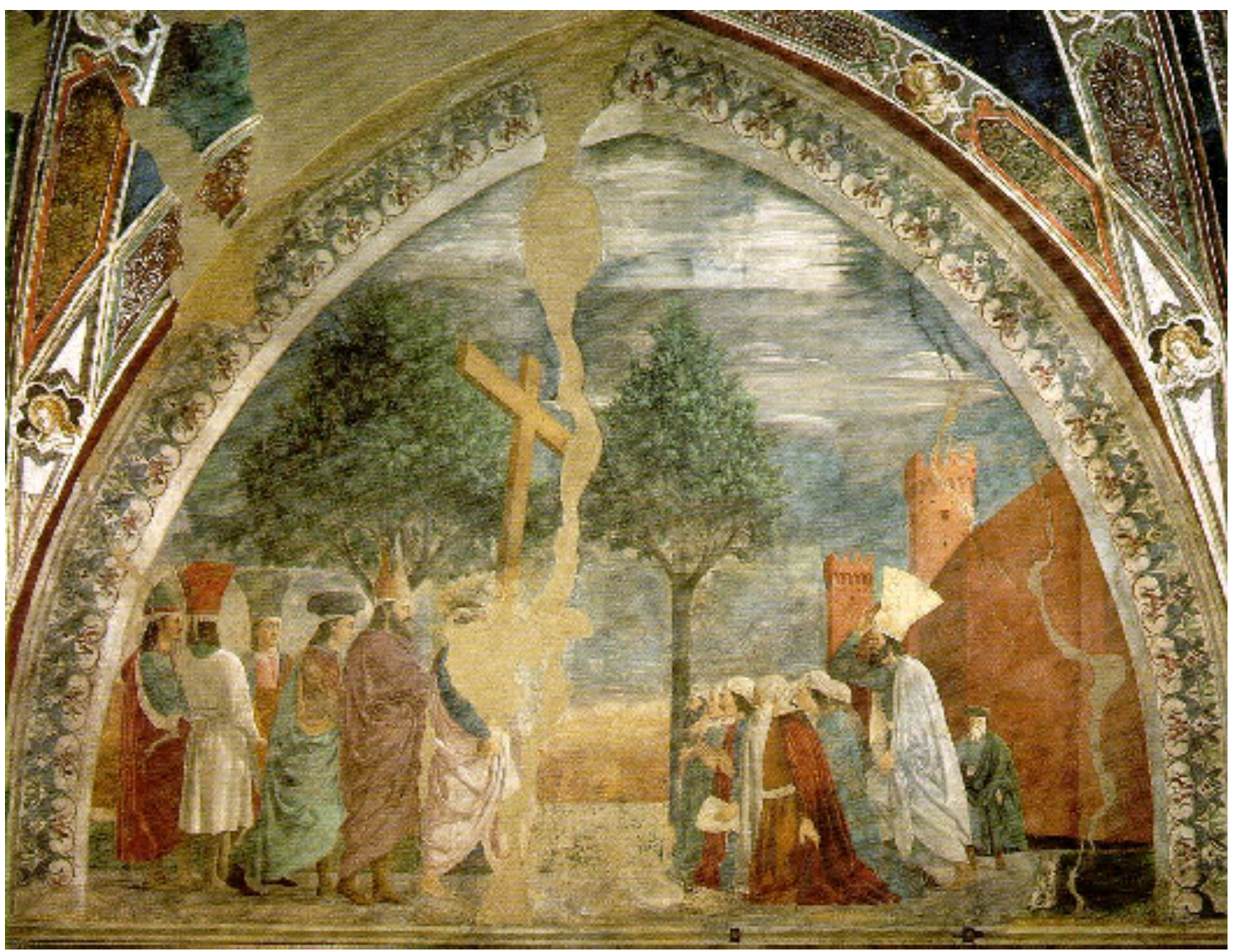

78. Piero della Francesca (c. de 1412-1492). Exaltação da Cruz-Heráclio que Leva a Verdadeira Cruz a Jerusalém. Sobre a História da Verdadeira Cruz, São Francisco, Arezzo. 


\subsection{Análise}

Analisar uma obra de arte é tentar desvendar o processo criador do artista, ou seja, é investigar como o artista trabalhou com os elementos da composição, seus aspectos formais e estruturais: linhas, formas, cores, planos, equilíbrio, movimento, temática. Como sugere o Referencial, esta etapa é propícia para que sejam introduzidos "alguns conceitos relativos à estrutura formal da imagem e ampliar o repertório do aluno para os adjetivos que auxiliam a caracterizar esses elementos" (Referencial: 2006, p. 36).

Observar se a composição é abstrata ou figurativa; se o espaço é bidimensional ou tridimensional; o que está em primeiro, em segundo ou em terceiro plano; observar a perspectiva, a simetria, a assimetria; o equilíbrio, as direções, as distâncias; os movimentos; a predominância das linhas; as cores: se são quentes ou frias, claras ou escuras, primárias, secundárias ou terciárias; as texturas: lisas, ásperas, sedosas, aveludadas, porosas, macias, rugosas; as formas: orgânicas, geométricas, arredondadas, triangulares, retangulares, quadradas, cilíndricas, cônicas, piramidais, cheias, vazadas; luminosidade: luz, sombra, claros, escuros; técnicas: pintura, fotografia, desenho, colagem, gravura, escultura, modelagem, tapeçaria; gênero: retrato, paisagem, natureza-morta; estilo: acadêmico, barroco, impressionista, expressionista, abstrato, cubista, surrealista, fauvista, modernista, contemporâneo. Todos esses conceitos ajudarão a caracterizar os elementos formais da linguagem visual.

Dentre os afrescos que compõem o Ciclo de Arezzo, nos propomos a analisar a cena que representa a Exaltação da Santa Cruz, ou seja, o episódio final da Legenda Aurea. Como já foi dito, trata-se da cena em que o imperador Heráclio, após ter recuperado a Santa Cruz, decide leva-la de volta a Jerusalém.

$\mathrm{O}$ afresco está dividido, basicamente, em dois blocos. Do lado esquerdo, segurando a Santa Cruz, está Heráclio, cuja figura, infelizmente, está bastante danificada, acompanhado de seu séqüito: padres gregos e armênios. Do lado direito, ajoelhados, estão, entre as personagens identificadas por Focillon, dois doutores da Igreja: Santo Ambrósio e Santo Agustinho. 


\subsubsection{O Ponto de Fuga}

Traçando um segmento de reta a partir dos dois arcos que se encontram na parte superior da pintura, é possível dividirmos o afresco em duas partes iguais. Teremos, pois, do lado esquerdo um grupo composto de seis pessoas e do lado direito - embora haja mais pessoas compondo o bloco da direita -, podemos contar, também, seis personagens no primeiro plano. Com essa distribuição, percebemos que Piero opta, inicialmente, por um equilíbrio simétrico na obra. Tomando a linha do horizonte como referência - e trançando mais um segmento de reta - o encontro dos dois segmentos nos dá a localização do ponto de fuga da obra. Seguindo, ainda, a linha do muro da cidade (como está demonstrado na figura 02), ela converge justamente para o mesmo lugar, o encontro da linha do horizonte com o segmento de reta que divide a pintura em duas partes iguais.

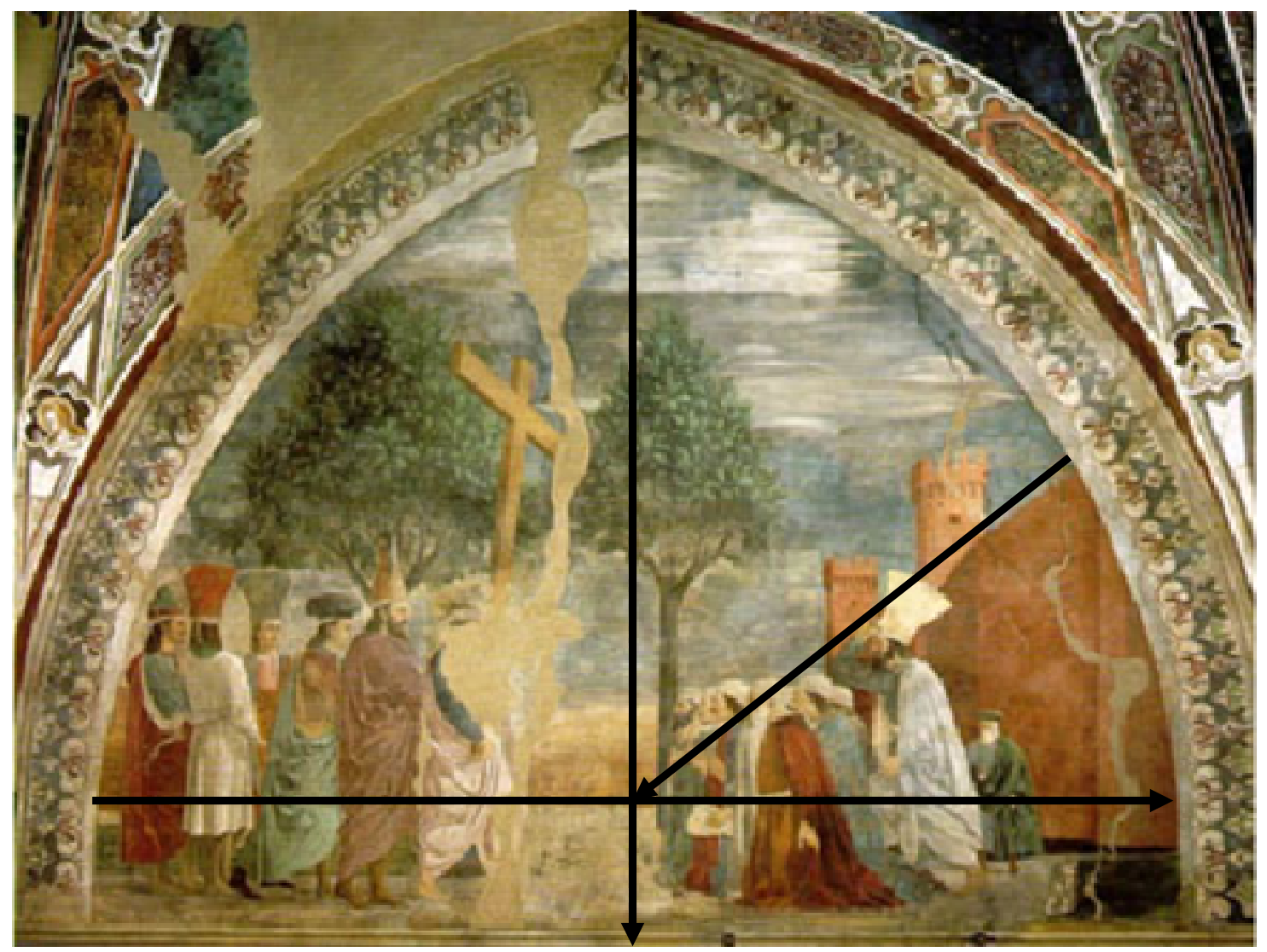

No entanto, para Piero a representação perspectiva não era um elemento primordial na pintura: ele jamais deixou a perspectiva absorver inteiramente a imagem humana. As cenas se desenrolam sempre diante do espaço criado pela 
perspectiva, e jamais dentro desse espaço, ou melhor, a perspectiva se insere entre as personagens de uma multidão, dando, assim, o sentimento de profundidade à massa, sem jamais enformar as figuras. "A razão de tal concepção, que pode parecer estranho em um grande apaixonado pela perspectiva, se compreende facilmente à luz de quaisquer exemplos" (Venturi: 16).

\subsubsection{Proporções e Igualdades}

É possível afirmar que Piero utilizou princípios matemáticos e geométricos ao compor os afresco do Ciclo de Arezzo, para conseguira surpreendente harmonia em suas obras? Há, de fato, uma lógica matemática em relação à proporção e à disposição dos elementos?

Uma proporção, como sabemos, é a igualdade entre duas razões, ou seja, é a igualdade entre duas frações. Toda proporção tem dois extremos e dois meios, e pode ser expressa de várias maneiras, inclusive graficamente. Por exemplo:

$$
\frac{3}{2}=\frac{6}{4}
$$

(Fig. 03)

Uma proporção também pode ser escrita da seguinte maneira:

$$
3: 2:: 6: 4
$$

E, por fim: 

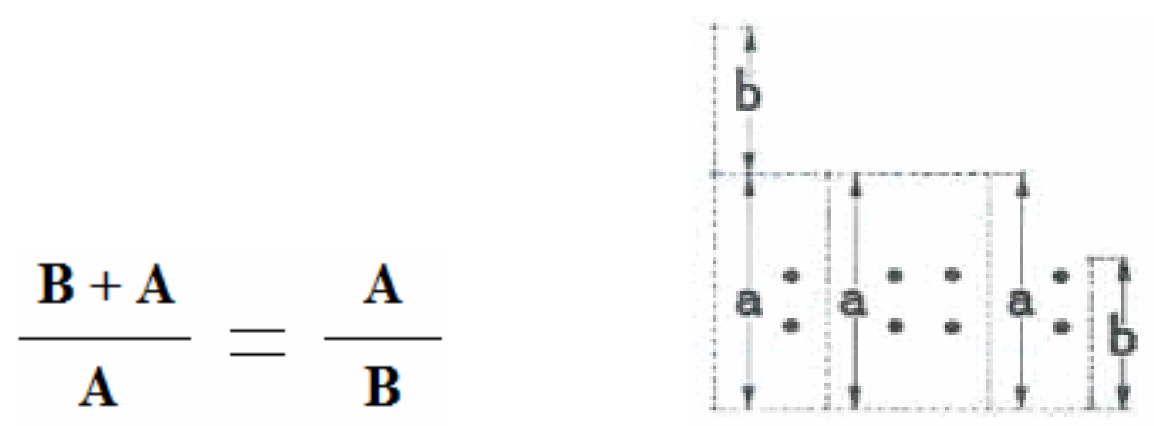

Ora, se aplicarmos os mesmos princípios da representação gráfica acima (a representação da direita) ao afresco de Piero della Francesca, Heráclito que leva a Verdadeira Cruz a Jerusalém, acreditamos que seja possível identificarmos de que maneira ele conseguiu tamanho equilíbrio em sua composição. Então vejamos. Tomemos como base um ponto da parte de cima e a parte de baixo da árvore, até às figuras ajoelhadas; a linha que vai da torre menor até as figuras ajoelhadas; a linha que vai do chapéu da figura que está em pé até a primeira figura ajoelhada à frente; e, por último, a linha que vai do chapéu até os pés da figura menor, à extrema direita da composição. 

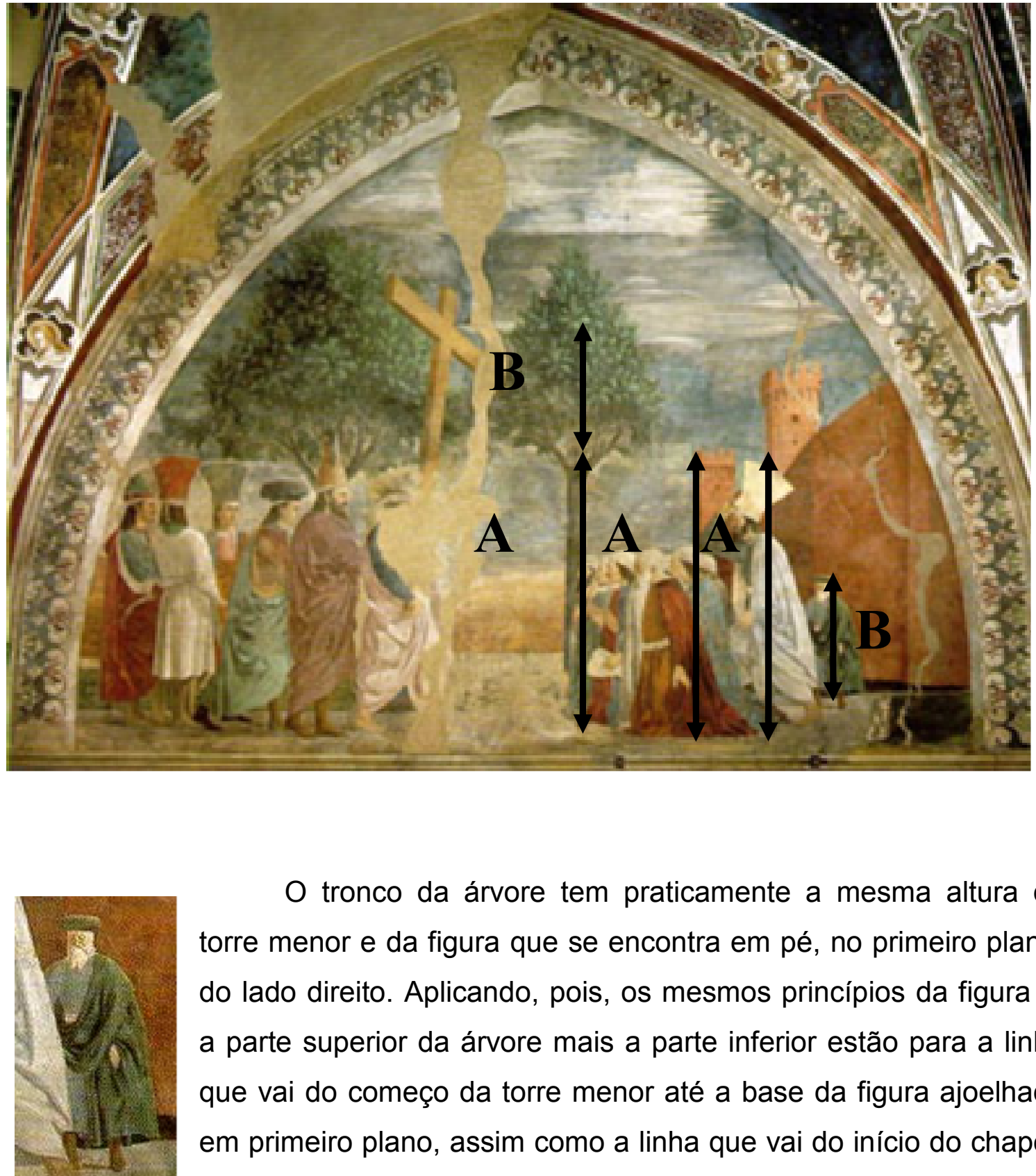

O tronco da árvore tem praticamente a mesma altura da torre menor e da figura que se encontra em pé, no primeiro plano, do lado direito. Aplicando, pois, os mesmos princípios da figura 2, a parte superior da árvore mais a parte inferior estão para a linha que vai do começo da torre menor até a base da figura ajoelhada em primeiro plano, assim como a linha que vai do início do chapéu da figura em pé, até as figuras ajoelhadas, está para a figura menor, à extrema direita. A figura ao lado (fig. 06), aparentemente sem função na narrativa principal, tem, na verdade, um papel relevante no que diz respeito à organização, ao equilíbrio, interno da obra. Isso, acreditamos, nos ajuda a explicar a função dada a esse elemento, uma vez que assume um papel não de destaque -, mas muito importante na composição da obra. 


\subsubsection{Média Proporcional de Dois Segmentos}

Para se conseguir a média proporcional de dois segmentos inicia-se traçando uma linha; sobre ela marcam-se dois segmentos $A B$ e $B C$, um em seguida do outro. Agora divide-se a linha $\mathrm{AC}$ ao meio, determinando, assim, o ponto $\mathrm{O}$. Com centro em $\mathrm{O}$ e raio igual a $A O$ descreve-se uma semi-circunferência. Levanta-se uma perpendicular ao segmento $A C$ pelo ponto $B$. $O$ trecho $B D$, compreendido dentro da semi-circunferência, é a média proporcional entre $A B$ e $B C$.
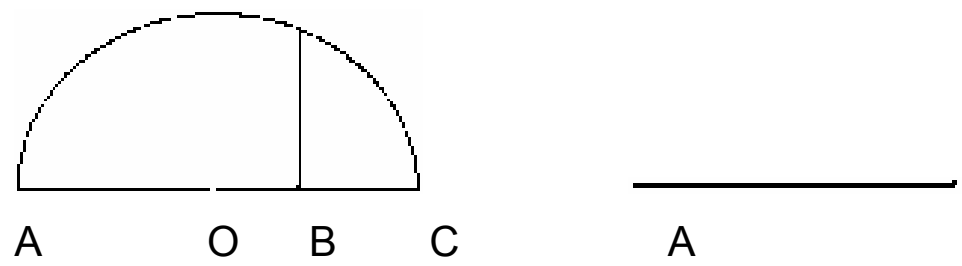

B B

C 


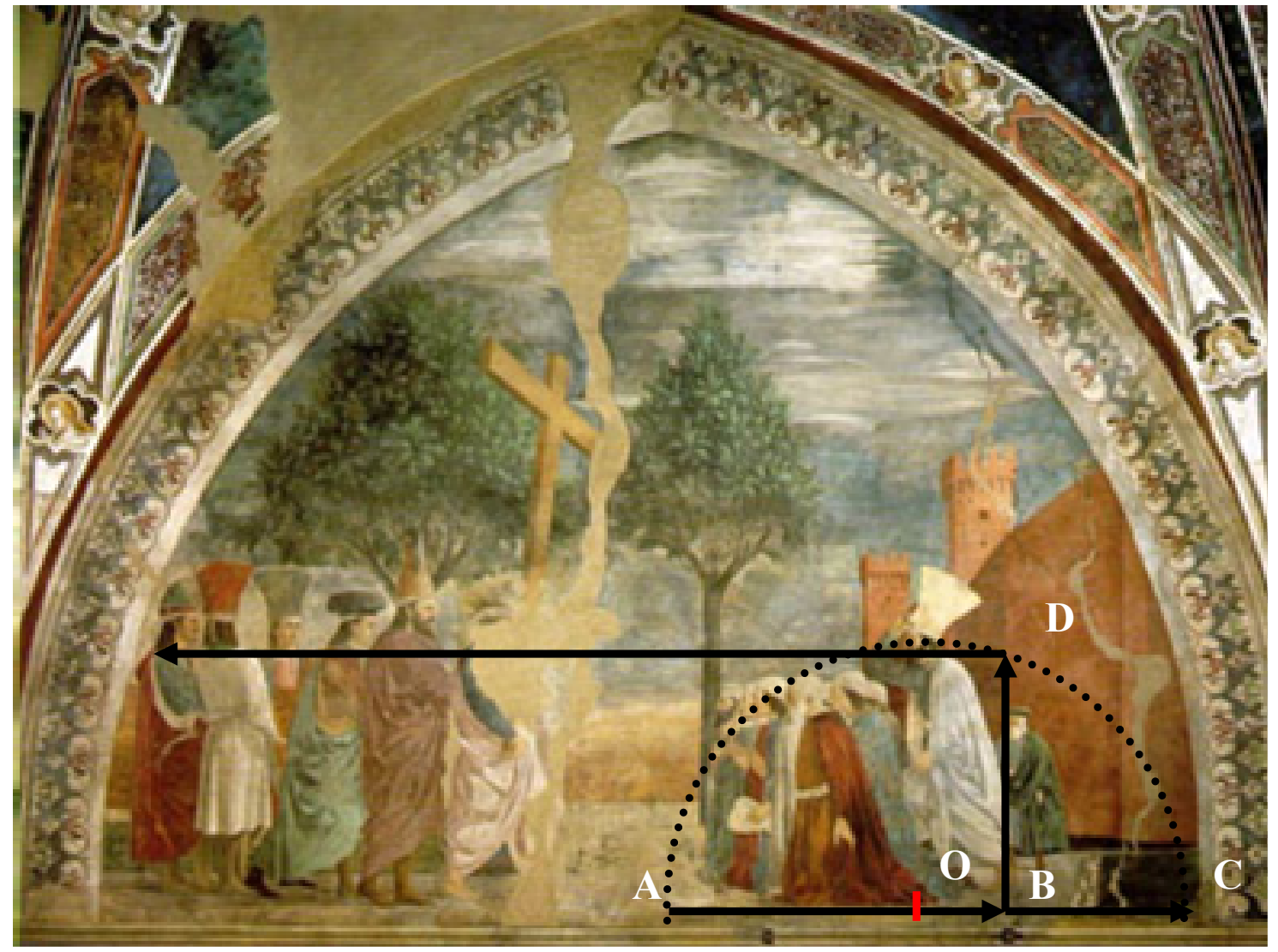

Como podemos notar, o segmento $B D$, que é a média proporcional entre em $A B$ e $B C$, determina o alinhamento das figuras que estão em segundo plano, do lado esquerdo. O interessante é que, à primeira vista, a figura em pé parece estar em primeiro plano; mas na realidade ela também está em segundo plano, ou seja, dialoga com as figuras secundárias do lado direito, pois é a única figura que está em pé.

\subsubsection{Média e Extrema Razão}

A determinação do comprimento de duas partes de um segmento é aquilo que Euclides chamava de divisão de um comprimento em média e extrema razão e que dá origem ao número de ouro $\Phi$ (1.61803398). Trata-se de um número irracional, misterioso e enigmático que surge numa infinidade de elementos da natureza na forma de uma razão. Esta razão recebeu o nome Número de Ouro dos gregos, mais especificamente do escultor grego Phidias.

Seja o segmento AB. Levanta-se uma perpendicular por um de seus extremos $\mathrm{B}$, por exemplo. Marca-se $\mathrm{BO}$ igual à metade de $\mathrm{AB}$. Com centro em $\mathrm{O}$ e raio $\mathrm{OB}$ 
traça-se uma circunferência. Une-se $O$ e $A$. Centro em $A$ e raio em $A Q$, descreve-se um arco que determina o ponto $X$ sobre $A B$. Este ponto divide $A B$ em média e extrema razão.

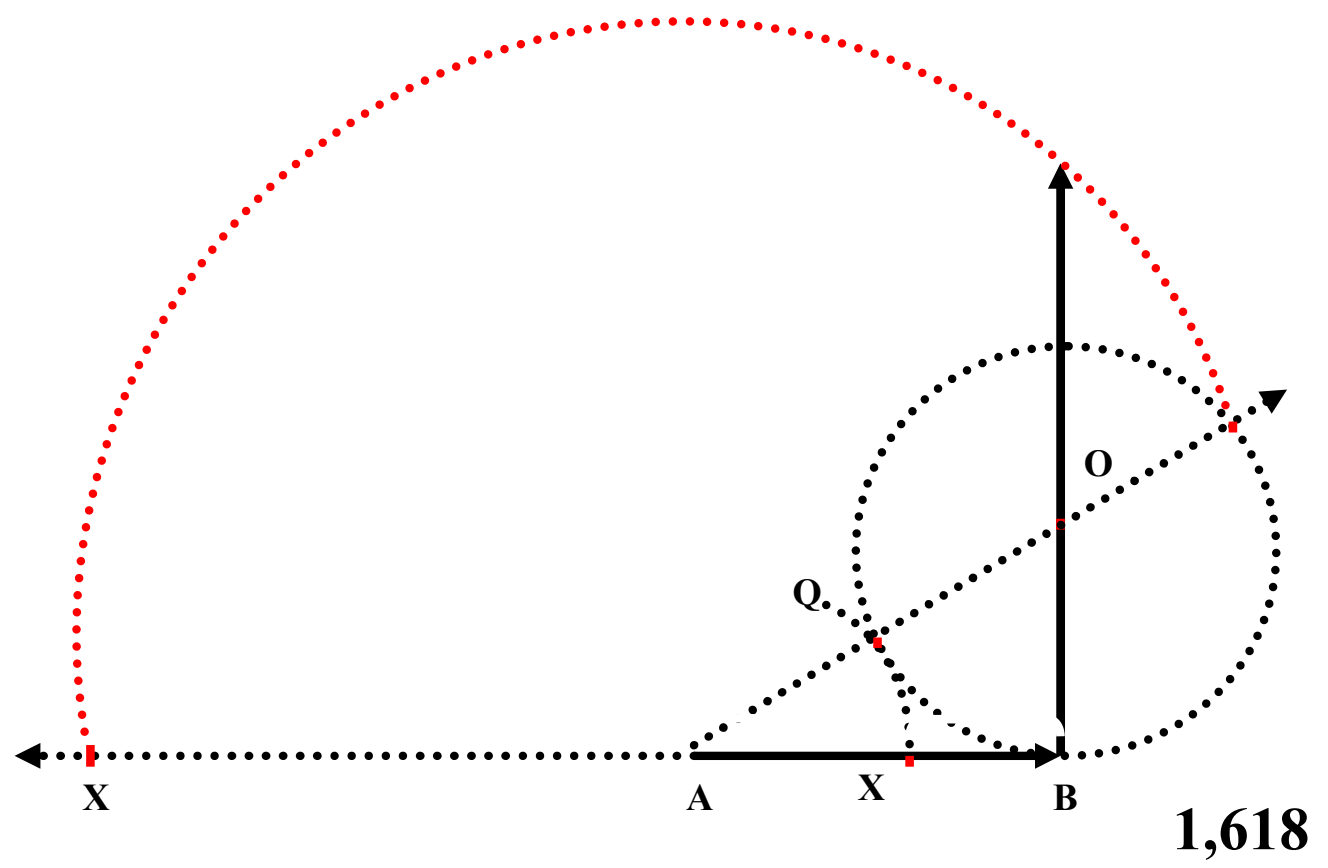




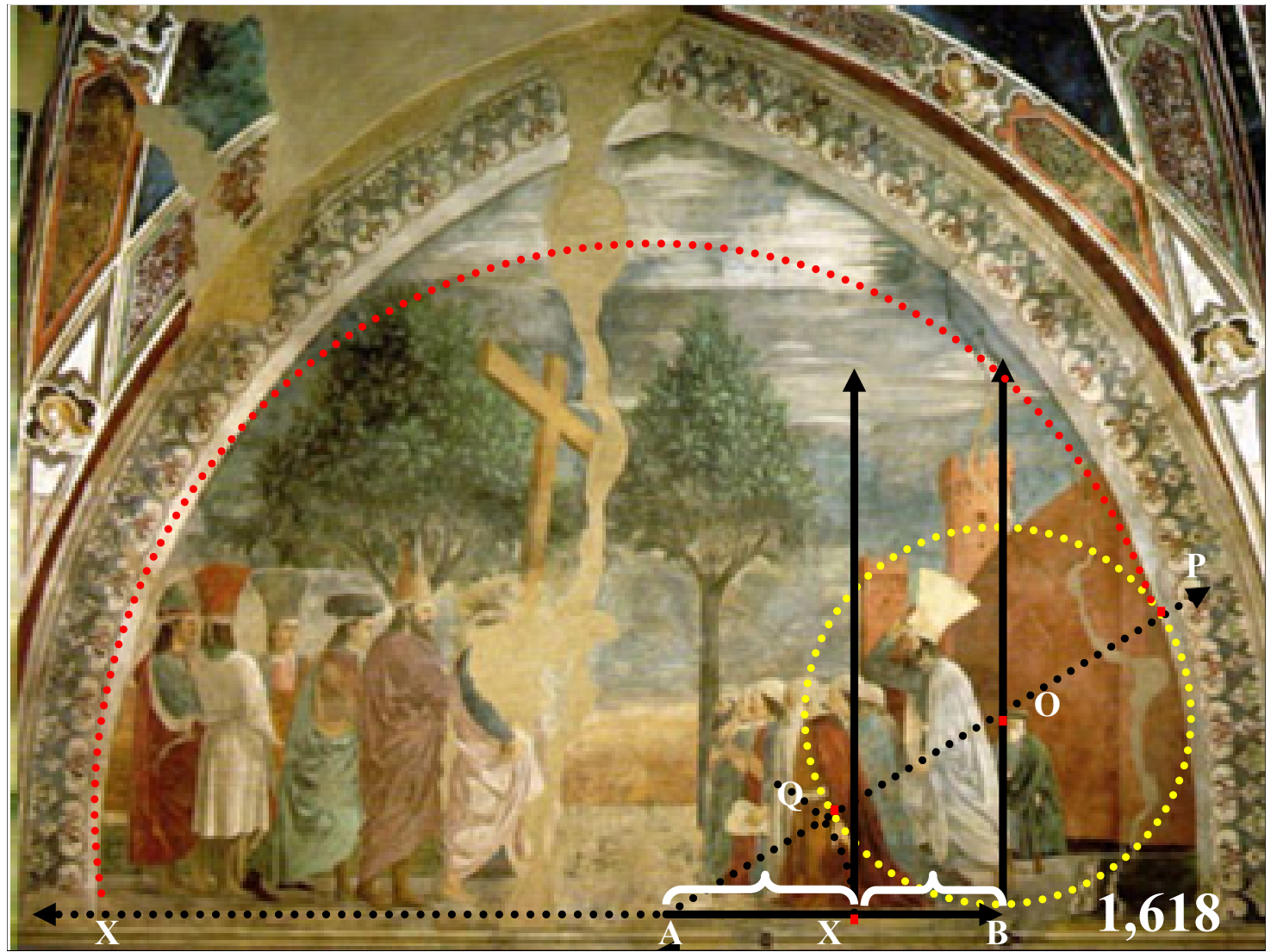

Utilizando a média e extrema razão, é possível verificarmos qual foi o raciocínio que Piero utilizou para organizar o espaço à direita. Então vejamos. Se partirmos da divisão imaginária até a linha que desce da segunda torre teremos, como ponto $\mathrm{X}$, um lugar geométrico que, ao prolongarmos uma reta para cima, coincidirá com o inicio da linha da torre menor. O curioso é que a figura em pé ocupa justamente o mesmo espaço que as duas torres; ou seja, as figuras foram dispostas respeitando o princípio de divisão de um segmento em média e extrema razão.

Abrindo o compasso do ponto $A$ até o ponto $\mathrm{P}$, e descrevendo um arco, termos o ponto X'. O curioso é que esse ponto $X$ ' coincide com o início da área do afresco. A conclusão a que podemos chegar é a seguinte: se Piero não tivesse seguido esse raciocínio, como explicar essa coincidência? 


\subsubsection{Retângulo Áureo}

\section{RETÂNGULO ÁUREO}

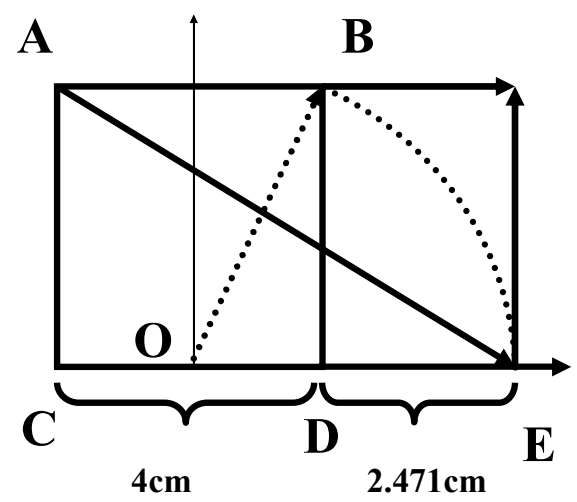

Dado os pontos A, B, C, D, temos um quadrado; determina-se a mediatriz entre CD; prolonga-se $A B$ e CD; centrando o compasso em M (mediatriz), e abrindose até $B$, traçaremos um semi-arco para a direita, conseguindo, assim, o ponto $E$. Ligando o ponto $E$ até o prolongamento de $A B$ teremos um retângulo que, seguindo um dos postulados de Euclides, é formado devido à divisão de uma dada linha reta de maneira que o retângulo contido pelo total e um dos segmentos seja igual ao quadrado do segmento restante. 

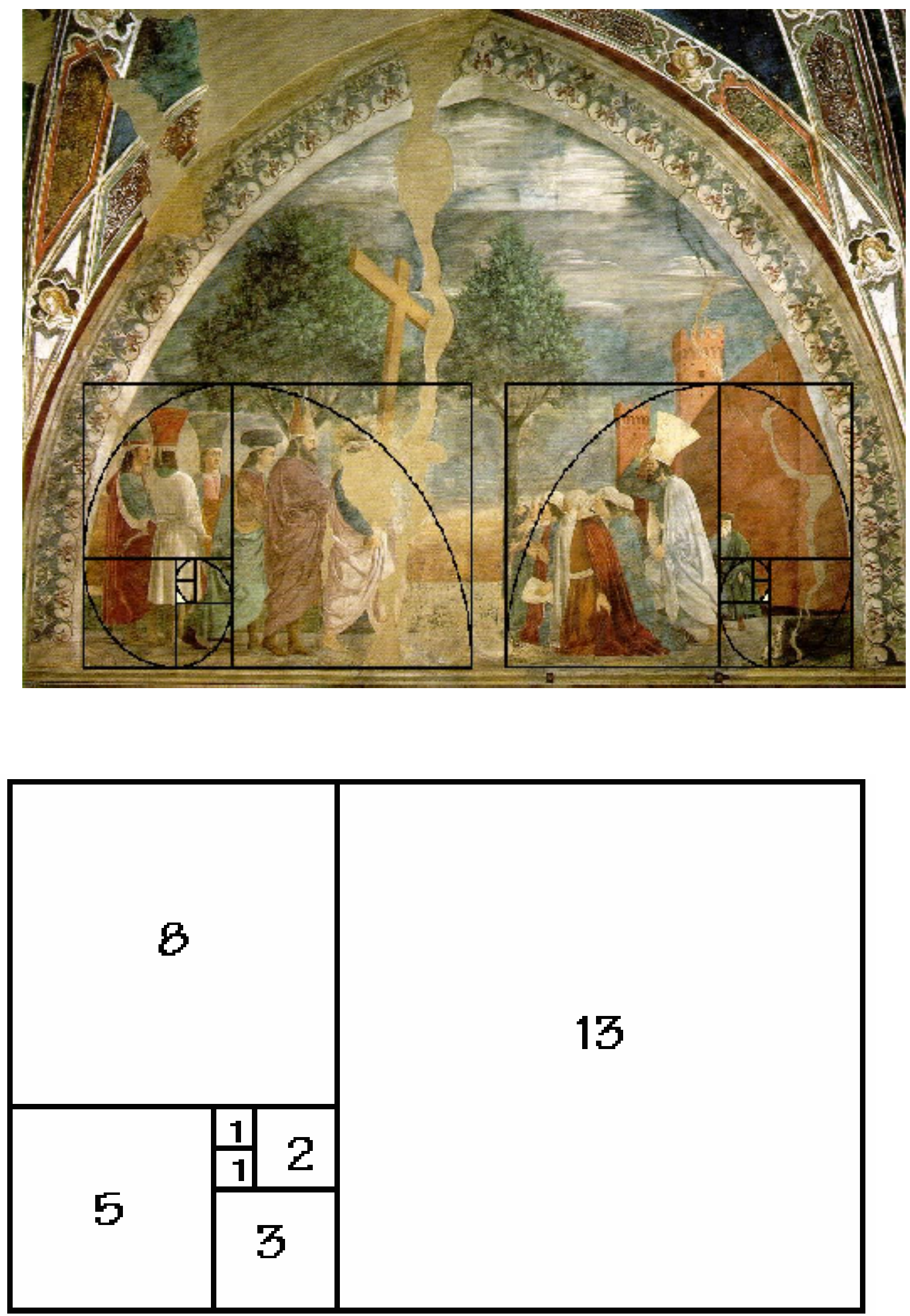


\subsubsection{Divisão de um Segmento em Partes Iguais}

Utilizando-se dois esquadros, é possível dividir um segmento retilíneo qualquer número de partes iguais. Para dividir um segmento de reta $A B$ em quatro partes iguais, por exemplo, devemos, pelo extremo $A$ traçar uma reta auxiliar $A C$, de qualquer tamanho. Nessa reta auxiliar marcaremos quatro divisões de qualquer tamanho, desde que sejam iguais entre si. A última marca ligaremos à extremidade $B$; utilizando um esquadro, traça-se retas paralelas que irão dividir $A B$ em partes iguais.
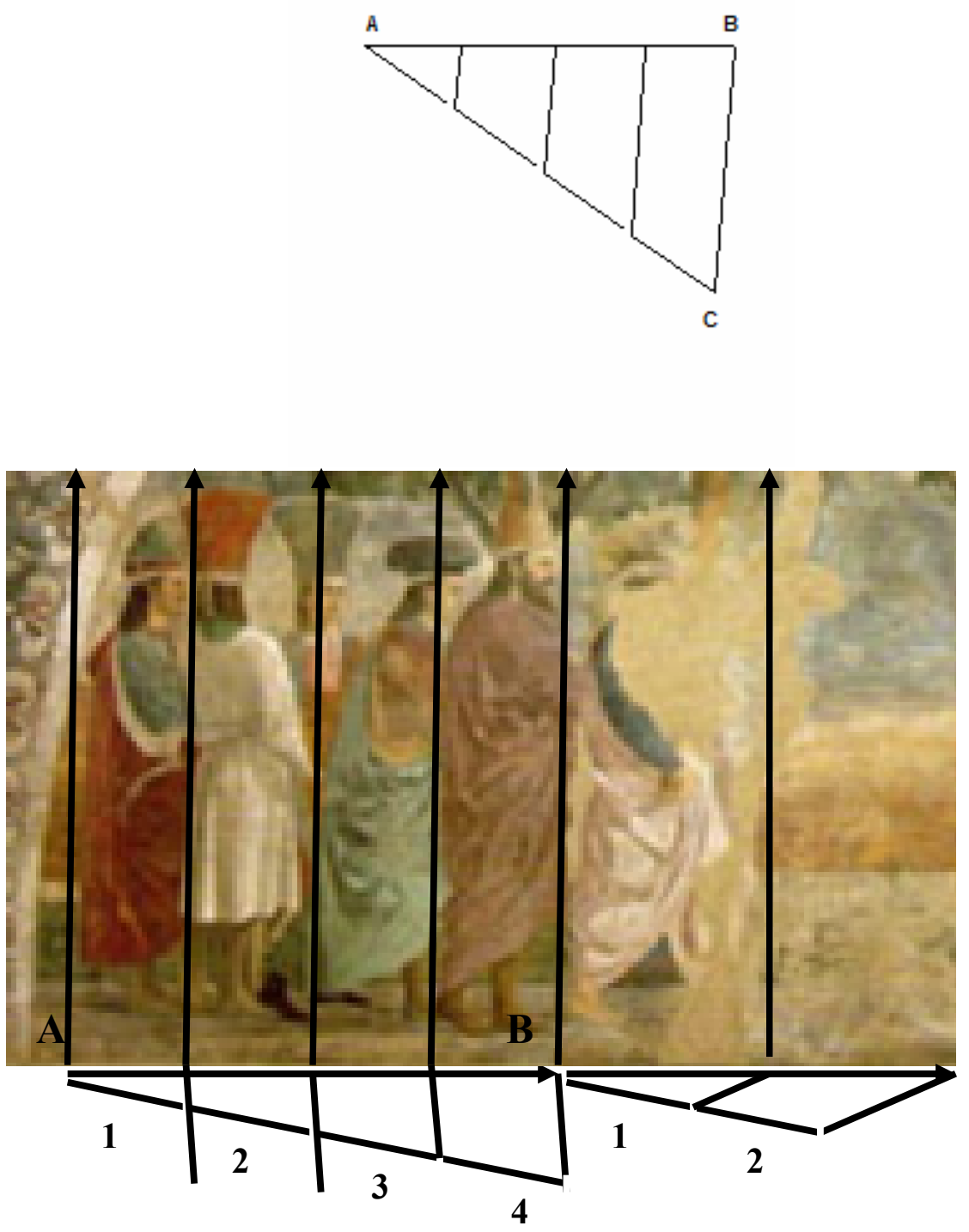

Observando o detalhe acima, podemos perceber que Piero dividiu o segmento $A B$ e quatro partes iguais para que as personagens ocupassem espaços 
iguais. O curioso é que caso optássemos por dividir a metade esquerda inteira em partes iguais (seis), a quinta reta passaria bem em cima da representação de Heráclito. Acreditamos que Piero tenha resolvido o problema da seguinte maneira: dividiu o primeiro segmento e quatro partes e o segundo e duas partes iguais. Com isso, acreditamos que Piero tenha resolvido o problema da disposição das personagens do lado esquerdo da composição.

\subsubsection{Terceira Proporcional}

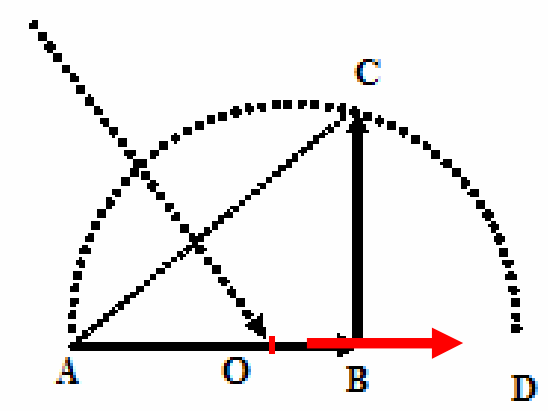

Para determinarmos a terceira proporcional entre dois segmentos, devemos, primeiramente, sobre uma linha qualquer, marcar o segmento $A B$; em seguida levanta-se uma perpendicular pelo ponto $B$, e marca-se sobre essa perpendicular o comprimento $B C$. Liga-se, agora, o ponto $C$ ao ponto $A$. Traçando uma perpendicular por $A C$, determinaremos em $A B$ o ponto $O$. Com centro em $O$ e raio $A O$ descreve-se uma semi-circunferência que vai determinar à direita de $B$, na horizontal, o ponto $D$. O segmento retilíneo $B D$ é a terceira proporcional procurada. 


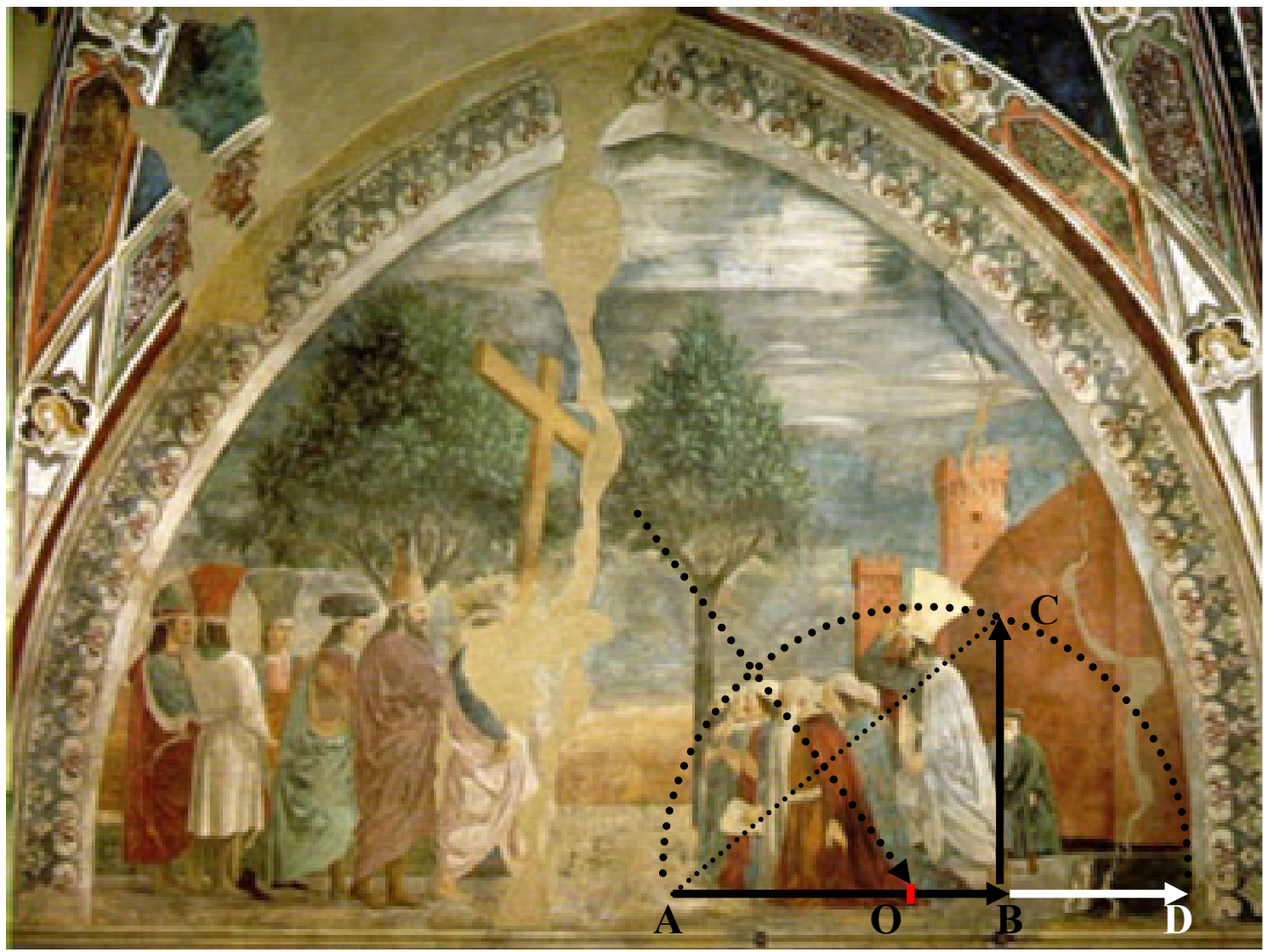

O segmento $B D$ é a terceira proporcional entre $A B$ e $B C$. 


\section{VI \\ CONCLUSÃO}

Com este trabalho procuramos entender quais foram as principais implicações que a descoberta da Geometria não-Euclidiana causaram no panorama científico e artístico a partir de 1800, época das primeiras discussões sobre o assunto. $\mathrm{O}$ impacto foi tão profundo que, no campo da Física, ajudou a redirecionar os rumos da Teoria da Relatividade Geral. Marcelo Gleiser reconhece que foi só após Einstein entender e dominar as sutilezas da Geometria não-Euclidiana que ele obteve as equações da relatividade geral em sua forma definitiva.

Para entendermos por que uma geometria teve um papel tão importante no desenvolvimento da teoria de Albert Einstein devemos entender, primeiramente, que estamos falando de uma geometria que muito se distancia da geometria dos postulados de Euclides. Linhas retas deixaram de ser a trajetória mais curta conectando dois pontos em e um espaço plano; agora os movimentos ocorrem em espaços curvos, e linhas mais curtas entre dois pontos passaram a ser curvas. Tais curvas são chamadas geodésicas. Ou seja, sobre a superfície de uma esfera podemos traçar somente curvas, e não linhas retas. De todas as curvas que conectam dois pontos, a mais curta é o arco de um grande círculo. Por conseguinte, as geodésicas sobre a superfície de uma esfera são os arcos de grandes círculos.

É por meio da geometria não-Euclidiana que os cientistas podem determinar a rota de uma espaçonave em direção a outros planetas. Logo, um dos fatores indispensáveis para o êxito de qualquer missão é saber se a natureza do espaço cósmico é euclidiana ou não-euclidiana, se o Universo é curvo ou não. Em outras palavras, qual a geometria que deve ser utilizada em viagens interestelares? Com a descoberta de que o espaço é curvo, não se deve utilizar a geometria euclidiana em hipótese alguma, pois o perigo de conduzir uma espaçonave a uma singularidade do espaço é enorme, já que a viagem ocorreria sem escalas.

Uma singularidade acontece quando a superfície de uma região atinge o tamanho zero. E a partir do momento em que a superfície da região encolhe a zero, o mesmo deve acontecer com seu volume. Toda a matéria dentro da estrela será 
comprimida em uma região de volume zero, assim a densidade da matéria e a curvatura do espaço-tempo se tornarão infinitas. O interessante é que enquanto George Friedrich Riemann, Nikolayi Ivanovich Lobachevsky e János Bolyai precisaram criar modelos de superfície de diferentes formatos para testar suas hipótese - uma delas é a pseudo-esfera, onde se encontra a possibilidade da afirmação do postulado de Lobachevsky, ou seja, que por um ponto $\mathbf{P}$ fora de uma reta $\mathbf{r}$ passa mais de uma reta paralela à reta $\mathbf{r}$ - Einstein teve de lutar com as complexidades do espaço curvo, atribuindo a quarta dimensão ao tempo e fazendo com que toda a questão desse certo.

Constatamos que uma outra proposição teórica muito instigante fez parte das discussões envolvendo alternativas à geometria Euclidiana. Além dos debates relacionados à geometria não-Euclidiana veríamos entrar em cena uma discussão relacionada à quarta dimensão. De início a quadrimensionalidade esteve envolta em todo tipo de misticismo. Na realidade, antes de Einstein criar a Teoria da Relatividade Geral, a quarta dimensão sempre foi considerada uma questão que dizia respeito ao espaço. Temos que aceitar o fato de que o tempo não é completamente separado e independente do espaço, mas que se combina com ele para formar um objeto chamado espaço-tempo. A idéia de que o tempo é algo que está intrinsecamente ligado ao espaço muito nos ajudou a entender a utilização da quarta dimensão na pintura moderna.

Percebemos que Salvador Dali, por exemplo, que cita textualmente as descobertas feiras por Einstein, e admite que pela teoria da relatividade não há nem espaço nem tempo absolutos, e que só a união do tempo e do espaço tem uma significação física, mesmo ele se volta para a quarta dimensão abordando questões puramente espaciais. Na realidade, as questões envolvendo a quadrimensionalidade tinham um fundo místico.

Ao falarmos sobre a quarta dimensão devemos ter clareza de sua natureza: se estamos nos referindo a uma quarta dimensão espacial ou a uma quarta dimensão temporal. Foi somente com a popularização da Teoria da Relatividade Geral que aparentemente passamos a ter mais segurança para lidar com tal fenômeno. O tempo passou a ser um tópico significativo e relevante, pois interfere no espaço. Não devemos acreditar, no entanto, que a quarta dimensão é apenas a inclusão de uma quarta variável $t$ às três variáveis de espaço $x, y, z$, ou seja, simplesmente acrescentar o tempo à altura, à largura e ao comprimento. Trata-se de 
um termo muito restrito! Existe uma significação real e bem precisa que ultrapassa a simples idéia de uma quarta variável. O termo dimensão, na realidade, está ligado a uma idéia de ordem. A ordem dos eventos na natureza segue uma ordem quadrimensional indissolúvel.

Ficou evidente que as investigações relacionadas à quarta dimensão sempre estiveram ligadas ao espaço e nunca ao tempo. Einstein, criando o espaço-tempo, cremos, enterraria de vez a quarta dimensão como um problema espacial. $\mathrm{O}$ artigo de Gimmell só confirma nossa hipótese, pois os artista que se envolveram com a quarta dimensão nunca a associaram ao tempo. Gimmell observa que muitos historiadores da arte tentam estabelecer relações entre a Teoria da Relatividade e a parte teórica do movimento Cubista. Nenhum deles observou que, na realidade, nunca houve contato entre os dois campos, assim como há diferenças marcantes tanto na literatura científica quanto na teorização cubista. A idéia de que as imagens fragmentadas das pinturas cubistas de alguma maneira incorporaram os elementos das equações de Einstein e, em função desta incorporação, conseguiram fazer com que as pessoas mudassem seu modo de pensar o espaço é, de acordo com Gimmell, questionável.

Acreditamos que sem conceber a quarta dimensão como temporal, nenhum artista de fato estará explorando a quarta dimensão. 
Bibliografia

Angelini, Alessandro. Piero della Francesca; Traduccion de Martha Canfield Milan: Scala/Riverside, 1991.

Atalay, Bulent. A Matemática e a Mona Lisa: a confluência da arte com a ciência. Tradução: Mário Vilela; São Paulo - Mercuryo, 2007.

Barbosa, Ruy Madsen. Descobrindo a Geometria Fractal para a sala de aula; Belo Horizonte - Autêntica, 2005, $2^{a}$ edição.

Barret, Edward and Marie Redmond. Contextual Media - MIT Pres, Cambridge, Massachusetts, London, 1997.

Baxandall, Michael. Pintura y vida cotidiana en el Renascimiento: Arte y experiencia en el Quattrocento. Versión castellana: Homero Alsina Thevenet; Barcelona - Editorial Gustavo Gili S. A., 1981.

- Padrões de Intenção: a explicação histórica dos quadros. Tradução: Vera Maria Pereira; São Paulo - Companhia das Letras, 2006.

Bodanis, David. $E=m c^{2}$ : uma biografia da equação que mudou o mundo e o que ela significa; tradução: Vera de Paula Assis; Rio de Janeiro — Ediouro, 2001.

Boyer, Carl B. História da Matemática. Tradução: Elza F. Gomide; São Paulo — Editora Edgar Blücher, 1996, 2ª edição.

Bowness, Alan. Modern European Art; London — Thames and Hudson, 1997.

Briggs, John. Fractals: The Patterns of Chaos and Discovering a New Aesthetic of Art, Science, and Nature; London - Thames and Hudson, 1992.

Burke, William, L. Spacetime, Geometry, Cosmology - University of Califórnia, Santa Cruz, 1980.

Cavalcanti, Carlos. Como Entender a Pintura Moderna; Rio de Janeiro - Editora Civilização Brasileira S. A., 1963.

Chipp, Herschel B. Teories of Modern Art: A Source Book by Artists and Critics; Califórnia - University of California Press, 1968.

Clark, Kenneth. Piero della Francesca. Phidon Press Limited - London, 1951.

- The Romantic Rebellion: Romantic versus Classic Art; New York - Harper \& Row, Publishers, 1973.

Colérus, Egmont. Du point à la quatrième dimension ou La Géométrie pour tous; traduit de l'Allemand par J. du Plessis de Grenédan — Paris: Flammarion, Éditeur, 1957. 
Couchot, Edmond. A Tecnologia na arte: da fotografia à realidade virtual; tradução: Sandra Rey - Porto Alegre: Editora da UFRGS, 2003.

Coutinho, Lázaro. Convite às Geometrias Não-Euclidianas - Rio de Janeiro: Editora Interciência, 2001.

Dali, Salvador. Oui 2. L'archangélisme Scientifique; Paris — Denoël/Gonthier, 1971.

Domingues, Diana (org.). A Arte no Século XXI: a humanização das tecnologia. São Paulo: Fundação Editora da UNESP, 1997.

Duchamp, Marcel. Duchamp du Signe: Ecrits; Paris - Champs Flamarion, 1994.

Eddington. A. S. Espace, Temps et Gravitation. Traduit de l'anglais par J. Rossignol; Paris - Librairie Scientifique J. Hermann, 1921.

Faber, Richard L. Foundations of Euclidean and Non-Euclidean Geometry; New York - Marcel Dekker, INC, 1983.

Ferris, Timothy. O Despertar na Via Láctea: Uma História da Astronomia; tradução: Waltensir Dutra; Rio de Janeiro - Editora Campos, 1990.

Field. J. V. Piero della Francesca. A Mathematician's Art; New Haven and London Yale University Press, 2005.

Focillon, Henri. Piero della Francesca. Presses Pocket - Baltrusaïtis, 1991.

França, Lilian Cristina Monteiro. Da Geometria Euclidiana à Geometria Fractal - Um estudo sobre história da arte in "Forma e Ciência"; São Paulo - Educ, 1995.

Gerard, Max. Dali. Tradução: Maria Cristina Vidal Borba; São Paulo — Edições Siciliano, 1987.

Giannetti, Claudia. Estética Digital: Sintopia del arte, la ciência y la tecnologia Barcelona: Associació de Cultura Contemporània L'Angelot, 2002.

Gimmell, Jennifer. A Clarification of Einstein's Theory of Relativity and the fourdimensionality of cubism in the early Twentieth Century, November 04, 2002 in www.pas.rochester.edu/ iennifer/Final\%20paper.doc; acesso em 21 de abril de 2008.

Ginzburg, Carlo. Indagações sobre Piero. Tradução: Luiz Carlos Cappellano; São Paulo - Paz e Terra, 1989.

Gleiser, Marcelo. A Dança do Universo: Dos Mitos de Criação ao Big-Bang; São Paulo - Companhia das Letras, 1998, $2^{a}$ edição. 
Gould, Stephen Jay. Henri Poincaré: The Value of Science; New York - The Modern Library, 2001.

Greenberg, Marvin Jay. Euclidian and Non-Euclidian Geometries: Development and History; W. H. Freeman and Company - 1993, third edition.

Gurevich, L. E. A. D. Chernin. The Magic of Galaxies and Star. Translated form Russian by Machael Borov; Moscow — Mir Publishers, 1987.

Hawking, Stephen W. A Brief History of Time: from the Big Bang to Black Holes; New York - Bantam Books, 1988.

. Breve História do Tempo Ilustrada. Tradução: Clara Allain; Curitiba Editora Albert Einstein Ltda, 1997.

Heilbron, J. L. Geometry civilized: history, culture, and technique. New York Oxford University Press, 2003.

Henderson, Linda Dalrymple. The Fourth Dimension and non-Euclidean Geometry in Modern Art; New Jersey —Princeton University, 1983.

—. Duchamp in Context; New Jersey — Princeton University Press, 1998.

Ifrah, Georges. From one to zero: a universal history of numbers. Translated by Lowell Bair - New York, NY, U.S.A.: Penguim Books, 1985.

- História Universal dos Algarismos. Tradução: Alberto Muñoz e Ana Beatriz Katinsky - São Paulo: Editora Nova Fronteira, 1997.

- Os Números: História de uma Grande Invenção; tradução: Stella Maria de Freitas Senra - São Paulo: Globo, 9ª edição, 1998.

Janson, Horst Woldemar. História da Arte. Tradução: J. A. Ferreira de Almeida, Maria Manuela Rocheta Santos; Lisboa - Fundação Calouste Gulbenkian, 1989.

Kubrusly, Ricardo S. Geometrias não-Euclidianas: Uma breve introdução às Geometrias Hiperbólicas in http://www.dmm.im.ufri.br/projeto/diversos/gne.htm/\#pseudoesfera. Acesso em 24/03/2008.

Lacan, Jacques. Da Psicose Paranóica em suas relações com a Personalidade. Tradução: Aluisio Menezes, Marco Antonio Coutinho Jorge, Potiguara Mendes da Silveira Jr.; Rio de Janeiro — Forense Universitária, 1987.

Lavin, Marilyn Aronberg. Piero della Francesca; London - Phaidon Press Limited, 2002. 
Levy, P. As Tecnologias da Inteligência: O futuro do pensamento na era da informática. Tradução: Carlos Irineu da Costa - Rio de Janeiro: Ed. 34, 1993, (coleção TRANS).

. O que é virtual. Tradução: Paulo Neves - Rio de Janeiro: Ed. 34, 1996, (coleção TRANS).

Longhi, Roberto. Piero della Francesca. Traduit de l'italien par Pierre Léglise-Costa,

Lunenfeld, P. The Digital Dialect: new essays on new media; Cambridge, MIT Press, 1999.

McLuhan, Marshall. Os Meio de Comunicação como Extensões do Homem. Tradução: Décio Pignatari; São Paulo - Editora Cultrix, s.d.

Martin, George E. The Foundation of Geometry and the Non-Euclidean Plane Springer-Verlag, New York, 1975.

Matuck, Arthur. O Potencial Dialógico da Televisão: Comunicação e Arte na Perspectiva do Receptor. São Paulo: ANNABLUME: ECA-USP, 1995.

Mèredieu, Florence de. Arts et Nouvelles Technologies: Art Vidéo, Art Numérique Larouse, 2005.

Negroponte, N. Being Digital. London: CORONET BOOKS - Holder and Stoughton, 1996.

Noronha, M. Helena. Euclidean and Non-Euclidean Geometries - Prentice Hall, Upper Saddle River, New Jersey, 2002.

Nottale, Laurent. Fractal Space-Time and Microphysics: Toward a Theory of Scale Relativity; London — World Scientific, 1992.

Ostrower, Fayga. A Sensibilidade do Intelecto - Editora Campos; Rio de Janeiro: 1998, $2^{a}$ edição.

Packer, R. and Jordan, K. (ed.). Multimedia: from Wagner to virtual reality. W.W. Norton \& Company Ltd., 2001.

Panofsky, Erwin. Renascimento e Renascimentos na Arte Ocidental; tradução: Fernando Neves - Editora Presença, Ltda, Lisboa, 1981.

Pedoe, Dan. La Geometria en el Arte; versión castellana: Caroline Phipps Editorial Gustavo Gilli S.A.; Barcelona, 1982, 2ª edição.

Peitgen, Heinz-Otto, Dietmar Saupe (editors). The Science of Fractal Images; New York - Springer-Verlag, 1988.

Penrose, Roger. The Emperor's New Mind: Concerning Computers, Minds, and The Laws of Physics. London: Vintage, 1990.

Poincaré, Henri. A Ciência e a Hipótese; tradução: Maria Auxiliadora Kneipp; Brasília — Editora Universidade de Brasília, 1988. 
Pool, Ithiel de Sola. Technologies without Boundaries: on Telecommunications in a Global Age - Cambridge, Massachusetts, 1990.

Science and Method; translated by Francis Maitland - Dover Publications,

INC, USA, sd.

Sagan, Carl. Bilhões e Bilhões: Reflexões sobre vida e morte na virada do milênio. Tradução: Rosaura Eichemberg - São Paulo: Companhia das Letras, 1998.

Santaella, Maria Lucia. Cultura das Mídias. São Paulo: Razão Social, 1992.

Matrizes da Linguagem e Pensamento: sonora, visual e verbal. São Paulo: Editora lluminuras, 2001.

Cultura e artes do pós-humano: da cultura das mídias à cibercultura. São

Paulo: Paulus, 2003.

Schwars, Arturo. Marcel Duchamp. Fundação Bienal de São Paulo, 1987.

Sevcenko, Nicolau. O Renascimento; Campinas - Editora da Universidade Estadual de Campinas, 1988.

Venturi, Lionello. Piero della Francesca. Traduit de l'italien par Rosabianca SkiraVentury,

Wertheim, Margaret. Uma História do Espaço: de Dante à Internet; tradução: Maria

Luiza X. de A. Borges; Rio de Janeiro - Jorge Zahar Editores, 2001.

\footnotetext{
${ }^{1}$ Pierre Lévy afirma que o Trívio constituía a base do ensino liberal também da Antigüidade; portanto, não somente da Idade Média (1996, p. 81). Mas, na realidade, na busca pela lei eterna do Universo, os seguidores da Escola de Pitágoras consideravam quatro graus de sabedoria: Aritmética, Astronomia, Geometria e Música. Eles, porém, não denominavam esses quatro graus de Quadrívio, como na Idade Média. E nem fizeram referência a três graus anteriores de sabedoria, a um suposto Trívio.

2 "Pitágoras não apreciava o isolamento e acabou subornando um menino para ser seu primeiro aluno. A identidade do garoto é incerta, mas alguns historiadores sugerem que ele também se chamaria Pitágoras e que o estudante mais tarde ficaria famoso ao sugerir que os atletas deveriam comer carne para melhoria da constituição física. Pitágoras, o mestre, pagava ao seu aluno três ébolos para cada aula a que ele comparecia. Logo percebeu que, à medida que as semanas se passavam, a relutância inicial do menino em aprender se transformava em entusiasmo pelo conhecimento. Para testar seu pupilo, Pitágoras fingiu que não podia mais pagar o estudante e que teria que interromper as aulas. Então o menino se ofereceu para pagar por sua educação. O pupilo tornara-se discípulo. Infelizmente este foi o único adepto que Pitágoras conquistou em Samos. Ele chegou a estabelecer temporariamente uma escola conhecida como o Semicírculo de Pitágoras, mas suas idéias de reforma social eram inaceitáveis e o filósofo foi obrigado a fugir com sua mãe e seu único discípulo" (Singh: 1998, p. 30).

3 As idéias de Pitágoras suscitaram importantes descobertas matemáticas, mas a mais curiosa está intimamente ligada ao último Teorema de Fermat. Como podemos facilmente notar, na equação de Pitágoras todos os números são elevados ao quadrado. Segundo Singh, Eric Temple Bell, em seu livro $O$ último problema, descrevia uma equação parecida na qual os números foram elevados ao cubo. Eis o problema: encontrar trios de números inteiros que satisfizessem a equação cúbica. Parece não existir trios de números inteiros para tal equação! $\mathrm{O}$ fato é que Fermat, um dos matemáticos mais brilhantes e intrigantes da história, não verificou, na verdade, a infinidade de números para se certificar de que não existiam combinações para solucionar a equação, exatamente o que aconteceu com Pitágoras, ou seja, Pitágoras não precisou checar todos os triângulos retângulos para demonstrar a validade de seu teorema; portanto, Fermat não precisou testar todos os números para demonstrar a validade do seu. $\mathrm{O}$ último Teorema de Fermat declara que
} 


$$
\mathrm{x}^{\mathrm{n}}+\mathrm{y}^{\mathrm{n}}=\mathrm{z}^{\mathrm{n}}
$$

e que não tem solução no campo dos números inteiros para $n$ maior que 2. O fato é que Fermat, enquanto estudava o Livro II da Aritmética de Euclides, ficou impressionado pela infinidade de trios pitagóricos existentes. Segundo Singh, Fermat deve ter olhado a exposição detalhada que Diofante fazia dos trios pitagóricos e pensou numa maneira de acrescentar alguma coisa àquele assunto. "Enquanto olhava para a página, ele começou a brincar com a equação de Pitágoras, tentando descobrir alguma coisa que escapara à atenção dos gregos" (Singh: 1998, p. 79). Como destaca Singh, num momento de total genialidade - que o imortalizaria -, Fermat criou uma equação que, embora muito semelhante à de Pitágoras, não traria nenhuma solução. No lugar da equação de Pitágoras,

$$
x^{2}+y^{2}=z^{2}
$$

Fermat propôs a seguinte variante:

$$
x^{3}+y^{3}=z^{3}
$$

Esta "simples" mudança foi suficiente para manter, por mais de 300 anos, muitos matemáticos brilhantes ocupados, tentando provar seu teorema. "Ao meramente trocar o dois da equação de Pitágoras por qualquer número maior, a busca por soluções para números inteiros deixa de ser um problema relativamente simples e se torna um desafio impossível. De fato, o grande matemático francês do século XVII, Pierre de Fermat, fez a espantosa afirmação de que não existiriam soluções para esta equação" (Singh: 1998, p. 51). De acordo com Singh, Fermat chegou a elaborar uma demonstração "realmente maravilhosa" para tal proposição que, no entanto, não coube na margem do livro que ele analisava. Andrew Wiles, apesar do peso de mais de 300 anos de tentativas infrutíferas, tomou para si a responsabilidade de demonstrar tal teorema. Começaria, assim, uma verdadeira batalha em completo isolamento e segredo, pois se tratava do desafio mais importante de sua vida. Isso porque a demonstração do Último Teorema de Fermat, como sustenta Singh, é um assunto que talvez apenas uma meia dúzia de pessoas no mundo todo poderia compreender completamente. Após sete anos de estudos e pesquisas intensas, em 23 de junho de 1993, Wiles finalmente demonstrou o Último Teorema de Fermat. "A demonstração era um argumento gigantesco, construído de um modo intrincado a partir de centenas de cálculos matemáticos grudados por milhares de elos lógicos" (Singh: 1998, p. 260).

${ }^{4}$ Singh explica que, apesar de este teorema estar intimamente associado ao nome de Pitágoras, na verdade ele já era usado pelos chineses e pelos babilônios mil anos antes. A novidade está no fato de que estas culturas não sabiam que o teorema era verdadeiro para todos os triângulos retângulos. "Era verdadeiro para os triângulos que tinham testado, mas eles não tinham meios de demonstrar que era verdadeiro para os triângulos que ainda não tinham testado. O motivo pelo qual o teorema leva o nome de Pitágoras é que foi ele o primeiro a demonstrar esta verdade universal" (Singh: 1998, p. 40).

${ }^{5}$ http://www.dmm.im.ufri.br/projeto/diversos/gne.html\#pseudoesfera. Acesso em 24/03/2008.

6 "No passado, para os cosmólogos, SINGULARIDADE OU BURACO NEGRO significavam a mesma coisa. Modernamente já se sabe que são coisas distintas. Singularidade é uma "dobra" no espaço, ou seja, considerando que o espaço é uma superfície, uma singularidade nessa superfície é um ponto diferente dos demais. É um ponto singular, no qual tudo pode acontecer. A bem da verdade, os cientistas não sabiam muito a respeito de uma singularidade, a não ser que se tratava de um ponto a ser evitado em uma viagem pelo espaço" (Coutinho: 2001, p. 18).

${ }^{7}$ Traceria é um trabalho decorativo feito na pedra a partir de elementos geométricos

${ }^{8}$ Lembremos que o um polígono é um quadrado inscrito em um círculo imaginário.

${ }^{9}$ No espaço isótropo todas as retas que passam por um mesmo ponto são idênticas umas às outras.

${ }^{10}$ Segundo consta no livro de Wertheim (2001, p. 152), Kaluza, um matemático da Universidade de Königsberg (hoje Kaliningrado), reescreveu as equações da relatividade geral a fim de demonstrar que a força eletromagnética, responsável pela eletricidade, o magnetismo e a luz, podia ser o resultado da curvatura num espaço hiperdimensional. Com tal atitude, Kaluza abriria caminho para que se considerasse o eletromagnetismo como uma forma de gravidade. Mas a gravidade de uma quinta dimensão invisível do espaço. As idéias de Kaluza sobre ma quinta dimensão suscitaram, com diz Wertheim, uma pergunta incômoda: quantas dimensões de espaço existem à nossa volta? Na década de 1980 os cientistas, com o intuito de demonstrar que há uma força que mantém unida a gravidade, o eletromagnetismo, a força nuclear fraca e a força nuclear forte, aventaram a possibilidade de minúsculas dimensões adicionais. Conforme relata Wertheim, para acomodar a força fraca e forte os físicos descobriram que tinham que acrescentar mais seis dimensões ao espaço. Portanto, o espaço passou a ter onze dimensões possíveis. Enfim, "O quadro que emergiu ao longo da última década é, portanto, o de um universo de onze dimensões, com as quatro grandes dimensões remanescentes (três de espaço e uma de 
tempo), e sete microscópicas dimensões de espaço, todas enroscadas em alguma minúscula e complexa forma geométrica. Na escala que nós, seres humanos, experimentamos, o mundo é quadrimensional, mas sob ele, dizem esse novos físicos de "hiperespaço", a "verdadeira" realidade tem onze dimensões. (Ou talvez, segundo algumas das teorias mais recentes, dez)" (Wertheim: 2001, p. 155).

${ }^{11}$ From Scientific Romances, Vol. 1(1884). Copy-text: pp. 1-22, Speculation on the Fourth Dimension, Selected Writings of Charles H. Hinton, Copyright 1980 by Dover Publication, Inc., ISBN 0-486-23916-0, LC 79-54399.

12 http://www.niteroiartes.com.br/cursos/la e ca/trecho3.html. Trecho de livro Arte Moderna de Guilio Carlo Argan.

${ }^{13}$ Idem.

14 Idem.

${ }^{15}$ Os imensamente ricos eram milionários. A população da Terra na época de Jesus consistia talvez em 250 milhões de pessoas. Havia quase 4 milhões de norte-americanos na época da Convenção Constituinte de 1787; no início da Segunda Guerra Mundial, havia 132 milhões. Existem 93 milhões de milhas (150 milhões de quilômetros) da Terra até o Sol. Aproximadamente 40 milhões de pessoas foram mortas na Primeira Guerra Mundial; 60 milhões na Segunda Guerra Mundial. Há 31,7 milhões de segundos num ano (como é bastante fácil verificar). Os arsenais nucleares globais no fim da década de 80 continham um poder explosivo suficiente para destruir 1 milhão de Hiroshimas. Para muitos fins e por um longo tempo, o "milhão" era a quintessência dos números grandes (Sagan: 1998, p. 12).

${ }^{16}$ Os gastos militares mundiais são, hoje em dia, de quase US\$ 1 trilhão por ano. O endividamento total de todas as nações subdesenvolvidas para com os bancos ocidentais está chegando aos US\$ 2 trilhões (era cerca de US\$ 60 bilhões em 1970). O orçamento anual do governo dos Estados Unidos também se aproxima de US\$ 2 trilhões. A dívida nacional é cerca de US\$ 5 trilhões. A estimativa de custo do plano tecnicamente duvidoso da Guerra nas Estrelas na era Reagan ficava entre US\$ 1 trilhão e US\$ 2 trilhões. Todas as plantas na Terra pesam um trilhão de toneladas. As estrelas e os trilhões têm uma afinidade natural: a distância do nosso sistema solar até a estrela mais próxima, a Alfa do Centauro, é de 25 trilhões de milhas (cerca de 40 trilhões de quilômetros) (SAGAN, 1998, p. 14).

${ }^{17}$ Você escreve o número 10; depois um número pequeno, alçado à direita do 10 como um sobrescrito, informa quantos zeros existem depois do número 1 . Assim, $10^{6}=1.000 .000 ; 10^{9}=1.000 .000 .000 ; 10^{12}=$ 1.000.000.000.000; e assim por diante. Esses pequenos sobrescritos são chamados expoentes ou potências; por exemplo, $10^{9}$ é descrito como "10 elevado à potência" ou, equivalentemente, "10 elevado à nona" (à exceção de $10^{2}$ e $10^{3}$, que são chamados "10 ao quadrado" e "10 ao cubo", respectivamente). Essa expressão, à potência" como "parâmetro" e vários outros termos científicos e matemáticos -, está entrando na linguagem de todos os dias, mas com o significado cada vez mais obscuro e distorcido (Sagan: 1998, p. 15).

${ }_{18} 1.000 .000 .000 .000 .000$ (quatrilhão) - 23 milhões de anos (mais tempo do que a existência de humanos sobre a Terra); 1.000.000.000.000.000.000 (quintilhão) - 32 bilhões de anos (mais tempo do que a idade do universo (Sagan: 1998, p. 18).

${ }^{19} \mathrm{O}$ algoritmo de Euclides, sem utilizar a fatoração, encontra o máximo divisor comum entre dois números diferentes de zero. Por exemplo, tomando-se os números 348 e 156 teremos o seguinte:

dividendo -348

divisor -156

resto $(348 / 156)=36$

Como 36 é diferente de zero, substituímos o dividendo e o divisor, e repetimos o passo anterior:

dividendo -156

divisor -36

resto $(156 / 36)=12$

Repetimos o passo anterior:

dividendo -36

divisor -12

resto -0

Como 36 dividido por 12 é igual a 0, o máximo divisor comum de 348 e 156 é 12 . 
